Founder: Federal Scientific Center for Medical and Preventive

Health Risk Management

Technologies Federal Service

for Surveillance on Consumer

Rights Protection and

Human Wellbeing

\section{Contact Information:}

82 Monastyrskaya St.,

Perm, 614045, Russia

Tel/Fax: + 7 (342) 237-25-34

E-mail: journal@fcrisk.ru

Site: journal.fcrisk.ru/eng

Editor and corrector - M.N. Afanaseva Technical Editor - A.A. Nizhegorodova Translators - N.V. Dubrovskaya, N.A. Tregubova

All rights reserved. No part of this publication may be stored in the computer's memory or reproduced in any way without the prior written permission of the publisher.

The publication 30.12.2018.

Format $90 \times 60 / 8$.

Order No. $285 / 2018$.

Edition is 500 copies.

The price is free.

The Journal is registered by The Federal Service For Supervision Of Communications, Information Technology, And Mass Media (Roscomnadzor). Register certificate СМИ - ПИ No. ФС 77-52552

issued on January 21, 2013

Address of the publisher and printing house:

29 Komsomolsky ave., Perm, 614990,

Russia, tel.: +7 (342) 219-80-33

Printed by the Publishing House of Perm National Research Polytechnic University (29 Komsomolsky ave., Perm, 614990, Russia, tel.: +7 (342) 219-80-33)

\section{Subscription number: catalog "Russian Post" ("Interregional subscription agency") 04153}

ISSN (Print) 2308-1155

ISSN (Online) 2308-1163

ISSN (Eng-online) 2542-2308

The edition is granted the financial support by the Perm Regional Ministry for Educational and Science

\section{HEALTH RISK ANALYSIS}

Theoretical and practical journal. Start of publication: 2013.

4 issues per year

\section{EDITORIAL BOARD}

G.G. Onishchenko - Editor in Chief, Fellow of the Russian Academy of Sciences, DSc, Professor (Moscow, Russia) N.V. Zaitseva - Deputy Chief Editor, Fellow of the Russian Academy of Sciences, DSc, Professor (Perm, Russia) I.V. May - Executive Secretary, DSc, Professor (Perm, Russia)

\section{EDITORS}

S.L. Avaliani - DSc, Professor (Moscow, Russia)

A.B. Bakirov - DSc, Professor (Ufa, Russia)

E.N. Belyaev - corresponding member of RAS, DSc, Professor (Moscow, Russia)

V.M. Boev - DSc, Professor, (Orenburg, Russia)

I.V. Bragina -DSc (Moscow, Russia)

R.V. Buzinov - DSc (Arkhangelsk, Russia)

I.V. Bukhtiyarov - corresponding member of RAS, DSc,

Professor (Moscow, Russia)

V.B. Gurvich - DSc (Ekaterinburg, Russia)

I. Dardynskaia - DSc, Professor (Chicago, USA)

MA. Zemlyanova - DSc (Perm, Russia)

U.I. Kenesariev - DSc, Professor, corresponding member of the Academy of Medical Sciences of Kazakstan (Almaty, Kazakstan)

T. Cronberg - DSc in Ec., DSc in Tec., Member of the European Parliament from Finland. (Ruveslahti, Finland) S.V. Kuz'min - DSc, Professor (Ekaterinburg, Russia)

V.V. Kutyrev - Fellow of the Russian Academy of Sciences, DSc, Professor (Saratov, Russia)

V.R. Kuchma - corresponding member of RAS, DSc, Professor, (Moscow, Russia)

A.V. Mel'tser - DSc, Professor (St.-Petersburg, Russia)

A.Ya. Perevalov - DSc, Professor (Perm, Russia)

Y.P. Pivovarov - Fellow of RAS, DSc, Professor (Moscow, Russia)

A.Yu. Popova - DSc, Professor (Moscow, Russia)

V.N. Rakitskiy - Fellow of RAS, DSc, Professor, (Moscow, Russia)

S.I. Savelyev - DSc, Professor (Lipetsk, Russia)

P. Spencer - PhD, FRCPath Professor Department of neurology

(Portland, USA)

V.F. Spirin - DSc, Professor (Saratov, Russia) Director

A.Tsakalof - Professor of Medical Chemistry (Larissa, Greece)

V.A. Tutelyan - Fellow ofRAS, DSc, Professor (Moscow, Russia)

H.H. Hamidulina - DSc, professor, (Moscow, Russia)

V.A. Horoshavin - DSc, professor, (Perm, Russia)

S.A. Hotimchenko - DSc, professor (Moscow, Russia)

L.M. Shevchuk - PhD (Minsk, Belarus)

N.V. Shestopalov - DSc, Professor (Moscow, Russia)

P.Z. Shur - DSc, professor (Perm, Russia)
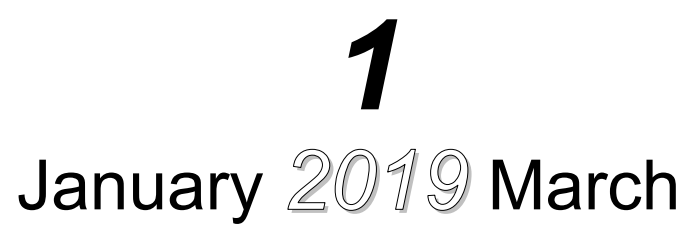


\section{CONTENTS}

\section{PREVENTIVE HEALTHCARE: TOPICAL ISSUES OF HEALTH RISK ANALYSIS}

I.V. Gaevskiy, N.V. Zaitseva, I.V. May, S.T. Karymbaeva, S.I. Sychik, E.V. Fedorenko ON METHODICAL SUPPORT FOR RISK-ORIENTED SURVEILLANCE OVER CONSUMER PRODUCTS SAFETY ON THE UNIFIED ECONOMIC TERRITORY OF THE EURASIAN ECONOMIC UNION

\section{HEALTH RISK ANALYSIS IN HYGIENE}

P.V. Trusov, N.V. Zaitseva, V.M. Chigvintsev ASSESSING RISKS OF ADVERSE CLINICAL COURSE AND OUTCOME OF AN INFECTIOUS DISEASE WITH MATHEMATICAL MODELING OF EXPOSURE TO ENVIRONMENTAL FACTORS ON THE EXAMPLE OF ALUMINUM OXIDE

S.F. Sosnina, N.R. Kabirova, M.E. Sokolnikov, P.V. Okatenko THE RISK OF ONCOHEMATOLOGICAL PATHOLOGY IN CHILDREN OF WORKERS EMPLOYED AT RADIATION HAZARDOUS PRODUCTION

G.V. Zhuntova, E.S. Grigor'eva, T.V. Azizova RISK OF MORBIDITY WITH STOMACH CANCER AMONG WORKERS EMPLOYED AT RADIATION HAZARDOUS ENTERPRISE

T.A. Novikova, Yu.A. Aleshina, A.N. Danilov, V.F. Spirin CONTEMPORARY WORKING CONDITIONS AND ASSESSMENT OF OCCUPATIONAL HEALTH RISK FOR WORKERS EMPLOYED AT FLOUR-GRINDING PRODUCTIONS

E.V. Phedorenko, N.D. Kolomiets, T.V. Mokhort, A.N. Volchenko, E.G. Mokhort, S.V. Petrenko, S.I. Sychik RISK COMMUNICATION AS A COMPONENT THAT PROVIDES STABILITY OF STRATEGY AIMED AT ELIMINATING DISEASES CAUSED BY IODINE DEFICIENCY IN BELARUS

HEALTH RISK ANALYSIS IN EPIDEMIOLOGY

V.A. Mishchenko, O.V. Ladygin, I.P. Bykov, J.A. Zakharova, A.G. Sergeev, I.A. Kshnyasev MORBIDITY WITH TICK-BORNE VIRAL ENCEPHALITIS IN SOME REGIONS IN URALSKIY FEDERAL DISTRICT WITH PREDICTIVE ESTIMATE OF SHORT-TERM EPIDEMIOLOGIC SITUATION

E.V. Kuklev, A.A. Kovalevskaya, B.L. Agapov, S.A. Scherbakova ASSESSMENT OF POTENTIAL EPIDEMIC HAZARDS CAUSED BY COMBINED FOCI WITH BACTERIAL, VIRAL AND RICKETSIAL INFECTIONS

N.V. Shestopalov, A. Yu. Skopin, L.S. Fedorova, T.V. Gololobova DEVELOPING METHODICAL APPROACHES TO MANAGING RISKS OF AIRBORNE INFECTIONS WITH AEROSOL CONTAGION
ПРОФИЛАКТИЧЕСКАЯ МЕДИЦИНА: АКТУАЛЬНЫЕ АСПЕКТЫ АНАЛИЗА РИСКА ЗДОРОВЬЮ

4 И.В. Гаевский, Н.В. Зайцева, И.В. Май, С.Т. Карымбаева, С.И. Сычик, Е.В. Федоренко К ВОПРОСУ ОБ ОБЕСПЕЧЕНИИ РИСК-ОРИЕНТИРОВАННОГО НАДЗОРА ЗА БЕЗОПАСНОСТЬЮ ПОТРЕБИТЕЛЬСКОЙ ПРОДУКЦИИ НА ЕДИНОМ ЭКОНОМИЧЕСКОМ ПРОСТРАНСТВЕ ЕВРАЗИЙСКОГО ЭКОНОМИЧЕСКОГО СОЮЗА

\section{АНАЛИЗ РИСКА ЗДОРОВЬЮ В ГИГИЕНЕ}

17 П.В. Трусов, Н.В. Зайцева, В.М. Чигвинцеев ОЦЕНКА РИСКА НЕБЛАГОПРИЯТНОГО ТЕЧЕНИЯ И ИСХОДА ИНФЕКЦИОННОГО ЗАБОЛЕВАНИЯ ПРИ ВОЗДЕЙСТВИИ ФАКТОРОВ СРЕДЫ ОБИТАНИЯ НА ОСНОВНЫЕ ЭЛЕМЕНТЫ ИММУННОЙ СИСТЕМЫ (НА ПРИМЕРЕ ОКСИДА АЛЮМИНИЯ)

30 С.Ф. Соснина, Н.Р. Кабирова, М.Э. Сокольников, П.В. Окатенко РИСК ОНКОГЕМАТОЛОГИЧЕСКОЙ ПАТОЛОГИИ У ДЕТЕЙ ПЕРСОНАЛА РАДИАЦИОННО ОПАСНОГО ПРОИЗВОДСТВА

40 Г.В.Жунтова, Е.С. Григорьева, Т.В. Азизова РИСК ЗАБОЛЕВАЕМОСТИ РАКОМ ЖЕЛУДКА У РАБОТНИКОВ РАДИАЦИОННО ОПАСНОГО ПРЕДПРИЯТИЯ

50 Т.А. Новикова, Ю.А. Алешина, А.Н. Данилов, В.Ф. Спирин СОВРЕМЕННОЕ СОСТОЯНИЕ УСЛОВИЙ ТРУДА И ОЦЕНКА ПРОФЕССИОНАЛЬНОГО РИСКА ЗДОРОВЬЮ РАБОТНИКОВ МУКОМОЛЬНОГО ПРОИЗВОДСТВА

58 Е.В. Федоренко, Н.Д. Коломиец, Т.В. Мохорт, А.Н. Волченко, Е.Г. Мохорт, С.В. Петренко, С.И. Сычик ИНФОРМИРОВАНИЕ О РИСКЕ КАК ЭЛЕМЕНТ УСТОЙЧИВОСТИ СТРАТЕГИИ ЛИКВИДАЦИИ ЙОДДЕФИЦИТНЫХ ЗАБОЛЕВАНИЙ В БЕЛАРУСИ

\section{АНАЛИЗ РИСКА ЗДОРОВЬЮ В ЭПИЛЕМИОЛОГИИ}

68 В.А. Мищенко, О.В. Ладыгин, И.П. Быков, Ю.А. Захарова, А.Г. Сергеев, И.А. Кинясев ЗАБОЛЕВАЕМОСТЬ КЛЕЩЕВЫМ ВИРУСНЫМ ЭНЦЕФАЛИТОМ В РЯДЕ СУБЪЕКТОВ УРАЛЬСКОГО ФЕДЕРАЛЬНОГО ОКРУГА С ПРОГНОЗНОЙ ОЦЕНКОЙ ЭПИДЕМИЧЕСКОЙ СИТУАЦИИ НА КРАТКОСРОЧНЫЙ ПЕРИОД

78 Е.В. Куклев, А.А. Ковалевская, Б.Л. Агапов, С.А. Щербакова ОЦЕНКА ПОТЕНЦИАЛЬНОЙ ЭПИДЕМИЧЕСКОЙ ОПАСНОСТИ СОЧЕТАННЫХ ПРИРОДНЫХ ОЧАГОВ БАКТЕРИАЛЬНЫХ, ВИРУСНЫХ И РИККЕТСИОЗНЫХ ИНФЕКЦИЙ

84 Н.В. Шестопалов, А.Ю. Скопин Л.С. Федорова, Т.В. Гололобова СОВЕРШЕНСТВОВАНИЕ МЕТОДИЧЕСКИХ ПОДХОДОВ К УПРАВЛЕНИЮ РИСКОМ РАСПРОСТРАНЕНИЯ ИНФЕКЦИЙ С АЭРОЗОЛЬНЫМ МЕХАНИЗМОМ ПЕРЕДАЧИ ВОЗБУДИТЕЛЯ 
MEDICAL AND BIOLOGICAL ASPECTS RELATED TO ASSESSMENT OF IMPACTS EXERTED BY RISK FACTORS

L.P. Minaeva, A.I. Aleshkina, Y.M. Markova, A.S. Polyanina, T.V. Pichugina, I.B. Bykova, V.V. Stetsenko, N.R. Efimochkina, S.A. Sheveleva STUDYING THE CONTAMINATION OF TEA AND HERBAL INFUSIONS WITH MOLD FUNGI AS POTENTIAL MYKOTOXIN PRODUCERS: THE FIRST STEP TO RISK ASSESSMENT (MESSAGE 1)

TOXICOLOGICAL RESEARCH IN HEALTH RISK ASSESSMENT

A.V. Voronkov, N.B. Shabanova PRO/ANTIOXIDANT ACTIVITY OF A NEW PIR-10 SUBSTANCE (PYRIMIDINE DERIVATIVE) UNDER EXPERIMENTALLY SIMULATED FOCAL CEREBRAL ISCEMIA IN RATS

\section{HEALTH RISK ANALYSIS IN SOCIOLOGY}

T.N. Inglik, N.M. Chernyavskaya, L.B. Aybazova EPIDEMIOLOGIC ASPECTS RELATED TO TOBACCO SMOKING AS RISK FACTORS FOR FEMALE WORKERS EMPLOYED IN RETAIL TRADE

HEALTH RISK ANALYSIS RELATED TO ORGANIZATIONAL TASKS IN PUBLIC HEALTHCARE

HEMODYNAMICS PARAMETERS AS RISK MARKERS OF POTENTIAL DISEASES IN THE CARDIOUVASCULAR SYSTEM AND THEIR ASSESSMENT IN YOUNG MEN WITH DIFFERENT TYPES OF BLOOD CIRCULATION SELF-REGULATION

M.V. Avdeeva, Yu.A. Kreneva, V.P. Panov, V.N. Filatov, A.V. Mel'tser, L.A. Karasaeva RISK FACTORS THAT CAUSE DEVELOPMENT AND PROGRESSION OF DEGENERATIVE AND DYSTROPHIC DISEASES IN THE SPINAL COLUMN AS PER RESULTS OBTAINED DURING SCREENING TESTS ON PEOPLE LIVING IN SAINT PETERSBURG

\section{I.A. Novikova, L.A. Nekrutenko, T.M. Lebedeva, O.V. Kchlynova, E.A. Shishkina PATIENT AFTER CARDIAC INFARCTION: RISK FACTORS THAT CAN CAUSE NEW CARDIOVASCULAR DISASTERS}

\section{ANALYTICAL REVIEWS}

M.V. Lakhtin, V.M. Lakhtin, V.A. Aleshkin, S.S. Afanasiev NK-CELLS THAT IDENTIFY GLYCOPATTERNS AND THEIR ANTI-TUMOR POTENTIAL AGAINST A BACKGROUND OF EPIDEMICALLY SIGNIFICANT VIRAL INFECTIONS

T.S. Ulanova, T.D. Karnazhitskaya, A.S. Zorina TECHNIQUES FOR DETERMINING PHTHALATES IN FOOD PRODUCTS AIMEd FOR INFANTS' NUTRITION: AN OVERVIEW

NEW LEGAL, REGULATORY AND METHODOLOGICAL DOCUMENTS ISSUED IN THE RF IN THE SPHERE OF HEALTH RISK ANALYSIS
МЕДИКО-БИОЛОГИЧЕСКИЕ АСПЕКТЫ ОЦЕНКИ ВОЗДЕЙСТВИЯ ФАКТОРОВ РИСКА

93 Л.П. Минаева, А.И. Алёшкина, Ю.М. Маркова,

А.С. Полянина, Т.В. Пичугина, И.Б. Быкова, В.В. Стеиенко, Н.Р. Ефимочкина, С.А. Шевелева

ИЗУЧЕНИЕ ЗАГРЯЗНЕННОСТИ ЧАЯ И ЧАЙНЫХ ТРАВЯНЫХ НАПИТКОВ ПЛЕСНЕВЫМИ ГРИБАМИ ПОТЕНЦИАЛЬНЫМИ ПРОДУЦЕНТАМИ МИКОТОКСИНОВ - ПЕРВЫЙ ШАГ К ОЦЕНКЕ РИСКА (СООБЩЕНИЕ 1)

\section{ТОКСИКОЛОГИЧЕСКИЕ ИССЛЕДОВАНИЯ} В ОЦЕНКЕ РИСКА ЗДОРОВЬЮ

103 А.В. Воронков, Н.Б. Шабанова ПРО/АНТИОКСИДАНТНАЯ АКТИВНОСТЬ НОВОЙ СУБСТАНЦИИ РIR-10 (ПРОИЗВОДНОЕ ПИРИМИДИНА) В УСЛОВИЯХ ЭКСПЕРИМЕНТАЛЬНО СМОДЕЛИРОВАННОЙ ФОКАЛЬНОЙ ИШЕМИИ ГОЛОВНОГО МОЗГА КРЫС

\section{АНАЛИЗ РИСКА ЗДОРОВЬЮ В СОЦИОЛОГИИ}

109 Т.Н. Инглик, Н.М. Чернявская, Л.Б. Айбазова ЭПИДЕМИОЛОГИЧЕСКИЕ АСПЕКТЫ ТАБАКОКУРЕНИЯ КАК ФАКТОРА РИСКА СРЕДИ РАБОТНИЦ ТОРГОВОЙ СФЕРЫ

АНАЛИЗ РИСКА ЗДОРОВЬЮ В ЗАДАЧАХ ОРГАНИЗАЦИИ ЗДРАВООХРАНЕНИЯ

118 Л.И. Гречкина ОЦЕНКА ПОКАЗАТЕЛЕЙ ГЕМОДИНАМИКИ КАК МАРКЕРОВ ПОТЕНЦИАЛЬНОГО РИСКА ЗАБОЛЕВАНИЙ СЕРДЕЧНО-СОСУДИСТОЙ СИСТЕМЫ У ЮНОШЕЙ С РАЗНЫМ ТИПОМ САМОРЕГУЛЯЦИИ КРОВООБРАЩЕНИЯ

125 М.В. Авдеева, Ю.А. Кренева, В.П. Панов, В.Н. Филатов, А.В. Мельиер, Л.А. Карасаева ФАКТОРЫ РИСКА РАЗВИТИЯ И ПРОГРЕССИРОВАНИЯ ДЕГЕНЕРАТИВНО-ДИСТРОФИЧЕСКИХ ЗАБОЛЕВАНИЙ ПОЗВОНОЧНИКА ПО РЕЗУЛЬТАТАМ СКРИНИНГОВОГО ОБСЛЕДОВАНИЯ ЖИТЕЛЕЙ САНКТ-ПЕТЕРБУРГА

135 И.А. Новикова, Л.А. Некрутенко, Т.М. Лебедева, О.В. Хльнова, Е.А. Шишкина ПАЦИЕНТ ПОСЛЕ ИНФАРКТА МИОКАРДА: ФАКТОРЫ РИСКА НОВЫХ СЕРДЕЧНО-СОСУДИСТЫХ КАТАСТРОФ

\section{АНАЛИТИЧЕСКИЕ ОБЗОРЫ}

144 М.В. Лахтин, В.М. Лахтин, В.А. Алёикин, С.С. Афанасьев РАСПОЗНАЮЩИЕ ГЛИКОПАТТЕРНЫ NК-КЛЕТКИ ПРОТИВ ОПУХОЛЕЙ НА ФОНЕ ЭПИДЕМИЧЕСКИ ЗНАЧИМЫХ ВИРУСНЫХ ИНФЕКЦИЙ

154 Т.С. Уланова, Т.Д. Карнажииякая, А.С. Зорина ОБЗОР МЕТОДОВ ОПРЕДЕЛЕНИЯ ФТАЛАТОВ В ПИЩЕВЫХ ПРОДУКТАХ ДЛЯ ПИТАНИЯ ДЕТЕЙ РАННЕГО ВОЗРАСТА

164 НОВЫЕ ЗАКОНОДАТЕЛЬНЫЕ, НОРМАТИВНЫЕ И МЕТОДИЧЕСКИЕ ДОКУМЕНТЫ РОССИЙСКОЙ ФЕДЕРАЦИИ В СФЕРЕ АНАЛИЗА РИСКА ЗДОРОВЬЮ 
PREVENTIVE HEALTHCARE:

TOPICAL ISSUES OF HEALTH RISK ANALYSIS

UDC 614.447-02745-004.413

DOI: $10.21668 /$ health.risk/2019.1.01.eng

Read

online

\title{
ON METHODICAL SUPPORT FOR RISK-ORIENTED SURVEILLANCE OVER CONSUMER PRODUCTS SAFETY ON THE UNIFIED ECONOMIC TERRITORY OF THE EURASIAN ECONOMIC UNION
}

\author{
I.V. Gaevskiy ${ }^{1}$, N.V. Zaitseva ${ }^{2}$, I.V. May ${ }^{2}$, S.T. Karymbaeva ${ }^{1}$, \\ S.I. Sychik ${ }^{3}$, E.V. Fedorenko ${ }^{3}$
}

${ }^{1}$ Eurasian Economic Commission, Department for Sanitary and Phytosanitary measures, build. 2, 2 Letnikovskaya Str., Moscow, 115114, Russian Federation

${ }^{2}$ Federal Scientific Center for Medical and Preventive Health Risk Management Technologies, 82 Monastyrskaya Str., Perm, 614000, Russian Federation

${ }^{3}$ Scientific-Practical Hygiene Center, 8 Akademicheskaya Str., Minsk, 220012, Belarus

Risk-oriented surveillance is a tool for state regulation over consumer products safety; it is fixed in the legislation of all the states belonging to the Eurasian Economic Union (EAEU). This approach involves concentrations of efforts by all controlling authorities on objects that cause high health risks for population with simultaneous easing off administrative barriers for those objects that cause insignificant risks. It is necessary to work out uniform and easy-to-replicate methodical approaches to organizing risk-oriented surveillance over products in the EAEU and it makes our research truly vital. It would allow to preserve independent national surveillance systems and simultaneously obtain comparable results that would be recognized in all the member states thus ensuring high confidence in any obtained data.

Our research goal was to work out an algorithm and a system of procedures for risk-oriented surveillance over safety of consumer products distributed on the unified EAEU market.

We analyzed regulatory, legal, and methodical documents on issues related to assessing population health risks occurring when consumer products are distributed; forms of statistical reports and algorithms applied for planning control and surveillance activities in the EAEU member states, other countries and unions. We took data collected in Russia and Belarus to analyze results obtained during control and surveillance activities performed in the sphere including results of more than 3 million various laboratory examinations of consumer products conducted over 2014-2017.

We suggest an algorithm for risk-oriented surveillance over consumer products safety that includes three basic stages: 1) ranking of activities performed by juridical persons or private entrepreneurs in the sphere of consumer products distribution as per potential population health risks. The basic goal at this stage is to spot out objects that are subject to the most frequent and profound inspections performed by authorized governmental authorities entitled to check consumer products safety and protect population health; 2) products classification as per population health risks for drawing up surveillance activities schedules. The basic goal at this stage is to make up a list of the most "risky" groups of products for a documentary and laboratory inspection performed at a specific economic entity; 3) determining priority parameters for laboratory support of surveillance activities based on "risk profiles" creation. The goal at this stage is to optimize laboratory support provided for surveillance and to make it more "targeted" via substantiating those parameters of products that are related to the most frequently registered violation of standards and the greatest population health risks.

Procedures and software are developed for each stage in the suggested algorithm.

Key words: consumer products, risk-oriented surveillance, methodical support.

(C) Gaevskiy I.V., Zaitseva N.V., May I.V., Karymbaeva S.T., Sychik S.I., Fedorenko E.V., 2019

Igor' V. Gaevskiy - Candidate of Medical Sciences, Director of the Department for Sanitary, Phytosanitary, and Veterinary Measures (tel.: +7 (495) 669-24-00).

Nina V. Zaitseva - Academician, Member of the Russian Academy of Sciences, Doctor of Medical Sciences, Professor, Research Supervisor (e-mail: znv@fcrisk.ru; tel.: +7 (342) 233-11-25; ORCID: https://orcid.org/0000-0003-2356-1145).

Irina V. May - Doctor of Biological Sciences, Professor, Deputy Director responsible for research work (e-mail: may@fcrisk.ru; tel.: +7 (342) 237-25-47; ORCID: https://orcid.org/0000-0003-0976-7016).

Saliya T. Karymbaeva - Deputy Director of the Department for Sanitary, Phytosanitary, and Veterinary Measures (e-mail karymbaeva@eecommission.org; tel.: +7 (495) 669-24-00).

Sergey I. Sychik - Candidate of Medical Sciences, Associate Professor, Head of the Scientific-Practical Hygiene Center (e-mail: respch@rspch.by; tel. +375 172-84-13-70; ORCID: http://orcid.org/0000-0002-5493-9799).

Ekaterina V. Fedorenko - Candidate of Medical Sciences, Associate Professor, Deputy Director responsible for support of practical sanitary-epidemiologic surveillance and work with the Eurasian Economic Commission (e-mail: afedorenko71@mail.ru; tel. +375-172-84-13-70; ORCID: http://orcid.org/0000-0003-1240-1234). 
The Treaty on the Eurasian Economic Union signed on May 292014 declares in its Clause No. 56 that the member states are to pursue a coordinated policy in the sphere of sanitary measures application in order to provide sanitary-epidemiologic welfare of the population. Sanitary measures are to be applied basing on the principles that are scientifically substantiated and to an extent necessary for saving lives and improving people's health. Products safety management is a most essential component in implementation of this coordinated policy. At the moment attention is being focused on safety of consumer products distributed on the unified EAEU market as achieving this safety is more than vital. It is related to intense technological development (including nanotechnologies), and these new technologies are often not studied enough in terms of their hygienic parameters $[1,2]$; creation of new chemicals [3-5] and biological agents [5, 6] which are directly included into products or contact them; persisting threats of secondary and tertiary products contamination [7-9] etc.

The member states provide criterion grounds for products safety that are based on a comprehensive and wide set of sanitary-epidemiologic requirements and standards fixed in unified sanitary and technical regulations. This system of standards and regulations is being constantly developed basing on new scientific data and research [10]. Simultaneously new activities are being worked out that are aimed at lowering state interference into business and reducing administrative barriers for production and trade. A balance between consumer safety and state regulation over business can be reached, among over things, via wide implementation of riskoriented surveillance. The main purpose of such surveillance is to concentrate efforts made by state surveillance authorities on products that cause high risks for consumers' health and to minimize surveillance over products causing law risks [11-13].

Risk-oriented state control (surveillance) is fixed in legal documents issued in many countries and by many international organizations and is efficiently applied in different management spheres. For example, the EU Regulation $2017 / 625^{1}$ fixes that competent surveillance authorities should focus on objects causing high risks taking into account inspection reports and applying qualitative informative and methodical base when they perform control and surveillance activities. These bases are prepared by such organizations as European Food Safety Authority or EFSA, Food and Veterinary Office or FVO, and others. For example, EFSA provides a methodological base for assessing products risks by systematic publishing of relevant Guidances for Risk Assessment which can be used by all parties who are interested in assessing products safety, such as manufacturers, distributors, authorities responsible for assessing conformity, and control and surveillance authorities [14-16]. It is fixed in legislation that all concerned partied are to be obligatory informed about hazardous products ${ }^{2}$. Risk-oriented surveillance is also fixed in the legislation in the USA, Canada, etc. [17-20].

The EAEU member states also adhere to risk-oriented surveillance [21, 22]. Thus, Clause No. 8.1 of the RF Federal Law No.294-FZ ${ }^{3}$ fixes a risk-oriented approach to state control in order to achieve optimal use of labor, material, and financial resources required for accomplishing state control (surveillance), to lower expenses borne by juridical persons and private entrepreneurs, and to make activities performed by state

\footnotetext{
${ }^{1}$ Regulation (EU) 2017/625 of the European Parliament and of the Council of 15 March 2017 on Official Controls and Other Official Activities Performed to Ensure the Application of Food and Feed Law, Rules on Animal Health and Welfare, Plant Health and Plant Protection Products. - URL: http://eur-lex.europa.eu/legalcontent/EN/TXT/PDF/?uri=CELEX:32017R0625\&from=EN (date of visit February 07, 2019).

${ }^{2}$ Commission Regulation (EU) No 16/2011 of 10 January 2011: Laying down implementing measures for the Rapid alert system for food and feed [web-source] // Official Journal ofthe European Communities. 2011. - URL: http://eur-lex.europa.eu/legal-content/EN/TXT/PDF/?uri=0J:L:2011:006:FULL\&from=EN (date of visit February 06, 2019).

${ }^{3}$ The Federal Law "On protecting rights of juridical persons and private entrepreneurs when accomplishing state control (surveillance) and municipal control" issued on December 26, 2008 No. 294-FZ (the last edition). URL: http://www.consultant.ru/document/cons_doc_LAW_83079/ (date of visit February 01, 2019).
} 
control (surveillance) authorities more efficient. In Belarus, "The Regulations on the order of inspections organization and procedure" approved by the Order signed by the Belarus President on October 16, 2009 No. 510 approve the criteria for assigning economic entities that are subject to surveillance into a specific risk group for drawing up inspections schedules.

The Code issued in Kazakhstan on October 29, 2015 No. 375-V and entitled "The Business Code of the Kazakhstan Republic" ${ }^{5}$ (Chapter 13, Clause 141) specifies that state control and surveillance are performed taking into account distribution of economic entities that are subject to surveillance into four groups basing on risk assessment. Risk is considered as a possible damage done to people's lives or health, the environment, legal interests of physical and juridical persons, or valuable interests of a state due to activities performed by an economic entity under surveillance; a degree of a such damage should also be taken into account.

Risk-based systems for drawing up inspections schedules are fixed in the Law issued in Armenia "On organization and accomplishment of inspections in the Republic of Armenia" ${ }^{6}$ and also in the Law issued in Kirgizstan on May 25 2007 No. 72 "On a procedure for accomplishing inspections at economic entities"7.

But at the same time it is vital to develop uniform and easy-to-replicate methodical approaches to organizing risk-oriented surveillance over products. If experts had an access to a united criterion base for determining products safety and common approaches to differentiation (classification or ranking) of surveillance objects as per risk levels, it would allow to preserve independent systems for national state surveillance and simultaneously obtain comparable results recognized in all the member states thus ensuring high confidence in all the obtained data.

All the above mentioned gave grounds for attempts made by the Eurasian Economic Commission (EAEC) to develop common principles for creating and functioning of a typical riskoriented model for control and surveillance activities as regards providing products safety on the territory of the Eurasian Economic Union. In 2017-2018 Russian and Belorussian experts who worked together within a project supported by the EAEC ${ }^{8}$, substantiated certain approaches that could be applied within national systems for control over products safety as a unified methodical base. The present paper dwells on these approaches.

Our research goal was to work out an algorithm and a system of procedures for riskoriented model of surveillance over safety of consumer products distributed on the common EAEU market.

Research objects and methods. The algorithm and the system of procedures were developed taking into account regulatory, legal, and methodical documents existing in the sphere of population health risks assessment, providing products (goods) safety, and accomplishing control (surveillance) over products distributed on the market (there are approximately 200 regulatory and methodical documents issued in the EAEU member states - Belarus, Kazakhstan, Kirgizstan, Armenia, and the Russian Federation); we also examined and took into account documents issued by international organizations (including the World Trade Organization, Codex Alimentarius Commission, the World Health Organization, the UN Food and Agriculture Organization, The Organization for Economic Cooperation and Development, The

${ }^{4}$ The Order signed by the Belarus President on October 16, 2009 No. 510 " On development of control (surveillance) activities in Belarus. URL: www.bgs.by/files/files/10.doc (date of visit February 01, 2019).

${ }^{5}$ The Code of Kazakhstan Republic "The Business Code of the Kazakhstan Republic" (with amendments and latest supplements on January 21, 2019) URL: https://online.zakon.kz/Document/?doc_id=38259854 (date of visit February 01, 2019).

${ }^{6}$ The Law of the Republic Armenia issued on July 12, 2000 No. ZR-60 "On organization and accomplishment of inspections in the Republic of Armenia". URL: http://base.spinform.ru/show doc.fwx?rgn=3039 (date of visit February 01, 2019).

${ }^{7}$ The Law of the Kirgizstan Republic issued on May 25, 2007 No. 72 "On a procedure for accomplishing inspections at economic entities". URL: http://cbd.minjust.gov.kg/act/view/ru-ru/202105 (date of visit February 01, 2019).

${ }^{8}$ The scientific research entitled "Risk-oriented surveillance model in the sphere of providing safety of products for people's health".Cipher N-17/197. 
International Organization for Standardization, The European Committee for Standardization, etc.). We examined statistical reports, algorithms for planning control and surveillance activities including those ones accomplished under compliance with requirements fixed in the WTO agreements on sanitary and phytosanitary measures, standards developed by the Codex Alimentarius Commission etc.; it allowed us to choose data sources that were the most suitable for creating a risk-oriented surveillance model in the EAEU member states. When modeling causeand-effect relations between frequency of cases in which obligatory requirements to products safety were violated and detected damages done to consumers' health, we applied data taken from the state statistics collected in Russia and Belarus including analysis of cases in which damage was done to consumers' health. Certain conclusions and suggestions were based on results of more than 3 million laboratory research on products collected over 3 years (2015-2017).

When setting a task to create a risk-oriented model for surveillance over products, we assumed that a) products themselves were not a subject in legal relationships; b) goods can appear on the consumer market only due to activities performed by juridical persons or private entrepreneurs 9 ; c) products (goods) safety can be managed only via managing activities performed by juridical persons or private entrepreneurs. sitions:

We took into account the following propo-

- scheduled surveillance over products is accomplished through control and surveillance over juridical persons and private entrepreneurs. Consequently, the most immediate task here is to identify juridical persons and private entrepreneurs that cause high risks for consumers' health;

- when a control and surveillance inspection is being accomplished directly at an economic entity, it is impossible to examine all the goods or products. Therefore, it is very important to have a priori knowledge what products (goods) can be the most hazardous or "risky";
- compliance of goods to safety criteria is, as a rule, determined with instrumental research and volumes of such research are often limited. Therefore, it is vital to primarily control those parameters of products non-compliance of which to hygienic standards can most certainly result in the highest consumer health risks.

Basic results. We suggest an overall algorithm for a risk-oriented model for surveillance over products safety which includes three main stages:

1) ranking (classifying) activities performed by juridical persons or private entrepreneurs and related to consumer products distribution as per potential risks of damage to population health. The main goal at the stage is to spot out economic entities which should be subject to the most frequent and profound inspections accomplished by state bodies authorized to monitor products safety and to protect consumers' health;

2) classifying products as per possible risks of damage to health in order to draw up inspections schedules. The main goal at this stage is to make up a list of the most "risky" product groups in order to perform a documentary and laboratory inspection at a specific economic entity (juridical person or private entrepreneur);

3) determining priority parameters for laboratory support provided for surveillance activities on the basis of created "risk profiles". The main goal at the stage is to optimize laboratory support provided for surveillance, and to make it more "targeted" via substantiating those product parameters which are most frequently non-compliant with requirements fixed in standards and violation of which causes the highest consumer health risks.

Implementation of the suggested model is aimed at determining exactly unsafe products that cause the highest consumer health risks during surveillance activities and to do it in the most convincing way applying all the available tools.

The algorithm is given in greater detail on Figure 1.

\footnotetext{
${ }^{9}$ Products made by citizens for their private purposes and for consumption at their households were not considered in the research.
} 


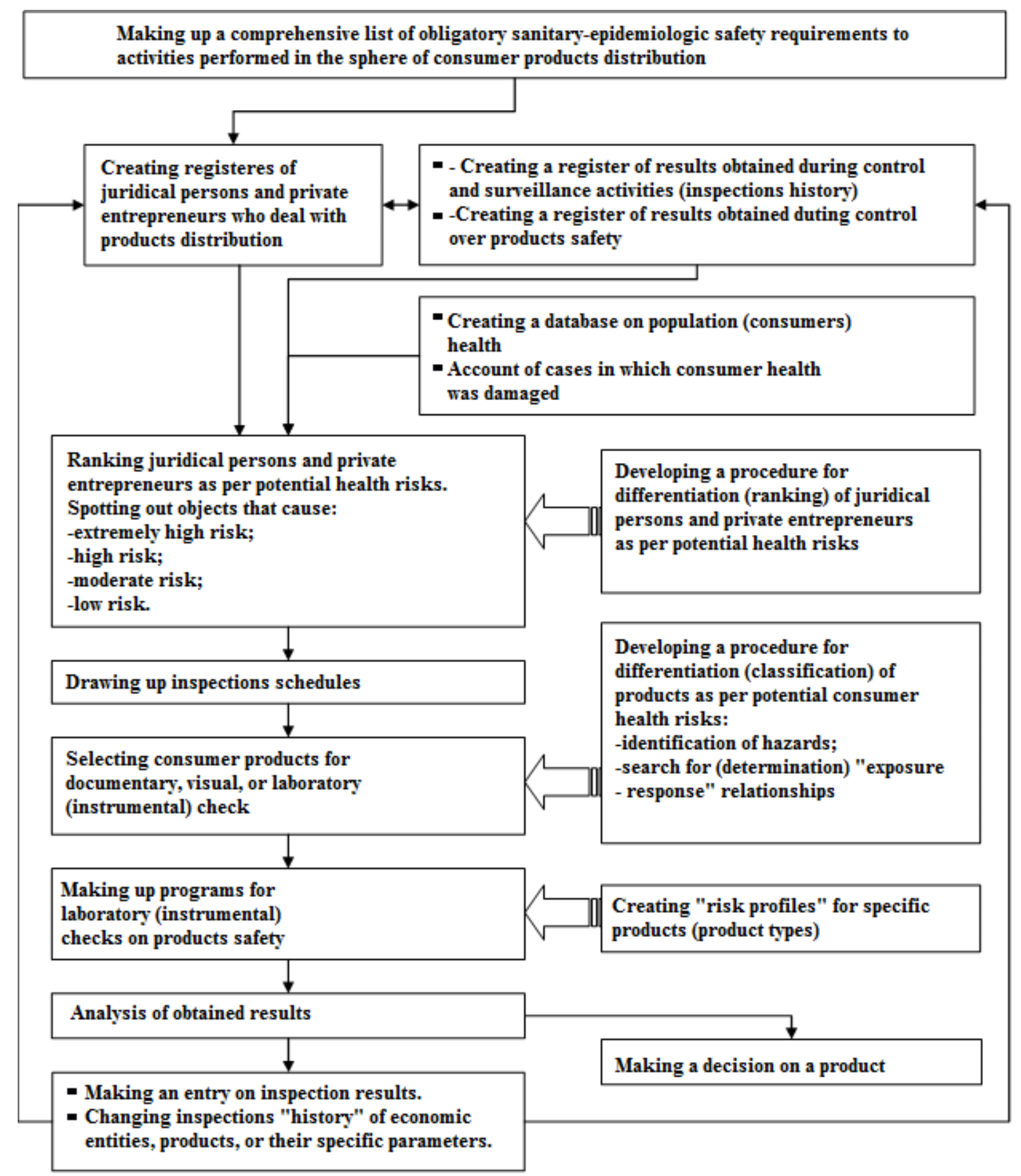

Figure 1. An overall algorithm for organizing control and surveillance activities taking into account classification of products as per potential health risks

The first stage is ranking (classifying) activities performed by juridical persons or private entrepreneurs in the sphere of consumer products distribution as per potential population health risks; it involves having the complete data on economic entities under surveillance which are systemized in registers, inventories, databases, etc. Such registers or databases should contain data on activities performed by a ju- ridical person or a private entrepreneur, where they take place and how long a production process is, as well as volumes of manufactured (distributed) goods or rendered services. Besides, it is extremely important to accumulate and systematize results of control and surveillance activities including results of documentary, visual, and laboratory examinations of products as well as registers of cases in which 
damage was done to population health (or if such registers have not been created yet, there can be registers of population health parameters). The registers are considered to be an information database for calculating and predicting probable frequency of obligatory requirements violation by economic entities performing various activities in the sphere of consumer products distribution and probable negative responses to such violations (in case when obligatory sanitary requirements are violated, it can be probability of deaths or diseases among potential consumers, breach of sanitary-epidemiologic welfare etc.)

A scope of potential negative impacts (that is, health damage cases) is determined by scales of activities performed by a juridical person or a private entrepreneur. We suggest to assess a gravity of damage that was done according to the WHO recommendations applying a scale from 0 to 1 , where 1 means death; any figures close to 1 are considered grave health disorders, and those close to 0 are mild disorders, symptoms, syndromes, etc. [23].

Methodical approaches to classification can vary significantly; however, just like any other risk assessment techniques, they should take into account both probability of a hazardous event (violation of standard levels fixed for hazardous factors) and a gravity of consequences caused by this event. In order to exclude or minimize subjective experts estimations, we suggest to develop a risk assessment procedure on the basis of actual statistical data collected during control and surveillance activities, data on hazards related to activities performed by juridical persons or private entrepreneurs and products distributed on the market, statistics on health damage cases or any other data on health disorders, and mathematic modeling techniques.

In full conformity with international approaches, we suggest to assess a risk as a combination of probability, gravity, and a scope of negative exposure as per the following formula (1):

$$
R^{I}=\sum_{i}\left(p_{i} u_{i}\right) M
$$

where $p_{i}$ is a probability that $\mathrm{i}$-th requirement (standard) in sanitary legislation is violated at industrial objects where I-type activity is performed;

$u_{i}$ is a parameter that characterizes damage done to population health when $i$-th requirement (standard) in sanitary legislation is violated at industrial objects where a specific activity is performed; it is calculated as

$$
u_{k}=\sum_{i} \alpha_{i k} g_{i}
$$

where $\alpha_{i}$ is a parameter that reflects changes in mortality or morbidity frequency when frequency of violation as per $k$ - th clause in the legislation increases by 1 ; gi is a parameter that reflects gravity of $i$-th health disorder varying within a range from 0 to 1 .

$M$ is a parameter that characterizes number of population exposed to activities performed by an industrial enterprise.

Probability of a case in which requirements are violated is determined basing on inspections histories of juridical persons and private entrepreneurs and, taking into account "precaution" principles, can be taken as a $95 \%$ percentile of violations frequency over several years. It means that a risk as per "violation probability" criterion can be underestimated for not more than $5 \%$ of object under surveillance. (For example, we analyzed results of control and surveillance activities performed by Rospotrebnadzor in 2014-2017 at more than 1,000 retail outlets and revealed that noncompliance with sanitary-epidemiologic requirements to food products and materials and products that contacted them was registered with an average frequency equal to 0.58 per 1 inspection. Maximum frequency amounted to $1.37 ; 95 \%$-percentile was equal to 0.85 per 1 inspection). Violations frequency and 95\%percentile which is taken into account when economic entities or products are classified should be revised at least once a year.

Probability and gravity of a response (damage done to a consumer health) is the second component in a risk caused by an economic entity and its activities. An obligatory action at this stage is to identify a hazard, to describe hazardous factors and negative consequences caused by exposure to such factors as comprehensively as it's only possible. Relative damage 
to health caused by violation of obligatory safety requirements $\left(u_{k}^{l}\right)$ is calculated on the basis of systemic, including expert one, analysis of cause-and-effect relations between frequency of legislation violations and prevalence of health disorders (mortality and primary morbidity) among population taking into account their gravity. This task is complicated and scienceintense, and it requires access to databases on violations frequencies and population health.
Obtained mathematical models which are biologically substantiated are subject to obligatory statistical significance check. Only authentic correlation models can be applied to assess risks. Table 1 contains several models obtained in the research and applied to assess health risks caused by products. The models can be applied many times, they can be supplemented and revised by scientific organizations from time to time.

Table 1

An example of models that describe cause-and-effect relations between frequency of cases in which obligatory requirements to activities related to consumer food products distribution are violated and population health disorders ( $\mathrm{a}$ is a number of cases per 1 violation)

with assessing potential damage caused by these violations (a copy taken from a system of models obtained basing on the analysis of data collected in 84 RF regions over 2014-2017)

\begin{tabular}{|c|c|c|c|c|c|c|c|}
\hline \multirow[b]{2}{*}{ Category } & \multirow{2}{*}{$\begin{array}{c}\text { A clause } \\
\text { in 52-FL } \\
\text { which was } \\
\text { violated }\end{array}$} & \multirow[b]{2}{*}{ Nosology } & \multirow[b]{2}{*}{ Contingent } & \multicolumn{2}{|c|}{$\begin{array}{c}\text { Model } \\
\text { parameters }\end{array}$} & \multirow{2}{*}{$\begin{array}{c}\text { Gravity } \\
\text { of } \\
\text { a disorder } \\
(\mathrm{g})\end{array}$} & \multirow{2}{*}{$\begin{array}{c}\text { A parameter } \\
\text { that character- } \\
\text { izes damage to } \\
\text { health caused } \\
\text { by violation of } \\
\text { legal require- } \\
\text { ments }(\mathrm{u})\end{array}$} \\
\hline & & & & $a$ & $F$ & & \\
\hline \multirow{5}{*}{$\begin{array}{l}\text { Food products } \\
\text { manufactur- } \\
\text { ing, catering } \\
\text { and retail } \\
\text { trade in food } \\
\text { products, } \\
\text { overall }\end{array}$} & Clause 15 & Gastritis and duodenitis & Adults & 0.00150 & 22.08 & 0.140 & 0.00021 \\
\hline & Clause 15 & Gastritis and duodenitis & $\begin{array}{c}\text { Total } \\
\text { population }\end{array}$ & 0.00160 & 23.33 & 0.112 & 0.00018 \\
\hline & Clause 17 & Digestive organs diseases & Adults & 0.00930 & 8.12 & 0.161 & 0.00150 \\
\hline & Clause 19 & Pancreas diseases & Children & 0.00910 & 7.65 & 0.441 & 0.00400 \\
\hline & Clause 20 & $\begin{array}{l}\text { Diseases of the blood } \\
\text { and blood-forming or- } \\
\text { gans and certain disor- } \\
\text { ders involving the im- } \\
\text { mune mechanism }\end{array}$ & Adults & 0.03310 & 20.31 & 0.273 & 0.00902 \\
\hline \multirow{3}{*}{$\begin{array}{l}\text { Food products } \\
\text { manufactur- } \\
\text { ing, including } \\
\text { drinks; to- } \\
\text { bacco prod- } \\
\text { ucts manufac- } \\
\text { turing }\end{array}$} & Clause 17 & Enteric infections & Adults & 0.01950 & 18.44 & 0.016 & 0.00031 \\
\hline & \multirow{2}{*}{ Clause 19} & \multirow{2}{*}{$\begin{array}{c}\text { Stomach } \\
\text { and duodenum ulcer }\end{array}$} & Children & 0.00060 & 6.21 & 0.181 & 0.00012 \\
\hline & & & $\begin{array}{c}\text { Total popu- } \\
\text { lation } \\
\end{array}$ & 0.00011 & 6.85 & 0.196 & 0.00002 \\
\hline \multirow[t]{3}{*}{ Catering } & Clause 19 & $\begin{array}{c}\text { Non-infectious } \\
\text { enteritis and colitis }\end{array}$ & Children & 0.01690 & 13.13 & 0.372 & 0.00630 \\
\hline & \multirow[b]{2}{*}{ Clause 25} & Gastritis and duodenitis & Adults & 0.00487 & 15.26 & 0.139 & 0.00068 \\
\hline & & Gastritis and duodenitis & $\begin{array}{c}\text { Total } \\
\text { population }\end{array}$ & 0.00444 & 13.37 & 0.126 & 0.00056 \\
\hline \multirow{4}{*}{$\begin{array}{l}\text { Retail trade in } \\
\text { food products, } \\
\text { including } \\
\text { drinks, and } \\
\text { tobacco prod- } \\
\text { ucts } \\
\end{array}$} & \multirow[b]{2}{*}{ Clause 15} & Gastritis and duodenitis & Adults & 0.00154 & 8.96 & 0.139 & 0.00022 \\
\hline & & Gastritis and duodenitis & $\begin{array}{c}\text { Total } \\
\text { population }\end{array}$ & 0.00165 & 8.15 & 0.126 & 0.00018 \\
\hline & Clause 17 & Digestive organs diseases & Adults & 0.00930 & 14.87 & 0.161 & 0.00150 \\
\hline & Clause 19 & $\begin{array}{c}\text { Certain infectious and } \\
\text { parasitic diseases }\end{array}$ & Adults & 0.03450 & 20.12 & 0.288 & 0.00993 \\
\hline
\end{tabular}


Table 2

A scale for classifying activities performed by juridical persons or private entrepreneurs as per potential health risk

\begin{tabular}{|c|c|c|c|}
\hline Hazard category & Health risk category & Health risk value & $\begin{array}{l}\text { Recommended frequency } \\
\text { of scheduled inspections }\end{array}$ \\
\hline 1 hazard category & Extremely high & More than $1 * 10^{-3}$ & $\begin{array}{c}\text { The highest (in conformity with the EAEU } \\
\text { member- states legislations), } \\
\text { for example, at least once a year }\end{array}$ \\
\hline 2 hazard category & $\mathrm{H}$ & $10^{-4}<\mathrm{R} \leq 1 * 10^{-3}$ & \multirow{4}{*}{$\begin{array}{l}\text { From } 1 \text { time in } 2 \text { years } \\
\text { to } 1 \text { in } 5-7 \text { years }\end{array}$} \\
\hline 3 hazard category & Considerable & $10^{-5}<\mathrm{R} \leq 1 * 10^{-4}$ & \\
\hline 4 hazard category & Average & $10^{-6}<\mathrm{R} \leq 1 * 10^{-5}$ & \\
\hline 5 hazard category & Moderate & $10^{-7}<\mathrm{R} \leq 1 * 10^{-6}$ & \\
\hline 6 hazard category & Low & $\mathrm{R}<10^{-7}$ & Are released from scheduled inspections \\
\hline
\end{tabular}

Number of population exposed to activities performed by an industrial object is determined as a function of production capacity at an economic entity under surveillance or rendered services.

When all the components are known (frequency of registered violations, a scope of health damage as per 1 violation, number of exposed population), activities performed by an economic entity under surveillance can be characterized with a certain risk value.

We suggest a risk scale that can be applied to classify surveillance objects; it allows to assign activities performed by a certain object to this or that risk category taking into account scopes of such activities (Table 2).

Objects ranking gives grounds for differentiation of scheduled inspections frequency and their procedures. We suggest to fix maximum frequency of inspections for objects that cause extremely high and high risks and minimal frequency for those that cause low risks (or to completely release them from any scheduled inspections). Scheduled inspections at objects that cause extremely high, high, and, partially, considerable risks should be field ones and there should be laboratory support provided for them.

The approaches were tested on economic entities in Russia that were subject to surveillance. Totally, almost 400 thousand juridical persons and private entrepreneurs that dealt with catering were under state surveillance; the tests revealed that about $2.5 \%$ of them could be ranked as objects causing extremely high risk, and $5.5 \%$, high risk. And it is these economic entities that are subject to the most frequent and systemic control. Approximately $17.3 \%$ economic entities cause significant risks, and $38.55 \%$, average risk. Scheduled inspections at such objects should be performed with lower frequency. And almost 10\% of economic entities are ranked as objects with low risk and they can be released from any scheduled inspections thus allowing to redirect resources of a surveillance authority and to concentrate its efforts on objects that cause high risks. A share of objects that cause extremely high and high risks in the sphere of wholesale and retail trade (predominantly in food products) amounted to 2.1 and $4.87 \%$ respectively; objects that caused low risks accounted for almost $20 \%$. The obtained data are well in line with data taken from scientific literature; according to literature sources, a share of objects that create high risks and are subject to the most frequent control by surveillance authorities doesn't exceed $8-10 \%$ of the overall number of objects under state surveillance. But as for unscheduled inspections performed according to the rules fixed in the legislation of the EAEU member states, they are not excluded and can take place at any time. Besides, a risk-oriented model can (and should) include some measures that can assign an object either into a stricter category (when considerable violations of obligatory requirements are detected during an inspection) or into a less strict one (when there are no violations of obligatory requirements and all the recommendations given by surveillance authorities or any other conditions fixed for the process have been adhered to).

Risk-oriented surveillance over activities performed by juridical persons and private en- 
trepreneurs is supplemented with a similar approach to surveillance over products and it allows control and surveillance authorities to choose the most hazardous products for documentary and laboratory examinations.

Methodical approaches allow to quantitatively estimate risks as a combination of potential frequency with which obligatory requirements to products can be violated and relative damage done to consumers' health in a case when specific requirements are violated. The formula for calculating risks caused by food products is given below (2).

$$
R_{\text {пиш }}^{I}=\sum_{i}\left(p_{i}^{I} u_{i}^{I}\right) W
$$

where $p_{i}^{I}$ is a probability that obligatory safety requirements to food products are violated as per i-th hazard factor during a single inspection. A hazard factor can be a chemical, a microbe or a parasitic agent, a radiological parameter, a genetically modified organism, or any other factor that is examined when control and surveillance activities take place;
$u_{i}^{I} \quad$ is relative damage to health caused by violations of sanitary-epidemiologic requirements to an i-th hazard factor related to food products;

$W$ is a coefficient that characterizes consumption of food products by people.

Frequency (probability) of cases in which obligatory safety requirements to products can be violated as per i-th hazard factor during a single inspection is determined as per statistical data provided by a surveillance authority; it is calculated as a ratio of examination results with detected violations of requirements and standards to the overall number of examinations.

Damage to health is assessed either as per results of cause-and-effect relations modeling or as per data taken from relevant scientific literature. Table 3 contains examples of mathematical models that show "violation of obligatory requirements to food products safety" - " consumers' health disorders" relations (they are taken out of more than 800 authentic models that were obtained during the present research).

Table 3

Examples of parameters included into mathematical models that show

"violations of sanitary standards for products safety - consumers' health disorders" relations

\begin{tabular}{|c|c|c|c|c|c|}
\hline \multirow{2}{*}{$\begin{array}{c}\text { Products } \\
\text { (group } \\
\text { of products) }\end{array}$} & \multirow{2}{*}{$\begin{array}{c}\text { A parameter with } \\
\text { detected violation } \\
\text { of sanitary standards }\end{array}$} & \multirow{2}{*}{$\begin{array}{l}\text { Population } \\
\text { contingent }\end{array}$} & \multirow[t]{2}{*}{ Health disorders } & \multicolumn{2}{|c|}{$\begin{array}{c}\text { Model } \\
\text { parameter }\end{array}$} \\
\hline & & & & $a^{*}$ & $F$ \\
\hline Confectionary & Microbiological parameters & Total population & Enteric infections & 12.99 & 16.22 \\
\hline Canned food & Microbiological parameters & Total population & $\begin{array}{c}\text { Certain infectious and } \\
\text { parasitic diseases }\end{array}$ & 50.00 & 25.12 \\
\hline $\begin{array}{l}\text { Dairy canned } \\
\text { products }\end{array}$ & Microbiological parameters & Children & Enteric infections & 19.81 & 17.17 \\
\hline Cream products & Microbiological parameters & Children & Enteric infections & 10.47 & 12.43 \\
\hline Cream products & Microbiological parameters & $\begin{array}{c}\text { Older than employable } \\
\text { population }\end{array}$ & Enteric infections & 0.28 & 6.88 \\
\hline Cream products & Microbiological parameters & Employable population & Enteric infections & 8.96 & 8.98 \\
\hline $\begin{array}{l}\text { Cooked products } \\
\text { in retail outlets }\end{array}$ & Pathogenic microorganisms & Total population & $\begin{array}{c}\text { Certain infectious and } \\
\text { parasitic diseases }\end{array}$ & 500.50 & 19.63 \\
\hline $\begin{array}{l}\text { Meat and meat } \\
\text { products }\end{array}$ & Antibiotics & Children & $\begin{array}{l}\text { Non-infectious enteritis } \\
\text { and colitis }\end{array}$ & 12.21 & 17.11 \\
\hline $\begin{array}{l}\text { Butter and fat } \\
\text { products }\end{array}$ & Pesticides & $\begin{array}{c}\text { Older than employable } \\
\text { population }\end{array}$ & Diseases of the liver & 87.04 & 12.56 \\
\hline Vegetables & Nitrates & Total population & $\begin{array}{c}\text { Diseases of the blood and } \\
\text { blood-forming organs }\end{array}$ & 56.93 & 18.45 \\
\hline
\end{tabular}

* A growth in morbidity (cases / 100 thousand people) when frequency of violations grows by $1 \%$. 
Risk assessment methodology is quite versatile and it makes all the sequential steps in the algorithm interrelated and consistent. But at the same time, data that are applied in calculations can be completely different in the EAEU member states in spite of the unified methodological base. Violations of obligatory requirements are detected with significantly different frequency in different regions due to peculiarities of products manufacturing, storage, and transportation to an end customer.

Thus, alcohol and non-alcohol drinks, honey, tropical and subtropical fruit and some other goods in Armenia are ranked as "lowrisk products" while in the RF a probability that requirements to safety of these products are violated is rather high. This discrepancy by no means is to be considered an inconsistency. It is quite possible that certain product groups differ significantly in the EAEU member states. But still, priorities that exist in different EAEU countries can be interesting and important for surveillance authorities of a state that imports products manufactured in another state on its customs territory. We should note that, nevertheless, if unified methodical approaches to selecting priorities were applied, it would allow to assess objectivity of estimations made in each EAEU member state.

The third stage in the algorithm for riskoriented surveillance implementation involves creating risk profiles for a specific product in order to optimize laboratory control. A risk profile is a set of standardized safety parameters that is typical for a specific product; the set should include parameters regulated by such hygienic requirements that are violated most frequently and gravity of these violations should also be taken into account.

Creation of a risk profile for a product involves profound analysis of long-term laboratory research on products quality and safety. The basic tasks here are to spot out products groups (types) which are characterized with the highest probability that sanitary-hygienic standards and requirements to them are violated and these violations can be detected with instrumental research; to identify parameters obligatory requirements to which are violated with the highest frequency; to assess potential consumers' health risk when products with detected violations are distributed on the market.

For example, we analyzed how frequently safety requirements were violated and assessed health risks when examining migration of chemical admixtures from construction and finishing materials (approximately 3 thousand samples of products belonging to 30 groups in the Commodity Nomenclature for Foreign Economic Activities (CN FEA) on the RF territory). We detected the following factors that caused risks for consumers' health: formaldehyde, phenol, hydrogen chloride and ammonia; these factors formed risk profiles for products from the CN FEA groups 4410, 4411, 4412 (flakeboards, wood-fiber boards, pressed plywood, etc.); other standardized admixtures (approximately 16 parameters) were practically never registered in quantities higher than standards and didn't cause any health risks.

We revealed that acrylonitrite was a risk factor for materials from the group 4814 (acrylic wallpapers etc.); other migrating standardized admixtures didn't cause any significant risks.

There were several products groups $(\mathrm{CN}$ FEA 3922 - bathtubs and sinks; CN FEA 4601 wicker products and materials for wickerwork, mats, screens, etc; CN FEA 4823 - paper, cardboard, cellulose cotton, etc.; CN FEA 5602 felt; CN FEA 5703-5705 - textile carpets, carpets made of felt or taffeta; CN FEA 5905 - textile wallpapers) for which data collected over long-term period were analyzed and the analysis revealed it was not necessary to provide scheduled systemic laboratory support for them as frequency of detected violations in terms of chemicals migration amounted to less than $0.01 \%$, and hygienic standards in all the detected cases were exceeded only slightly, by 1.1-2.0. Therefore, laboratory support provided for a surveillance activity should be oriented at estimating priority risk factors including an increase in number of examined samples. Other admixtures can be included into inspections programs on the residual principle.

Stricter and more frequent control over risky products and orientation at priority parameters in inspection programs with simultaneous decrease in frequency of measuring parameters 
that are less informative should eventually provide growth in consumer market safety without any increase in overall expenses on instrumental support provided for inspections.

Undoubtedly, it is necessary to perform laboratory control as per a wide range of parameters. Methodical approaches indicate that this control should either be performed in a screening mode when profound examinations are accomplished on a great quantity of similar products and are aimed at creating a risk profile for them, or it should be random and performed on random samplings in order to assess average compliance with hygienic standards fixed for products safety. A share of such examinations can be equal to about $20 \%$ according to recommendations given by world practice [34].

Results of each inspection performed within the frameworks of the suggested model are to supplement and to expand the database which was an initial one for priorities determination. We should note that only this exact structure of the system provides consistent efficiency of control activities and gradual growth in overall quality of distributed goods. And as priority juridical persons and private entrepreneurs as well as the most unsafe goods are under constant and systemic control, including laboratory one, such goods should gradually be "washed out" from distribution and it will lead to a growth in overall consumers safety.

Conclusion. Profound analysis of the legislation and surveillance practices in the sphere of consumer products distribution in the EAEU revealed that the EAEU member states were in general committed to providing consumer products safety and to minimizing risks for people lives and health. The legislation in practically each member state envisages both product risks assessment and risk-oriented surveillance. The situation can be considered a good ground for developing a system of coordinated and mutually beneficial activities related to risk-oriented surveillance over products. Such a system would allow to make interstate relationships more confident and objective and create efficient barriers for products that are hazardous for population health but at the same time it would minimize administrative barriers for products that don't cause any grave (significant, high, and alike) risks for consumers health in the unified EAEU economic space.

Basing on principles of risk assessment as a combination including probable violation of obligatory sanitary requirements to products as well as probability and gravity of consequences such violation would lead to, we suggest a model for risk-oriented surveillance that can be applied in all EAEU member states as a methodical base for creating national models for surveillance over products.

The suggested model includes three interrelated modules:

1) Ranking activities performed by economic entities that deal with consumer products distribution as per potential risks of damage to health. Methodical support offered by the module allows to spot out such juridical persons or private entrepreneurs whose activities performed in the sphere of products manufacturing, trade, or catering don't meet sanitary requirements and cause the highest risks for consumers health; it also allows to fix periodicity of scheduled inspections which is relevant to risks.

2) Classification of products as per consumer health risks.

Methodical support offered by this module, basing on actual frequency with which sanitary requirements to products are violated and on consequences of such violations, allows to spot out such consumer products which are the most "risky" for consumers. It allows to select priority, or, in other words, the most hazardous products for examinations during scheduled inspections.

3) Creation of risk-oriented and differentiated laboratory support for scheduled control and surveillance activities.

Modules are provided with methodical support and specialized software.

The procedure was tested in the RF and Belarus; its practical feasibility has been proven. But still, unified approaches to products classification as well as risk-oriented surveillance model can function efficiently in the EAEU only if all their structural components are present. They are:

-information base for surveillance that includes formalized, verified, and structured data 
on parameters of inspected products; on cases in which obligatory requirements to products were violated; on consequences of such violations; on evidence proving that health disorders were caused exactly by hazardous factors related to products;

- methodical and mathematical tools and software that allow to process data arrays, to obtain simple and easy-to-understand statistics on results of control and surveillance activities (calculation of violation frequencies on product types in general, as per specific factors, manufacturers, etc.), as well as to perform more science-intense operations: to detect relationships within "products - damage to health" system or "risk management activities - products risk characteristics" system; to assess average and maximum expected gravity of health disorders; etc.;

- organizational structure that is provided with qualified personnel; this structure should collect, process, and analyze data, and inform all the concerned parties about obtained results.

- well-organized channels for information exchange; some participants use then to feed ini- tial data into the system (control results including laboratory tests reports, data on injuries, intoxication, diseases, complaints about products etc.), and other participants give a feedback when they "communicate" results of assessing hazards or risks related to this or that product. And informing about risks is supposed to transform into more complicated and sophisticated data exchange form, namely, risk communication.

Overall, the system of risk-oriented surveillance over products is developing quite intensely. Mutual disclosure of results obtained during control and surveillance activities, data exchange, and multi-sided informing about cases in which damage to health occurred give grounds for further development of the system and creation of barriers preventing unsafe products from entering the common EAEU market.

Funding. The research was not granted any sponsor support.

Conflict of interests. The authors state there is no any conflict of interests.

\section{References}

1. Malysheva A.G., Kozlova N.Yu., Yudin S.M. Neuchtennaya khimicheskaya opasnost' protsessov transformatsii veshchestv v okruzhayushchei srede pri otsenke effektivnosti primeneniya tekhnologii [The unaccounted hazard of processes of substances transformation in the environment in the assessment of the effectiveness of the application of technologies]. Gigiena $i$ sanitariya, 2018, vol. 97, no. 6, pp. 490-497.

2. Gmoshinskii I.V., Khotimchenko S.A. Nanotekhnologii v proizvodstve pishchevykh produktov: otsenka riskov [Nanotechnology in food production: risk assessment]. Voprosy pitaniya, 2014, vol. 83, no. S3, $174 \mathrm{p}$.

3. Poznyakovskii V.M. Geneticheski modifitsirovannye istochniki pishchi: aktual'nost' problemy, tekhnologiya sozdaniya, voprosy bezopasnosti i kontrolya [Genetically modified sources of food: a problem urgency, technology of creation safety issues and the control]. Tekhnika i tekhnologiya pishchevykh proizvodstv, 2009, vol. 14, no. 3, pp. 58-65.

4. Kamalieva L.A. Opasnye dlya zhizni ili zdorov'ya potrebitelei lekarstvennye sredstva i spirtosoderzhashchaya produktsiya [Medications and alcohol-containing products hazardous for health and life of consumers]. Aktual'nye problem ekonomiki i prava, 2011, no. 1, pp. 237-239.

5. Eriksson J., Öborn I., Olsson I.-M., Oskarsson A., Skerfving S., Eriksson J. Cadmium in food production systems: a health risk for sensitive population groups. Ambio, 2005, vol. 34, no. 4-5, pp. 344-351.

6. Khamidulina Kh.Kh., Zamkova I.V., Kasatkina T.A. Novye svedeniya o toksichnosti i opasnosti khimicheskikh i biologicheskikh veshchestv [New information on toxicity and hazard of chemical and biological substances]. Toksikologicheskii vestnik, 2006, no. 1, pp. 42-43.

7. Cardwell K.F., Henry S.H. Risk of exposure to and mitigation of effect of aflotoxin on human health: a west African example. Journal of Toxicology. Toxin Reviews, 2004, vol. 23, no. 2-3, pp. 217-247.

8. Abramova L.M. Novye dannye po biologicheskim i nvaziyam chuzherodnykh vidov v Respublike Bashkortostan [New data on biological invasions of alien species in the Republic of Bashkortostan]. Vestnik Akademii nauk Respubliki Bashkortostan, 2014, vol. 19, no. 4, pp. 16-27.

9. Avdyukhina T.I., Dovgalev A.S., Imamkuliev K.D., Konstantinova T.N., Guzeeva T.M. Novye i vozvrashchayushchiesya parazitozy. Parazitarnye bolezni, peredayushchiesya s produktami pitaniya 
[New and returning parasitosis. Parasitic diseases transmitted with food]. Infektsiya $i$ immunitet, 2012, vol. 2, no. 1-2, 350 p.

10. Koreshkov V.N., Shakkaliev A.A. O razvitii sistemy tekhnicheskogo regulirovaniya v ramkakh Evraziiskoi ekonomicheskoi integratsii [On the development of a technical regulation system in the framework of Eurasian economic integration]. Kompetentnost', 2017, vol. 144, no. 3, pp. 12-19.

11. Usmanova D.R., Kazamirov A.I. Risk-orientirovannyi podkhod v kontrol'no-nadzornoi deyatel'nosti organov ispolnitel'noi vlasti [The risk-oriented approach in control and oversight activities]. Evraziiskii yuridicheskii zhurnal, 2016, vol. 6, no. 97, pp. 69-70.

12. Bender W.J., Ayyub B.M. Risk-based cost control for construction. AACE International Transactions, 2000, $11 \mathrm{p}$.

13. Chaplinskii A.V., Plaksin S.M. Upravlenie riskami pri osushchestvlenii gosudarstvennogo kontrolya v Rossii [Risk Management in the State Control in Russia]. Voprosy gosudarstvennogo $i$ munitsipal'nogo upravleniya, 2016, no. 2, pp. 7-29.

14. EFSA Panel on Genetically Modified Organisms (GMO); Scientific Opinion on Guidance for risk assessment of food and feed from genetically modified plants. EFSA Journal 2011, vol. 9, no. 5, 2150, 37 p. Available at:www.efsa.europa.eu/efsajournal.htm._DOI: 10.2903/j.efsa.2011.2150 (07.11.2017).

15. Beltoft V., Nørby K., Annual Report of preparatory work on the toxicological studies and animal feeding studies performed under the EFSA contract OC/EFSA/GMO/2014/01, Lot 2 during the period 1/3/2017 to 27/11/2018, EFSA Supporting Publications, 2019, vol. 16, no. 2.

16. Olaru I., Waigmann E., Annual report of the EFSA Scientific Network for Risk Assessment of GMOs for 2017, EFSA Supporting Publications, 2018, vol. 15, no. 2.

17. Scott J., Chen Yu. Risk-Based Sampling: Perspective from CFSAN, USA. URL: Available at: https://www.foodprotection.org/upl/downloads/meeting/program-overview/573b2efdcffe3782270b.pdf (07.11.2017).

18. Richard O'Brien. U.S. Consumer Product Safety Commission. CPSC, Mexico City, December 2011. Available at: https://www.profeco.gob.mx/educ_div/Presentacion\%20Richard\%20O\%27Brien.pdf (07.11.2017).

19. Overview of health Canada consumer product safety program risk characterization method, 2017. Available at: https://www.canada.ca/en /health-canada/services/consumer-product-safety/legislation-guidelines/guidelines-policies/overview-health-canada-consumer-product-safety-program-risk-characterization-method.html (07.01.2019).

20. Appendix D. Food safety risk analysis. Available at: http://www1.agric.gov.ab.ca /\$Department /deptdocs.nsf/all/afs12301/\$FILE/appendix_d_risk_analysis.pdf (07.11.2017).

21. Zaitseva N.V., May I.V., Sychik S.I., Fedorenko E.V., Shevchuk L.M. Analysis of legal and methodological grounds for risk-oriented surveillance over consumer products: tasks and development prospects in the Eurasian Economic Union. Analiz riska zdorov'yu, 2017, no. 4, pp. 4-22. DOI:10.21668/health.risk/2017.4.01

22. Ul'brikht K., Dzhamankulov N. Sistema kontrolya bezopasnosti pishchevoi produktsii v Evropeiskom Soyuze i Evraziiskom ekonomicheskom soyuze [Food safety control system in the European Union and the Eurasian Economic Union]. Torgovaya politika, 2016, vol. 6, no. 2, pp. 41-84.

23. Global Burden of Disease Study 2016 (GBD 2016) Disability Weights. Available at: http://ghdx.healthdata.org/sites/default/files/record-attached-iles/IHME_GBD_ 2016_DISABILITY_WEIGHTS_3.ZIP (18.02.2019).

Gaevskiy I.V., Zaitseva N.V., May I.V., Karymbaeva S.T., Sychik S.I., Fedorenko E.V. On methodical support for risk-oriented surveillance over consumer products safety on the unified economic territory of the eurasian economic union. Health Risk Analysis, 2019, no. 1, pp. 4-16. DOI: 10.21668/health.risk/2019.1.01.eng

Received: 15.02 .2019

Accepted: 10.03 .2019

Published: 30.03.2019 
UDC $51-76$

DOI: 10.21668/health.risk/2019.1.02.eng

\title{
ASSESSING RISKS OF ADVERSE CLINICAL COURSE AND OUTCOME OF AN INFECTIOUS DISEASE WITH MATHEMATICAL MODELING OF EXPOSURE TO ENVIRONMENTAL FACTORS ON THE EXAMPLE OF ALUMINUM OXIDE
}

\author{
P.V. Trusov ${ }^{1}$, N.V. Zaitseva ${ }^{2}$, V.M. Chigvintsev ${ }^{1,2}$ \\ ${ }^{1}$ Perm National Research Polytechnic University, 29 Komsomolskiy prospect, Perm, 614990, Russian Federation \\ ${ }^{2}$ Federal Scientific Center for Medical and Preventive Health Risk Management Technologies, \\ 82 Monastyrskaya Str., Perm, 614045, Russian Federation
}

\begin{abstract}
Our research goal was to create a mathematical model that described anti-viral immune response regulation taking into account influence exerted by exposure to variable chemical factors. We analyzed a body response to an infection taking into account innate and adaptive immunity mechanisms. This created mathematical model helps to describe spatial distribution of immune and infectious agents in various organs and systems due to allowing for time lags occurring during interactions between different components participating in the process. The mathematical model is a system of ordinary differential equations with a retarded argument; separate addends of the model describe velocity properties of the processes that produce their effects on the development of an infectious disease. We suggest an algorithm for conducting an experiment aimed at identifying certain parameters related to influence exerted by chemical factors on interaction between the neuroendocrine and immune systems. We calculated dynamics in parameters of the immune and neuroendocrine systems when a viral infection occurs under experimental exposure to aluminum oxide. The suggested approach is applied within the concept of a multi-level human body model that takes into account interactions between systems and functional state of organs that are being examined under exposure to adverse factors of variable genesis. The conducted research provides a qualitative conception about causes that explain quantitative changes in a viral agent when an immune response occurs in a body under exposure to variable factors. This approach can be applied to adjust parameters of existing population models, spread and clinical course of different infections, and to draw up a long-term forecast of an epidemiologic situation which is necessary when risks of infectious diseases are analyzed, including those occurring when a body is exposed to adverse environmental factors.

Key words: mathematical model, dynamic system, viral disease, innate immunity, adaptive immunity, neuroendocrine regulation.
\end{abstract}

Introduction. Nowadays an issue of describing interrelations in adaptive systems which modify their functioning in order to preserve their optimal state under changing outer conditions is of great interest to researchers

who study neuroendocrine regulation and immune mechanisms $[1,2]$. Works published in the field focus on various sings of mutual regulatory influences exerted by the systems being considered on each other [3,4]. Some

(C) Trusov P.V., Zaitseva N.V., Chigvintsev V.M., 2019

Petr V. Trusov - Doctor of Physical and Mathematical Sciences, Professor, Head of Mathematic Modeling of Systems and Processes Department, Chief Researcher (e-mail: tpv@matmod.pstu.ac.ru; tel.: +7 (342) 239-16-07; ORCID: https://orcid.org/0000-0001-8997-5493).

Nina V. Zaitseva - Member of the Russian Academy of Sciences, Doctor of Medical Sciences, Professor, Director (e-mail: znv@)fcrisk.ru; tel.: +7 (342) 237-25-34; ORCID: https://orcid.org/0000-0003-2356-1145).

Vladimir M. Chigvintsev - Researcher at Mathematic Modeling of Systems and Processes Department, post-graduate student at Mathematic Modeling of Systems and Processes Department (e-mail: cvm@fcrisk.ru; tel.: +7 (342) 237-18-04; ORCID: https://orcid.org/0000-0002-0345-3895). 
research dwells on neuroendocrine regulation of the immune system $[5,6]$ and controlling influence exerted by the immune system, for example, via cytokines production, both on itself and on the neuroendocrine regulatory loop [7, 8]. Most experts in the field believe neuroendocrine and immune regulatory loops are a unified "super"-regulatory metasystem $[9,10]$ which coordinates a complicated multi-level regulatory process in a human body. The immune system protects a body from multiple threats, including viral infections; losses occurring due to such infectious make a considerable contribution into overall damages done to population by various health disorders and are a great medical and social problem [11].

Technogenic environmental factors can cause pathomorphism and lead to deteriorated clinical course and outcome of infectious diseases $[12,13]$. Technogenic processes exert influence on regulatory (immune and neuroendocrine) systems; thus, for example, it was shown $[14,15]$, that technogenic chemical factors exerted negative impacts on functioning of the said systems.

Observation techniques or an experimental approach with subsequent statistical processing which are conventionally applied to assess functional disorders in the immune and neuroendocrine system, in spite of all their significance, don't fully allow to analyze mechanisms and assess consequences caused by an effect occurring when functional disorders accumulate in body systems. It is due to limitations which exist in choice of representative groups, complications related to identification and detection of basic factors, and substantial material costs which are required for organizing and conducting experiments.

Mathematical modeling seems to be one of the most efficient approaches to finding an optimal strategy for examining as well as predicting clinical course of virus diseases. This approach allows to save time and resources required for solving the abovementioned tasks. Mathematical models make it possible to analyze influence exerted by various factors and their combinations at an individual and population level. An example of such models is mathematical prediction models which describe correlation between human health and environmental factors $[16,17,18]$.

Our research goal was to develop approaches to assessing body responses to an infectious disease taking into account interaction between the immune and neuroendocrine system under exposure to aluminum oxide and with functional disorders accumulating in a body.

Data and methods. We worked out an experimental procedure for examining negative influences exerted by chemical agents on interaction between components of the immune and neuroendocrine systems. This procedure allows to determine impacts exerted by various factors on activity of immune cells that protect a body from infections.

We chose aluminum oxide as an influencing factor in this work. Technogenic pollution with metals is a widely spread problem on industrially developed territories; peculiarities related to influences exerted by such contaminants on population health are their ability to change immune cells functioning, either inhibiting or stimulating them as well as controlling proteins produced by such cells. Aluminum compounds produce inhibiting effects on functions performed by immune cells ( $\mathrm{T}$ - and B-lymphocytes and macrophages) and on controlling proteins production as well as ratio of immune cells quantity.

Our experiment was accomplished on an undivided population of immune cells which included T-helpers (CD3/4), B-cells (CD19/22), NK-cells (CD16/56), and cytotoxic T lymphocytes (CD3/8); the population was extracted from a peripheral blood sample. We examined a combine response given by the immune cells population to impacts, but to assess functionality of each cells type, we chose a specific parameter that reflected functions of only one type of immune cells. 
Influences exerted by controlling elements, such as intrleukin-1, interleukin-2, or hydrocortisone, were considered to be contributors that induced (regulated) work performed by immune cells; occurrence of viruses was another contributor (we applied a solution based on hemagglutinin and concanavalin as a viral load simulator due to its ability to induce similar responses from the immune system). Changes that occurred in functional activity of the examined immune cells population were assessed as per production of specific controlling proteins.

Concentration of a viral load simulator (a universal mitogen based on hemagglutinin and concanavalin) applied in experimental research was within $10-1,000 \mu \mathrm{g} / \mathrm{ml}$ range. Operating levels of interleukin-1 were determined as per data on changes in cytokine concentration in a healthy body. Normally, interleukin-1 contents should be within $0-10 \mathrm{pg} / \mathrm{ml}$. Interleukin-2 concentrations were determined as per data obtained for healthy people and existing standards; they amounted to $10 \mathrm{pg} / \mathrm{ml}$ and $100 \mathrm{pg} / \mathrm{ml}$ respectively. Standard hydrocortisone concentration is $138-635 \mathrm{nmol} / \mathrm{l}$. We analyzed impacts exerted by two aluminum concentrations, $0.01 \mathrm{mg} / 1$ and $0.1 \mathrm{mg} / 1$, its maximum permissible concentration in water being equal to $0.2 \mathrm{mg} / \mathrm{l}$.

We determined how many experiments we required judging from the necessity to take into account impacts exerted by all the contributors, namely interleukin-1, interleukin-2, hydrocortisone, aluminum oxide, and viral load. 16 experiments are a halfreplicate of a complete factor experiment for 5 factors. Below one can see the overall view of a sought function that describes impacts exerted by the considered factors on marker proteins production by cells:

$$
\begin{aligned}
& y\left(x_{i}\right)=b_{0}+b_{1} x_{1}+b_{2} x_{2}+b_{3} x_{3}+b_{4} x_{4}+b_{5} x_{5}+ \\
& +b_{1,4} x_{1} x_{4}+b_{2,4} x_{2} x_{4}+b_{3,4} x_{3} x_{4}+b_{1,5} x_{1} x_{5}+ \\
& +b_{2,5} x_{2} x_{5}+b_{3,5} x_{3} x_{5}+b_{4,5} x_{5} x_{4}+b_{1,4,5} x_{1} x_{5} x_{4}+ \\
& +b_{2,4,5} x_{2} x_{5} x_{4}+b_{3,4,5} x_{3} x_{5} x_{4}
\end{aligned}
$$

where $y\left(x_{i}\right)$ is a concentration of a marker protein that characterizes functional activity of immune cells;

$b_{j}$ are sought coefficients of the model;

$x_{1}$ is a concentration of viral load simulator;

$x_{2}$ is interleukin- 1 concentration;

$x_{3}$ is interleukin-2 concentration;

$x_{4}$ is hydrocortisone concentration;

$x_{5}$ aluminum oxide concentration.

All the parameters were recalculated as per their maximum value obtained during the experiment; as a result, all the variables in the mathematical model are of the same order. Maximum interferon-gamma concentration amounts to $30.62[\mathrm{pg} / \mathrm{ml}]$ and interleukin, $8[\mathrm{pg} / \mathrm{ml}]$.

We applied a structural scheme shown in Figure 1 to describe interaction between the immune and neuroendocrine systems under exposure to aluminum oxide and with functional disorders accumulating in a body. The scheme is a set of interrelated immune and neuroendocrine system elements which are the most significant components in a body response to a virus invasion. The models takes into account functional state of organs being considered.

As we describe interactions between the immune and endocrine system which are very complicated we introduce certain simplifying assumptions into the design of our model. Cells and viruses populations are assumed to be evenly spread over the epithelial layer of a target organ at any moment. We also assume that speed of changes in any variable in the model is determined by the current values of all the variables. At present we assume that the basic processes which regulate immune protection dynamics take place in three local volumes: brains (hypophysis and hypothalamus), abdominal cavity (adrenals), and a target organ. Interaction between these three local volumes occurs with a time lag.

Protection mechanisms are activated after macrophages have removed cells affected by a virus, simultaneously information molecules of (cytokine) interleukin-1 are synthesized [19]. 


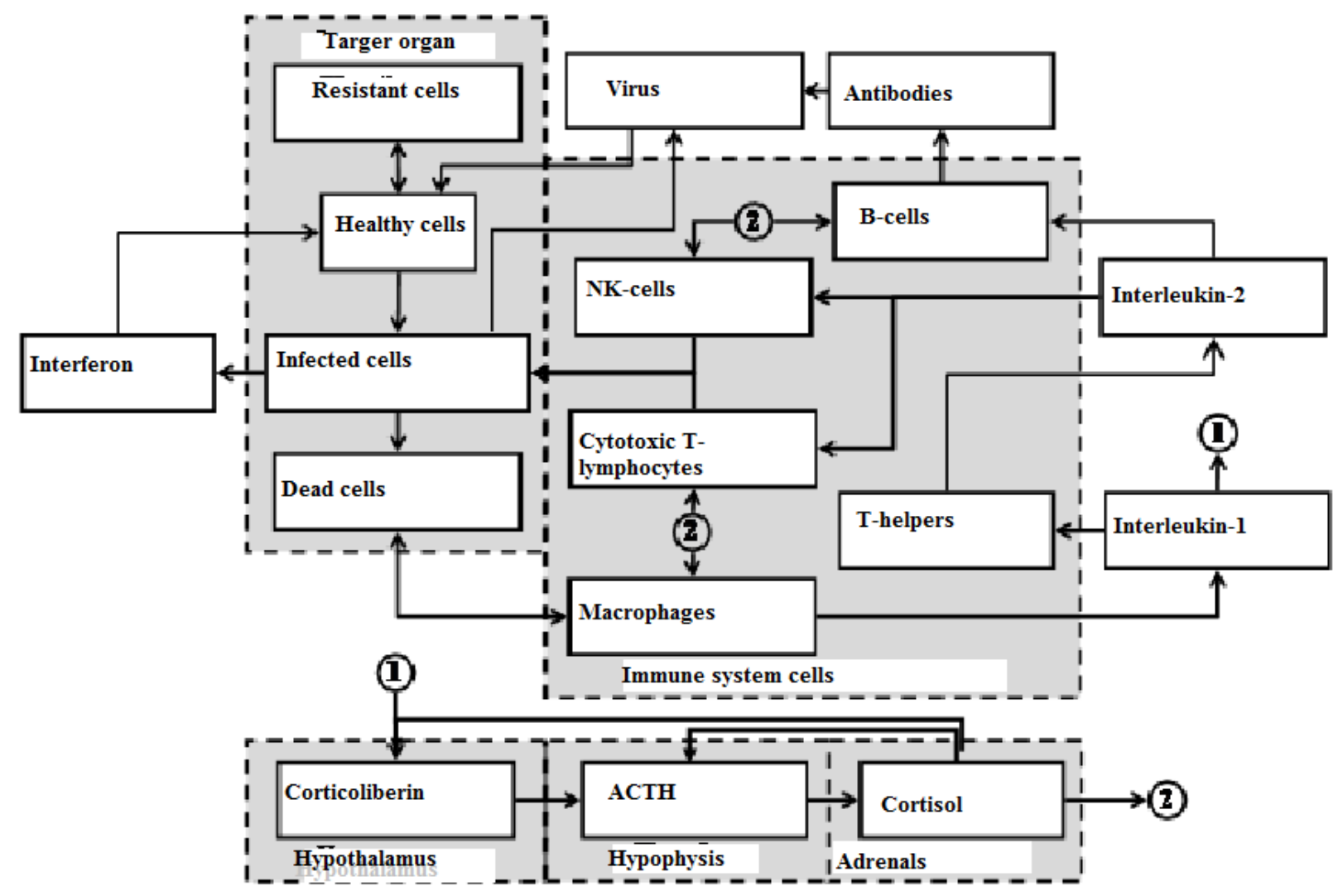

Figure 1. A conceptual scheme showing how the immune and neuroendocrine systems function in case a virus infection occurs

As interleukin-1 concentration in blood increases, it makes for $\mathrm{T}$-helpers producing interleukin-2 and stimulates specific receptors in the hypothalamus to produce corticoliberin, a release hormone. Corticoliberin influences the adenohypophysis and causes adrenocorticotropic hormone (ACTH) secretion [18]. When penetrating blood, ACTH stimulates the adrenals to produce hydrocortisone; increased concentration of this hormone inhibits ACTH secretions and blocks interleukin-1 production as per negative feedback mechanism.

Regulatory impacts exerted by interleukin-2 are aimed at NK-cells [35], cytotoxic T-lymphocytes [15] and B-cells [2]. Basic NK-cells function is related to infected cells elimination at early stages of a body protecting against virus infections. In our work we allow for inhibiting effects exerted on NK-cells by hydrocortisone $[23 ; 24]$ and stimulating influence by interleukin-2 [25].

Infected cells produce interferon and it is another mechanism of primary anti-virus body protection [26, 27]. There are basic mechanisms of specific acquired immune response: B-cells produce antibodies [28] which bind free viruses, and cytotoxic T-lymphocytes destroy cells infected with viruses [29]. Hydrocortisone inhibits antiviral activity of the examined cells.

Basing on the above-given interaction scheme we can describe a mathematical model for the regulation mechanism comprising elements of the immune and endocrine system with the help of the designed model which is a system consisting of 18 ordinary first-order differential equations with a retarded argument (2): 


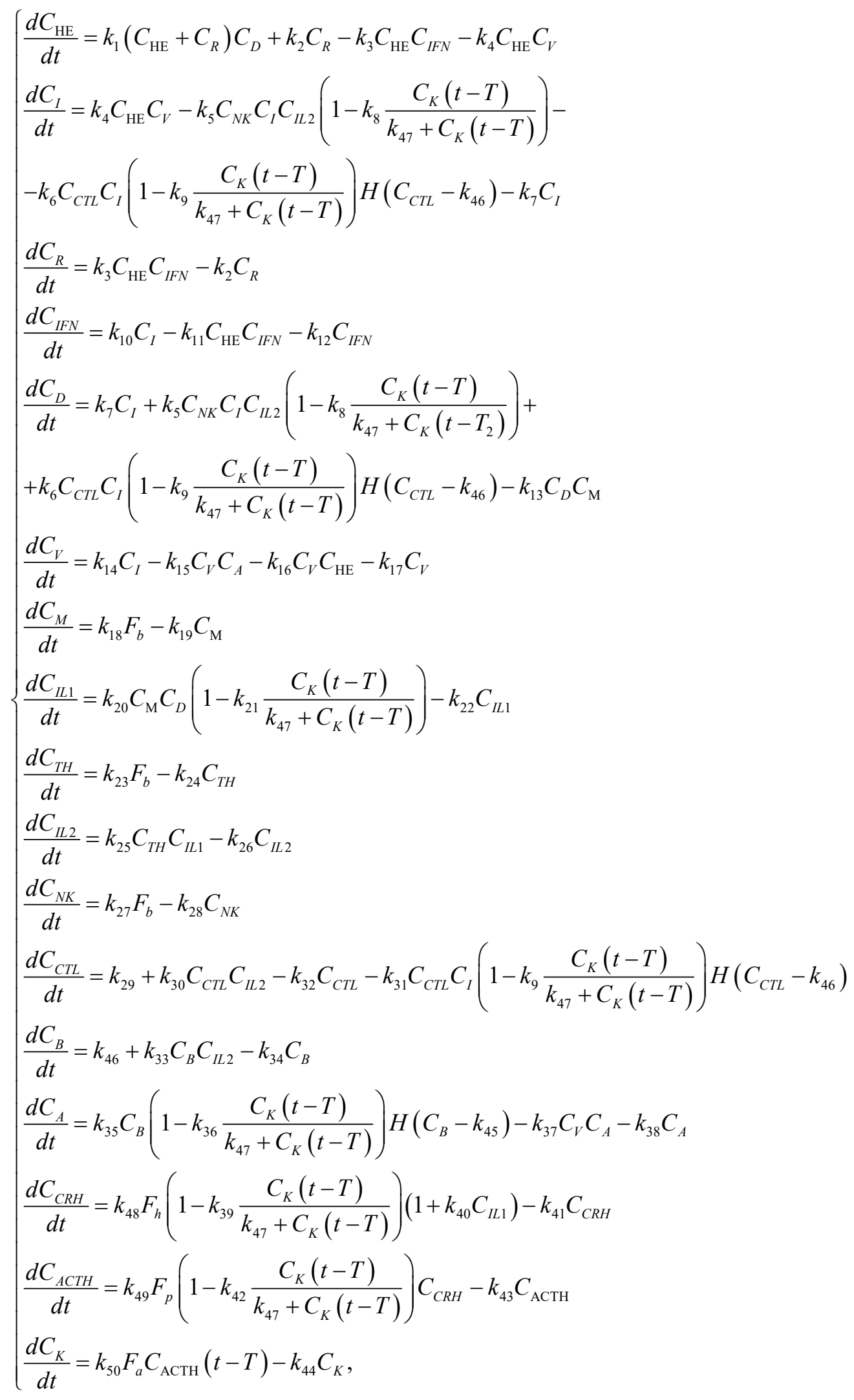

where

$C_{R}$ is a number of resistant cells in a target

$C_{H E}$ is number of healthy non-resistant cells in a target organ, [cells];

$\mathrm{k}_{\mathrm{i}}$ are quotients of a model; organ, [cells];

$C_{D}$ is a number of dead cells in a target organ, [cells]; 
$C_{I F N}$ is interferon concentration, [IU/ml];

$C_{V}$ is viruses concentration, [copies $/ \mathrm{ml}$;

$C_{I}$ is a number of infected cells in a target organ, [cells];

$C_{N K}$ is NK-cells (natural killers) concentration, [cells $/ \mathrm{ml}$;

$C_{I L 2}$ is interleukin-2 concentration, $[\mathrm{pg} / \mathrm{ml}]$;

$C_{K}$ is hydrocortisone concentration, [nano$\operatorname{gram} / \mathrm{ml}$;

$T$ is time lag, [minutes];

$C_{C T L}$ is cytotoxic T-lymphocytes concentration, [cells $/ \mathrm{ml}$;

$C_{M}$ is macrophages (monocytes) concentration, [cells $/ \mathrm{ml}]$;

$C_{A}$ is antibodies concentration, $[\mathrm{mIU} / \mathrm{ml}]$;

$F_{b}$ is marrow functional capacity, synthesizing function, [dimensionless value];

$C_{I L l}$ is interleukin-1 concentration, $[\mathrm{pg} / \mathrm{ml}]$;

$C_{T H}$ is T-helpers concentration, [cells $/ \mathrm{ml}$;

$C_{B}$ is B-cells concentration, [cells $/ \mathrm{ml}$;

$C_{C R H}$ is corticoliberin concentration, $[\mathrm{pg} / \mathrm{ml}]$;

$F_{h}$ is hypothalamus functional capacity, synthesizing function, [dimensionless value];

$C_{A C T H}$ is adrenocorticotropic hormone (ACTH) concentration, [picogram $/ \mathrm{ml}(\mathrm{pg} / \mathrm{ml})$ ];

$F_{p}$ is hypophysis functional capacity, synthesizing function, [dimensionless value];

$F_{a}$ is adrenals functional capacity, synthesizing function, [dimensionless value].

Interactions between cells populations and body information molecules are based on the clonal selection theory (Burnet theory according to which cells clones (B-cells) occur in a body; these cells are specific to different viruses and a virus selectively contacts a corresponding clone thus stimulating it to produce antigens), mass action law (reactions speeds are proportionate to substances concentration product), interaction characteristics and Markov's death and recovery processes.

The model parameters were indentified on the basis of experimental data obtained during research on a process of a body being infected with a flu virus; values for the model parameters are given in Table 1.

As all the equations in the model are complicated and non-linear, it becomes more difficult to obtain analytical solutions with it.
To solve the differential equation system, we apply implicit numerical technique by RungeKutta of the third order.

Results and discussion. We analyzed the results of our experiment during which we assessed effects produced by various factors on interferon-gamma production and determined that the greatest influence was exerted by a viral load simulator. Average standardized value for interferon-gamma amounted to $0.225 \pm 0.058$ under low influence exerted by a viral load simulator, but when this influence was significant, it amounted to $0.323 \pm 0.086$ (there was an authentic discrepancy between the obtained average values, $p<0.05$ ). We can conclude that interferon-gamma is synthesized due to stimulating effects produced by a viral load simulator and it is well in line with literature data.

Influence exerted by low concentrations of a viral load simulator on interferon-gamma production is significantly modified by effects produced by hydrocortisone; this phenomenon corresponds with literature data on qualitative effects produced by hydrocortisone [39]. Average standardized value for interferongamma concentration amounts to $0.277 \pm 0.098$ when influence exerted by a viral load simulator is low and so is hydrocortisone concentration; but when hydrocortisone concentration is high, interferon-gamma concentration is equal to $0.173 \pm 0.065$ (there was an authentic discrepancy between the obtained average values, $\mathrm{p}<0.05)$. These values are shown on Figure 2 . This observed discrepancy can be an evidence that hydrocortisone has inhibiting effects under low values of a factor that influences immune cells. When a viral load simulator was high, we didn't reveal any significant effects produced by hydrocortisone.

Interferon-gamma is produced in a human body primarily by infected cells in a target organ and NK-cells. The performed experiment revealed that interferon-gamma production by NK-cells was stimulated by a controlling protein, namely interleukin-2. The obtained results are in line with literature data. Average standardized interferon-gamma concentration amounted to $0.193 \pm 0.049$ under insignificant influence exerted by interleukin-2, but when 
Table 1

Parameters of the mathematical model that describes interactions between the immune and endocrine systems under a virus infection

\begin{tabular}{|c|c|c|c|c|c|}
\hline Parameter & Value & Source & $\begin{array}{c}\text { Parame- } \\
\text { ter }\end{array}$ & Value & Source \\
\hline$k_{1}$ & $2.35 * 10^{-11}[1 /$ cells $*$ day $]$ & {$[30]$} & $k_{27}$ & $1.1 * 10^{14}[$ cells $/ \mathrm{ml} *$ day $]$ & \\
\hline$k_{2}$ & $0.98[1 /$ day $]$ & [31] & $k_{28}$ & 0.11 [1/day] & \\
\hline$k_{3}$ & $1.1 * 10^{-17}[\mathrm{ml} / \mathrm{IU} *$ day $]$ & [32] & $k_{29}$ & $4 * 10^{15}[$ cells $/ \mathrm{ml} *$ day $]$ & [31] \\
\hline$k_{4}$ & $2 * 10^{-12}[\mathrm{ml} /$ copies*day $]$ & {$[31]$} & $k_{30}$ & $4.15[\mathrm{ml} / \mathrm{pg}$ *day] & {$[31]$} \\
\hline$k_{5}$ & $2.5 * 10^{-17}\left[\mathrm{ml}^{2} /\right.$ cells*pg*day $]$ & & $k_{31}$ & $1.6^{*} 10^{-11}\left[1 /\right.$ cells $^{*}$ day $]$ & [32] \\
\hline$k_{6}$ & $6.6^{*} 10^{-18}[\mathrm{ml} /$ cells*day $]$ & {$[32]$} & $k_{32}$ & $0.4[1 /$ day $]$ & [31] \\
\hline$k_{7}$ & $1.5[1 /$ day $]$ & [33] & $k_{33}$ & $5.75\left[\mathrm{ml} / \mathrm{pg}{ }^{*}\right.$ day $]$ & [31] \\
\hline$k_{8}$ & 0.5 [dimensionless] & & $k_{34}$ & 0.4 [1/day] & {$[31]$} \\
\hline$k_{9}$ & 0.5 [dimensionless] & & $k_{35}$ & $7.56 * 10^{12}[\mathrm{mIU} /$ cells $]$ & [31] \\
\hline$k_{10}$ & $3.2 * 10^{6}\left[\mathrm{IU} / \mathrm{cell}^{*} \mathrm{ml}{ }^{*}\right.$ day $]$ & & $k_{36}$ & 0.5 [dimensionless] & \\
\hline$k_{11}$ & $1.01 * 10^{-10}[1 /$ cells $*$ day $]$ & [32] & $k_{37}$ & $8.6^{*} 10^{-10}[\mathrm{ml} /$ copies*day $]$ & {$[32]$} \\
\hline$k_{12}$ & 8 [1/day] & [32] & $k_{38}$ & $0.043[1 /$ day $]$ & [31] \\
\hline$k_{13}$ & $10^{-14}\left[\mathrm{ml} /\right.$ cells*day $^{2}$ & & $k_{39}$ & 0.5 [dimensionless] & \\
\hline$k_{14}$ & 510 [copies/ml*cells*day] & [33] & $k_{40}$ & $0.002[\mathrm{ml} / \mathrm{pg}]$ & \\
\hline$k_{15}$ & $8.6^{*} 10^{-10}\left[\mathrm{ml} / \mathrm{mIU}{ }^{*}\right.$ day $]$ & [43] & $k_{41}$ & $3.767[1 / \mathrm{day}]$ & {$[36]$} \\
\hline$k_{16}$ & $6.1 * 10^{-12}[1 /$ cells $*$ day $]$ & [32] & $k_{42}$ & 0.5 [dimensionless] & \\
\hline$k_{17}$ & 1.7 [1/day] & [32] & $k_{43}$ & 0.7572 [1/day] & {$[37]$} \\
\hline$k_{18}$ & $3 * 10^{9}[$ cells $/ \mathrm{ml} *$ day $]$ & [31] & $k_{44}$ & 0.1972 [1/day] & [37] \\
\hline$k_{19}$ & 0.03 [1/day] & [31] & $k_{45}$ & $1.8139 * 10^{20}[$ cells $/ \mathrm{ml}]$ & \\
\hline$k_{20}$ & $2.94 * 10^{-19}\left[\mathrm{pg} / \mathrm{cells}^{2} *\right.$ say $]$ & [34] & $k_{46}$ & $0.4 * 10^{16}[$ cells $/ \mathrm{ml}]$ & [31] \\
\hline$k_{21}$ & 0.5 \{dimensionless] & & $k_{47}$ & $3.055[\mathrm{ng} / \mathrm{ml}]$ & {$[38]$} \\
\hline$k_{22}$ & 0.1245 [1/day] & [35] & $k_{48}$ & $7.659[\mathrm{pg} / \mathrm{ml}]$ & {$[36]$} \\
\hline$k_{23}$ & $5.8 * 10^{3}[\mathrm{cells} / \mathrm{ml}$ day $]$ & & $k_{49}$ & $21[\mathrm{pg} / \mathrm{ml}]$ & {$[37]$} \\
\hline$k_{24}$ & 0.0058 [1/day] & & $k_{50}$ & $3.055[\mathrm{ng} / \mathrm{ml}]$ & {$[38]$} \\
\hline$k_{25}$ & $3.28 * 10^{-7}[\mathrm{ml} /$ cells $*$ day $]$ & & $\mathrm{T}$ & 0.0132 [day] & [38] \\
\hline$k_{26}$ & $0.248[1 /$ day $]$ & & & & \\
\hline
\end{tabular}

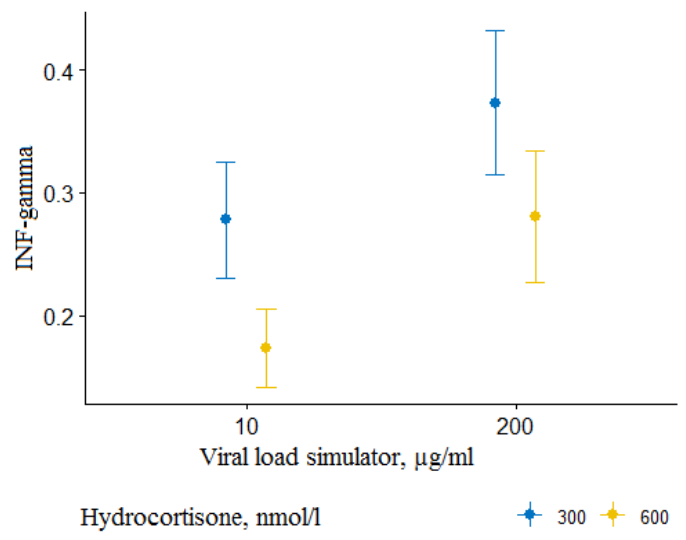

Figure 2. Average standardized interferon-gamma concentrations with error of mean under different concentration of a viral load simulator taking into account effects by hydrocortisone

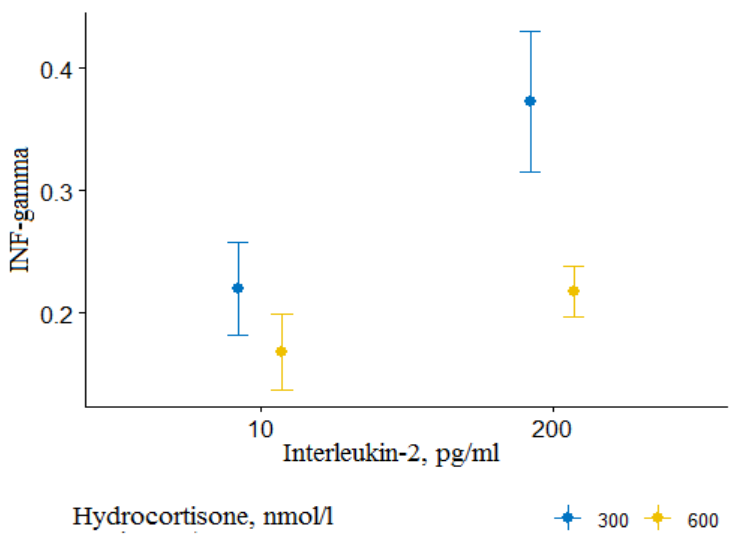

Figure 3. Average standardized interferon-gamma concentrations with error of mean under different concentration of interleukin-2 taking into account effects by hydrocortisone 
this influence was high, it was equal to $0.289 \pm 0.074$ (there was an authentic discrepancy between the obtained average values, $p<0.05$ ).

As it is not the case with a viral load simulator, hydrocortisone produces significant effects when interleukin-2 concentration is high. This observed discrepancy can be explained by the following: when we consider a viral load simulator, hydrocortisone inhibits immune reaction at the initial stage in the process thus preventing the overall chain of protective reactions in a body from activating as a virus occurs in small quantities and it is not necessary to waste energy accumulated in a body. But if interleukin-2 occurs in high concentrations in a body, it can be a sign that all the protective mechanisms are activated. In this case hydrocortisone controls interferongamma production in order to keep a body response to an infection within standardized limits. If the immunity exceeds these limits, interferon-gamma can damage healthy cells thus making a disease even worse and wasting greater amounts of energy.

Average standardized interferon-gamma concentration amounted to $0.372 \pm 0.14$ under great influence exerted by interleukin- 2 and low hydrocortisone concentration; but when hydrocortisone concentration was high, interferon-gamma concentration was equal to $0.217 \pm 0.048$ (there was an authentic discrepancy between the obtained average values, $\mathrm{p}<0.05$ ); these data are shown on Figure 3 . Low hydrocortisone concentrations don't have any significant influence on interferon-gamma production stimulated by interleukin-2.

We applied the least squares method (Statistica 6.0 software) to identify parameters of the model that described effects produced by various factors (1). To test whether the model was relevant to experimental data, we applied dispersion analysis, and the obtained model had the following characteristics: $\mathrm{R}^{2}=0.187$ and $p=0.002$. We simplified the obtained equation by dropping summands which didn't make any authentic contribution into the value for interferon-gamma concentration; this was done basing on Akaike test. We also dropped summands with low influences basing on the as- sessment of their elasticity coefficient. The equation (1), taking into account the obtained quotients values, can be given as follows:

$$
\begin{aligned}
y\left(x_{i}\right) & =0,35+x_{1}\left(0,29 x_{4}-0,32\right)+ \\
& +x_{3} x_{5}\left(0,72 x_{4}-0,56\right),
\end{aligned}
$$

where $y\left(x_{i}\right)$ is standardized interferon-gamma concentration, and interferon-gamma characterizes functional activities performed by immune cells;

$x_{1}$ is standardized concentration of a viral load simulator;

$x_{3}$ is standardized interleukin-2 concentration;

$x_{4}$ is standardized hydrocortisone concentration;

$x_{5}$ is standardized aluminum oxide concentration.

The obtained relationship allows to adjust $k_{10}$ quotient in the mathematical model (2). This adjustment allows to take into account influence exerted by aluminum oxide on an infectious process.

Figure 4 shows the results obtained via modeling three different aluminum oxide concentrations. A discrepancy in solutions to the equations systems occurs at the adaptive response stage. The obtained results revealed that exposure to aluminum oxide was at its maximum (concentration was equal to $1 \mathrm{mg} / \mathrm{l}$ ), a body fought against a virus infection quite intensely but significant damage was done to it in the process. When aluminum oxide concentration was average $(0.1 \mathrm{mg} / \mathrm{l})$, dynamics of changes in flu viruses concentration corresponded to a typical average clinical course of the disease. But when exposure to an external factor was minimal (concentration was equal to $0.01 \mathrm{mg} / \mathrm{l}$ ), the disease lasted longer but lesser damage was done to a body.

In case aluminum oxide significantly stimulates interferon-gamma production by NK-cells, it allows a greater number of cells in a target organ to simultaneously become resistant. It leads to a decrease in a number of healthy cells which are used by viruses for infecting. This fact makes the disease shorter but 
doesn't change maximum damage done to a target organ; we chose a virus for our model identification for which the upper respiratory tracts were such an organ.

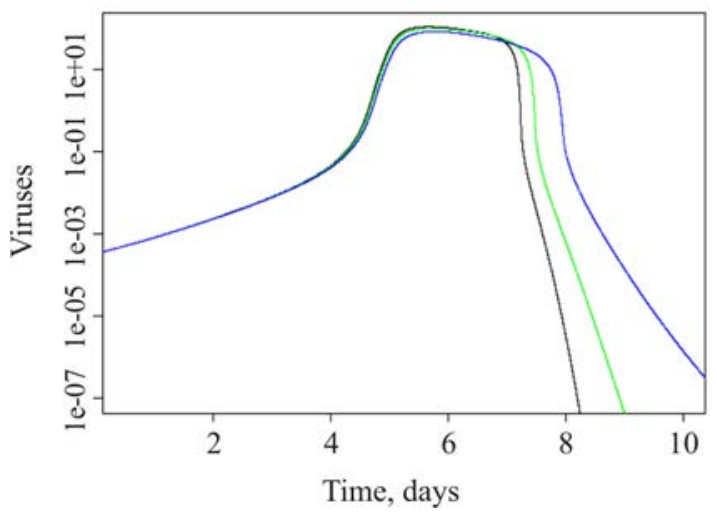

$a$

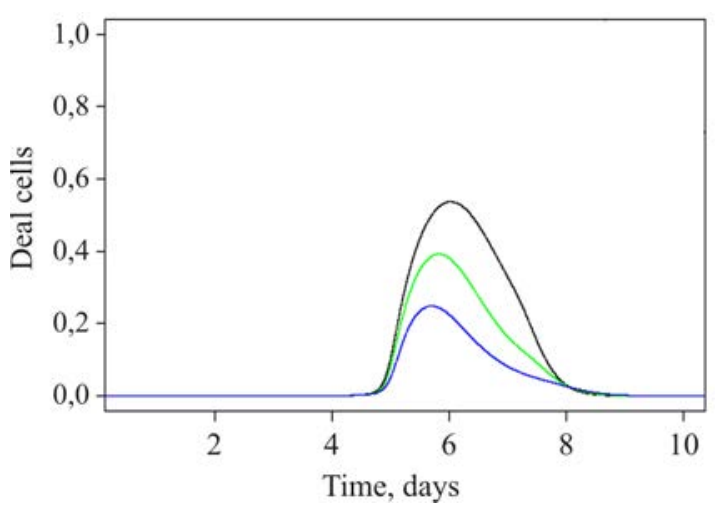

$b$

Figure 4. a) Relationship between viruses concentrations in a body and time under different aluminum concentrations $b$ ) relationship between damage to a target organ and time under different aluminum concentrations (blue line corresponds to aluminum oxide concentration equal to $0.01 \mathrm{ml} / \mathrm{l}$; green line, $0,1 \mathrm{ml} / 1$; black line, $1 \mathrm{mg} / \mathrm{l}$ )

We assessed discrepancies in average interleukin-8 concentrations under different levels of influencing factors and revealed that interleukin-1 exerted the most significant influence. Average standardized interleukin-8 concentration amounted to $0.414 \pm 0.046$ under insignificant influence exerted by interleukin-1; but if this influence was great, it was equal to $0.493 \pm 0.047$ (there was an authentic discrepancy between the obtained average values, $\mathrm{p}<0.05)$. We can conclude that interleukin-8 synthesis that characterizes NK-cells functional capabilities is stimulated by interleu- kin-1 and it is in line with literature data [40]. Influence exerted by low interleukin-1 concentrations on interleukin-8 production is significantly modified by effects produced by hydrocortisone. This phenomenon corresponds to literature data on qualitative influence exerted by hydrocortisone on NK-cells functionality [41]. Average standardized interleukin-8 concentration amounted to $0.448 \pm 0.08$ under insignificant influence exerted by interleukin-1 and low hydrocortisone concentration; but if hydrocortisone concentration was high, interleukin-8 concentration amounted to $0.38 \pm 0.049$ (there was an authentic discrepancy between the obtained average values, $\mathrm{p}<0.05)$. These values are given on Figure 5. This observed discrepancy can be an evidence that hydrocortisone produces inhibiting effects on immune cells when an influencing factor occurs in low concentrations. We didn't reveal any significant influence exerted by hydrocortisone under high interleukin-1 concentration.

This observed discrepancy in produced effects can be explained by the following: hydrocortisone inhibits immune reaction at the initial stage in the process thus preventing the overall chain of protective reactions in a body from activating as a virus occurs in small quantities and it is not necessary to waste energy accumulated in a body.

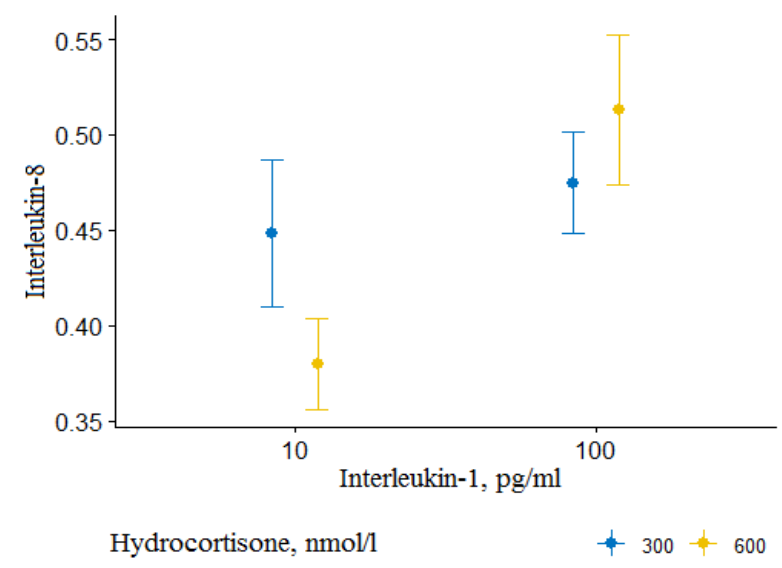

Figure 5. Average standardized interleukin-8 concentrations with error of mean under different concentration of interleukin-1 taking into account effects by hydrocortisone 
Aluminum oxide exerts similar influence on interleukin-8 production under exposure to interleukin-1. Average standardized interleukin8 concentration amounted to $0.453 \pm 0.082$ under low interleukin-1 influence and low aluminum oxide concentration; but if aluminum oxide concentration was high, interleukin- 8 concentration was equal to $0.374 \pm 0.042$ (there was an authentic discrepancy between the obtained average values, $\mathrm{p}<0.05)$. These values are shown on Figure 6.

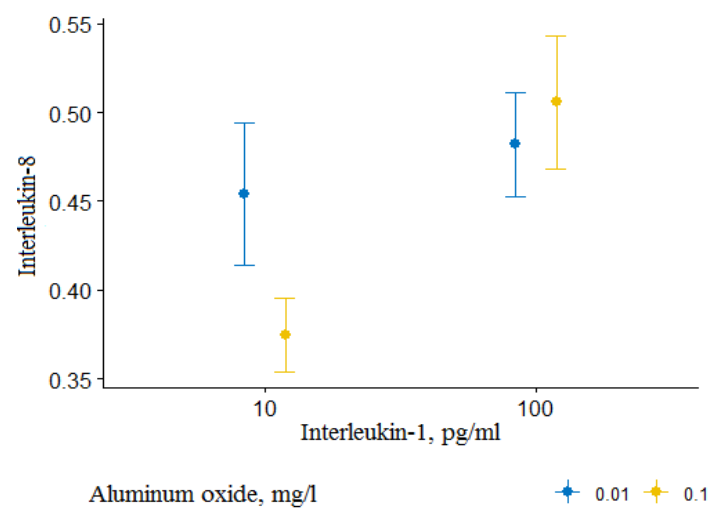

Figure 6. Average standardized interleukin-8 concentrations with error of mean under different concentration of interleukin- 1 taking into account effects by aluminum oxide

We applied the least squares method (Statistica 6.0 software) to identify parameters of the model (1). The obtained equation, taking into account new quotients values, can be given as follows:

$$
y\left(x_{i}\right)=0,35+x_{2}\left(0,11-0,13 x_{4}-0,11 x_{5}\right),
$$

where $y\left(x_{i}\right)$ is standardized interleukin- 8 concentration, and interleukin- 8 characterizes functional capabilities of immune cells;

$x_{2}$ is standardized interleukin-1 concentration;

$x_{4}$ is standardized hydrocortisone concentration;

$x_{5}$ is standardized aluminum oxide concentration.

The obtained relationship allows to adjust parameters of changes in infected cells quan- tity under an immune response in the system of equations (2). The summand $k_{5} C_{N K} C_{I} C_{I L 2}$ in the equation (2.2) describes destruction of infected cells in a target organ by NK-cells without new viruses occurrence.

To assess what influence was produced on solutions to the system of equations by effects produced by aluminum oxide on NK-cells functional capabilities, we applied a function with an adjusted quotient $k_{5}$ together with the previously obtained relationship (4). Figure 7 shows results of modeling for three different aluminum oxide concentrations.
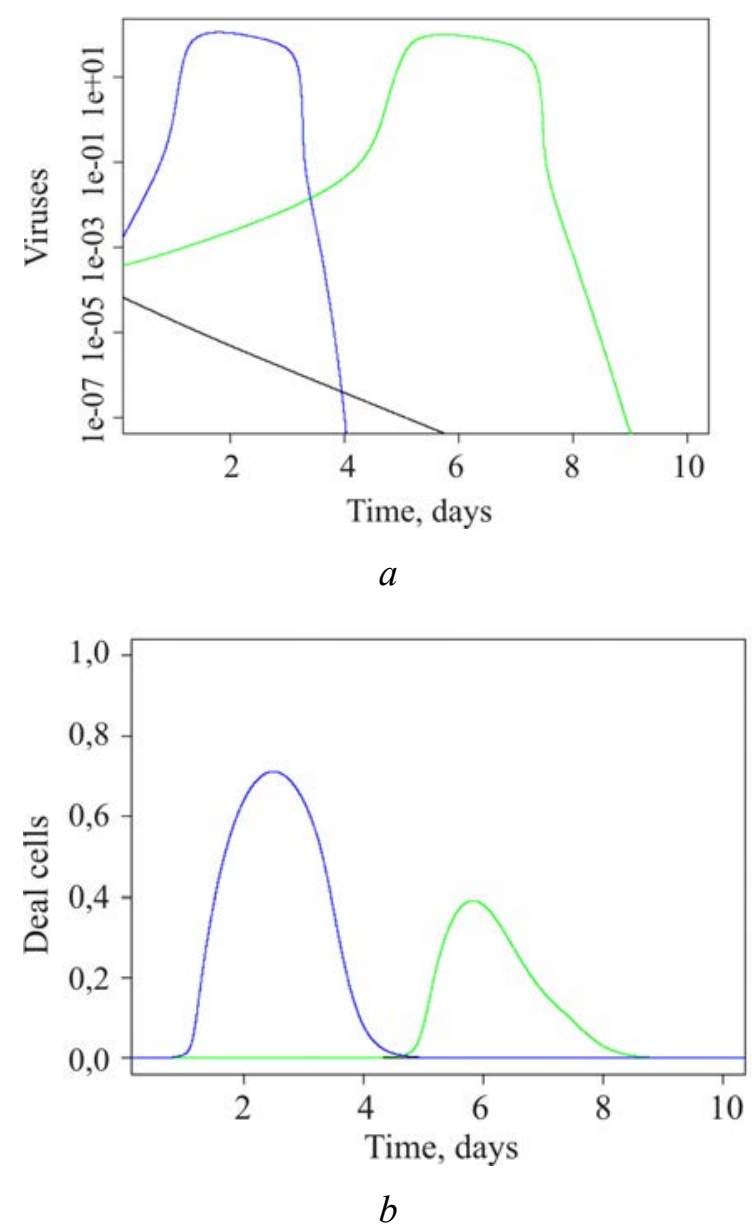

Figure 7. a) the relationship between viruses concentration in a body and time under different aluminum concentrations, b) the relationship between damage done to a target organ and time under different aluminum concentrations (the black line corresponds to aluminum oxide concentration equal to $0.01 \mathrm{mg} / 1$; the green line, $0.1 \mathrm{mg} / \mathrm{l}$; the blue line, $1 \mathrm{mg} / \mathrm{l}$ ) 
The obtained results revealed that when aluminum concentration was minimal $(0.01 \mathrm{mg} / \mathrm{l})$, a body recovered quickly, without any apparent symptoms of the disease. Under average exposure to aluminum $(0.01 \mathrm{mg} / \mathrm{l})$ and the same initial conditions, dynamics of changes in flu viruses quantities corresponded to a typical average clinical course of the disease. But if influence exerted by an external factor was high $(1 \mathrm{mg} / \mathrm{l})$, viruses swiftly reproduced themselves and it resulted in almost fatal damage to a target organ. There are the following gradations for damages to a target organ tissue corresponding to a clinical form of a disease: damage to less than $8-10 \%$ of a tissue corresponds to a mild disease; $10-20 \%$, an average disease; $20-25 \%$, a grave disease; when more than $25-30 \%$ of a target organ tissue is damaged, lethal outcome is rather probable [39].

Conclusions. So, we developed a predictive mathematical model that describes functioning of the regulatory systems under exposure to a virus infection; this model allows to take into account influence exerted by exposure to chemical factors on key components in the immunity. We suggested an algorithm for conducting an experiment on identifying some parameters of influence exerted by chemical factors on interaction between the neuroendocrine and immune systems.

We examined immune regulation peculiarities via experimental research and its results revealed that there were interrelations in the system of immune evolution-controlling proteins under combined exposure to hydrocortisone (a neuroendocrine factor) and aluminum (a chemical factor). The developed mathematical model showed that detected regularities related to influences exerted by chemical and physiological factors of various genesis on functions performed by immune cells were nonlinear. These detected relationships can be applied to efficiently predict disorders in an immune response and to assess interactions between the neuroendocrine and immune systems as such interactions determine adaptation reserves of a body under technogenic exposure.

Funding. The research was not granted any sponsor support.

Conflict of interests. The authors state there is no any conflict of interests.

\section{References}

1. Heijnen C.J. Receptor regulation in neuroendocrine-immune communication: current knowledge and future perspectives. Brain, behavior, and immunity, 2007, vol. 21, no. 1, pp. 1-8.

2. Pace T.W., Negi L.T., Adame D.D., Cole S.P., Sivilli T.I., Brown T.D., Issa M.J., Raison C.L. Effect of compassion meditation on neuroendocrine, innate immune and behavioral responses to psychosocial stress. Psychoneuroendocrinology, 2009, no. 34, pp. 87-98.

3. Ashley N.T., Demas G.E. Neuroendocrine-immune circuits, phenotypes, and interactions. Hormones and Behavior, 2017, vol. 87, pp. 25-34.

4. Suarez E.C., Sundy J.S., Erkanli A. Depressogenic vulnerability and gender-specific patterns of neuro-immune dysregulation: What the ratio of cortisol to C-reactive protein can tell us about loss of normal regulatory control. Brain, Behavior, and Immunity, 2015, no. 44, pp. 137-147.

5. Lanin D.V., Zaitseva N.V., Dolgikh O.V. Neiroendokrinnye mekhanizmy regulyatsii funktsii immunnoi sistemy [Neuroendocrine Mechanisms for Regulation of Immune System]. Uspekhi sovremennoi biologii, 2011, no. 2, pp. 122-134 (in Russian).

6. Bellavance M., Rivest S. The neuroendocrine control of the innate immune system in health and brain diseases. Immunological Reviews, 2012, vol. 248, no. 1, pp. 36-55.

7. Miyake S. Mind over cytokines: Crosstalk and regulation between the neuroendocrine and immune systems. Clinical and Experimental Neuroimmunology, 2012, vol. 3, no. 1, pp. 1-15.

8. Poletaev A.B., Morozov S.G., Kovalev I.E. Regulyatornaya metasistema (immunoneiroendokrinnaya regulyatsiya gomeostaza) [Regulatory Metasystem (Immunoneuroendocrine regulation of Homeostasis)]. Moscow, Meditsina Publ., 2002, 166 p. (in Russian).

9. Chapman C.R., Tuckett R.P., Song C.W. Pain and Stress in a Systems Perspective: Reciprocal Neural, Endocrine, and Immune Interactions. Journal of Pain, 2008, vol. 9, no. 2, pp. 122-145. 
10. Savilov E.D., Mal'tsev M.V. Epidemiologicheskaya kharakteristika virusnogo gepatita S v usloviyakh krupnogo promyshlennogo goroda. Zhurnal mikrobiologii, epidemiologii i immunobiologii, 2007, no. 1, pp. 70-71 (in Russian).

11. Stepanenko L.A., Il'ina S.V., Savilov E.D. Osobennosti sostoyaniya spetsificheskogo immuniteta $\mathrm{k}$ upravlyaemym infektsiyam $\mathrm{u}$ detei (na primere kori i poliomielita) $\mathrm{v}$ usloviyakh vozdeistviya tekhnogennoi nagruzki [Features of a condition of specific immunity to controlled infections at children (on an example of measles and poliomyelitis) in conditions of technogenic influence of loading]. Byulleten' Vostochno-Sibirskogo nauchnogo tsentra Sibirskogo otdeleniya Rossiiskoi akademii meditsinskikh nauk, 2007, no. S3, pp. 66-68 (in Russian).

12. Stepanenko L.A., Savchenkov M.F., Il'ina S.V., Anganova E.V., Savilov E.D. Otsenka sostoyaniya immunnoi sistemy detskogo naseleniya kak markera tekhnogennogo zagryazneniya okruzhayushchei sredy [An assessment of the immune status of the children population as a marker of technogenic pollution of the environment]. Gigiena i sanitariya, 2016, vol. 95, no. 12, pp. 1129-1133 (in Russian).

13. Lanin D.V. Analiz koregulyatsii immunnoi i neiroendokrinnoi sistem v usloviyakh vozdeistviya faktorov riska [The analysis of the co-regulation between the immune and neuroendocrine systems under exposure to risk factors]. Analiz riska zdorov'yu, 2013, no. 1, pp. 73-81 (in Russian).

14. Zaitseva N.V., Shur P.Z., Mai I.V., Kir'yanov D.A. Metodicheskie podkhody k otsenke integral'nogo riska zdorov'yu naseleniya na osnove evolyutsionnykh matematicheskikh modelei [Approaches to the assessment of integrated health risk population based on evolution of mathematical models]. Zdorov'e naseleniya i sreda obitaniya, 2011, no. 10, pp. 6-9 (in Russian).

15. Zaitseva N.V., Trusov P.V., Shur P.Z., Kir'yanov D.A., Chigvintsev V.M., Tsinker M.Yu. Metodicheskie podkhody $\mathrm{k}$ otsenke riska vozdeistviya raznorodnykh faktorov sredy obitaniya na zdorov'e naseleniya na osnove evolyutsionnykh modelei [Methodical approaches to health risk assessment of heterogeneous environmental factors based on evolutionary models]. Analiz riska zdorov'yu, 2013, no. 1, pp. 3-11 (in Russian).

16. Zaitseva N.V., Kiryanov D.A., Lanin D.V., Chigvintsev V.M. A mathematical model of the immune and neuroendocrine systems mutual regulation under the technogenic chemical factors impact. Computational and Mathematical Methods in Medicine, 2014, vol. 2014 (in Russian).

17. Zabel P., Horst H.J., Kreiker C., Schlaak M. Circadian rhythm of interleukin-1 production of monocytes and the influence of endogenous and exogenous glucocorticoids in man. Klinische Wochenschrift, 1990, vol. 68, no. 24, pp. 1217-1221.

18. Kerdiles Y., Ugolini S., Vivier E. T cell regulation of natural killer cells. The Journal of Experimental Medicine, 2013, vol. 210, no. 6, pp. 1065-1068.

19. Andrew M.E., Churilla A.M., Malek T.R., Braciale V.L., Braciale T.J. Activation of virus specific CTL clones: antigen-dependent regulation of interleukin 2 receptor expression. The Journal of Immunology, 1985, vol. 2, no. 134, pp. 920-925.

20. Muraguchi A., Kehrl J.H., Longo D.L., Volkman D.J., Smith K.A., Fauci A.S. Interleukin 2 receptors on human B cells. Implications for the role of interleukin 2 in human B cell function. The Journal of experimental medicine, 1985, vol. 161, no. 1, pp. 181-97.

21. Demas G.E., Adamo S.A., French S.S. Neuroendocrine-immune crosstalk in vertebrates and invertebrates: Implications for host defence. Functional Ecology, 2011, vol. 25, no. 1, pp. 29-39.

22. Haus E., Smolensky M.H. Biologic rhythms in the immune system. Chronobiology international, 1999, vol. 16, no. 5, pp. 581-622.

23. Marchuk G.I., Petrov R.V., Romanyukha A.A., Bocharov G.A. Mathematical model of antiviral immune response. I. Data analysis, generalized picture construction and parameters evaluation for hepatitis B. Journal of Theoretical Biology, 1991, vol. 151, no. 1, pp. 1-40.

24. Bocharov G.A., Romanyukha A.A. Mathematical model of antiviral immune response III. Influenza A virus infection. Journal of Theoretical Biology, 1994, vol. 167, no. 4, pp. 323-360.

25. Joklik W.K., B.N. Fields, eds. Interferons. New York: Raven Press Publ., 1985, pp. 281-307.

26. Tamura S.I., Iwasaki T., Thompson A.H., Asanuma H., Chen Z., Suzuki Y., Aizawa C., Kurata T. Antibody-forming cells in the nasal-associated lymphoid tissue during primary influenza virus infection. Journal of General Virology, 1998, vol. 79, no. 2, pp. 291-299. 
27. Keenan K.P., Combs J.W., McDowell E.M. Regeneration of hamster tracheal epithelium after mechanical injury. Virchows Archiv B Cell Pathology Including Molecular Pathology, 1983, vol. 42, no. 1, pp. 231-252.

28. G.A. Bocharov, A.A. Romanyukha. Mathematical model of antiviral immune response III. Influenza A virus infection. Journal of Theoretical Biology, 1994, vol. 167, no. 4, pp. 323-360.

29. Zhdanov V.M., Bukrinskaya A.G. Reproduktsiya miksovirusov (virusov grippa i skhodnykh s nimi). Moscow, Medicina Publ., 1969, 280 p. (in Russian).

30. Bergeron Y., Ouellet N., Deslauriers A., Simard M., Olivier M., Bergeron M. Cytokine kinetics and other host factors in response to pneumococcal pulmonary infection in mice. Infection and Immunity, 1998, vol. 66, no. 3, pp. 912-922.

31. Gloff C., Wills R., B. Ferraiolo, eds. Pharmacokinetics and Metabolism of Therapeutic Cytokines. Plenum Press Publ., New York, 1992, pp. 127-150.

32. Felig P., Frohman L., eds. Endocrinology and metabolism. New York, McGraw-Hill Publ., 2001, $1562 \mathrm{p}$.

33. B.J. Carroll, F. Cassidy, D. Naftolowitz [et al.]. Veldhuis Pathophysiology of hypercortisolism in depression. Acta Psychiatrica Scandinavica, 2007, vol. 115, pp. 90-103.

34. Vinther F., Andersen M., Ottesen J.T. The minimal model of the hypothalamic-pituitary-adrenal axis. Journal of Mathematical Biology, 2011, vol. 63, no. 4, pp. 663-690.

35. Brand J.M., Schmucker P., Breidthardt T., Kirchner H. Upregulation of IFN- $\gamma$ and Soluble Interleukin-2 Receptor Release and Altered Serum Cortisol and Prolactin Concentration during General Anesthesia. Journal of Interferon \& Cytokine Research, 2001, vol. 10, no. 21, pp. 793-796. DOI: $10.1089 / 107999001753238024$

36. Yoneda K., Osaki T., Yamamoto T., Ueta E. Effects of tumour necrosis factor-alpha (TNF-alpha), IL-1 beta and monocytes on lymphokine-activated killer (LAK) induction from natural killer (NK) cells and T lymphocytes. Clinical \& Experimental Immunology, 1993, vol. 2, no. 93, pp. 229-236.

37. Callewaert D.M., Moudgil V.K., Radcliff G., Waite R. Hormone specific regulation of natural killer cells by cortisol. Direct inactivation of the cytotoxic function of cloned human NK cells without an effect on cellular proliferation. FEBS Letters, 1991, vol. 1, no. 285, pp. 108-110.

38. Marchuk G.I., Berbentsova E.P. Ostrye pnevmonii. Immunologiya, otsenka tyazhesti, klinika, lechenie. Moscow, Nauka Publ., 1989, 304 p. (in Russian).

39. Callewaert D.M., Moudgil V.K., Radcliff G., Waite R. Hormone specific regulation of natural killer cells by cortisol. Direct inactivation of the cytotoxic function of cloned human NK cells without an effect on cellular proliferation // FEBS Lett, 1991, vol. 285, no. 1, pp. 108-110.

40. Wohlfartt C. Neutralization of Adenoviruses: Kinetics, Stoichiometry, and Mechanisms // J. Immunol. 1988, vol. 62, no. 7, pp. 2321-2328.

Trusov P.V., Zaitseva N.V., Chigvintsev V.M. Assessing risks of adverse clinical course and outcome of an infectious disease with mathematical modeling of exposure to environmental factors on the example of aluminum oxide. Health Risk Analysis, 2019, no. 1, pp. 17-29. DOI: 10.21668/health.risk/2019.1.02.eng

Received: 01.02.2019

Accepted: 28.02 .2019

Published: 30.03.2019 
UDC 613.95: 616-006.44: 614.876

DOI: $10.21668 /$ health.risk/2019.1.03.eng

\title{
THE RISK OF ONCOHEMATOLOGICAL PATHOLOGY IN CHILDREN OF WORKERS EMPLOYED AT RADIATION HAZARDOUS PRODUCTION
}

\author{
S.F. Sosnina, N.R. Kabirova, M.E. Sokolnikov, P.V. Okatenko \\ The Southern Urals Biophysics Institute of the RF Federal Medical and Biological Agency, \\ 19 Ozerskoe drive, Ozersk, 456780, Russian Federation
}

Preconceptive irradiation is considered to be a potential risk factor that can cause hemolymphoblastosis in children conceived and borne by irradiated parents. A population cohort that comprises workers employed at "Mayak" Production Association (Mayak PA), the first nuclear cycle enterprise, is a unique sampling to calculate a carcinogenic risk in their children.

Our research goal was to assess risk of hemolymphoblastosis among children conceived and borne by workers employed at Mayak PA with individual preconceptive accumulated absorbed dozes.

Data and methods. We performed retrospective research as per "case-control" study among all the people living in the city of Ozersk located near Mayak PA. Hemolymphoblastosis diagnosed in people younger than 25 in 1949-2009 (81 people) were considered to be "cases"; "controls were chosen taking into account sex, birth date, and parents' age when a child was borne (324 people). We calculated odds ratio and excessive relative risk per external gamma-radiation dose unit (ERR/Gy) with $95 \%$ confidence interval; to do that, we applied PEGAN program module of EPICURE software.

Results. Acute leukemia prevailed in the structure of hemolymphoblastosis, acute lymphatic leukemia occupying the first place. We didn't reveal any statistic correlation between a factor related to parents' preconceptive irradiation and oncohematologic pathologies in their offspring: overall, odds relation was equal to $0.76(0.46-1.26)$. As we analyzed "dose - effect" correlation, we didn't reveal any statistically significant increase in morbidity with hemolymphoblastosis depending on a dose of irradiation accumulated by their parents. ERR/Gy quotients were insignificant both for a dose accumulated by a mother and that accumulated by a father. Non-parametric analysis taking into account dose categories didn't reveal any elevated risks either.

Conclusion. We didn't detect any dose dependence between long-term preconceptive external gamma-irradiation accumulated by parents and risks of hemolymphoblastosis in their children. However, a relatively insignificant number of hemolymphoblastosis cases among children younger than 25 imposes certain limitations on validity of our conclusions. Susceptibility to neoplasms in children and manifestation of the effect as a solid carcinoma at older ages are rather probable and it means that further observation and research is required.

Key words: preconceptive radiation exposure of workers, children, dose dependence, risk assessment, malignant neoplasms in lymphoid and blood-making tissues.

Multiple experimental research considers preconception irradiation as a risk factor that can cause genetic instability, changes in DNA polymorphism $[1,2]$, and offspring susceptibility to neoplastic processes [3-5]. Several works dwell on cytogenetic effects as oncologic diseases predictors and on their probable trans-generational transfer among irradiated people [6-9]. But still, epidemiologic assessment of effects produced by preconception irradiation is rather controversial, and there are no common conclusions on peculiarities and regularities which carcinogenic processes have in offspring of people who were exposed to ionizing irradiation $[10,11]$.

Malignant neoplasms (MN) in lymphoid and blood-making tissues are the most widely spread oncologic pathology among children $[12,13]$. A lot of researchers have had great interest in a probable cause-and-effect relationship between parents being exposed to preconception irradiation and hemolymphoblastosis in their children. In 90ties last century several works were published; they focused on testing a so called "Gardner hypothesis" [14] that stated the following: irradiation received by fathers be-

(C) Sosnina S.F., Kabirova N.R., Sokolnikov M.E., Okatenko P.V., 2019

Svetlana F. Sosnina - Candidate of Medicine, Researcher at Radiation Epidemiology Laboratory (e-mail: sosnina@subi.su; tel: +7 (351) 307-66-27; ORCID: https://orcid.org/0000-0003-1553-0963).

Nailya R. Kabirova - Assistance Manager to the Head of Radiation Epidemiology Laboratory (e-mail: kabirova@subi.su; tel: +7 (351) 307-30-76; ORCID: https://orcid.org/0000-0001-7724-6103).

Mikhail E. Sokolnikov - Doctor of Medicine, Head of Epidemiology Department (e-mail: sokolnikov@subi.su; tel: +7 (351) 307-16-52; ORCID: https://orcid.org/0000-0001-9492-4316).

Pavel V. Okatenko - Head of the Group on Computational Hardware and Software, Radiation Epidemiology Laboratory (e-mail: okatenko@subi.su; tel: +7 (351) 307-69-03; ORCID: https://orcid.org/0000-0002-8260-1808). 
fore conception could cause leukemia and nonHodgkin's lymphoma in their children. A correlation between parents' preconception irradiation and leucosis in their children wasn't confirmed in most of them $[15,16]$ or evidences weren't convincing enough due to an insignificant number of oncohematological cases [17, 18]. Controversial results obtained in assessing effects produced by parents' irradiation and related risks of neoplastic processes in their children are still inducing scientific disputes [11, 19-21].

"Mayak" production association (Mayak PA) is the first enterprise in the country that dealt with nuclear production; it was put into operation in 1948. This association includes radiochemical, reactor, and plutonium production as well as several auxiliary divisions. During several first years of Mayak PA operations its personnel might have been exposed to long-term external gamma-irradiation and internal alphairradiation by incorporated plutonium-239 in significant doses; and we should note that a quarter of all workers employed at Mayak PA back then were women in their reproductive age. Given that, a cohort made up of workers employed at Mayak PA is one of the most representative groups in the world to assess effects produced by parents' irradiation, including analysis of oncohematological pathology in their children.

Our research goal was to assess risks of $\mathrm{MN}$ in lymphoid and blood-making tissues among children born by personnel employed at Mayak PA applying total absorbed individual preconception doses.

Data and methods. We conducted a retrospective examination based on registers created and supported in the Laboratory for Radiation Epidemiology at the Southern Urals Biophysics Institute:

- Register with entries on personnel employed at Mayak PA in 1948-2015 including 36,036 people who worked at the main and auxiliary plants of the enterprise; this register provided data on parents' occupational histories;

- Cancer Register that contains data on more than 15,000 cancer cases which have been diagnosed since 1948 among people living in Ozersk, a closed town located near Mayak PA;

- Children Register that contains data on 90,835 people who were born in 1934-2009 in
Ozersk or came to this town in their childhood and spent not less than 1 year in it.

We applied a "case - control study in a cohort" where a "case" was a patient younger than 25 who was suffering from hemolymphoblastosis and a "control" was a person of the same age without such a diagnosis. "Cases" group included all patients with hemolymphoblastosis registered in Ozersk from 1949 to 2009 who were younger than 25 (81 children overall, 49 boys and 32 girls). "Control" group was made up with a comparable pair method as we selected four controls from Children Register for each child with hemolymphoblastosis so that they matched in sex, birth year, and age of parents at the moment of childbirth. Groups were formed among all the children population in Ozersk and it allowed to level off other probable disturbing factors, for example, possible technogenic impacts exerted on people living in the town by its close proximity to Mayak PA. All the selected children were provided with medical services of the same quality and quite similar nutrition in children facilities located in the closed town. As a result, "Control" group consisted of 324 children without any oncologic diseases (196 boys and 128 girls).

Having formed the groups, we detected whether parents had been exposed to preconception irradiation and if yes than what doses they had been exposed to; to do that, we took data from the Mayak PA Personnel Register, registers with data on people who might have been irradiated, for example, liquidators of the emergency that happened at the enterprise in 1957, Chernobyl liquidators, people who had lived on the Eastern Urals radioactive track territory, people employed at construction organizations or military personnel who might have been exposed to radiation before their children were conceived. Data on individual doses of external gamma-irradiation accumulated by personnel employed at Mayak PA were provided by the Radiation Safety Service of the enterprise from the "Mayak PA Personnel Dosimetric System2008" [22, 23].

The structure of $\mathrm{MN}$ in lymphoid and blood-making tissues is given according to the ICD-9 and ICD-10 that were valid during the examined period $[24,25]$. 
We applied the following statistical analysis techniques in our research:

- frequencies comparison with $\chi^{2}$ criterion and Fisher's exact test, discrepancies were considered to be authentic at $\mathrm{p}<0.05$;

- odds ratio (OR) calculation with $95 \%$ confidence interval $(\mathrm{CI})$;

- calculation of excess relative risk (ERR) per a unit of external gamma-irradiation dose with $95 \%$ confidence interval; it was performed in PECAN software module of EPICURE software package [26]. Data in a table that showed person-years were distributed as per sex, birth date, $\mathrm{MN}$ nosology, and a date when a $\mathrm{MN}$ was diagnosed. We took into account total preconception doses of external gamma-irradiation received by mothers and fathers on an overall body and separately on the gonads. Individual doses were divided into $250 \mathrm{mGy}$ intervals and an average dose was calculated for each interval. Morbidity with hemolymphoblastosis among children that was detected without any exposure to radiation was considered to be a background level taking into account discrepancies related to an age at which a MN was diagnosed, sex, or age. P-test values for statistical significance were calculated with maximum likelihood techniques, and discrepancies were considered to be statistically significant at $\mathrm{p}<0.05$.

Groups characteristics taking into account preconception irradiation parents had been exposed to at their workplaces is given in Table 1 .

Each group was divided into two subgroups: children born by parents who had accumulated preconception irradiation doses and children born by parents who had never been exposed to any occupational irradiation before they conceived a child. A share of children born by irradiated parents was lower in "Cases" group than among children without hemolymphoblastosis as $35.8 \%$ (29 children) in "cases" group were born in families where parents had accumulated preconception irradiation doses; as for the group that included children without any on- cohematological pathology, 42.3\% (137 children) were born by parents who had been exposed to occupational irradiation before conception.

Workers who had contacted ionizing radiation sources at their workplaces before conception might have been exposed to combined irradiation (external gamma- and internal alpha-irradiation). Most parents in the compared groups were employed at radiochemical and reactor productions of Mayak PA. We didn't analyze any relationship between $\mathrm{MN}$ in lymphoid and blood-making tissues in children and parents' doses of internal irradiation by incorporated plutonium-239 due to a rather insignificant number of people who had undergone monitoring of internal alpha-irradiation accumulated in their bodies.

Results and discussion. Over 60-yearlong examination period (1949-2009) $\mathrm{MN}$ in lymphoid and blood-making tissues were diagnosed in 81 children, and more frequently in boys ( 49 people or $60.5 \%$ ). Prevalence of males among patients with hemolymphoblastosis (sex ratio is $1.53: 1$ ) is in line with regional, national, and world statistics [13, 27, 28]. The highest number of oncohematological pathology among children were registered in time periods from 1980 to 1989 and from 1990 to 1999 (18 and 19 cases respectively). Average age at which hemoblastosis occurred among boys was equal to 11.5; among girls, 9.5. The structure of $\mathrm{MN}$ in lymphoid and blood-making tissues among overall children population living in Ozersk over 60 years is given on Figure 1.

Acute leukemia prevailed among all the $\mathrm{MN}$ in lymphoid and blood-making tissues with 45 cases $(55.6 \%)$ of which 23 cases or $51.1 \%$ belonged to acute lympholeucosis and it corresponds to literature data [13, 27, 28]. Myeloid leukemia accounted for $26.7 \%$ (12 cases) among all acute leukemia cases. Monocytic leukemia was registered only once, in a 5-year old boy born by a father who had been employed at reactor production and exposed to

Table 1

Group characteristics

\begin{tabular}{|c|c|c|c|c|c|c|c|c|c|}
\hline \multirow{2}{*}{ Group } & \multicolumn{3}{|c|}{ Number of children in a group } & \multicolumn{3}{|c|}{ Born by irradiated parents } & \multicolumn{3}{|c|}{ Born by non-exposed parents } \\
\hline & Total & Boys & Girls & Total & Boys & Girls & Total & Boys & Girls \\
\hline "Cases" & 81 & 49 & 32 & 29 & 19 & 10 & 52 & 30 & 22 \\
\hline "Controls" & 324 & 196 & 128 & 137 & 86 & 51 & 187 & 110 & 77 \\
\hline
\end{tabular}




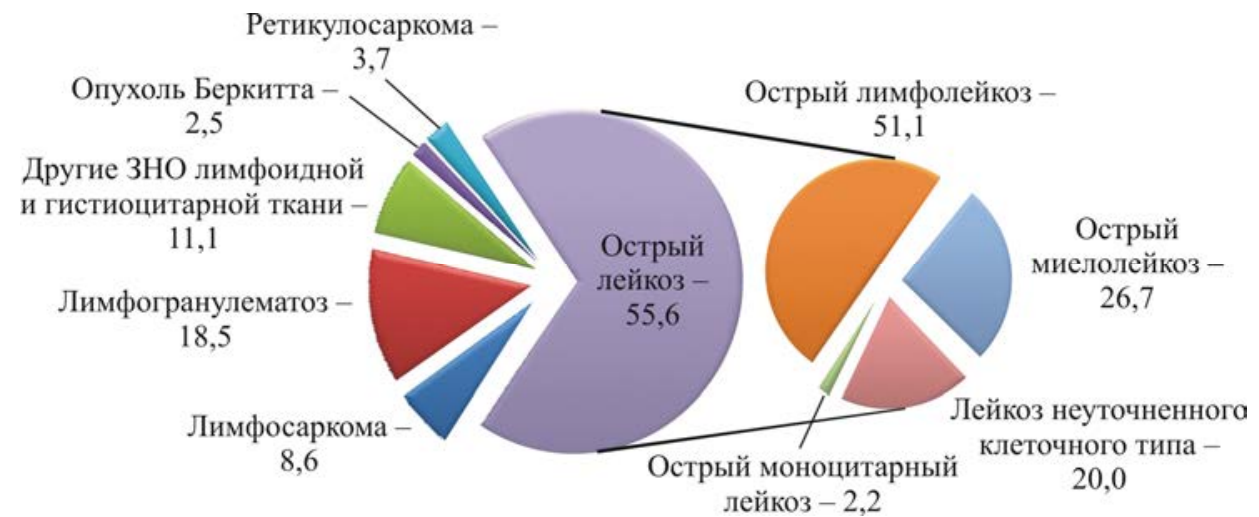

Figure1. Hemolymphoblastosis among children in Ozersk.

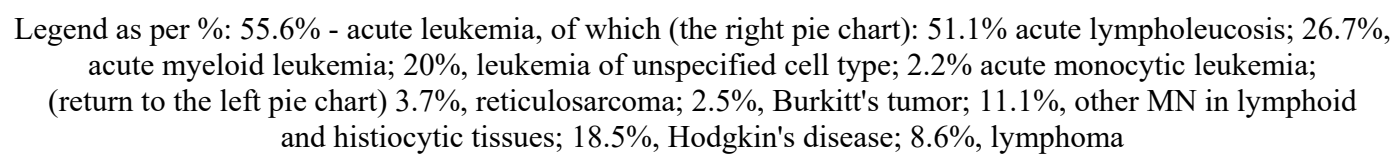

total preconception external gamma-irradiation on his gonads in a dose equal to $210 \mathrm{mGy}$.

Acute leukemia of unspecified cell type was detected in 9 children and it accounted for one fifth of all leukemia cases in children. Most of these unspecified leukemias were diagnosed in 1960-1980; back then it was next to impossible to identify an acute leukemia subtype due to absence of histochemical, immunological, and cytogenetic research techniques.

The second place among all hemolymphoblastosis belongs to Hodgkin's disease (18.5\% or 15 cases). Average age at which the disease became apparent amounted to 16.2, without any gender discrepancies. Two Burkitt's tumors were registered among diffused nonHodgkin's lymphomas, in a 8-year-old girl and 21-year-old boy, both born by parents who hadn't been exposed to any preconception irradiation. "Other malignant neoplasms in lymphoid and histiocytic tissues" category included histiocytic lymphomas and malignant histiocytosis; these diseases accounted for $11.1 \%$ (9 cases) of all hemolymphoblastosis among children living in the closed town.

Structure of hemolymphoblastosis among children born by parents exposed to occupational preconception irradiation is very similar to that described above. Acute leukemia prevailed $(62.1 \%$ or 18 cases $)$; lymphoblastic leukemia took the first place among acute leukemias $(44.4 \%$ or 8 cases); myeloid leukemia accounted for one third of all leukemia cases in children (33.3\% or 6 cases); a single monocytic leukemia case was diagnosed. A contribution made by leukemia of unspecified cell type was a bit different and accounted for $16.7 \%$ ( 3 cases) of all leukemia cases. A share that belonged to Hodgkin's disease among all $\mathrm{MN}$ in lymphoid and blood-making tissues was statistically insignificantly higher among children borne by parents who had been exposed to occupational preconception irradiation than among children whose parents hadn't been exposed to it (20.7\% against $17.3 \%, \mathrm{p}>0.05)$.

We should note that specific contribution made by all neoplasms in lymphoid tissues among children of irradiated parents didn't have any discrepancies from that among children whose parents were intact $(37.9 \%$ against $48.1 \%, \mathrm{p}>0.05)$. We compared contributions made by lymphoid leukemia and myeloid leukemia into oncohematological pathology structure among children born by exposed and nonexposed parents and didn't reveal any statistically significant discrepancies.

We didn't detect any gender differences in the structure of MN in lymphoid and bloodmaking tissues among children born by irradiated parents. Average age at which $\mathrm{MN}$ occurred among children born by exposed parents amounted to 14 years among boys and 8.2 years among girls.

Overall, we didn't detect any significant differences in the structure of child hemolymphoblastosis between national and world sta- 
tistical data and either children born by workers employed at nuclear production or total children population of Ozersk [13, 28].

Total doses of preconception external gamma-irradiation absorbed by parents at their workplaces varied significantly. Table 2 contains data on accumulated preconception irradiation doses.

Average total doses of preconception external gamma-irradiation absorbed by parents were higher in "Controls" group (children without oncologic pathology) than among exposed parents whose children were included into "Cases" group. However, maximum preconception dose of external gamma-irradiation on an overall body was detected among fathers of children with oncohematological pathologies and reached 3,397.3 mGy while a maximum dose among mothers amounted to 2,797.8 mGy and was detected in "Controls" group.

Average absorbed doses of preconception external gamma-irradiation on the gonads were higher among parents in "Controls" group than among parents in "Cases" group. Irradiation on the gonads varied within a substantial range, the highest accumulated dose being about 3 Gy; it was registered in parents from both groups as the maximum external gamma-irradiation dose on the gonads amounted to $3,121.8 \mathrm{mGy}$ in "Cases" group, and to 2,899.3 mGy, in "Controls" group.

Average preconception doses of external gamma-irradiation on the gonads were in some cases higher than doses on an overall body; on one hand, it can be due to uneven irradiation of Mayak PA personnel; on the other hand, quantity of individual doses on the gonads among workers was relatively insignificant, therefore, average values could be shifted.

Figure 2 shows how workers employed at Mayak PA are distributed as per accumulated preconception doses of external gamma-irradiation on an overall body.

Table 2

Preconception external gamma-irradiation accumulated by parents

\begin{tabular}{|l|c|c|c|c|}
\hline \multirow{2}{*}{$\begin{array}{c}\text { External gamma- } \\
\text { irradiation doses, mGy }\end{array}$} & \multicolumn{2}{c|}{ Exposed parents in "Cases" group } & Exposed parents in "Controls" group \\
\cline { 2 - 5 } & Fathers & Mothers & Fathers & Mothers \\
\hline \multicolumn{5}{|c|}{ External gamma-irradiation doses on an overall body } \\
\hline Average dose & $257.4 \pm 122.9^{*}$ & $244.3 \pm 206.1$ & $335.3 \pm 52.4$ & $458.1 \pm 129.6$ \\
\hline \multirow{2}{*}{ Median doses } & 50.1 & 42.1 & 62.9 & 125.5 \\
& $(19.5-177.6)^{* *}$ & $(20.7-84.8)$ & $(25.0-325)$ & $(24.9-731.2)$ \\
\hline Doses range & $2.7-3397.3$ & $2.06-1272.9$ & $0.3-3025.6$ & $2.13-2797.8$ \\
\hline \multicolumn{5}{|c|}{ External gamma-irradiation doses on gonads } \\
\hline Average dose & $338.5 \pm 188.3$ & $275.2 \pm 241.8$ & $411.6 \pm 70.4$ & $452.9 \pm 123.2$ \\
\hline \multirow{2}{*}{ Median doses } & 70.1 & 49.5 & 111.2 & 127.7 \\
\hline Doses range & $(37.9-210.2)$ & $(20.5-529.9)$ & $(31.2-337.7)$ & $(57.6-597.5)$ \\
\hline
\end{tabular}

* is standard deviation, ${ }^{* *}$ means an inter-quartile distance is given in brackets.

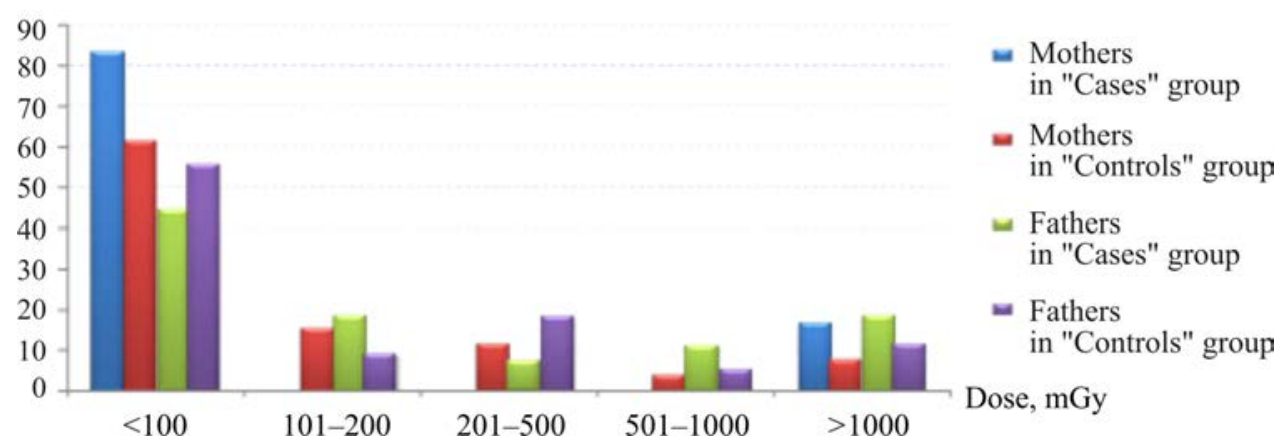

Figure 2. Distribution of Mayak PA workers as per total preconception doses of external gamma-irradiation on an overall body (\%) 
An accumulated dose didn't exceed 100 mGy among most irradiated parents. Preconception irradiation among mothers in "Cases" group had two end intervals, from 2.06 to 100 mGy and higher than 1,000 mGy. Mothers from "Controls" group were present in all dose categories. The smallest number of fathers in "Cases" group were exposed to preconception irradiation in a dose within 201-500 mGy range, while the minimal number of fathers in "Controls" group was detected in a dose category from 501 to $1,000 \mathrm{mGy}$. Total preconception doses of external gamma-irradiation on the gonads among Mayak PA workers were distributed in a similar way.

Most MN in lymphoid and blood-making tissues among children born by exposed parents were detected within a below $500 \mathrm{mGy}$ range of total preconception external gammairradiation doses received by parents on an overall body ( $79.3 \%$ or 23 cases). Acute leukemia was diagnosed among children born by parents exposed to a dose within 2.06-3,397.3 mGy range with an average dose on an overall body being equal to $312.8 \pm 170.8 \mathrm{mGy}$; on the gonads, $391.5 \pm 261.1 \mathrm{mGy}$. MN in lymphoid tissue were detected within 2.7-1,005.3 mGy doses range with an average external gamma-irradiation dose on an overall body being equal to $170.4 \pm 78.4 \mathrm{mGy}$; on the gonads, $233.7 \pm 105.5 \mathrm{mGy}$.
In order to reveal any statistical correlation between a risk factor (parents exposed to occupational preconception irradiation) and an outcome (hemolymphoblastosis in their children), we calculated odds ratio; the results are shown in Table 3.

OR in groups on general was equal to $0.76(0.46-1.26)$ and it proved there was no statistically significant correlation between parents being irradiated and oncohematological pathology in their children. OR amounted to $0.81(0.43-1.54)$ among boys, and to 0.69 (0.3-1.57) among girls, and it was also an evidence that there was no correlation between the examined risk factor (parents exposed to preconception irradiation) and a possible outcome in their children (hemolymphoblastosis).

To reveal whether carcinogenic risks in offspring were dose-dependent, we performed "dose - effect" analysis together with calculating excess relative risk of hemolymphoblastosis. The analysis covered total preconception irradiation doses received by parents on an overall body and separately on the gonads. The results are given in Table 4.

We applied a linear model to estimate ERR and didn't reveal any statistically significant increase in morbidity with hemolymphoblastosis depending on an irradiation dose received by parents. ERR/Gy quotients were insignificant in both cases among mothers

Table 3

Odds ratio calculation

\begin{tabular}{|l|c|c|c|c|c|c||c|c|c|}
\hline \multirow{2}{*}{ Group } & \multicolumn{3}{|c|}{ Risk factor occurs } & \multicolumn{2}{c|}{ Risk factor doesn't occur } & \multicolumn{3}{c|}{ OR (95\% CI) } \\
\cline { 2 - 9 } & Total & Boys & Girls & Total & Boys & Girls & Total & Boys & Girls \\
\hline $\begin{array}{l}\text { There is an } \\
\text { outcome (n=81) }\end{array}$ & 29 & 19 & 10 & 52 & 30 & 22 & $\begin{array}{c}0.76 \\
(0.46-1.26)\end{array}$ & $\begin{array}{c}0.81 \\
(0.43-1.54)\end{array}$ & $\begin{array}{c}0.69 \\
(0.3-1.57)\end{array}$ \\
\hline $\begin{array}{l}\text { There is no } \\
\text { outcome (n=324) }\end{array}$ & 137 & 86 & 51 & 187 & 110 & 77 & \\
\hline
\end{tabular}

Table 4

Excess relative risk (ERR) of hemoblastosis depending on preconception doses accumulated by parents

\begin{tabular}{|l|c|c|c|}
\hline \multicolumn{1}{|c|}{$\begin{array}{c}\text { Total preconception doses of external } \\
\text { gamma-irradiation accumulated by parents }\end{array}$} & ERR/Gy & $95 \%$ confidence interval & $p$ \\
\hline Fathers' doses on an overall body & -0.4015 & {$[-0.97 ; 0.14]$} & $>0.05$ \\
\hline Mothers' doses on an overall body & -0.0036 & {$[-1.08 ; 0.93]$} & $>0.05$ \\
\hline Fathers' doses on the gonads & -0.3148 & {$[-0.93 ; 0.26]$} & $>0.05$ \\
\hline Mothers' doses on the gonads & -0.2235 & {$[-1.57 ; 0.89]$} & $>0.05$ \\
\hline
\end{tabular}


and fathers employed at Mayak PA, either with an accumulated external gamma-irradiation dose on an overall body or separately on the gonads.

A.N. Koterov is being involved in a discussion on the genome instability being induced under small radiation doses and more frequent mutagenesis and carcinogenesis caused by them; he considers [29] different points of view expressed by several authors and notes results obtained via some experimental research when no instability in the genome was observed under exposure to doses smaller than 0.1-0.2 Gy but probable threshold for its induction amounted to 0.5 Gy with low linear energy transfer.

Analysis of our data taking into account dose categories with preconception doses intervals being equal to $250 \mathrm{mGy}$ didn't reveal any increase in carcinogenic risks as statistically insignificant negative ERR/Gy values were observed in the groups. At certain points, ERR value for hemolymphoblastosis associated with an external gamma-irradiation doses on the gonads was uncertain due to few available statistical data.

Therefore, our analysis didn't confirm an assumption that increased risks of $\mathrm{MN}$ in lymphoid and blood-making tissues could be somehow related to parents' exposure to preconception gamma-irradiation.

When accomplishing our research, we took into account impacts exerted by such nonradiation factors as sex, birth date, age of parents at the moment a child was born, and age at which $\mathrm{MN}$ was diagnosed. We should note that multiple factors have been described up to now that can cause oncogenic processes in lymphoid and blood-making tissues. Experts consider several factors that cause child hemolymphoblastosis, for example, infectious agents [30], preconception contact with chemical carcinogens [31], compromised obstetric history and $\mathrm{MN}$ occurrence in close relatives [27], deviations in perinatal period and anthropometric status peculiarities at birth [32], pre- and post-natal exposure to electromagnetic fields [33], and many other nonradiation factors that can't always be analyzed quantitatively [34]. Our task in the present research was to reveal a statistical correlation between a single probable risk factor, parents' occupational preconception irradiation, and neo- plastic hematologic processes in their offspring. Therefore, we didn't make any changes in our model in order to modify a dose response with various non-radiation factors.

The results we obtained are well in line with research $[35,36]$ that didn't reveal any statistically significant impacts via analyzing long-term effects produced by exposure to ionizing radiation.

Probably, estimation of a dose effect in our research was influenced by an initially insignificant statistical base as malignant neoplasms were relatively rare in children. But when an observation age for a cohort of children born by irradiated parents was increased up to 25 years [37], it didn't change any ultimate results in comparison with our previous research.

It is also important to note that parents who were exposed to preconception irradiation were employed at a nuclear production; workers were thoroughly selected to get a job there, including medical examinations, as they all should have very good health. Given that, irradiated parents could initially have greater health than parents from "Controls" group. Moreover, a rather small number of exposed parents in our sampling doesn't allow to be sure that there is no correlation between long-term exposure to ionizing irradiation before conception and malignant neoplasms occurrence in offspring.

So, we can assume that radiation-induced risk assessment depends on statistical significance of a group being examined; this, together with $\mathrm{MN}$ being a multi-factor disease, substantiates a necessity to continue research on effects produced on offspring by occupational preconception irradiation.

Conclusion. We analyzed risks of oncohematological pathology in children born by irradiated parents with "case - control in a cohort" method and individual estimates of external gamma-irradiation doses accumulated before a child was conceived. A cohort chosen for the research was made up of children born by parents employed at the first nuclear cycle enterprise in the country. We tested impacts exerted by parents' preconception irradiation on risks of hemoblastosis in their children via calculating odds ratio and assessing a dose-effect relationship. 
We included all cases of $\mathrm{MN}$ in lymphoid and blood-making tissues that occurred among children born in families of Mayak PA workers at an age up to 25 years, more than 90,000 people were observed during a 60 -year observation over children living in Ozersk; still, in spite all that, we couldn't detect any authentic increase in hemoblastosis risk among children born by parents who had been exposed to preconception irradiation at their workplaces.

We spotted out a single factor, preconception irradiation, among variable potential carcinogenic ones, and assessed it quantitatively; the assessment revealed there was no correlation between parents being exposed to irradiation and elevated MN risks in their children. Totally, OR amounted to 0.76 (0.46-1.26). ERR/Gy quotient, taking into account absorbed doses on an overall body, amounted to -0.4 [-0.97; 0.14] among fathers; -0.0036 [-1.08; 0.93], among mothers. ERR/Gy quotient, depending on an overall dose on the gonads received by fathers, amounted to $-0.31[-0.93$; $0.26]$; by mothers, -0.22 [-1.57; 0.89]. ERR analysis performed in dose categories with an interval equal to $250 \mathrm{mGy}$ didn't reveal any significant deviations from previous ERR calculations.

However, a relatively low number of $\mathrm{MN}$ in lymphoid and blood-making tissues imposes certain limitations on the validity of our conclusions; therefore, we can't state that a contact with ionizing irradiation at a workplace before conception is safe as regards carcinogenic risks for future children. Susceptibility to neoplasms in children and the effect manifestation as solid cancer at older ages can't be totally excluded and it is advisable to continue research on the subject.

Funding. The work has been accomplished with the State Contract No. 11.305.18.0 with its research subject being "Analysis of effects produced by exposure to ionizing radiation on health of personnel employed at Mayak PA and health of their children via assessing radiogenic risks".

Conflict of interests. The authors state there isn't any conflict of interests.

\section{References}

1. Bashlykova L.A. Nasledovanie tsitogeneticheskikh i molekulyarno-kletochnykh effektov v kletkakh kostnogo mozga zhivotnykh pri khronicheskom vozdeistvii ioniziruyushchego izlucheniya [Inheritance of cytogenetic and molecular cell effects in the bone marrow cells of animals with chronic exposure to ionizing radiation]. Izvestiya Samarskogo nauchnogo tsentra Rossiiskoi akademii nauk, 2017, vol. 19, no. 2-3, pp. 420-425 (in Russian).

2. Lomaeva M.G., Fomenko L.A., Vasil'eva G.V., Bezlepkin V.G. Tkanespetsificheskie izmeneniya urovnya polimorfizma prostykh povtorov v DNK potomkov raznogo pola, rozhdennykh ot obluchennykh samtsov ili samok myshei [Tissue-specific changes in the level of polymorphism of simple repeats in the DNA of descendants of different sex, born to irradiated male or female mice]. Radiatsionnaya biologiya. Radioekologiya, 2016, vol. 56, no. 2, 149 p. (in Russian).

3. Suman S., Kumar S., Moon B.H., Fornace A.J., Kallakury B., Datta K. Increased Transgenerational Intestinal Tumorigenesis in Offspring of Ionizing Radiation Exposed Parent APC1638N/+ Mice. Journal of Cancer, 2017, vol. 8, no. 10, pp. 1769-1773. DOI: 10.7150/jca.17803

4. Paris L., Giardullo P., Leonardi S., Tanno B., Meschini R., Cordelli E., Benassi B., Longobardi M.G. [et al.]. Transgenerational inheritance of enhanced susceptibility to radiation-induced medulloblastoma in newborn Ptch $1^{+} /$mice after paternal irradiation. Oncotarget, 2015, vol. 6, no. 34, pp. 36098-112. DOI: 10.18632/oncotarget.5553

5. Lord B.I., Hoyes K.P. Hemopoietic damage and induction of leukemia in offspring due to preconception paternal irradiation from incorporated plutonium-239. Radiation Research, 1999, vol. 152 (6 Suppl), pp. 34-37.

6. Suskov I.I., Kuz'mina N.S., Suskova V.S., Agadzhanyan A.V., Rubanovich A.V. Individual'nye osobennosti transgeneratsionnoi genomnoi nestabil'nosti u detei likvidatorov posledstvii avarii na ChAES (tsitogeneticheskie i immunogeneticheskie pokazateli) [Individual features of transgenerational genomic instability in children of the liquidators of the consequences of the Chernobyl accident (cytogenetic and immunogenetic indicators)]. Radiatsionnaya biologiya. Radioekologiya, 2008, vol. 48, no. 3, pp. 278-286 (in Russian).

7. Baleva L.S., Nomura T., Sipyagina A.E., Karakhan N.M., Yakusheva E.N., Egorova N.I. Tsitogeneticheskie effekty i vozmozhnosti ikh transgeneratsionnoi peredachi v pokoleniyakh lits, prozhivayushchikh 
$\mathrm{v}$ regionakh radionuklidnogo zagryazneniya posle avarii na Chernobyl'skoi AES [Cytogenetic effects and possibilities of their transgenerational transfer in the generations of persons living in radionuclide polluted areas after the Chernobyl accident]. Rossiiskii vestnik perinatologii $i$ pediatrii, 2016, vol. 3, pp. 87-94 (in Russian).

8. Rusinova G.G., Glazkova I.V., Azizova T.V., Osovets S.V., Vyazovskaya N.S. Izuchenie nestabil'nosti genoma potomkov v sem'yakh rabotnikov PO «Mayak»: minisatellit SEV 1 [Analysis of Genome Instability in Offspring of "Mayak" Workers Families: Minisatellite CEB1]. Genetika, 2014, vol. 50, no. 11, pp. 1354-1362 (in Russian).

9. Apsalikov K.N., Muldagaliev T.Zh., Belikhina T.I., Tanatova Z.A., Kenzhina L.B. Analiz i retrospektivnaya otsenka rezul'tatov tsitogeneticheskikh obsledovanii naseleniya Kazakhstana, podvergavshegosya radiatsionnomu vozdeistviyu v rezul'tate ispytanii yadernogo oruzhiya na Semipalatinskom poligone, i ikh potomkov [Analysis and retrospective assessment of the results of cytogenetic surveys of the population of Kazakhstan exposed to radiation as a result of nuclear weapon tests at the Semipalatinsk test site, and their descendants]. Mediko-biologicheskie problemy zhiznedeyatel'nosti, 2013, vol. 9, no. 1, pp. 42-49 (in Russian).

10. Sources, effects and risks of ionizing radiation: UNSCEAR Report. Effects of radiation exposure of children. UNITED NATIONS, New York. 2013, vol. II, $282 \mathrm{p}$.

11. Little M.P., Goodhead D.T., Bridges B.A., Bouffler S.D. Evidence relevant to untargeted and transgenerational effects in the offspring of irradiated parents. Mutation Research, 2013, vol. 753, no. 1, pp. 50-67. DOI: 10.1016/j.mrrev.2013.04.001

12. Puumala S.E., Ross J.A., Aplenc R., Spector L.G. Epidemiology of childhood acute myeloid leukemia. Pediatric Blood and Cancer, 2013, vol. 60, no. 5, pp. 728-733.

13. Metayer C., Milne E., Clavel J., Infante-Rivard C., Petridou E., Taylor M., Schüz J., Spector L.G. [et al.]. The Childhood Leukemia International Consortium. Cancer Epidemiology, 2013, vol. 37, no. 3, pp. 336-347.

14. Gardner M.J., Snee M.P., Hall A.J., Powell C.A., Downes S., Terrell J. D. Results of casecontrol study of leukaemia and lymphoma among young people near Sellafield nuclear plant in West Cumbria. British Medical Journal, 1990, vol. 300, pp. 423-429.

15. McLaughlin J.R., King W.D., Anderson T.W., Clarke E.A., Ashmore J.P. Paternal radiation exposure and leukaemia in offspring: the Ontario case-control study. British Medical Journal, 1993, vol. 307, no. 6910, pp. 959-966.

16. Kinlen L.J, Clarke K., Balkwill A. Paternal preconceptional radiation exposure in the nuclear industry and leukaemia and non-Hodgkin's lymphoma in young people in Scotland. British Medical Journal, 1993, vol. 306, no. 6886, pp. 1153-1158.

17. Draper G.J, Little M.P., Sorahan T., Kinlen L.J, Bunch K.J., Conquest A.J., Kendall G.M., Kneale G.W. [et al.]. Cancer in the offspring of radiation workers: a record linkage study. British Medical Journal, 1997, vol. 315, no. 7117, pp. 1181-1188.

18. Roman E., Doyle P., Maconochie N., Davies G., Smith P.G., Beral V. Cancer in children of nuclear industry employees: report on children aged under 25 years from nuclear industry family study. British Medical Journal, 1999, vol. 318, no. 7196, pp. 1443-1450.

19. Kamiya K., Ozasa K., Akiba S., Niwa O., Kodama K., Takamura N., Zaharieva E.K., Kimura Y. [et al.]. Long-term effects of radiation exposure on health. Lancet, 2015, vol. 386, no. 9992, pp. 469-78. DOI: $10.1016 / \mathrm{S} 0140-6736(15) 61167-9$

20. Grant E.J., Furukawa K., Sakata R., Sugiyama H., Sadakane A., Takahashi I., Utada M., Shimizu Y. [et al.]. Risk of death among children of atomic bomb survivors after 62 years of follow-up: a cohort study. Lancet Oncology, 2015, vol. 16, no. 13, pp. 1316-1323. DOI: 10.1016/S1470-2045(15)00209-0

21. Wakeford R. Childhood leukaemia and radiation exposure of fathers - the end of the road, perhaps? Journal of Radiological Protection, 2003, vol. 23, no. 4, pp. 359-362.

22. Vasilenko E.K. Dozimetriya vneshnego oblucheniya rabotnikov PO «Mayak»: pribory, metody, rezul'taty [Dosimetry of external radiation in PA "Mayak" workers: instruments, methods, results]. Istochniki i effekty oblucheniya rabotnikov $\mathrm{PO}$ «Mayak» i naseleniya, prozhivayushchego v zone vliyaniya predpriyatiya [The sources and the effects of exposure of PA "Mayak" workers and the population living in the zone of the enterprise influence]. In: M.F. Kiselev, S.A. Romanov, ed. Chelyabinsk, Chelyabinskii dom pechati Publ., 2009, Part 1, pp. 51-100 (in Russian).

23. Khokhryakov V.V., Khokhryakov V.F., Suslova K.G., Vostrotin V.V., Vvedensky V.E., Sokolova A.B., Krahenbuhl M.P., Birchall A. [et al.]. Mayak Worker Dosimetry System 2008 (MWDS-2008): 
assessment of internal dose from measurement results of plutonium activity in urine. Health Physics, 2013, vol. 104, no. 4, pp. 366-378.

24. Statisticheskaya klassifikatsiya boleznei, travm i prichin smerti (adaptirovannyi variant MKB-9 dlya ispol'zovaniya v SSSR). Izdanie 2-e. [Statistical classification of diseases, injuries and causes of death (adapted version of the ICD-9 for use in the USSR). Edition 2, Moscow, 1986, 97 p. (in Russian).

25. Mezhdunarodnaya statisticheskaya klassifikatsiya boleznei i problem, svyazannykh so zdorov'em. Desyatyi peresmotr, tom 1 (chast' 2) [International Statistical Classification of Diseases and Related Health Problems, Tenth Revision, vol. 1]. Moscow: Meditsina Publ., 1995, 633 p. (in Russian).

26. Preston D.L., Lubin J.H., Pierce D.A. McConney M. EPICURE user's Guide. Seattle, Hirosoft International Corporation Publ., 1993, 330 p.

27. Zhukovskaya E.V., Spichak I.I., Basharova E.V., Volosnikov D.K., Kovalenko S.G., Ogoshkova I.A. Zabolevaemost' ostrymi leikozami i ikh rasprostranennost' $\mathrm{v}$ detskoi populyatsii Chelyabinskoi oblasti za period 1974-2003 gg. [The incidence of acute leukemia and their prevalence in the children's population of the Chelyabinsk region for the period 1974-2003]. Voprosy gematologii/onkologii i immunopatologii v pediatrii, 2005, vol. 4, no. 1, pp. 20-24 (in Russian).

28. Men' T.Kh., Rykov M.Iu., Poliakov V.G. Zlokachestvennye novoobrazovaniya u detei v Rossii: osnovnye pokazateli i tendentsii [Malignant neoplasms in children in Russia: main indicators and trends]. Rossiiskii onkologicheskii zhurnal, 2015, vol. 20, no. 2, pp. 43-47 (in Russian).

29. Koterov A.N. Novye fakty ob otsutstvii induktsii nestabil'nosti genoma pri malykh dozakh radiatsii s nizkoi LPE i sootvetstvuyushchie vyvody o poroge effekta v soobshchenii NKDAR-2012 [New facts about the absence of induction of genome instability at low doses of radiation with low LET and the corresponding conclusions about the threshold effect in the message UNSCEAR - 2012]. Radiatsionnaya biologiya. Radioekologiya, 2014, vol. 54, no. 3, pp. 309-312 (in Russian).

30. Hwee J., Tait C., Sung L., Kwong J.C., Sutradhar R., Pole J.D. A systematic review and metaanalysis of the association between childhood infections and the risk of childhood acute lymphoblastic leukaemia. British Journal of Cancer, 2018, vol. 118, no. 1, pp. 127-137. DOI: 10.1038/bjc.2017.360

31. Miligi L., Benvenuti A., Mattioli S., Salvan A., Tozzi G.A., Ranucci A., Legittimo P., Rondelli R. [et al.]. Risk of childhood leukaemia and non-Hodgkin's lymphoma after parental occupational exposure to solvents and other agents: the SETIL Study. Occupational and Environmental Medicine, 2013, vol. 70, no. 9, pp. 648-655. DOI: 10.1136/oemed-2012-100951

32. Crump C., Sundquist J., Sieh W., Winkleby M.A., Sundquist K. Perinatal and familial risk factors for acute lymphoblastic leukemia in a Swedish national cohort. Cancer, 2015, vol. 121, no. 7, pp. 1040-1047.

33. Tabrizi M.M., Hosseini S.A. Role of Electromagnetic Field Exposure in Childhood Acute Lymphoblastic Leukemia and No Impact of Urinary Alpha- Amylase - a Case Control Study in Tehran, Iran. Asian Pacific Journal of Cancer Prevention, 2015, vol. 16, no. 17, pp. 7613-7618.

34. Magnani C., Mattioli S., Miligi L., Ranucci A., Rondelli R., Salvan A., Bisanti L., Masera G. [et al.]. SETIL: Italian multicentric epidemiological case-control study on risk factors for childhood leukaemia, non hodgkin lymphoma and neuroblastoma: study population and prevalence of risk factors in Italy. Italian Journal of Pediatrics, 2014, vol. 40, 103 p. DOI: 10.1186/s13052-014-0103-5

35. Draper G. Preconception exposures to potential germ-cell mutagens. Radiation Protection Dosimetry, 2008, vol. 132, no. 2, pp. 241-245.

36. Johnson K.J., Alexander B.H., Doody M.M., Sigurdson A.J., Linet M.S., Spector L.G., Hoffbeck W., Simon S.L. [et al.]. Childhood cancer in the offspring born in 1921-1984 to US radiologic technologists. British Journal of Cancer, 2008, vol. 99, no. 3, pp. 545-550.

37. Sosnina S.F., Kabirova N.R., Sokolnikov M.E., Okatenko P.V. Gemoblastozy u potomkov rabotnikov radiatsionno opasnykh proizvodstv [Hemoblastoses in offspring of radiationhazardous industries workers]. Analiz riska zdorov'yu, 2016, no. 4, pp. 23-30. DOI: 10.21668/health.risk/2016.4.03.eng (in Russian).

Sosnina S.F., Kabirova N.R., Sokolnikov M.E., Okatenko P.V. The risk of oncohematological pathology in children of workers employed at radiation-hazardous production. Health Risk Analysis, 2019, no. 1, pp. 30-39. DOI: 10.21668/health.risk/2019.1.03.eng

Received: 09.10.2018

Accepted: 19.01.2019

Published: 30.03.2019 
UDC 616.33-006.6

DOI: 10.21668/health.risk/2019.1.04.eng

\title{
RISK OF MORBIDITY WITH STOMACH CANCER AMONG WORKERS EMPLOYED AT RADIATION-HAZARDOUS ENTERPRISE
}

\author{
G.V. Zhuntova, E.S. Grigor'eva, T.V. Azizova
}

The Southern Urals Biophysics Institute of the RF Federal Medical and Biological Agency, 19 Ozerskoe drive, Ozersk, 456780, Russian Federation

We performed retrospective research among a cohort made up of workers employed at "Mayak" Production Association (Mayak PA), a state nuclear enterprise, who had been exposed to long-term external gamma-irradiation and internal alpha-irradiation caused by plutonium-239 under inhalation introduction. Our research goal was to assess impacts exerted by occupational irradiation and non-radiation factors on a risk of morbidity with stomach cancer (SC) in workers employed at Mayak PA.

We used individual data on occupational irradiation doses obtained from "Dosimetric system for Mayak PA workers - 2008" for external gamma-irradiation, and "Dosimetric system for Mayak PA workers - 2013" for internal alpha-irradiation. We applied Poisson regression to calculated odds ratio (OR) for morbidity with stomach cancer among the examined cohort both for radiation and non-radiation factors.

We detected statistically significant influence exerted on risk of morbidity with SC among workers employed at Mayak PA by the following factors: age, sex, attitudes towards to smoking and alcohol intake, stomach and duodenum ulcer, and external gamma-irradiation. Taking into account adjustments as per non-radiation factors, we detected a statistically significant increase in OR of morbidity with SC which was equal to 1.48 (95\% CI 1.10; 1.98), when a dose of external gamma-irradiation accumulated in the stomach walls was more than $1.0 \mathrm{~Gy}$. We didn't detect any correlation between risk of morbidity with CS among the examined cohort and internal alpha-irradiation.

Given that data obtained in epidemiologic research concerning impacts exerted by occupational irradiation on SC risks are ambiguous, it is necessary to clarify the obtained results and to perform more profound analysis of dose - response relationship among a more extended cohort of workers employed at Mayak PA.

Key words: morbidity risk, stomach cancer, gamma-irradiation, alpha-irradiation, smoking, alcohol, ulcer, dose - response relationship.

Stomach cancer is among the most widely spread malignant neoplasms though over the last decades there has been a slight decrease in morbidity and mortality caused by it in most countries all over the world, including Russia $[1,2]$. Stomach cancer is a polyetiologic disease that occurs due to complicated interaction between environmental factors, and impacts exerted by this interaction to a great extent depend on genetically determined peculiarities of a body [3].

Infection with Helicobacterpylori (H. pylori), nutrition, and alcohol intake are considered to be the basic risk factors that cause stomach cancer [4-6]. About $10 \%$ of stomach cancer cases among population are caused by inherited susceptibility to the disease [7]. Certain industrial agents (asbestos, chromium, nickel, coal, aromatic hydrocarbons, etc.) were shown to also contribute into stomach cancer etiology [8-11].

Influence exerted by ionizing irradiation on morbidity and mortality caused by stomach cancer was revealed in epidemiologic research performed among people living in Hiroshima and Nagasaki who had survived the atomic bombing as well as among patients who had undergone radiation therapy [12-19]. Workers employed at the nuclear enterprise Mayak PA

(C) Zhuntova G.V., Grigor'eva E.S., Azizova T.V., 2019

Galina V. Zhuntova - Candidate of Medical Sciences, Leading Researcher; Clinical Department (e-mail: clinic@subi.su; tel.: +7 (351) 302-95-41; ORCIDID: http://orcid.org/0000-0003-4407-3749).

Evgenia S. Grigor'eva - Researcher, Clinical Department (e-mail: clinic@subi.su; tel.: +7 (351) 302-93-73; ORCIDID: http://orcid.org/0000-0003-1806-9922).

Tamara V. Azizova - Candidate of Medical Sciences, Deputy Director responsible for Research, Head of the Clinical Department (e-mail: clinic@subi.su; tel.: +7 (351) 302-91-90; ORCIDID: http://orcid.org/0000-0001-6954-2674). 
and exposed to long-term irradiation turned out to run elevated risks of malignant neoplasms; however, data related to stomach cancer are rather ambiguous [20-22]. Up to now, a period of observations performed on Mayak PA workers has been extended considerably and there are new improved techniques for assessing doses of occupational internal alphairradiation [23] and it creates better conditions for refining previously obtained results on influence exerted by ionizing irradiation on stomach cancer risk.

Our research goal was to assess influence exerted by occupational irradiation and nonradiation factors on stomach cancer morbidity over 1948-2013 among workers employed at basic enterprises belonging to Mayak PA.

Data and methods. We performed our research among workers who were first employed by basic Mayak PA works (reactor, radiochemical, and plutonium one) in 1948-1982; the cohort included 22,377 people, $25 \%$ of them were women. The observation period started on a day when a worker was employed and lasted till December 31, 2013 (or until a day when stomach cancer was diagnosed or a day of death if it happened before this date) or till the last date on which medical information about a person was available (for those who moved somewhere and ceased to be observed). As on December 31, 2013, life status was detected for $95 \%$ of cohort members; $62 \%$ of them were dead. Average age $( \pm$ standard deviation) at the moment of death was equal to $61.5 \pm 13.6$ for men, and to $70.5 \pm 12.4$ for women; average age of those who were alive at the end of December 2013 amounted to $68.5 \pm 10.4$ for men; and to $76.6 \pm 9.8$, for women.

Personnel employed at all the basic works of Mayak PA were exposed to general external gamma-irradiation, and those who were employed at radiochemical and plutonium works were additionally exposed to alpha-active aerosols of plutonium-239. In our research we used estimations of occupational irradiation doses calculated on the basis of up-to-date dosimetric systems, "Dosimetric system for Mayak PA workers - 2008" for external gamma-irradiation doses and
"Dosimetric system for Mayak PA workers 2013" for doses of internal alpha-irradiation caused by incorporated plutonium [23, 24].

External irradiation has been monitored since PA Mayak started its operations and individual gamma-irradiation doses are known for each worker. Monitoring over internal irradiation has been introduced gradually since the late 1960ties; therefore, internal alpha-irradiation doses are detected for $31 \%$ workers exposed to plutonium-239 aerosol at their work places as the activity of this nuclide in their urine has been measured $[23,24]$. 55\% workers in the examined cohort were employed by Mayak PA in 1948-1958 when radiation exposure on personnel was the highest. Most workers (81\%) started their work at the enterprise when they were younger than 30 .

Data on diseases that workers had during the observation period were collected for 21,740 cohort members (97\%); attitudes to smoking (93\% workers) and its quantitative characteristics (71\% workers) were known for most of them, as well as attitudes towards alcohol intake ( $85 \%$ workers).

To perform an integral assessment of how long and intense smoking was, we applied smoking index (SI) calculated as per the following formula: SI = number of cigarettes packs smoked a day $\times$ duration of smoking (pack $\times$ years). Workers who consumed alcohol in rather large doses every day or had chronic alcoholism in their case history as per data obtained from addiction clinics were ranked as those who abused alcohol.

Besides, we examined influences exerted on morbidity with stomach cancer by the following diseases in the digestive system: stomach ulcer, duodenum ulcer, gastritis, duodenitis, malignant neoplasms in the stomach (codes K25-K26, K29, D13.1 of the ICD-10). All the above-mentioned diseases were taken into account only if they had been detected not later than 2 years prior to stomach cancer was diagnosed (to the end of the observation over the cohort); it was done in order to exclude an already existing but not diagnosed tumor process which can have similar symptoms at its early stages. 
Odds ratio (OR) for non-radiation factors was calculated on the basis of Poisson regression with corrections for attained age and sex. When calculating OR which was related to occupational irradiation, we took into account corrections for smoking status, alcohol intake, and occurrence of stomach and duodenum ulcer. Besides, when OR related to external gammairradiation was calculated, we made a correction for internal irradiation caused by incorporated plutonium; workers who weren't covered with monitoring over alpha-irradiation were attributed into a separate category. Analysis of stomach cancer risk caused by internal alphairradiation was performed only for workers who underwent procedures for control over plutonium contents in their bodies; the analysis was accomplished taking into account corrections for external gamma-irradiation doses.

All the calculations were made with AMFIT module of EPICURE software [25]. Discrepancies were considered to be statistically significant at $p<0.05$. External gammairradiation doses and internal alpha-irradiation doses absorbed in the stomach walls as well as smoking index were considered to be timedependent variables. Smoking status and smoking index value, as well as attitudes towards alcohol intake were taken at the moment when the observation over the cohort was over (or stomach cancer was diagnosed).

Results and discussion. Our research included 343 stomach cancer cases (280 men and 63 women) diagnosed in workers from the examined cohort during a period from the moment they had started working at basic Mayak PA plants to December 31, 2013. 248 workers $(72 \%)$ had the stomach cancer diagnosis confirmed by histology results; in all other cases it was confirmed by clinical data.

Workers who suffered from stomach cancer had average total external irradiation dose absorbed in the stomach wall $\pm \mathrm{SD}$ equal to $0.66 \pm 0.83$ Gy which was higher than among the examined cohort overall $(0.46 \pm 0.66 \mathrm{~Gy})$. Discrepancies in internal alpha-irradiation doses absorbed in the stomach walls which were equal to $0.0012 \pm 0.0026$ Gy in patients with stomach cancer and $0.0014 \pm 0.0064$ Gy in the cohort overall were not so significant. Distribution of stomach cancer cases and workers in the examined cohort depending on occupational irradiation doses is shown on Figures 1 and 2.

OR for stomach cancer morbidity was lower for women than for men and amounted to 0.35 (95\% CI 0.27; 0.46) (Table 1). Risk of stomach cancer in the examined cohort depended on an attained age. We revealed a statistically significant OR decrease among workers younger than 40 against those aged $40-45$ and growing OR in older age categories (after 50). Maximum OR value for stomach cancer morbidity in the examined cohort was detected for people older than 70 and was equal to $7.53(95 \%$ CI $4.84 ; 12.22$ ) (Table 1 ).

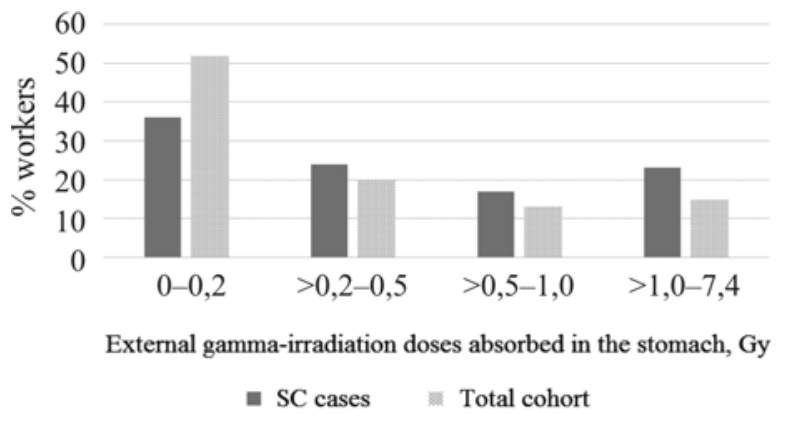

Figure 1. Distribution of workers in the examined cohort and stomach cancer cases depending on total external gamma-irradiation doses absorbed in the stomach walls

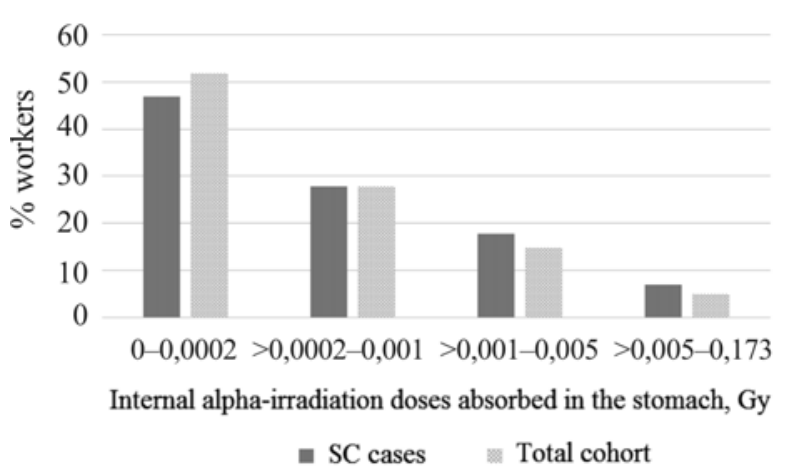

Figure 2. Distribution of workers in the examined cohort and stomach cancer cases depending on total internal alpha-irradiation doses absorbed in the stomach walls 
Table 1

Influence exerted by sex, age and a calendar period when a tumor was diagnosed on stomach cancer risk in the examined cohort

\begin{tabular}{|c|c|c|c|}
\hline Factor & Number of cases & Person-years of observation & OR $(95 \% \mathrm{CI})$ \\
\hline \multicolumn{4}{|l|}{ Sex: } \\
\hline men & 280 & 396,205 & 1 \\
\hline women & 63 & 168,459 & $0.35(0.27 ; 0.46)$ \\
\hline \multicolumn{4}{|c|}{ Age at which stomach cancer was diagnosed, years: } \\
\hline$<20$ & 0 & 9,616 & - \\
\hline$[20-25)$ & 0 & 44,885 & - \\
\hline$[25-30)$ & 5 & 59,589 & $0.22(0.07 ; 0.53)$ \\
\hline$[30-35)$ & 9 & 60,124 & $0.39(0.17 ; 0.82)$ \\
\hline$[35-40)$ & 11 & 61,104 & $0.48(0.23 ; 0.96)$ \\
\hline$[40-45)$ & 23 & 62,346 & 1 \\
\hline$[45-50)$ & 30 & 61,045 & $1.34(0.78 ; 2.34)$ \\
\hline$[50-55)$ & 41 & 55,271 & $2.06(1.25 ; 3.48)$ \\
\hline$[55-60)$ & 48 & 46,315 & $2.94(1.81 ; 4.91)$ \\
\hline$[60-65)$ & 53 & 37,395 & $4.12(2.56 ; 6.85)$ \\
\hline$[65-70)$ & 36 & 28,758 & $3.77(2.25 ; 6.45)$ \\
\hline$[70+$ & 87 & 38,216 & $7.53(4.84 ; 12.22)$ \\
\hline \multicolumn{4}{|c|}{ A calendar period during which stomach cancer was diagnosed: } \\
\hline $1948-1950$ & 0 & 7,623 & - \\
\hline $1951-1955$ & 7 & 31,331 & $1.77(0.71 ; 3.78)$ \\
\hline $1956-1960$ & 9 & 38,722 & $1.46(0.66 ; 2.91)$ \\
\hline $1961-1965$ & 9 & 47,408 & $0.91(0.41 ; 1.80)$ \\
\hline $1966-1970$ & 20 & 48,183 & $1.34(0.76 ; 2.26)$ \\
\hline $1971-1975$ & 25 & 50,294 & $1.15(0.69 ; 1.87)$ \\
\hline $1976-1980$ & 28 & 56,778 & $0.89(0.55 ; 1.42)$ \\
\hline $1981-1985$ & 43 & 59,105 & 1 \\
\hline $1986-1990$ & 30 & 55,262 & $0.54(0.34 ; 0.86)$ \\
\hline $1991-1995$ & 34 & 50,110 & $0.51(0.32 ; 0.80)$ \\
\hline $1996-2000$ & 47 & 43,925 & $0.62(0.41 ; 0.96)$ \\
\hline $2001-2005$ & 35 & 37,201 & $0.44(0.27 ; 0.69)$ \\
\hline $2006-2010$ & 34 & 28,785 & $0.44(0.27 ; 0.70)$ \\
\hline $2011-2013$ & 22 & 9,937 & $0.66(0.38 ; 1.12)$ \\
\hline
\end{tabular}

The obtained results are well in line with population data according to which stomach cancer is diagnosed 1.5-2.5 times more frequently in men than in women; experts think it can be due to different attitudes towards smoking, different nutrition, and different frequency of contacts with hazardous industrial factors [26]. It is also known that morbidity with stomach cancer taken for the overall population grows with age, especially among people older than 50, and reaches its peak among people aged 70-75 [2, 26].

We observed a statistically significant decrease in OR for stomach cancer morbidity in the examined cohort in 1986-2010 against 1981-1985 (Table 1). Morbidity with stomach cancer has decreased over last decades both in Russia and many other countries all over the world; in experts' opinion, it is due to changes in nutrition structure, lower frequency of infection with $H$. pylori, and lower prevalence of other risk factors that can cause stomach cancer, including improved working conditions $[1,2]$.

OR for stomach cancer morbidity was statistically significantly higher for smoking workers in the examined cohort and was equal to $1.57(95 \%$ CI $1.17 ; 2.13)$ as compared to 
those who didn't smoke (Table 2). A statistically significant increase in OR which was equal to $1.40(95 \%$ CI $1.03 ; 1.91)$ was also detected for smokers with SI greater than 20 pack $\times$ years. Besides, stomach cancer risk was statistically significantly higher for men who abused alcohol: OR $=2.00$ (95\% CI 1.22; 3.49) (Table 2).

Smoking is a well-known and well-proven risk factor that causes stomach cancer; according to meta-analysis data, it causes 1.5-1.6 times higher risk of the disease [27]. Alcohol abuse also contributes into stomach cancer etiology and it was revealed by meta-analysis and in large cohort research. There are data that intake of strong spirits in a dose higher than $60 \mathrm{~g}$ /day in terms of ethanol leads to 1.64 times higher stomach cancer risk [28]. Smoking, al- cohol intake and H.pylori infection were shown to interact in a synergic manner causing greater inflammation and elevated probability of malignant transformations in the stomach mucous tunic [29].

Russia is among countries where there is high prevalence of $H$. pylori, as $78.5 \%$ population in the country is infected with it [30]. However we, within our retrospective research, could only indirectly take into account the role played by this factor in stomach cancer etiology among workers employed at Mayak PA.

Clinical effects produced by $H$. pylori depend on localization and peculiarities of inflammation processes in the stomach [31]. H. pylori-associated atrophic gastritis and stomach ulcer are known to cause elevated stomach cancer risks [26, 31]. But at the same

Table 2

Influence exerted by smoking, alcohol intake, and chronic diseases on stomach cancer risk in the examined cohort

\begin{tabular}{|c|c|c|c|}
\hline Factor & $\begin{array}{l}\text { Number } \\
\text { of cases }\end{array}$ & $\begin{array}{c}\text { Person-years of the } \\
\text { observation }\end{array}$ & OR $(95 \% \mathrm{CI})$ \\
\hline \multicolumn{4}{|l|}{ Smoking, status: } \\
\hline never smoked & 111 & 241,531 & 1 \\
\hline gave up smoking & 67 & 112,659 & $0.77(0.54 ; 1.10)$ \\
\hline smoked & 159 & 201,964 & $1.57(1.17 ; 2.13)$ \\
\hline \multicolumn{4}{|l|}{ Smoking index, pack $\times$ years } \\
\hline never smoked & 111 & 241,531 & 1 \\
\hline$\leq 10$ & 15 & 76,748 & $0.60(0.33 ; 1.04)$ \\
\hline $10-20$ & 33 & 68,234 & $1.03(0.66 ; 1.57)$ \\
\hline$>20$ & 143 & 109,704 & $1.40(1.03 ; 1.91)$ \\
\hline \multicolumn{4}{|l|}{ Alcohol intake, status (men only): } \\
\hline didn't drink or did it rarely & 17 & 48,956 & 1 \\
\hline moderate drinkers & 146 & 242,713 & $1.36(0.85 ; 2.33)$ \\
\hline abused alcohol & 87 & 70,133 & $2.00(1.22 ; 3.49)$ \\
\hline \multicolumn{4}{|l|}{ Stomach ulcer: } \\
\hline no & 312 & 548,891 & 1 \\
\hline yes & 31 & 15,773 & $1.69(1.14 ; 2.42)$ \\
\hline \multicolumn{4}{|l|}{ Duodenum ulcer: } \\
\hline no & 326 & 535,042 & 1 \\
\hline yes & 17 & 29,623 & $0.49(0.29 ; 0.78)$ \\
\hline \multicolumn{4}{|l|}{ Gastritis and duodenitis: } \\
\hline no & 149 & 356,573 & 1 \\
\hline yes & 194 & 208,091 & $1.23(0.98 ; 1.54)$ \\
\hline \multicolumn{4}{|l|}{ Stomach polyps: } \\
\hline no & 338 & 561,803 & 1 \\
\hline yes & 5 & 2,861 & $1.18(0.42 ; 2.58)$ \\
\hline
\end{tabular}


time, when a patient suffers from duodenum ulcer or chronic gastritis with the increased secretory function, he or she runs lower stomach cancer risks $[26,31]$.

We detected a statistically significant increase in stomach cancer risk which was equal to $1.69(95 \%$ CI $1.14 ; 2.42)$ in the examined cohort for workers who suffered from stomach ulcer against those who didn't have this disease (Table 2). But in case a worker had duodenum ulcer, he or she, on the contrary, ran lower stomach cancer risk with OR $=0.49(95 \%$ CI $0.29 ; 0.78)$. We revealed a slight increase in OR for workers who suffered from gastritis and duodenitis and its estimation was close to the statistical significance boundary $(p<0.1)$. We didn't reveal any statistically significant correlation between stomach polyposis and stomach cancer among workers from the examined cohort but there were few cases of this disease (Table 2).

The performed analysis revealed a statistically significant increase in OR for stomach cancer morbidity when external gamma-irradiation doses absorbed in the stomach walls were higher than 1.0 Gy against those workers who had external irradiation doses not higher than 0.2 Gy (Table 3). Estimation of OR for stomach cancer morbidity calculated with corrections for sex, age, and alpha-irradiation, amounted to 1.37 (95\% CI 1.02; 1.83). We introduced additional corrections for smoking status, attitudes towards alcohol, and occurrence of stomach and duodenum ulcer, and OR estimation went up slightly to $1.48(95 \%$ CI 1.10 ; 1.98) (Table 3).

Table 3

Influence exerted by long-term total external gamma-irradiation on stomach cancer risk in the examined cohort

\begin{tabular}{|c|c|c|c|}
\hline $\begin{array}{l}\text { External gamma-irradiation dose } \\
\text { absorbed in the stomach walls, Gy }\end{array}$ & $\begin{array}{l}\text { Number } \\
\text { of cases }\end{array}$ & $\begin{array}{l}\text { Person-years } \\
\text { of the observation }\end{array}$ & OR $(95 \% \mathrm{CI})$ \\
\hline \multicolumn{4}{|c|}{ Model with corrections for sex, age, and alpha-irradiation: } \\
\hline$[0.0-0.2)$ & 123 & 284,928 & 1 \\
\hline$[0.2-0.5)$ & 83 & 107,64 & $1.26(0.95 ; 1.66)$ \\
\hline$[0.5-1.0)$ & 58 & 71,608 & $1.24(0.89 ; 1.69)$ \\
\hline$[1.0+$ & 79 & 82,125 & $1.37(1.02 ; 1.83)$ \\
\hline \multicolumn{4}{|c|}{ Model with corrections for sex, age, smoking status, and alpha-irradiation: } \\
\hline$[0.0-0.2)$ & 123 & 284,928 & 1 \\
\hline$[0.2-0.5)$ & 83 & 107,464 & $1.27(0.96 ; 1.68)$ \\
\hline$[0.5-1.0)$ & 58 & 71,608 & $1.26(0.91 ; 1.72)$ \\
\hline$[1.0+$ & 79 & 82,125 & $1.44(1.07 ; 1.93)$ \\
\hline \multicolumn{4}{|c|}{ Model with corrections for sex, age, smoking status, alcohol intake, and alpha-irradiation: } \\
\hline$[0.0-0.2)$ & 123 & 284,928 & 1 \\
\hline$[0.2-0.5)$ & 83 & 107,464 & $1.29(0.97 ; 1.70)$ \\
\hline$[0.5-1.0)$ & 58 & 71,608 & $1.29(0.93 ; 1.76)$ \\
\hline$[1.0+$ & 79 & 82,125 & $1.47(1.09 ; 1.97)$ \\
\hline \multicolumn{4}{|c|}{ Model with corrections for sex, age, smoking status, alcohol intake, stomach ulcer, and alpha-irradiation } \\
\hline$[0.0-0.2)$ & 123 & 284,928 & 1 \\
\hline$[0.2-0.5)$ & 83 & 107,464 & $1.28(0.96 ; 1.70)$ \\
\hline$[0.5-1.0)$ & 58 & 71,608 & $1.28(0.93 ; 1.75)$ \\
\hline$[1.0+$ & 79 & 82,125 & $1.47(1.09 ; 1.96)$ \\
\hline \multicolumn{4}{|c|}{$\begin{array}{l}\text { Model with corrections for sex, age, smoking status, alcohol intake, stomach ulcer, duodenum ulcer, } \\
\text { and alpha-irradiation: }\end{array}$} \\
\hline$[0.0-0.2)$ & 123 & 284,928 & 1 \\
\hline$[0.2-0.5)$ & 83 & 107,464 & $1.29(0.97 ; 1.71)$ \\
\hline$[0.5-1.0)$ & 58 & 71,608 & $1.29(0.93 ; 1.76)$ \\
\hline$[1.0+$ & 79 & 82,125 & $1.48(1.10 ; 1.98)$ \\
\hline
\end{tabular}


Table 4

Influence exerted by long-term total internal alpha-irradiation on stomach cancer risk in the examined cohort

\begin{tabular}{|c|c|c|c|}
\hline $\begin{array}{l}\text { Internal alpha-irradiation dose absorbed } \\
\text { in the stomach walls, Gy }\end{array}$ & $\begin{array}{c}\text { Number of } \\
\text { cases }\end{array}$ & $\begin{array}{l}\text { Person-years of the } \\
\text { observation }\end{array}$ & OR $(95 \% \mathrm{CI})$ \\
\hline \multicolumn{4}{|c|}{ Model with corrections for sex, age, and gamma-irradiation: } \\
\hline$[0.0-0.2)$ & 101 & 219,531 & 1 \\
\hline$[0.2-0.5)$ & 57 & 64,106 & $0.95(0.66 ; 1.35)$ \\
\hline$[0.5-1.0)$ & 35 & 27,361 & $1.04(0.66 ; 1.61)$ \\
\hline$[1.0+$ & 10 & 6,727 & $1.26(0.59 ; 2.42)$ \\
\hline \multicolumn{4}{|c|}{ Model with corrections for sex, age, smoking status, and gamma-irradiation: } \\
\hline$[0.0-0.2)$ & 101 & 219,531 & 1 \\
\hline$[0.2-0.5)$ & 57 & 64,106 & $0.93(0.65 ; 1.32)$ \\
\hline$[0.5-1.0)$ & 35 & 27,361 & $1.03(0.65 ; 1.60)$ \\
\hline$[1.0+$ & 10 & 6,727 & $1.26(0.59 ; 2.42)$ \\
\hline \multicolumn{4}{|c|}{ Model with corrections for sex, age, smoking status, alcohol intake, and gamma-irradiation: } \\
\hline$[0.0-0.2)$ & 101 & 219,531 & 1 \\
\hline$[0.2-0.5)$ & 57 & 64,106 & $0.93(0.65 ; 1.32)$ \\
\hline$[0.5-1.0)$ & 35 & 27,361 & $1.03(0.65 ; 1.60)$ \\
\hline$[1.0+$ & 10 & 6,727 & $1.24(0.58 ; 2.39)$ \\
\hline \multicolumn{4}{|c|}{ Model with corrections for sex, age, smoking status, alcohol intake, stomach ulcer, and gamma-irradiation } \\
\hline$[0.0-0.2)$ & 101 & 219,531 & 1 \\
\hline$[0.2-0.5)$ & 57 & 64,106 & $0.93(0.65 ; 1.31)$ \\
\hline$[0.5-1.0)$ & 35 & 27,361 & $1.03(0.65 ; 1.60)$ \\
\hline$[1.0+$ & 10 & 6,727 & $1.24(0.58 ; 2.41)$ \\
\hline \multicolumn{4}{|c|}{$\begin{array}{l}\text { Model with corrections for sex, age, smoking status, alcohol intake, stomach ulcer, duodenum ulcer, } \\
\text { and gamma-irradiation: }\end{array}$} \\
\hline$[0.0-0.2)$ & 101 & 219,531 & 1 \\
\hline$[0.2-0.5)$ & 57 & 64,106 & $0.92(0.64 ; 1.31)$ \\
\hline$[0.5-1.0)$ & 35 & 27,361 & $1.02(0.65 ; 1.59)$ \\
\hline$[1.0+$ & 10 & 6,727 & $1.20(0.56 ; 2.31)$ \\
\hline
\end{tabular}

We didn't detect any influence exerted by internal alpha-irradiation on stomach cancer risk in the examined cohort (Table 4) and the result is well in line with the previously obtained ones [20-22]. Other researchers also didn't reveal any carcinogenic effects in the stomach when alpha-irradiators ( $\mathrm{Ra}, \mathrm{Th}, \mathrm{Rn}$, $\mathrm{Pu})$ were introduced in a body; it is most frequently explained by rather insignificant doses of such irradiation absorbed in this organ [32-34].

Previously experts who had conducted "case - control" research on workers employed at Mayak PA revealed an elevated stomach cancer risk when total external gammairradiation doses were higher than 3.0 Gy [20]. Cohort research performed on workers employed at basic Mayak PA plants revealed increased risks of morbidity (observation period 1948-2004) [21] and mortality (observation period 1948-2008) caused by stomach cancer when external gamma-irradiation doses grew [22]; however, estimations of excessive relative risks were only close to the statistical significance boundary $(\mathrm{p}<0.07$ and $<0.06$ accordingly).

We prolonged the observation period up to 2013 within the framework of our research; also, when assessing influence exerted by occupational irradiation on stomach cancer risk, we took into account a wider range of non-radiation factors including chronic stomach diseases that can be caused by infection with $H$. pylori.

Research performed on people who had survived the atomic bombing in Japan revealed a dependence between a dose of acute gamma- 
neutron irradiation and risks of morbidity and mortality caused by stomach cancer $[12,13]$. Elevated stomach cancer risks were also detected for patients who had undergone radiation therapy or had had ${ }^{131}$ I introduced into their bodies when hyperthyrosis had been treated $[14-19,35]$.

But a lot of researchers who examined personnel employed at nuclear enterprises in foreign countries, people living on territories contaminated with radiation emissions and in zones where natural radiation background was a bit increased didn't obtain any convincing evidence that there was a correlation between long-term irradiation in small doses and stomach cancer risk [36-39]. However, an elevated stomach cancer risk caused by exposure to radiation was revealed for a combined cohort of workers employed at nuclear enterprises in France, Great Britain, and the USA, when average external gamma-irradiation doses absorbed in the stomach were equal to $20 \mathrm{mGy}$ [40].

Conclusion. The research performed on workers employed at Mayak PA revealed an elevated stomach cancer risk under long-term external gamma-irradiation in total doses ab- sorbed in the stomach walls equal to more than 1.0 Gy. Given the fact that data on influence exerted by occupational irradiation on stomach cancer risks that have been accumulated so far are rather ambiguous, it is necessary to analyze a dose-effect relationship in greater detail and on an extended cohort of workers employed at Mayak PA.

We didn't reveal any influence exerted by long-term internal alpha-irradiation on stomach cancer morbidity in workers employed at Mayak PA.

Stomach cancer risk for the examined cohort, just as for overall population, depended on an attained age, sex, attitudes towards smoking and alcohol intake, as well as on occurrence of stomach and duodenum ulcer.

Funding sources. The present research has been accomplished within the frameworks of the Agreement No. 501-1-18 "Effects produced by chronic irradiation" signed on July 23, 2018 with the Urals Scientific and Practical Center for Radiation Medicine of the Federal Biomedical Agency

Conflict of interests. The authors state there is no any conflict of interests.

\section{References}

1. Balakrishnan M., George R., Sharma A., Graham D.Y. Changing Trends in Stomach Cancer Throughout the World. Current Gastroenterology Reports, 2017, vol. 19, no. 8, 36 p. DOI: $10.1007 / \mathrm{s} 11894-017-0575-8$

2. Zlokachestvennye novoobrazovaniya v Rossii v 2013 godu (zabolevaemost' i smertnost') [Malignantneoplasms in Russian 2013 (morbidity and mortality)]. In: A.D. Kaprin, V.V. Starinskii, G.V. Petrova eds. Moscow, MNIOI im. P.A. Gertsena Publ., 2015, 250 p. (in Russian).

3. Shi J., Qu Y-P., Hou P. Pathogenetic mechanisms in gastric cancer. World Journal of Gastroenterology, 2014, vol. 20, no. 38, pp. 13804-13819. DOI: 10.3748/wjg.v20.i38.13804

4. Eusebi L.H., Zagari R.M., Bazzoli F. Epidemiology of Helicobacter pylori infection. Helicobacter, 2014, no. 19, suppl. 1, pp. 1-5. DOI: 10.1111/hel.12165

5. Agudo A., Cayssials V., Bonet C. [et al.]. Inflammatory potential of the diet and risk of gastric cancer in the European Prospective Investigation into Cancer and Nutrition (EPIC) study. The American Journal of Clinical Nutrition, 2018, vol. 107, no. 4, pp. 607-616.

6. Sinha D.N., Suliankatchi R.A., Gupta P.C, [et al.]. Global burden of all-cause and cause-specific mortality due to smokeless tobacco use: systematic review and meta-analysis. Tobacco Control, 2018, vol. 27, no. 1, pp. 35-42. DOI: 10.1136/tobaccocontrol-2016-053302

7. McLean M.H., El-Omar E.M. Genetics of gastric cancer. Nature Reviews Gastroenterology \& Hepatology, 2014, no. 11, pp. 664-674. DOI: 10.1038/nrgastro.2014.143

8. Saghier A.A., Kabanja J.H., Afreen S., Sagar M. Gastric cancer: Environmental risk factors, treatment and prevention. Journal of Carcinogenesis and Mutagenesis, 2013, № S14:008. DOI: 10.4172/2157-2518

9. Welling R., Beaumont J.J., Petersen S.J. [et al.]. Chromium VI and stomach cancer: a metaanalysis of the current epidemiological evidence. Occupational and Environmental Medicine, 2015, vol. 72, no. 2, pp. 151-159. DOI: 10.1136/oemed-2014-102178 
10. Boniol M., Koechlin A., Boyle P. Meta-analysis of occupational exposures in the rubber manufacturing industry and risk of cancer. International Journal of Epidemiology, 2017, vol. 46, no. 6, pp. 1940-1947. DOI: 10.1093/ije/dyx146

11. Di Ciaula A. Asbestos ingestion and gastrointestinal cancer: a possible underestimated hazard. Expert Review of Gastroenterology \& Hepatology, 2017, vol. 11, no. 5, pp. 419-425. DOI: 10.1080/17474124.2017

12. Preston D.L., Ron E., Tokuoka S. [et al.]. Solid Cancer Incidence in Atomic Bomb Survivors: 1958-1998. Radiation Research, 2007, vol. 168, no. 1, pp. 1-64.

13. Ozasa K., Shimizu Y., Suyama A. [et al.]. Studies of the mortality of atomic bomb survivors, Report 14, 1950-2003: an overview of cancer and non-cancer diseases. Radiation Research, 2012, vol. 177 , no. 3 , pp. $229-243$.

14. Gilbert E.S., Curtis R.E., Hauptmann M. [et al.]. Stomach Cancer Following Hodgkin Lymphoma, Testicular Cancer and Cervical Cancer: A Pooled Analysis of Three International Studies with a Focus on Radiation Effects. Radiation Research, 2017, no. 187, pp. 186-195.

15. Morton L.M., Dores G.M., Curtis R.E. [et al.]. Stomach cancer risk after treatment for Hodgkin lymphoma. Journal of Clinical Oncology, 2013, no. 31, pp. 3369-3377.

16. Hauptmann M., Fossa S.D., Stovall M., von Leeuwen F.E. [et al.]. Increased stomach cancer risk following radiotherapy for testicular cancer. British Journal of Cancer, 2015, no. 112, pp. 44-51.

17. Kleinerman R.A., Smith S.A., Holowaty E. [et al.]. Radiation dose and subsequent risk for stomach cancer in long-term survivors of cervical cancer. International Journal of Radiation Oncology, Biology, Physics, 2013, no. 86, pp. 922-929.

18. Little M.P., Stovall M., Smith S.A., Kleinerman R.A., A reanalysis of curvature in the dose response for cancer and modifications by age at exposure following radiotherapy for benign disease. International Journal of Radiation Oncology, Biology, Physics, 2013, vol. 85, no. 2, pp. 451-459. DOI: 10.1016/j.ijrobp.2012.04.029

19. Carr Z.A., Kleinerman R.A., Stovall M. [et al.]. Malignant neoplasms after radiation therapy for peptic ulcer. Radiation Research, 2002, vol. 157, no. 6, pp. 668-677.

20. Zhuntova G.V., Tokarskaya Z.B., Belyaeva Z.D. Vliyanie radiatsionnykh i neradiatsionnykh faktorov riska na zabolevaemost' rakom zheludka u rabotnikov PO «Mayak» [Influence of Radiation and Non-radiation Factors in Stomach Cancer Incidence among Mayak PA Workers]. Meditsinskaya radiologiya i radiatsionnaya bezopasnost', 2009, vol. 54, no. 2, pp. 38-46 (in Russian).

21. Hunter N., Kuznetsova I.S., Labutina E.V., Harrison J.D. Solid cancer incidence other than lung, liver and bone in Mayak workers: 1948-2004. British Journal of Cancer, 2013, vol. 109, no. 7, pp. 1989-1996.

22. Sokolnikov M., Preston D., Gilbert E. [et al.]. Radiation Effects on Mortality from Solid Cancers Other than Lung, Liver, and Bone Cancer in the Mayak Worker Cohort: 1948-2008. PLOS ONE, 2015, vol. 10, no. 2, p. e0117784.

23. Birchall A., Vostrotin V., Puncher M. [et al.]. The Mayak Worker Dosimetry System (MWDS-2013) for internally deposited plutonium: an overview. Radiation Protection Dosimetry, 2017, no. 176, pp. 10-31.

24. Vasilenko E.K., Khokhryakov V.F., Miller S.C. [et al.]. Mayak worker dosimetry study: an overview. Health Physics, 2007, vol. 93, no. 3, pp. 190-206.

25. Preston D.L., Lubin J.H., Pierce D.A., McConney M.E. Epicure Users Guide. Seattle, Washington: Hirosoft International Corporation Publ., 1993.

26. Guggenheim D.E., Shah M.A. Gastric cancer epidemiology and risk factors. Journal of Surgical Oncology, 2013, no. 107, pp. 230-236.

27. Ladeiras-Lopes R., Pereira A.K., Ngueira A. [et al.]. Smoking and gastric cancer: systematic review and meta-analysis of cohort studies. Cancer Causes and Control, 2008, no. 19, pp. 689-701.

28. Duell E.J., Travier N., Lujan-Barroso L. [et al.]. Alcohol consumption and gastric cancer risk in the European Prospective Investigation into Cancer and Nutrition (EPIC) cohort. The American Journal of Clinical Nutrition, 2011, no. 94, pp. 1266-1275.

29. Salaspuro M. Interrelationship between alcohol, smoking, acetaldehyde and cancer. Novartis Foundation symposium, 2007, no. 285, pp. 80-89.

30. Hooi J.K.Y., Lai W.Y., Ng W.K., Global Prevalence of Helicobacter pylori Infection: Systematic Review and Meta-Analysis. Gastroenterology, 2017, no. 153, pp. 420-429. DOI: 10.1053/j.gastro.2017.04.022 
31. White J.R., Winter J.A., Robinson K. Differential inflammatory response to Helicobacter pylori infection: etiology and clinical outcomes. Journal of Inflammation Research, 2015, no. 8, pp. 137-147.

32. Mori T., Kato Y., Hatakeyama S. [et al.]. Results of the first series of follow-up studies on Japanese Thorotrast patients and their relationships to an autopsy series. Radiation Research, 1999, vol. 152, no. 6 , pp. $72-80$.

33. Nekolla E.A., Kellerer A.M., Kuse-Isingschulte M. [et al.]. Malignancies in patients treated with high doses of Radium-224. Radiation Research, 1999, vol. 152, no. 6, pp. 3-7.

34. Omar R.Z., Barber J.A., Smith P.G. Cancer morbidity among plutonium workers at the Sellafield plant of British Nuclear Fuels. British Journal of Cancer, 1999, vol. 79, no. 7/8, pp. 1288-1301.

35. Holm L.E., Hall P., Wiklund K. [et al.]. Cancer risk after iodine-131 therapy for hyperthyroidism. Journal of the National Cancer Institute, 1991, vol. 83, no. 15, pp. 1072-1077.

36. Cardis E., Vrijheid M., Blettner M. [et al.]. The 15-Country Collaborative Study of Cancer Risk among Radiation Workers in the Nuclear Industry: estimates of radiation-related cancer risks. Radiation Research, 2007, vol. 167, no. 4, pp. 396-416.

37. Boice J.D. Jr., Sarah S., Cohen M.T. [et al.]. Updated Mortality Analysis of Radiation Workers at Rocketdyne (Atomics International), 1948-2008. Radiation Research, 2011, no. 176, pp. 244-258.

38. Metz-Flamant C., Samson E., Cae"r-Lorho S. [et al.]. Solid Cancer Mortality Associated with Chronic External Radiation Exposure at the French Atomic Energy Commission and Nuclear Fuel Company. Radiation Research, 2011, no. 176, pp. 115-127.

39. Tao Z., Cha Y., Sun Q. Cancer mortality in high background radiation area of Yangiiang, China, 1979-1995. Zhonghua Yi XueZaZhi, 1999, vol. 79, no. 7, pp. 487-492.

40. Richardsona D.B., Cardisb E., Danielse R.D. [et al.]. Site-specific Solid Cancer Mortality After Exposure to Ionizing Radiation: A Cohort Study of Workers (INWORKS). Epidemiology, 2018, vol. 29, no. 1, pp. 31-40. DOI: 10.1097/EDE.0000000000000761

Zhuntova G.V., Grigor'eva E.S., Azizova T.V. Risk of morbidity with stomach cancer among workers employed at radiation-hazardous enterprise. Health Risk Analysis, 2019, no. 1, pp. 40-49. DOI: 10.21668/health.risk/2019.1.04.eng

Received: 29.10 .2018

Accepted: 19.01.2019

Published: 30.03 .2019 
UDC 613.6.02

DOI: $10.21668 /$ health.risk/2019.1.05.eng

\title{
CONTEMPORARY WORKING CONDITIONS AND ASSESSMENT OF OCCUPATIONAL HEALTH RISK FOR WORKERS EMPLOYED AT FLOUR-GRINDING PRODUCTIONS
}

\author{
T.A. Novikova, Yu.A. Aleshina, A.N. Danilov, V.F. Spirin
}

Saratov scientific research institute of rural hygiene, 1a Zarechnaya Str., Saratov, 410022, Russian Federation

\begin{abstract}
The paper gives a complex hygienic characteristics of working conditions at typical contemporary flour-grinding productions which deal with grain processing. It is shown that workers who are employed at flour-grinding production and perform their work tasks at all the stages of technological cycle on grain processing are exposed to a set of adverse industrial factors related to their labor process. These factors create hazardous working conditions which are ranked as having the 2nd and the $3 r d$ hazard degree (3.2 and 3.3 categories) as per the Guide P 2.2.2006-05. Among primary factors which create hazardous working conditions we can mention flour dust; grain dust; industrial noise; adverse microclimate; labor hardness caused by overall high physical dynamic loads borne by arms, body, and legs; a necessity to stay in an inconvenient and forced working posture; constant moving related to maintenance of equipment and control over production processes. According to the Guide P 2.2.1766-03, categories of expected occupational health risk for workers are estimated to vary from average (substantial) risk to high (intolerable) one depending on functions performed by a worker. Working area air contamination with grain dust and flour dust are considered to be a priority health risk factor for workers employed at flourgrinding production. As we assessed occupational risks as per data obtained during periodical medical examinations, we detected an average authentic cause-and-effect relationship between working conditions factors and respiratory organs diseases $(R R=1.64 ; E F=39 \%, C I=0.5-4.5)$, which meant such diseases were occupationally induced. Basing on the performed research, we developed priority measures which can help to reduce occupational health risks for workers employed at flour-grinding production.
\end{abstract}

Key words: workers employed at flour-grinding production; adverse working conditions; occupational health risk.

Agricultural production is a key sphere in providing food security of any country; therefore, nowadays its development is a basic strategic task of the overall economic development in the Russian Federation. Flour-grinding production should be given special attention here since such food products as bread, grocery, macaroni, and cereals are manufactured out of grain and flour, and they traditionally account for a substantial part of an everyday ration consumed by population in Russia. Such products are indeed irreplaceable ${ }^{1}$. But still, most flour-grinding plants which operate in the country do not conform to any modern requirements in terms of their technical facilities. They were put into operation 30 or even 40 years ago and haven't undergone any substantial technical re-equipment since then; their basic production assets are out-of-date, and their wear and tear amounts to $62-70 \%$. Technologies applied at such plants are also out-of-date, and production is not automated enough [1], that results in adverse working conditions existing at most workplaces there.

(C) Novikova T.A., Aleshina Yu.A., Danilov A.N., Spirin V.F., 2019

Tamara A. Novikova - Candidate of Biological Sciences, Associate Professor, Head of Laboratory for Occupational Hygiene in Agriculture and Processing Industries (e-mail: novikovata-saratov@yandex.ru; tel.: +7 (905) 384-71-84; ORCID: https://orcid.org/0000-0003-0366-856X).

Yuliya A. Aleshina - Candidate of Biological Sciences, acting as Senior researcher at Laboratory for Occupational Hygiene in Agriculture and Processing Industries (e-mail: julita-80@mail.ru; tel.: +7 (845) 292-78-90).

Aleksei N. Danilov - Doctor of Medical Sciences, Associate Professor, Director (e-mail: niusgsar@mail.ru; tel.: +7 (845) 292-78-90).

Vladimir F. Spirin - Doctor of Medical Sciences, Professor, Head of Laboratory for Environmental Hygiene (e-mail: vlad.spirin2011@yandex.ru; tel.: +7 (845) 292-78-90).

${ }^{1}$ On the State program for the development of agriculture and regulation of markets for agricultural products, raw materials and food stuffs for 2013-2020: The RF Governmental Order dated July 14, 2012 N 717 [web-source]. - URL: http:// docs.cntd.ru/document/902361843 (date of visit February 18, 2018). 
According to a small number of scientific works available on the subject that were written at the end of the last century, working conditions at flour-grinding productions are related to several adverse industrial factors (grain dust, flour dust, in-plant noise, and uncomfortable microclimate) and labor process factors; these factors exert negative influence on workers' health [2-4]. Preliminary medical examinations revealed that workers employed at flour-grinding plants most frequently suffered from diseases in the respiratory organs, peripheral nervous system, musculoskeletal apparatus, cardiovascular system, and the gastrointestinal tract $[2,5]$. Most research concentrated on examining dustiness in working area air caused by grain and flour dusts, peculiarities of emergence and clinical course of respiratory organs diseases, as well as efficiency of their treatment [6-10].

There hasn't been any complex research on working conditions that exist at production plants dealing with grain processing into flour. We haven't been able to find sufficient data on occupational risk assessment for workers employed at flour-grinding productions. There are no current data on occupational hygiene in flour-grinding production and it makes it difficult to develop and update standards and procedures aimed at providing hygienically safe working conditions and preventing health disorders in workers employed in this socially significant sphere. All the above-stated proves our research is essentially vital.

Our research goal was to give a hygienic characteristics of working conditions and to assess occupational risks for the health of workers employed at contemporary flourgrinding production.

Data and methods. We chose the following research object: working conditions existing at two flour-grinding plants with their daily production capacity being equal to 250 tons; these two plants functioned as structural units of an ordinary grocery plant. We examined air dustiness in working zones, parameters of industrial microclimate in warm and cold seasons, in-plant noise, overall vibration, labor hardness and intensity at all the stages in the technological process of processing grain into flour.

We analyzed air dustiness via gravity determination of dust mass; dust was collected out of a carefully measured volume of the examined air. Samples were collected on analytical paper filters in zones where workers breathed; samples collecting lasted from 5 to 10 minutes at a speed equal to $20 \mathrm{dm}^{3} /$ minute. To obtain correct results at each sampling points, we repeated the collecting procedure 5 times. Mass concentration and component structure of dust were examined with conventional techniques and equipment. Assessment was performed as per average shift concentration of dust depending on how long a contact with it lasted and in full conformity with the existing hygienic standards. Disperse structure of dust was examined with PKVZ-905-1 air dustiness inspection tool, which is applied to automatically determine total solid particles count in an analyzed air volume $\left(1000 \pm 100 \mathrm{~cm}^{3}\right)$.

Microclimate parameters, noise and vibration were examined and assessed for standard technological processes in accordance with the Sanitary-Epidemiologic requirements No. 2.2.4.3359-16 entitled "Sanitary-Epidemiologic requirements to physical factors existing at workplaces" ${ }^{2}$. We applied measurement tools and procedures that were included into the State Register of measuring tools and that were properly calibrated.

We examined and assessed labor hardness and intensity in full conformity with P 2.2.2006-05 "Occupational hygiene. Guide on hygienic assessment of factors related to working environment and labor process. Criteria and classification of working conditions" (Supplements No. 15 and 16) ${ }^{3}$. Overall, we took 112 samples of dust, performed 376 examinations of

${ }^{2}$ 2.2.4.3359-16. Sanitary-epidemiologic requirements to physical factors existing at workplaces: Sanitary-epidemiologic rules and standards [web-source] // KODEKS: an electronic fund of legal and reference documentation. - URL: http://docs.cntd.ru/document/420362948 (date of visit April 11, 2018).

${ }^{3}$ P 2.2.2006-05. Guide on hygienic assessment of factors related to working environment and labor process. Criteria and classification of working conditions [web-source] // KODEKS: an electronic fund of legal and reference documentation. - URL: http://docs.cntd.ru/document/1200040973 (date of visit April 11, 2018). 
physical factors related to working environment, and analyzed 21 jobs to get an insight into the essence of labor process at various workplaces.

Structure and categories of occupational risk were analyzed and assessed in full conformity with P 2.2.1766-03 "Guide on occupational health risks assessment. Organizational and methodical grounds, assessment procedures and criteria" ${ }^{4}$.

We examined data of periodical medical examinations to assess workers' health; these examinations were performed by medical experts from Occupational Diseases Clinic at Rospotrebnadzor's Saratov Scientific Research Institute for Rural Hygiene. Our focus group was made up of 39 workers employed at grinding mills who were exposed to adverse industrial factors; their average age was $44.9 \pm 4.1$, and their average working experience in the sphere was $11.7 \pm 3.5$ years. Our reference group included 16 workers who were employed at plant offices and were not exposed to adverse industrial factors; their average age was $48.2 \pm 3.5$, and their average working experience amounted to $9.8 \pm 2.9$ years. Workers in our focus group were raw materials loaders and grinding production operators; they performed their work tasks at various stages in the grain processing process. Loaders worked in raw materials loading sections; grain cleaners, in areas where grain was cleaned; roller operators, in rolling sections; millers and grinders, in grinding sections; packers, in sections where flour was packed. All the examined workers gave their informative consent to take part in our research in full conformity with biomedical ethics requirements.

We detected diseases related to working conditions in full conformity with principles of evidence-based medicine; to do it, we detected how strong a cause-and-effect relation existed between health disorders and work in accordance with P 2.2.1766- $03^{4}$, calculated relative risk parameters (RR) and etiological fraction (EF) that belonged to a contribution made by occupational factors into pathology develop- ment. We applied 95\% confidence interval (CI) to assess validity of the obtained data.

Hygienic research results were statistically processed with Microsoft Office-2007 (MS Excel-07) software application and Statistica 10.0 software.

Results and discussion. A technological process applied for processing grain into flour includes a lot of stages, is rather complicated, power-operated and automated; it is a continuous process which should flow uninterruptedly. The basic stages of the process are consequent and interrelated; they include formation of grain into separate batches for further grinding (raw materials section); grain cleaning from admixtures and preparation for grinding (rolling section); grain grinding into flour and detection of flour grade (grinding section); flour packing into sacks (packing section). This technological process has its peculiarities; to be exact, it involves application of multiple equipment, including sealed one with aspiration of its interior volumes. The examined plants applied such equipment as air conveyors, mechanic transport (bucket conveyors and conveyor tracks) as well as gravity lines, to transport grain, intermediate grinding products, finished products, and production wastes. The equipment was handled, adjusted and controlled semi-automatically and automatically, and partially it involved remote control performed on computerized control desks.

The research results revealed that air contamination with organic dusts of raw materials, intermediate products, and finished products, was a leading adverse factor at contemporary flour-grinding production. Air dustiness was primarily caused by:

- inefficient work of dust removing systems;

- equipment that transports, cleans, or grinds grain and products made of it not being properly sealed;

- absence of tightness at junctions of grain and flour lines with bucket conveyors;

- equipment which can cause dustiness not being properly covered.

${ }^{4} \mathrm{P}$ 2.2.1766-03. Guide on occupational health risks assessment. Organizational and methodical grounds, assessment procedures and criteria [web-source] // KODEKS: an electronic fund of legal and reference documentation. - URL: http://docs.cntd.ru/document/901902053 (date of visit April 11, 2018). 
Table 1

Hygienic characteristics of occupational factors related to workplaces of workers employed at flour grinding production

\begin{tabular}{|l|c|c|c|c|c|}
\hline \multirow{2}{*}{ Occupational groups } & \multicolumn{5}{|c|}{ Occupational factors } \\
\cline { 2 - 6 } & $\begin{array}{c}\text { grain dust, } \\
\mathrm{mg} / \mathrm{m}^{3}\end{array}$ & $\begin{array}{c}\text { flour dust, } \\
\mathrm{mg} / \mathrm{m}^{3}\end{array}$ & $\begin{array}{c}\text { noise, equivalent } \\
\text { level of sound, } \\
\mathrm{dB}\end{array}$ & $\begin{array}{c}\text { average shifts } \\
\text { equivalent air } \\
\text { temperature, }{ }^{\circ} \mathrm{C} \\
\text { (cold season) }\end{array}$ & $\begin{array}{c}\text { average shiftr } \\
\text { equivalent air } \\
\text { temperature, }{ }^{\circ} \mathrm{C} \\
\text { (warm season) }\end{array}$ \\
\hline Grain cleaners & $11.29 \pm 2.4$ & - & $82 \pm 0.79$ & $11.9 \pm 1.7$ & $17.9 \pm 1.2$ \\
\hline Millers & $12.0 \pm 4.4$ & - & $83 \pm 0.91$ & $11.6 \pm 0.9$ & $18.9 \pm 1.9$ \\
\hline Roller operators & - & $16.5 \pm 4.1$ & $84 \pm 0.84$ & $12.4 \pm 0.78$ & $18.3 \pm 1.45$ \\
\hline Grinders & - & $9.7 \pm 2.1$ & $83 \pm 0.78$ & $12.4 \pm 1.05$ & $18.3 \pm 1.45$ \\
\hline Packers & - & $34.6 \pm 4.3$ & $78 \pm 0.67$ & $13.8 \pm 1.11$ & $18.5 \pm 1.4$ \\
\hline Loaders & $20.8 \pm 2.8$ & - & $78 \pm 1.56$ & $13.5 \pm 0.56$ & $17.2 \pm 0.9$ \\
\hline Permissible values & 4 & 6 & 80 & $14.0-22.0$ & $16.0-27.0$ \\
\hline
\end{tabular}

We examined the air in zones where workers employed at flour-grinding production had to breathe; our research was focused on dust contents in the air in these zones and it revealed that a type of dust and its quantitative contents depended on a particular stage in the technological process of grain processing (Table 1).

As we can see from the table, dustiness of working area air was higher than maximum permissible concentrations (MPC) at workplaces of workers from all the occupational groups existing at flour-grinding production.

We detected that grain dust which could be found in working area air at flour-grinding production mixed with free silicon dioxide $\left(\mathrm{SiO}_{2}\right)$, the fraction of which being from 10 to $40 \%$. This compound is the most adverse in terms of pathology emergence in the respiratory organs $[10,11]$. Depending on a section, grain dust consists of particles with their size up to $5 \mu \mathrm{m}$ and with their share varying from 59.0 to $87.6 \%$. Such particles have the greatest penetrability. Flour dust is organic, and 95\% of it are also particles with their size being up to $5 \mu \mathrm{m}$ in the analyzed air volume $(1000 \pm$ $\left.\pm 100 \mathrm{~cm}^{3}\right)$. According to data taken from literature, grain and flour dust can also contain pollen of various plants, microscopic fungi from such stems as Penicillium, Aspergillus, Fusarium, Tilletia etc., bacteria from such stems as Staphylococcu and Streptococcus; all these admixtures can cause allergic, fungi, or bacterial pathologies in workers' respiratory organs [5, 12-14]. Grain can also contain chemicals (formaldehyde) and pesticides after it has been treated and gassed [10].

In-plant noise generated by machinery, tools, transport equipment, and ventilation systems, is another adverse occupational factor which is specific for flour-grinding production and which can cause adverse effects on workers' health $[15,16]$. Noise that was registered in working zones at flour-grinding plants was constant and broadband; its levels depended on equipment. The highest noise levels $(104.0 \pm 0.72 \mathrm{~dB})$ that exceeded maximum permissible one and could be heard within the overall audible range, excluding $63 \mathrm{~Hz}$ frequency, were registered at workplaces of workers in the roller section near rolling machinery. Noise levels produced by compressor units which were used as drivers for air conveyors moving products inside a workshop reached $101.8 \pm 0.48 \mathrm{~dB}$; they exceeded maximum permissible levels at frequencies equal to $63-8,000$ Hz. Noise levels which occurred in grain cleaning workshops near separators and cleaning machinery ranged within $87-95 \mathrm{~dB}$, exceeding maximum permissible levels at frequencies equal to $250-8,000 \mathrm{~Hz}$. Noise levels detected in soundproof control cabins didn't exceed maximum permissible levels ( $80 \mathrm{~dB})$. Equivalent noise levels calculated for an overall work shift were not more $5 \mathrm{~dB}$ higher than maximum permissible levels taking into account overall time which workers spent in zones where the equipment was 
maintained. So, such conditions could be ranked as adverse ones with the 1st hazard category, class 3.1 (table 1). We also registered vibration in grinding sections but its adjusted level didn't exceed maximum permissible one (class 2).

A cooling microclimate usually occurred in working zones of flour-grinding plants during a cold season. The lowest air temperatures in working zones were detected at upper floors of grain cleaning sections. The temperature there went down to $8^{\circ} \mathrm{C}$ which was $7^{\circ} \mathrm{C}$ lower that permissible levels for working conditions (IIa) fixed for operators at flour-grinding productions. But at the same time, average shift equivalent air temperature amounted to $11.9^{\circ} \mathrm{C}$ $-13.8 \pm 1.11$ taking into account overall time which workers had to spend in workshops with cooling microclimate inside them; such working conditions were estimated as having the $1 \mathrm{st}$ hazard category (class 3.1).

Air speed was higher than the standard in all seasons and in all the workshops (up to $1.4-1.6 \mathrm{~m} / \mathrm{sec}$ against $0.2-0.4 \mathrm{~m} / \mathrm{sec}$ ). It could make effects caused by low air temperatures even worse and cause peripheral neurovascular disorders, hypertension, respiratory diseases and diseases in the peripheral nervous system [17].

Labor hardness for workers employed at flour-grinding plants was determined by peculiarities of working tasks performed by various occupational groups. Grain cleaners, millers, roller operators, and grinders handled control and measuring instruments and dealt with maintenance of various equipment installed at different floors. Therefore, they had to constantly moved from one place to another covering a distance of more than $8 \mathrm{~km}$ horizontally and up to $2.5 \mathrm{~km}$ vertically. They also had to eliminate jams which occurred when grain and products of its processing moved through gravity lines; they had to do it in forced working postures and overall time spent by them in such postures amounted to $7-10 \%$ of their overall shift. The total time spent in an uncomfortable posture didn't exceed $25 \%$ of a shift; a number of forced body bendings which exceeded $30^{\circ}$ was from 100 to 300 per a shift. Packers who packed flour into sacks, sewed sacks up, and cleaned their workplaces, had to work in a fixed uncomfortable working posture from time to time (up to $25 \%$ of a shift). Labor of loaders employed at warehouses where raw materials and finished products were stored involved manual and partially mechanical lifting and moving of cargoes with weight exceeding $35 \mathrm{~kg}$ (3.2 hazard class). A number of forced body bendings exceeding $30^{\circ}$ was from 51 to 100 per a shift ( 2 class). Overall assessment of working conditions as per labor hardness corresponded to hard 3.2 hazard class labor for loaders, grain cleaners, and packers; hard 3.1 hazard class labor, for millers, roller operators, and grinders. Hard labor is known to cause functional overstrain of workers' bodies and it can lead to occupational diseases in the peripheral nervous system and the musculoskeletal apparatus $[18,19]$.

Labor intensity for workers at all the stages in the technological process existing at flour-grinding production (loaders excluded) involved total operational loads (up to $75 \%$ of a shift), high sensory loads and loads on their hearing apparatus that resulted from increased noise levels. Work was organized in 3 day shifts and 1 night one; each shift was 12 hours long. Labor intensity for workers from all the occupational groups was assessed as being permissible (average hazard degree, class 2).

The total assessment of working conditions for workers employed at flour-grinding production which took into account the overall set of occupational factors and labor process factors allows to rank them as hazardous, having 2 and 3 hazard category (3.2 and 3.3 classes) depending on a type of work performed (table 2).

We assessed occupational risks basing on the results of quantitative assessment of exposure to occupational factors (as per working conditions classes) in conformity with the criteria set forth in the Guide $\mathrm{P} 2.2 .1766-03^{4}$. This assessment was based on determination of expected occupational risk category. We detected that a priori risk for the health of flourgrinding production operators caused by exposure to adverse occupational factors varied from average (substantial) to high (intolerable) depending on a stage in the technological process. 
Table 2

Hygienic assessment of working conditions and occupational health risks for workers employed at various stages of the technological process existing at flour-grinding production

\begin{tabular}{|c|c|c|c|c|c|c|c|}
\hline \multirow[b]{2}{*}{ Occupational groups } & \multicolumn{5}{|c|}{ Factors related to working conditions } & \multirow[b]{2}{*}{$\begin{array}{l}\text { Overall } \\
\text { estimate }\end{array}$} & \multirow[b]{2}{*}{$\begin{array}{l}\text { Occupational } \\
\text { risk category }\end{array}$} \\
\hline & APFE & $\begin{array}{l}\text { micro- } \\
\text { climate }\end{array}$ & noise & $\begin{array}{c}\text { labor } \\
\text { hardness }\end{array}$ & $\begin{array}{l}\text { labor } \\
\text { intensity }\end{array}$ & & \\
\hline Grain cleaners & 3.1 & 3.1 & 3.1 & 3.2 & 2 & 3.2 & \multirow{5}{*}{$\begin{array}{c}\text { Average } \\
\text { (substantial) } \\
\text { risk }\end{array}$} \\
\hline Millers & 3.1 & 3.1 & 3.1 & 3.1 & 2 & 3.2 & \\
\hline Roller operators & 3.1 & 3.1 & 3.1 & 3.1 & 2 & 3.2 & \\
\hline Grinders & 3.1 & 3.1 & 3.1 & 3.1 & 2 & 3.2 & \\
\hline Packers & 3.1 & 3.1 & 2 & 3.2 & 2 & 3.2 & \\
\hline Raw materials loaders & 3.2 & 3.1 & 2 & 3.2 & 2 & 3.3 & $\begin{array}{c}\text { High } \\
\text { (intolerable) risk }\end{array}$ \\
\hline
\end{tabular}

Note: APFE means aerosols with primarily fibrogenic effects

To estimate effects exerted by working conditions on workers' health as per results obtained in the course of periodical medical examinations, we calculated relative risk (RR) and etiological fractions (EF) of contribution made by occupational factors into diseases emergence. As a result we revealed an average cause-and-effect relation between respiratory organs diseases and work $(\mathrm{RR}=1.64 ; \mathrm{EF}=39 \%$, $\mathrm{CI}=0.5-4.5)$; that means that such diseases are occupational ones.

The performed research gave grounds for determining priority measures aimed at reduction of occupational risks for health of workers employed at flour-grinding production. First of all, such measures should include advanced development of both technology and equipment. Unfortunately, dustiness in working zones cannot be eliminated completely at contemporary flour-grinding production; therefore, it is especially important to implement technical, sanitary-hygienic, and medical-preventive activities at such plants. Here we can primarily mention the following: maximum possible automation and sealing of equipment, control over dustiness in working zones, strict adherence to scheduled dates of equipment maintenance and overhaul, and implementation of more rational work and leisure regimes (time-based protection). Timely peri- odical medical examinations, preventive and rehabilitation activities also play very important part in the process.

Our research allowed us to come to the following conclusions:

1. Workers employed at flour-grinding production are exposed to a set of adverse occupational factors at their work places; these factors create hazardous working conditions of the 2nd and 3rd hazard category (classes 3.2 and 3.3).

2. Occupational health risks for workers are estimated to be either average (substantial) or high (intolerable) depending on work tasks performed by workers.

3 . There is an authentic average causeand-effect relation between respiratory organs diseases and work; that means such diseases are occupational.

When any managerial decisions are made on minimization of occupational health risks for workers employed at flour-grinding production, the most important thing is to prevent negative effects exerted by dustiness in working zones.

Funding. The research was not granted any sponsor support.

Conflict of interests. The authors state there is no any conflict of interests. 


\section{References}

1. Gosudarstvennaya programma razvitiya sel'skogo hozyaistva i regulirovaniya rynkov sel'skohozyaistvennoi produktsii, syr'ya i prodovol'stviya na 2013-2020 gody: postanovlenie Pravitel'stva ot 14 iyulya 2012 goda №717. [The state program of development of agriculture and regulation of the agricultural production's markets, raw materials and food for 2013-2020: Resolution of the government of July 14, 2012 No. 717]. Available at: https://www.ruspitomniki.ru (18.02.2018) (in Russian).

2. Maremukov T.A. Issledovanie problem razvitiya zernovykh i zernopererabatyvayushchikh predpriyatii [Research on issues related to development of grain and grain-processing productions]. Ekonomicheskii vestnik Rostovskogo gosudarstvennogo universiteta, 2009, vol. 7, no. 4-3, pp. 112-115 (in Russian).

3. Shilov V.N. Sanitarno-gigienicheskie usloviya truda na predpriyatiyakh mukomol'noi promyshlennosti [Sanitary and hygienic working conditions at the enterprises of the flour-grinding industry]. Aktual'nye voprosy gigieny v sel'skokhozyaistvennom proizvodstve: mezhvuzovskii nauchnyi sbornik. Saratov, Saratovskii universitet Publ., 1987, pp. 74-79 (in Russian).

4. Dadiani K.P. [et al.]. Gigienicheskaya kharakteristika proizvodstvennoi sredy mukomol'nykh predpriyatii [Hygienic characteristics of the production environment of the flour-grinding enterprises]. Gigiena i sanitariya, 1992, no. 11, pp. 45-49 (in Russian).

5. Grushko A.B., Latyshevskaya N.I. Sostoyanie vozdushnoi sredy na rabochikh mestakh na predpriyatiyakh mukomol'noi promyshlennosti [Working area air at flour-grinding enterprises]. Problemy okhrany proizvodstvennoi i okruzhayushchei sredy: materialy mezhdunarodnoi nauchno-tekhnicheskoi konferentsii. Volgograd, 1997, 27 p. (in Russian).

6. Nemova I.S. Vliyanie neblagopriyatnykh faktorov proizvodstva na sostoyanie zdorov'ya rabochikh mukomol'nogo zavoda goroda Ul'yanovska [The influence of unfavourable industrial factors on the health condition mealing manufacture workers Ulyanovsk-town]. Sovremennye naukoemkie tekhnologii, 2005, no. 2, pp. 78-79 (in Russian).

7. Gromova B.C. K gigienicheskoi kharakteristike zernovoi pyli [On hygienic characteristics of grain dust]. Gigiena truda i profzabolevaniya, 1985, no. 3, 33 p. (in Russian).

8. Sokolova L., Fedorova M., Macievich L., Nefedova M., Masaeva L. Pleurisies in pulmonology department: of City Clinical Hospital in Moscow. European Respiratory Journal, 2006, vol. 28, pp. 29-57.

9. Becklake M.R. Grain dust and health: Occupational pulmonary disease in grain workers: focus on grain dust and health. In: J. Dosman, D. Cotton, eds. New York, Academic Press Publ., 1980, pp. 189-200.

10. Fournier E., Tonnel A.B., Gosset P. [et al.]. Early neutrophil alveolitis after antigen inhalation in hypersensitivity pneumonitis. Chest, 1985, vol. 88, pp. 563-566.

11. Vasil'eva O.S. Spirin V.F., Velichkovskii B.T. Zabolevaniya organov dykhaniya ot organicheskoi pyli u rabotnikov sel'skogo khozyaistva [Respiratory organs diseases caused by organic dust in workers employed in agriculture]. Professional'nye zabolevaniya organov dykhaniya: natsional'noe rukovodstvo [Occupational respiratory organs diseases: national guide]. In: N.F. Izmerov, A.G. Chuchalin, eds. Moscow, GEOTAR-Media Publ., 2015, pp. 560-574 (in Russian).

12. Professional'naya patologiya. Natsional'noe rukovodstvo [Occupational pathology: national guide]. In: N.F. Izmerov, ed. Moscow, GEOTAR-Media Publ., 2011, 777 p. (in Russian).

13. Seidov I.M. [et al.]. K voprosu o zagryaznenii okruzhayushchei sredy mukomol'nogo i kombikormovogo zavodov mikroorganizmami bakterial'noi i gribkovoi prirody [On environmental contamination with bacteria and fungi at flour-grinding productions and combine fodder factories]. Materialy $V$ $s^{\prime \prime}$ ezda epidemiologov i parazitologov Azerbaidzhana, Baku, 1980, pp. 87-89 (in Russian).

14. Shevlyakov V.V., Ushkov S. A, Filonov V.P. Osobennosti biologicheskogo deistviya i gigienicheskoi reglamentatsii $\mathrm{v}$ vozdukhe rabochei zony muchnoi pyli [Peculiarities of biological effects exerted by flour dust and hygienic standardization of its contents in working area air]. Respublikanskii institut vysshei shkoly, Minsk, 2010, 160 p. (in Russian).

15. Blainey A.D., Topping M.D., Oilier S., Davies R.J. Respiratory symptoms in arable farmworkers: role of storage mites. Thorax, 1988, vol. 43, pp. 697-702.

16. May J. Occupational hearing loss. American Journal of Industrial Medicine, 2000, vol. 37, no. 1, $112 \mathrm{p}$. 
17. Denisov E.I., Il'kaeva E.N. Shum i risk poteri slukha [Noise and risk of hearing loss]. Professional'nyi risk dlya zdorov'ya rabotnikov (rukovodstvo) [Occupational health risk for workers (guidelines)]. In: N.F. Izmerov, E.I. Denisov, eds. Moscow, Trovant Publ., 2003, pp. 114-124 (in Russian).

18. Afanas'eva R.F., Burmistrova O.V. Okhlazhdayushchaya sreda i ee vliyanie na organizm [Cooling environment and its effects on a body]. Professional'nyi risk dlya zdorov'ya rabotnikov (rukovodstvo) [Occupational health risk for workers (guidelines)]. In: N.F. Izmerov, E.I. Denisov, eds. Moscow, Trovant Publ., 2003, pp. 142-149 (in Russian).

19. Danilov A.N., Bezrukova G.A., Novikova T.A. Tyazhest' trudovogo protsessa kak determinanta professional'nogo riska zdorov'yu rabotnikov sel'skogo khozyaistva [Work hardiness as a determinant of occupational health risk in agricultural workers]. Meditsina truda i promyshlennaya ekologiya, 2017, no. 9 , pp. 59 (in Russian).

20. Jin K., Sorock G.S., Courtney T., Liang Y., Yao Z., Matz S., Ge L. Risk factors for work-related low back pain in the People's Republic of China. International Journal of Occupational and Environmental Health, 2000, vol. 6, no. 1, pp. 26-33.

Novikova T.A., Aleshina Yu.A., Danilov A.N., Spirin V.F. Contemporary working conditions and assessment of occupational health risk for workers employed at flour-grinding productions. Health Risk Analysis, 2019, no. 1, pp. 50-57. DOI: 10.21668/health.risk/2019.1.05.eng

Received: 31.08 .2018

Accepted: 11.11 .2019

Published: 30.03.2019 
UDC 616-008.9:612.392.64-022.252-08(476)

DOI: $10.21668 /$ health.risk/2019.1.06.eng

Read

online

\title{
RISK COMMUNICATION AS A COMPONENT THAT PROVIDES STABILITY OF STRATEGY AIMED AT ELIMINATING DISEASES CAUSED BY IODINE DEFICIENCY IN BELARUS
}

\author{
E.V. Phedorenko ${ }^{1}$, N.D. Kolomiets ${ }^{2}$, T.V. Mokhort ${ }^{3}$, A.N. Volchenko ${ }^{1}$, \\ E.G. Mokhort ${ }^{3}$, S.V. Petrenko ${ }^{4}$, S.I. Sychik ${ }^{1}$ \\ ${ }^{1}$ Scientific-Practical Hygiene Center, 8 Akademicheskaya Str., Minsk, 220012, Belarus \\ ${ }^{2}$ Belarus Medical Academy for Post-graduate Studies, 3/3 P. Brovki Str., Minsk, 220013, Belarus \\ ${ }^{3}$ Belorusskiy State Medical University, 83 Dzerzhinskiy av., Minsk, 220116, Belarus \\ ${ }^{4}$ A.D. Sakharov's International State Ecological Institute, 23/1 Dolgobrodskaya Str., Minsk, 220070, Belarus
}

There is a strategy being implemented now in Belarus that involves obligatory application of high quality iodized salt in food industry; it has resulted in iodine deficiency elimination among population. Sales of iodized salt account for more than $70 \%$ of the overall salt sales in retail outlets. However, attention paid to the issue has started to decline recently, including mass media; at present there is no social advertising that informs people about iodized salt being useful for their health. Our research object was population awareness about various aspects related to prevention of diseases caused by iodine deficiency and objective indicators of iodine provision. Our research goal was to determine probable risks of iodine deficiency prophylaxis becoming less efficient and to substantiate ways how to prevent negative trends.

Data and methods. We assessed population awareness on iodine deficiency via questioning; overall, 805 people living in Belarus took part in it. Alimentary exposure to iodine was calculated for various scenarios taking into account natural iodine contents and artificially added iodine in food products as well as consumption volumes. Ioduria was assessed with cerium-arsenite technique. We considered dynamics in morbidity with simple goiter and congenital hypothyroidism to be indicators of iodine provision. Basic results. We detected that most respondents, $658(81.7 \%$, $95 \%$ CI 78.8-84.7) to be exact, thoughts that their therapists were the primary source of knowledge on health-related issues; $176(21.9 \%, 95 \%$ CI 15.8-28.0) trusted mass media including the Internet. More than half respondents $(61.4 \%, 95 \%$ CI 60.8-62.0\%) and medical personnel statistically significantly more frequently $(77.1 \%, 95 \%$ CI $70.7-83.61 \%)$ believed there was a iodine deficiency problem existing in the country.

We didn't detect any risk of excessive iodine introduction with food products. Selective monitoring over ioduria among children proves their iodine provision is quite appropriate as it amounts to more than $100 \mu \mathrm{g} / \mathrm{l}$. Dynamics of primary morbidity with congenital hypothyroidism confirms that stable positive results have been achieved in the sphere; in 2006 primary morbidity was equal to 1.96 per 100 thousand people, but in 2017 it dropped to 0.96 per 100 thousand people. It proves that Belarus is among countries where population consume proper amounts of iodine. But an arising trend for lower awareness about iodine deficiency calls for more active risk communication about possible diseases related to iodine deficiency, including mass media campaigns.

Key words: iodine, iodized salt, monitoring, diseases caused by iodine deficiency, risk communication.

(C) Phedorenko E.V., Kolomiets N.D., Mokhort T.V., Volchenko A.N., Mokhort E.G., Petrenko S.V., Sychik S.I., 2019

Ekaterina V. Phedorenko - Candidate of Medical Sciences, Associate Professor, Deputy Director responsible for support of practical sanitary-epidemiologic surveillance and work with the Eurasian Economic Commission (e-mail: afedorenko71@mail.ru; tel. +375 172-84-13-65; ORCID: http://orcid.org/0000-0003-1240-1234).

Natalia D. Kolomiets - Doctor of Medical Sciences, Professor, Head of the Department for Epidemiology and Microbiology (e-mail: ndkolomiets@mail.ru; tel. +375 293-54-39-04; ORCID:http://orcid.org/0000-0002-4837-5181).

Tatyana V. Mokhort - Doctor of Medical Sciences, Professor, Head of the Endocrinology Department (e-mail: tat_mokh@mail.ru; tel. +375 296-36-52-82; ORCID: http://orcid.org/0000-0002-5040-3460).

Alina N. Volchenko - Candidate of Medical Sciences, Associate Professor at the Department for Epidemiology and Microbiology (e-mail: libertatta@gmail.com; tel. +375 447-73-33-83; ORCID: https://orcid.org/0000-0002-0133-0904).

Elena G. Mokhort - Candidate of Medical Sciences, Associate Professor at the Endocrinology Department (e-mail: al_mokhort@mail.ru; tel. +375 296-78-87-72; ORCID: http://orcid.org/0000-0002-6748-9598).

Sergey V. Petrenko - Candidate of Medical Sciences, Associate Professor, Head of the Research Laboratory for Anthropoecology and Public Health (e-mail: petrenko51@yahoo.com; tel. +375 256-12-14-10; ORCID: http://orcid.org/0000-0001-6248-4619).

Sergey I. Sychik - Candidate of Medical Sciences, Associate Professor, Head of the Scientific-Practical Hygiene Center (e-mail: respch@rspch.by; tel. +375 172-84-13-70; ORCID: http://orcid.org/0000-0002-5493-9799). 
Introduction. Iodine is an essential element with great biological significance. If it isn't naturally introduced in a body in sufficient quantities, it results in certain iodine deficiency disorders (IDD), such as thyroid gland diseases, miscarriages, greater perinatal mortality and risk of physical and mental retardation among children, and endemic cretinism. Incidence in this case is correlated to quantitative distribution of iodine in the environment in a specific region [1]. According to WHO data, about $1 / 3$ of the overall world population suffer from insufficient introduction of iodine and it causes serious threats for public health. In spite of serious outcomes IDD might have they can be quite successfully prevented, and there are not so many social and medical problems that can be solved such easily [2, 3]. Global efforts made by the world society have substantially changed geography of IDD prevalence; use of iodized salt in households has been recognized as a basic way to fight the above-mentioned morbid state. In relation to that, many countries have changed their national legislation related to regulation of population nutrition. However, such a radical way hasn't been eventually supported by all the countries in the world, either due to moral and ethical reasons (freedom of choice), or economic and political ones $[4,5]$.

Iodine alimentary insufficiency is vital for Belarus as well and it is confirmed by historically known regions in the country that are endemic as per goiter; the situation is caused by geochemical iodine deficiency in soils (within $0.1-9.23 \mathrm{mg} / \mathrm{kg}$ ) and drinking water $\left(1.9-3.2 \mu \mathrm{g} / \mathrm{dm}^{3}\right)$. As the country is located far from any sea, population traditionally tend to consume low quantities of sea fish and sea food that could naturally eliminate any iodine deficiency [6]. Research that was accomplished at the end of the last century, including that supported by WHO/UNICEF, revealed that ioduria median amounted to $44.5 \mu \mathrm{g} / 1$, and endemic goiter prevalence among children reached $28.0-30.0 \%$. These data again indicated it was necessary to investigate iodine deficiency in the country and to work out and implement some actions in this respect. In 2000 the Belarus Public Healthcare Ministry started to work out and implement an unique national strategy aimed at eliminating iodine deficiency; it was based on the following principles:

- making alterations into The State Standards issued in Belarus that fixed the requirements to iodine concentration in iodized salt as being equal to $40 \pm 15 \mathrm{mg} / \mathrm{kg}$;

- applying potassium iodate instead of potassium iodide to iodize salt as it allowed to substantially improve iodine preservation and culinary properties of food;

- obligatory application of iodized salt in food products manufacturing and in catering, including nutrition arranged for children and adults in pre-school facilities, schools, and various establishments;

- information campaigns for population at all levels;

- medical and social-hygienic monitoring.

Iodine Global Network has created certain efficiency indicators that are usually applied to assess national programs; they include median for iodine excretion with urine that should excess $100 \mu \mathrm{g} / \mathrm{l}$ in schoolchildren and pregnant women at a national and/or subnational level, or assessment of a share that belongs to qualitative iodized salt on the consumer market and in industry. In 2013 these indicators were analyzed as regards the prevention program in Belarus, and the results allowed experts to recommend the International Council for Control of Iodine Deficiency Disorders (ICCIDD) to assign Belarus into a group of countries with adequate iodine provision [7]. Elimination of iodine deficiency in nutrition doesn't lead to immediate IDD elimination as it usually takes several years of persistent efforts to detect a decrease in endemic goiter prevalence among population who were born and have been permanently living in a specific biogeochemical province. However, if activities are controlled sporadically or there is no control at all, it results in poorer iodine provision and a growth in incidence with IDD. Therefore, to assess efficiency and to support stability of an IDD prevention program, international expert organizations recommend to perform regular 
monitoring over implemented activities as per all the necessary components $[8,9,10]$.

Given all the above-mentioned, we chose a research goal that was to determine possible risks of a decrease in IDD prophylaxis efficiency and to substantiate ways which were necessary to prevent any negative trends in the sphere.

We solved the following tasks:

- performed a complex examination of people awareness about iodine deficiency and their attitudes towards iodized salt consumption;

- calculated alimentary exposure to iodine taking into account different ways of its introduction into a body;

- assessed iodine provision as per ioduria monitoring, dynamics of morbidity with simple goiter and primary congenital hypothyroidism.

Data and methods. To assess awareness people had about IDD and their attitudes towards that issue, we took a questionnaire recommended by WHO (with certain supplements) for epidemiologic research applied in Belarus since 1997. Overall, we questioned 805 people living in Belarus, in Minsk and other regions. To assess alimentary exposure to iodine, we calculated its introduction taking into account both background concentrations and iodized products; we applied frequency analysis to estimate consumption of food products with natural iodine contents, food products manufactured with iodized salt, and consumption of food products enriched with iodine as well.

We determined iodine excretion with urine with spectrophotometric cerium-arsenite technique accepted by WHO as a conventional international method [11].

Accomplished research allowed us to create a computer database in EXCEL - XP. The obtained data were statistically processed with STATISTICA 6.0 applied software. The questioning results are given as $\%$ with $95 \%$ confidence interval $(95 \% \mathrm{CI})$. Research on incidence with simple goiter and primary congeni- tal hypothyroidism was performed on the basis of data taken from the state statistical reports ${ }^{1}$.

Results. Nowadays people can quite easily get an access to any information on how to preserve their health, healthy lifestyle, rational nutrition, or certain products that should be included into their daily ration. However, if people don't have any specialized training or education, it is sometimes rather difficult for them to figure these issues out on their own and to come to a correct opinion; and it is even harder to adhere to relevant principles.

We naturally assumed that medical workers should be better aware how to preserve health than respondents with any other occupation. For this reason, when analyzing the questioning results, we created two groups; the first one consisted of 594 people without medical education who didn't work at any healthcare organization, and the second one included 210 people with medical or biological education and an occupation related to providing medical aid (medical or healthcare workers).

The results revealed that most respondents thought their attending medical doctors to be the basic source of information on how to preserve health as such an answer was given by 658 people $(81.7 \%, 95 \%$ CI $78.8-84.7)$, and the share of positive responses didn't differ significantly in groups 1 and 2 and amounted to $83.9 \%(95 \% \mathrm{CI} 80.6-87.1)$ and $75.7 \%(95 \%$ CI 69.0-82.4) respectively. Other important sources of information included the Internet, 176 people $(21.9 \%, 95 \%$ CI $15.8-28.0)$; printed editions, 118 people $(14.7 \%, 95 \%$ CI $8.3-21.0)$; TV, 80 people $(9.9 \%, 95 \%$ CI $3.4-16.5 \%)$. The least trust was put by our respondents into relatives, friends, and other sources of information, from $1.5 \%$ to $7.0 \%$ (95\% CI $0.0-13.6 \%)$. There was a question who bore the greatest responsibility for prevention of non-infectious diseases, including cardiovascular system diseases and endocrine system diseases; most respondents inclined to think the responsibility was utterly their own as 678 people $(84.2 \%$,

\footnotetext{
1 "The Report on number of diseases registered in patients aged 18 and older, living on a territory on which medical; services are rendered by a healthcare organization in 20 _ ", approved by the Order by Belarus National Statistical Committee on October 08, 2012 No. 168, with amendments made on August 11, 2017 No. 90.[web-source]. - URL: http://www. belcmt.by/ru/activity-of-the-center/statistika/state-statistical-reporting (date of visit November 12, 2018).
} 
95\% CI 81.5-87.0) gave this answer. There were other popular answers, for example, "medical staff should do it", 196 people $(24.4 \%$, 95\% CI 18.3-30.4), or "the state", 130 people $(16.2 \%$, 95\% CI 9.8-22.5\%). A rather small number of respondents, 30 people $(3.7 \%, 95 \%$ CI $0.0-10.6)$ thought that "local authorities" should take care of their health, and only 8 people $(1.0 \pm 0.3 \%)$ $(1.0 \%, 95 \%$ CI $0.0-8.3 \%)$ stated that the above-mentioned diseases "couldn't be prevented". We didn't reveal any significant discrepancies between answers given by people from two different groups. In spite of quite a big number of respondents - 84.2\% (95\% CI $81.5-87.0 \%$ ) - thinking that taking care of their health was their own responsibility, only 258 of them $(32.1 \%, 95 \%$ CI $26.4-37.7 \%)$ controlled their blood pressure regularly and on their own, without any doctor's recommendations. 287 respondents $(35.7 \%$, 95\% CI 30.1-41.2\%) showed interest in this health parameter when they visited a doctor; 260 respondents $(32.3 \%$, 95\% CI 26.6-38.0) didn't controlled it. Only one fourth of 258 people $(24.4 \%, 95 \%$ CI $13.8-35.0 \%$ ) who controlled their blood pressure were medical workers. Therefore, correct "theoretical" understanding that it is necessary to take care of one's health wasn't put into practice even regarding a simplest issue, control over blood pressure, and the situation was the same either for medical workers or people with any other occupation.

Table 1 contains the results regarding awareness that respondents have about iodine deficiency. 156 people of the overall sampling (19.4\%, 95\% CI 13.2-25.6\%) stated that they or their relatives who lived with them had thyroid gland diseases, 111 people in group 1 $(13.8 \%, 95 \%$ CI $7.4-20.2 \%)$, and 45 people (5.6\%, 95\% CI $0.0-12.3 \%)$ in group 2. More than a half respondents thought that there was a problem related to iodine deficiency in our country as 494 people gave such an answer (61.4\%, 95\% CI 60.8-62.0\%), and here statistically significantly greater share of medical workers were of this opinion, $162(77.1 \%$, $95 \%$ CI $70.7-83.6 \%$ ) in group 2 against 332 (55.8\%, 95\% CI 50.5-61.1\%) against group 1 . We should note that according to a national questioning accomplished in $2003,74 \%$ out of 5,000 respondents knew there was a iodine deficiency in Belarus, and $87 \%$ saw advertising on TV that was urging them to consume iodized salt [12]. It proves that awareness on IDD issues among population has decreased. And, taking into account priority sources of information mentioned by our respondents, we should assume that TV advertising won't have any substantial influence on consumers awareness on necessity to prevent alimentary iodine deficiency.

There was a question whether a person could control iodine consumption on his or her own making it sufficient; 495 respondents (61.5\%, 95\% CI 60.9-62.1) answered "yes", and these answers were quite in line with those given to the previous question in both groups. Eventually, 159 medical workers $(75.7 \%, 95 \%$ CI 69.0-82.4) were statistically significantly more self-confident than 336 people who didn't work at a medical organization $(56.5 \%$, 95\% CI 51.2-61.7\%). There was statistically significantly smaller number of medical workers who had difficulty answering this question, (8.1\%, 95\% CI $0.0-21.5 \%)$, than people who didn't work at any medical organization (27.7\%, 95\% CI 20.9-34.6). And quite similar number of people in both groups believed they couldn't solve this problem themselves (15.8\%, 95\% CI 8.4-23.2 and 16.2\%, 95\% CI $3.8-28.6 \%$, respectively).

More than half respondents (440 people or $55 \%, 95 \%$ CI 54.1-55.3) stated it was impossible to eliminate iodine deficiency by consuming only "local" products; however, statistically significantly more medical workers knew it (164 people or $78 \%, 95 \%$ CI $71.8-84.4$ ).

Medical workers were naturally better aware of health disorders caused by iodine deficiency and its insufficient introduction into a body (such as lower intelligence, endemic goiter, or chronic fatigue) than people in group 1 or the overall sampling (Table 1). However, only $28 \%$ of medical workers $(95 \%$ CI 16.1-39.1) and $16 \%$ of other respondents (95\% CI 8.4-23.4) stated that iodine deficiency could be an obstacle for pregnancy (as it causes infertility); so, as we can see, only 
Table 1

Assessment of awareness on iodine deficiency among people living in Belarus

\begin{tabular}{|c|c|c|c|c|c|c|c|c|c|}
\hline \multirow{2}{*}{$\begin{array}{l}\text { Question / } \\
\text { Answer to it }\end{array}$} & \multicolumn{3}{|c|}{ Total } & \multicolumn{3}{|c|}{ Not related to medicine } & \multicolumn{3}{|c|}{ Medical workers } \\
\hline & abs. & $\%$ & $\mathrm{CI}$ & abs. & $\%$ & $\mathrm{CI}$ & abs. & $\%$ & $\mathrm{CI}$ \\
\hline \multicolumn{10}{|c|}{ Do you / you relatives who live with you have any thyroid gland diseases? } \\
\hline Yes & 156 & 19 & $13.2-25.6$ & 111 & 19 & $11.4-25.9$ & 45 & 21 & $9.4-33.4$ \\
\hline No & 649 & 81 & $77.6-83.6$ & 484 & 81 & $77.9-84.8$ & 165 & 79 & $72.3-84.8$ \\
\hline \multicolumn{10}{|c|}{ Do you think there is iodine deficiency in Belarus? } \\
\hline Yes & 494 & 61 & $60.8-62.0^{* *}$ & 332 & 56 & $50.5-61.1^{*}$ & 162 & 77 & $70.7-83.6^{*}$ \\
\hline No & 87 & 11 & $4.3-17.3$ & 66 & 11 & $3.5-18.7$ & 21 & 10 & $0.0-23.1$ \\
\hline Difficult to say & 224 & 28 & $21.9-33.7$ & 197 & 33 & $26.5-39.7^{*}$ & 27 & 13 & $0.0-25.7^{*}$ \\
\hline \multicolumn{10}{|c|}{ Can people see to sufficient consumption of iodine themselves? } \\
\hline Yes & 495 & 62 & $60.9-62.1^{* *}$ & 336 & 56 & $51.2-61.8^{*}$ & 159 & 76 & $69.0-82.4^{*}$ \\
\hline No & 128 & 16 & $9.56-22.2$ & 94 & 16 & 8.4-23.2 & 34 & 16 & $3.8-28.6$ \\
\hline Difficult to say & 182 & 22 & $16.5-28.7$ & 165 & 28 & $20.9-34.6$ & 17 & 8 & $0.0-21.5$ \\
\hline \multicolumn{10}{|c|}{$\begin{array}{c}\text { Do you know that if you consume only local food (grown and manufactured in Belarus) } \\
\text { it will not provide you with essential quantity of iodine? }\end{array}$} \\
\hline Yes & 440 & 55 & $54.1-55.3^{* *}$ & 276 & 46 & $40.5-52.3^{*}$ & 164 & 78 & $71.8-84.4^{*}$ \\
\hline No & 348 & 43 & $42.6-43.9^{* *}$ & 304 & 51 & $45.3-56.7^{*}$ & 44 & 21 & \begin{tabular}{|l}
$8.9-33.0^{*}$ \\
\end{tabular} \\
\hline Difficult to say & 18 & 2 & $0.0-9.3$ & 16 & 3 & $0.0-10.9$ & 2 & 1 & $0.0-20.0$ \\
\hline \multicolumn{10}{|c|}{ What health disorders are caused by iodine deficiency? } \\
\hline Excess weight & 198 & 25 & $18.6-30.6$ & 151 & 25 & $18.4-32.3$ & 47 & 23 & $10.5-34.3$ \\
\hline Lower intelligence & 280 & 35 & $29.2-40.4^{* *}$ & 162 & 27 & $20.4-34.4^{*}$ & 118 & 56 & $42.2-65.1^{*}$ \\
\hline Growth retardation & 248 & 31 & $25.1-36.6$ & 157 & 26 & $19.5-33.3$ & 91 & 43 & $33.2-53.5$ \\
\hline Infertility & 152 & 19 & $12.7-25.1$ & 94 & 16 & $8.4-23.4$ & 58 & 28 & \begin{tabular}{|l|}
$16.1-39.1$ \\
\end{tabular} \\
\hline Endemic goiter & 571 & 71 & $67.2-74.7^{* *}$ & 384 & 65 & $59.8-69.3^{*}$ & 187 & 89 & $84.6-93.5^{*}$ \\
\hline Chronic fatigue & 457 & 57 & $56.2-57.4^{* *}$ & 313 & 53 & $47.1-58.1^{*}$ & 144 & 69 & 61.0-76.2* \\
\hline Other & 15 & 2 & $0.0-8.9$ & 10 & 2 & $0.0-10.1$ & 5 & 2 & $0.0-17.3$ \\
\hline Difficult to say & 42 & 5 & $0.0-12.0$ & 41 & 7 & $0.0-14.0$ & 1 & 0.5 & $0.0-14.0$ \\
\hline \multicolumn{10}{|c|}{ Do pregnant and breast-feeding women need to consume iodine in greater quantities? } \\
\hline Yes & 505 & 63 & $62.2-63.3^{* *}$ & 345 & 58 & $52.8-63.2^{*}$ & 160 & 76 & $69.6-82.8^{*}$ \\
\hline No & 42 & 5 & $0.0-12.0$ & 26 & 4 & $0.0-12.4$ & 16 & 8 & $0.0-21.1$ \\
\hline Difficult to say & 258 & 32 & $26.4-37.7$ & 224 & 38 & $31.3-44.0^{*}$ & 34 & 16 & $3.8-28.6^{*}$ \\
\hline
\end{tabular}

Note: * means discrepancies between groups 1 and 2 are statistically significant, $p \leq 0.05$;

** means discrepancies in a number of answers given by overall sampling are statistically significant in comparison with a number of answers given by medical workers, $\mathrm{p} \leq 0.05$.

152 people in the overall sampling $(19 \%, 95 \%$ CI 12.7-25.1) fully realized how grave the problem was. But at the same time $2 / 3$ or 505 respondents (63\%, 95\% CI 62.2-63.3) knew that pregnant women and breast-feeding mothers needed to consume iodine in greater quantities; and 224 (86.8\%, 95\% CI 82.3-91.3\%) out of 258 people who had difficulty answering this question didn't have any medical education.

Table 2 contains answers given to questions on activities that are applied to prevent iodine deficiency. Only 134 respondents (17\%,
95\% CI 10.3-23.0\%) agreed that consumption of table iodized salt was enough for preventing iodine deficiency, $15 \%$ from group 1 , and $21 \%$ from group 2: About half of total 805 respondents, 420 people $(52 \%, 95 \%$ CI $51.6-52.8 \%)$ thought that iodized salt only wasn't enough to prevent iodine deficiency. And there were statistically significantly more respondents in group 1 than among medical workers who were sure iodized salt consumption was enough to make up for iodine concentration in a body or who had difficulty answering this 
Table 2

Ways to prevent iodine deficiency in households

\begin{tabular}{|c|c|c|c|c|c|c|c|c|c|}
\hline \multirow{2}{*}{$\begin{array}{c}\text { Answer } \\
\text { to a question }\end{array}$} & \multicolumn{3}{|c|}{ Total } & \multicolumn{3}{|c|}{ Not related to medicine } & \multicolumn{3}{|c|}{ Medical workers } \\
\hline & abs. & $\%$ & $\mathrm{CI}$ & abs. & $\%$ & $\mathrm{CI}$ & abs. & $\%$ & $\mathrm{CI}$ \\
\hline \multicolumn{10}{|c|}{ Can iodized salt consumption completely eliminate iodine deficiency in a body? } \\
\hline Yes & 134 & 17 & $10.3-23.0$ & 89 & 15 & 7.6-22.4 & 45 & 21 & $9.4-33.4$ \\
\hline No & 420 & 52 & $.6-5$ & 289 & 49 & $.8-54.3^{*}$ & 131 & 10 & $3.1^{*}$ \\
\hline Difficult t & 251 & 31 & $25.5-36.9$ & 217 & 36 & $30.1-42.9^{*}$ & 34 & 13 & $0.0-25.7^{*}$ \\
\hline \multicolumn{10}{|c|}{ What do you apply to eliminate iodine deficiency in a body? } \\
\hline odized salt & 392 & 49 & $48.1-49.3^{* *}$ & 259 & 44 & $37.5-49.6^{*}$ & 133 & 63 & $55.1-71.5^{*}$ \\
\hline $\begin{array}{l}\text { BAA to foo } \\
\text { tivitamin }\end{array}$ & 171 & 21 & $15.1-27.4$ & 112 & 19 & $11.6-26.1$ & 59 & 28 & $16.3-39$ \\
\hline ea food & 471 & 59 & $57.9-59.1^{* *}$ & 336 & 19 & $51.2-61.8^{*}$ & 135 & 64 & $16.3-39.6^{*}$ \\
\hline Nalnuts a & 226 & 28 & $22.2-33.9$ & 167 & 57 & $21.3-34.9$ & 59 & 28 & $16.3-39.6$ \\
\hline ther products rich & 236 & 17 & 7 & 224 & 17 & 9. & 74 & 19 & 4 \\
\hline Jothing & 96 & 12 & $5.5-18.4$ & 82 & 14 & $6.3-21.2$ & 14 & 7 & $0.0-20.2$ \\
\hline
\end{tabular}

Note: * means discrepancies between groups 1 and 2 are statistically significant, $p \leq 0.05$;

** means discrepancies in a number of answers given by overall sampling are statistically significant in comparison with a number of answers given by medical workers, $\mathrm{p} \leq 0.05$.

question. 392 respondents $(49 \%, 95 \%$ CI 48.1-49.3) consumed iodized salt, but in addition to it, respondents also mentioned sea food (471 people, $58.5 \%, 95 \%$ CI 57.9-59.1\%), biologically active additives to food (BAA) or multivitamin preparations (171 people, $21.2 \%$, CI 15.1-27.4\%), walnuts (226 people, $28.1 \%$, $95 \%$ CI $22.2-33.9 \%$ ), and other products which are rich with iodine (236 people, $17.4 \%$, 95\% CI 11.1-23.7\%). And medical workers mentioned iodized salt consumption as a way to prevent iodine deficiency disorders statistically significantly more frequently, that respondents without medical education; and as for sea food consumption, they mentioned it statistically significantly less frequently than people from group 1.

Therefore, we can observe there is lower awareness about IDD-related issues as well as ways to prevent them both among population as a whole, and medical workers as well.

Although only $48.7 \%$ (95\% CI 48.1$49.3 \%$ ) stated they permanently consumed iodized salt, objectively it is consumed in much greater quantities and it is confirmed by volumes of its sales in retail networks. As per monitoring data collected in 2016-2017, io- dized salt sales accounted for $71.2 \%-81.5 \%$ of overall salt sales, and it didn't include sales of salt with natural iodine contents (for example, sea salt). Such sales volumes are due to sufficient manufacture of rock salt and table salt in the country which are the most popular salt types among consumers and due to relatively high prices on imported salt as well. We should take into account that in some regions iodized salt accounts for 70$90 \%$ of the overall salt volumes sold through retail networks. And for comparison, if we look at countries where "people are free to choose which salt to consume", only $50-60 \%$ respondents state they permanently consume iodized salt $[13,14,15]$.

At present a lot of food products enriched with iodine are manufactured in Belarus. Bearing that in mind, it was particularly important to take into account all possible sources of iodine as well as conditions for persistent and sufficient iodine consumption by population, on one hand, and to reveal probable excess introduction of the examined micronutrient, on the other hand. We substantiated different models for assessing iodine introduction with food (Table 3) [16]. 
Table 3

Models for assessing alimentary iodine introduction

\begin{tabular}{|c|l|l|}
\hline Model & \multicolumn{1}{|c|}{ Iodine contents } & \multicolumn{1}{c|}{ Consumption } \\
\hline Model 1 & $\begin{array}{l}\text { Natural in all groups of food } \\
\text { products }\end{array}$ & $\begin{array}{l}\text { Average consumption (median) of all food products } \\
\text { High level (90-95 percentile) of food products consumption } \\
\text { for all groups }\end{array}$ \\
\hline Model 2 & $\begin{array}{l}\text { Natural in some food products; } \\
\text { sausages and bakery are made } \\
\text { with using iodized salt }\end{array}$ & $\begin{array}{l}\text { Average consumption (median) of all food products } \\
\text { High level }(90-95 \text { percentile) of food products consumption } \\
\text { for all groups }\end{array}$ \\
\hline & $\begin{array}{l}\text { Natural in some food products; } \\
\text { sausages are made with using } \\
\text { iodized salt; bakery and dairy } \\
\text { products are made with using } \\
\text { iodized salt or iodcasein, eggs are } \\
\text { biologically enriched with iodine }\end{array}$ & $\begin{array}{l}\text { Average consumption (median) of all food products, a share } \\
\text { of enriched food products may account for 10, 50 and 100\% } \\
\text { of the overall food consumption }\end{array}$ \\
& $\begin{array}{l}\text { High level (90-95 percentile) of food products consumption } \\
\text { for all groups, a share of enriched food products may account } \\
\text { for 10,50 and 100\% of the overall food consumption }\end{array}$ \\
\hline
\end{tabular}

Iodine introduction estimated as per Model 1 gave us average consumption with food equal to only $92 \mu \mathrm{g}$ a day and it was only $60 \%$ of the physiological need ( $150 \mu \mathrm{g}$ a day). But if we take high levels of consumption within the same model, iodine contents in a daily ration go up to $234.2 \mu \mathrm{g}$ a day and it is even greater than the physiological need. However, this model is far too theoretical and unlikely to be met in practice, only in case of people who keep a specific high-calorie diet (for example, sportsmen).

As application of iodized salt in food products manufacturing is fixed in the national legislation of Belarus ${ }^{2}$, iodine introduction with food is more likely to occur according to Model 2. Iodine contents here amount to $157.4 \mu \mathrm{g}$ a day when food consumption is average and to $449.3 \mu \mathrm{g}$ a day when food consumption level is high. If we apply exaggerated scenarios (Model 3) and assume that a consumer uses 5 extra grams of iodized salt adding it to cooked food, we naturally see further increase in iodine contents in daily consumption, within 366-879.9 $\mu \mathrm{g}$ a day range. It still doesn't exceed the upper limit of safe iodine consumption $(1,100 \mu \mathrm{g}$ a day).

It is necessary to monitor iodized salt consumption as it helps to guarantee that population consumes this element in sufficient quantities, especially when there are a lot of recommendations to reduce salt consumption. WHO experts note that a decrease in sodium quantities consumed with salt is a direct economically efficient health preservation technique as it potentially allows to reduce incidence and mortality caused by certain noninfectious diseases and to lower expenses on medical care. According to these recommendations, at present adults are to reduce their daily sodium consumption to 2 grams that corresponds to 5 grams of salt (and it concerns all adults, both with primary hypertension and without it); as for children, maximum consumption recommended for them should be adjusted as per their need in energy and it will be substantially lower relative to adults' needs $[17,18,19]$.

Any research on iodine consumption based on calculated values should be confirmed by objective data on provision with iodine. Actual provision with iodine can be validated with assessment of iodine excretion with urine and dynamics in thyroid gland diseases caused by iodine deficiency. Figure 1 shows results of monitoring over iodine excretion with urine starting from 2001. The data prove there is no iodine deficiency as ioduria median

\footnotetext{
${ }^{2}$ Sanitary standards and rules entitled "Requirements to food raw materials and food products" approved by the Order issued by the Belarus Public Healthcare Ministry on June 21, 2013 No. 52. - Minsk, 2013. [web-source]. - URL: http://rcheph.by/news/postanovlenie-52-ot-21-iyunya-2013-g-ob-utverzhdenii-sanitarnykh-norm-_1386688238.html (date of visit November 20, 2018).
} 


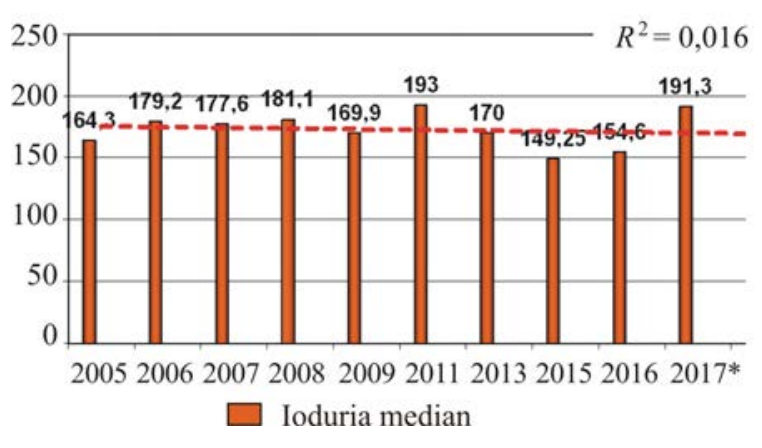

Figure 1. Monitoring over iodine excretion with urine in representative groups of children living in Belarus (2001-2017)

in children is higher than $100 \mu \mathrm{g} / \mathrm{l}$ in all the accomplished examinations.

There is another one reliably estimated parameter related to provision with iodine; it is prevalence of simple goiter in the overall population and among children younger than 18 as this thyroid gland disease is caused by iodine deficiency. Incidence rate for simple goiter decreased from 325.0 per 100 thousand people in 2000 to 51.51 per 100 thousand people in 2017 (Figure 2). An authentic, though less significant, decrease in incidence rate was registered among children younger than 18; it amounted to 136.31 per 100 thousand people.

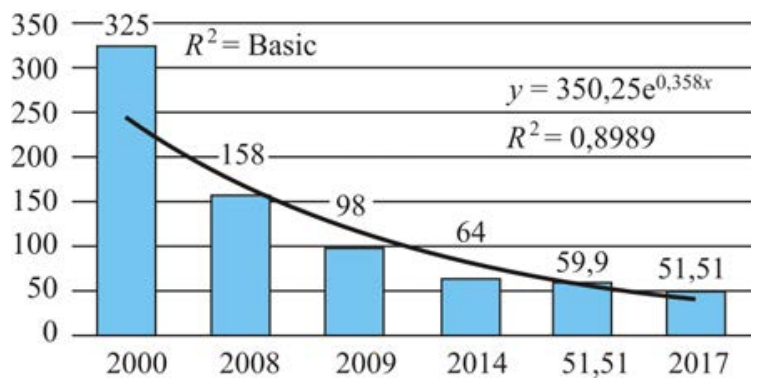

Figure 2. Dynamics in incidence rate for simple goiter (per 100 thousand people) over 2000-2017

Morbidity with primary congenital hypothyroidism diagnosed as per data obtained via neonatal screening is applied as an exact indicator for nutritional provision with iodine among newborns and their mothers [20]. In Belarus neonatal screening is performed in accordance with the consensus reached by the The European Society for Pediatric Endocrinology [21]. Frequency of congenital thyroid dysfunctions detected in a country amounts to such a value that proves there is no iodine deficiency in Belarus as it is equal to those detected in other European countries where iodine deficiency is also absent. In 2014 it amounted to 1:4,216 newborns out of 118,064 children (totally 118,697 children were born). The second screening stage also revealed positive trends; incidence with congenital hypothyroidism was equal to 1.96 per 100 thousand people in 2006, but it didn't exceed 0.94 per 100 thousand people in 2017.

Conclusion. The complex research which we performed is a convincing evidence that the national program aimed at eliminating IDD is quite efficient and it allows Belarus to maintain a status of a country with relevant iodine consumption. The chosen strategy that envisages obligatory use of iodized salt in food manufacturing and catering as it is fixed in the national legislation allows to provide sufficient iodine introduction with food and secures a margin necessary for a decrease in salt consumption by population. And here there is no risk related to excess introduction of iodine with food products enriched with this element. Nevertheless, questioning performed among population revealed that awareness about IDD issues decreased both among population in general and among medical workers as well; they were also less aware about a contribution made by iodized salt into IDD prevention. Some people believe that sporadic consumption of food products with high iodine contents, consumption of BAA to food, or replacing simple salt with natural sea salt to a great extent provide iodine deficiency prophylaxis. Given that, a certain deterioration of iodine provision among populations is rather probable and it may occur in the nearest future.

If population is informed about risks, it will allow, together with other strategic activities (medical and hygienic monitoring), to implement persistent strategy aimed at eliminating iodine deficiency in Belarus. We should take into account basic sources of information that people prefer to use, basically they are medical personnel and mass media, including the Internet. 
Our complex research convincingly proves that the national program aimed at eliminating iodine deficiency is quite efficient and it allows Belarus to maintain a status of a country where population consumes iodine in proper amounts. The chosen strategy that envisages obligatory use of iodized salt in food manufacturing and catering as it is fixed in the national legislation allows to provide sufficient iodine introduction with food and secures a margin necessary for a decrease in salt consumption by population. And here there is no risk related to excess introduction of iodine with food products enriched with this element.

Nevertheless, certain data indicate that both population in general and medical workers as well are now not properly aware about issues related to iodine deficiency and they don't fully comprehend a key role that iodized salt plays in prevention of the above men- tioned IDD. If this trend persists and people continue to be poorly aware about efficient prevention activities it will lead to a probable decrease in the existing iodine provision among population, Negative outcomes may be an increase in morbidity with IDD. Consequently, it is vital to activate an information campaign aimed at both population in general and medical workers which will be implemented via the most efficient up-to-date communication means (social networks, the Internet, etc.). All the above mentioned, together with activities implemented in the sphere of hygienic and medical monitoring, will help to preserve long-term stability in the national system for iodine deficiency prevention.

Funding. The research was not granted any sponsor support.

Conflict of interests. The authors state there is no any conflict of interests.

\section{References}

1. Zimmermann M.B. Iodine deficiency in industrialised countries. Geographical and geological influences on nutrition. Proceedings of the Nutrition Society, 2010, no. 69, pp. 133-43. DOI: $10.1017 / \mathrm{s} 0029665109991819$

2. A guide for program managers. Assessment of iodine deficiency disorders and monitoring their elimination.World Health Organization, UNICEF, ICCIDD, 2008, vol. 3, 98 p. Available at: http:// www.who.int/nutrition/publications/micronutrients/iodine deficiency/9789241595827/en/ (08.11.2018).

3. GerasimovG.A.OnovykhrekomendatsiyakhVOZiYuNISEFpoprofilaktikeyododefitsitnykhzabol evaniy [About New Recommendation of WHO and UNISEF for prevention of Iodine Deficiency Disorders]. Klinicheskayaieksperimental'nayatireoidologiya, 2008, vol. 4, no. 1, pp. 2-7 (in Russian).

4. Pearce E.N., Andersson M., Zimmermann M.B. Global iodine nutrition: Where do we stand in 2013? Thyroid, 2013, vol. 23, no. 5, 523 p. DOI: 10.1089/thy.2013.0128

5. Prete A., ParagliolaR.M., Corsello M. Iodine Supplementation: Usage "with a Grain of Salt". International Journal of Endocrinology, 2015, no. 312305, pp. 1-8. DOI:10.1155/2015/312305

6. Kolomiets N.D., Mokhort T.V., Fedorenko E.V. [et al.]. Problemadefitsitayodaiputieeresheniya v Respublike Belarus' [The problem of Iodine Feficiency and its Solution in the Republic of Belarus].Gigienaisanitariya, 2016, no. 5, pp. 417-422 (in Russian).

7. Mokhort T.V., Kolomiets N.D., Petrenko S.V., Fedorenko E.V., Mokhort E.G. Dinamicheskii monitoring yodnoiobespechennosti v Belarusi: rezul'tatyiproblemy [Dynamic monitoring of iodine sufficiency in Belarus: results and problems]. Problemyendokrinologii, 2018, vol. 64, no. 3, pp. 170-179 (in Russian).

8. Gerasimov G.A., vanderHaar F., Lazarus J.H. Obzor vozmozhnykh strategii profilaktiki yodnogo defitsita v stranakh Yugo-Vostochnoi Evropyi Tsentral'noi Azii: 2009-2016 [Overview of Iodine Deficiency Prevention Strategies in the South-Eastern Europe and Central Asia Region: 2009-2016]. Klinicheskayaieksperimental'nayatireoidologiya, 2017, vol. 13, no. 4, pp. 16-22 (in Russian).

9. Fortification of food-grade salt with iodine for the prevention and control of iodine deficiency disorders. World Health Organization, 2014, 45 p. Available at:http://www.who.int/nutrition/publications/guidelines/fortification_foodgrade_saltwithiodine/en/ (07.11.2018).

10. Völzke H., Caron P., Dahl L., de Castro J. [et al.]. Ensuring Effective Prevention of Iodine Deficiency Disorders. Thyroid, 2016, vol. 26, no. 2, pp. 189-196. DOI: 10.1089/thy.2015.0543 
11. Lee S.Y., Chang D.L., He X. [et al.]. Urinary iodine excretion and serum thyroid function in adults after iodinated contrast administration. Thyroid, 2015, vol. 25, no. 5, pp. 471-477. DOI: $10.1089 /$ thy.2015.0024

12. IDD NEWSLETTER, 2006, vol. 23, no. 2. Available at: http://www.ign.org/cm_data/IDD-NL2006-2.pdf (07.11.2018).

13. Soboleva D.E., Dora S.V., Karonova T.L. [et al.]. Otsenka effektivnosti profilaktiki defitsita yoda u vzroslogo naseleniya Sankt-Peterburga [Assessment of iodine profhylaxis effectiveness in adult population of Saint Petersburg]. Consilium Medicum, 2017, vol. 19, no. 4, pp. 65-69 (in Russian).

14. Mel'nichenko G.A., Troshina E.A., Platonova N.M. [et al.]. Osvedomlennost' naseleniya Rossii o yododefitsitnykh zabolevaniyakh i sposobakh ikh profilaktiki [The awareness of Russians about iodine deficiency diseases and methods of it's prevention]. Klinicheskaya i eksperimental'naya tireoidologiya, 2016, vol. 12, no. 3, pp. 25-30 (in Russian).

15. Pastorelli A.A., Stacchini P., Olivieri A. Daily iodine intake and the impact of salt reduction on iodine prophylaxis in the Italian population. European Journal of Clinical Nutrition, 2015, vol. 69, no. 2, pp. 211-215. DOI: 10.1038/ejen.2014.206

16. Fedorenko E.V., Kolomiets N.D., Mokhort T.V. [et al.]. Metodologiya otsenki riska zdorov'yu, assotsiirovannogo s obogashcheniem pishchevoy produktsii (na primere yoda) [Methodology for Health Risk Assessment Associated with the Fortified Food (iodine as an example)]. Sovremennyeproblemysostoyaniyaievolyutsiitaksonovbiosfery. Moscow, GEOKhI RAN Publ., 2017, no. 26, pp. 157-162 (in Russian).

17. Harding K.B., Peña-Rosas J.P., Webster A.C. [et al.]. Iodinesupplementation for women during the preconception, pregnancy and postpartum period. The Cochrane database of systematic reviews, 2017, no. 3. DOI: 10.1002/14651858.cd011761.pub2

18. K.S. Knust, A.M. Leung. Iodine: Basic Nutritional Aspects. Molecular, Genetic, and Nutritional Aspects of Major and Trace Minerals, 2017, pp. 133-141. Available at: https://www.sciencedirect.com/science/article/pii/B9780128021682000117 (21.11.2018).

19. Sullivan K.M., Perrine C.G., Pearce E.N., Caldwell K.L. Monitoring the iodine status of pregnant women in the United States. Thyroid, 2013, vol. 23, no. 4, pp. 520-521. DOI: 10.1089/thy.2012.0217

20. Zimmermann M.B., Aeberli I., Torresani T., Bürgi H. Increasing the iodine concentration in the Swiss iodized salt program markedly improved iodine status in pregnant women and children: a 5-y prospective national study. The American Journal of Clinical Nutrition, 2005, vol. 82, no. 2, pp. 388-392. DOI: $10.1093 /$ ajen.82.2.388

21. Léger J., Olivieri A., Donaldson M. [et al.]. European Society for Paediatric Endocrinology consensus guidelines on screening, diagnosis, and management of congenital hypothyroidism.The Journal of Clinical Endocrinology \& Metabolism, 2014, vol. 99, no. 2, pp. 363-384. DOI: 10.1210/jc.2013-1891

Phedorenko E.V., Kolomiets N.D., Mokhort T.V., Volchenko A.N., Mokhort E.G., Petrenko S.V., Sychik S.I. Risk communication as a component that provides stability of strategy aimed at eliminating diseases caused by iodine deficiency in Belarus. Health Risk Analysis, 2019, no. 1, pp. 58-67. DOI: 10.21668/health.risk/2019.1.06.eng

Received: 02.02.2019

Accepted: 24.02 .2019

Published: 30.03.2019 
UDC 616.99: 578.426

DOI: $10.21668 /$ health.risk/2019.1.07.eng

\title{
MORBIDITY WITH TICK-BORNE VIRAL ENCEPHALITIS IN SOME REGIONS IN URALSKIY FEDERAL DISTRICT WITH PREDICTIVE ESTIMATE OF SHORT-TERM EPIDEMIOLOGIC SITUATION
}

\author{
V.A. Mishchenko ${ }^{1,2}$, O.V. Ladygin ${ }^{1}$, I.P. Bykov ${ }^{1}$, J.A. Zakharova ${ }^{1}$, \\ A.G. Sergeev ${ }^{1,3}$, I.A. Kshnyasev ${ }^{2}$ \\ ${ }^{1}$ Rospotrebnadzor's Yekaterinburg Research Institute of Viral Infections, 23 Letnyaya Str., Yekaterinburg, 620030, \\ Russian Federation \\ ${ }^{2}$ Institute of Plant and Animal Ecology of the Urals Department of Russian Academy of Science, 2028 Marta Str., \\ URAN, Yekaterinburg, 620144, Russian Federation \\ ${ }^{3}$ Ural State Medical University of the RF Public healthcare Ministry, 3 Repina Str., 630028, Yekaterinburg, \\ Russian Federation
}

Extrapolation prediction of epidemic situation as per tick-borne viral encephalitis (TVE) on endemic territories that is based on analyzing time rows of morbidity is a promising approach to be applied in predictive medical-ecological and epidemiologic research.

The authors examined long-term dynamics showing both number of people who suffered from tick bites and morbidity with tick-borne viral encephalitis (TVE) in 4 regions in the Ural Federal District over 2007-2017.

We applied a sum of harmonic functions as a mathematic model; parameters of the functions were detected with Levenberg-Marquardt procedure for non-linear estimates. The technique is flexible and it allows both to apply parameters of harmonic fluctuation that are common for all 4 regions and to estimate parameters that differ in various regions and are of special interest (average long-term values and other fluctuation parameters). One of the research goals was to estimate dynamics in number of people who suffered from tick bites and morbidity with TVE in the Ural Federal District regions over the examined period and to predict epidemiologic situation for the coming years. To do that, we built several harmonic regression models with different number of estimated parameters. To compare and rank the models, we applied Akaike consistent information criterion that determines optimality as a compromise between a model accuracy and complexity.

Our analysis of morbidity with TVE over 2007-2017 in Sverdlovsk, Chelyabinsk, Tyumen, and Kurgan region allowed us to quantify discrepancies in average long-term parameters between these Ural Federal District regions. The highest average long-term morbidity was fixed in Kurgan region; the lowest one, in Sverdlovsk and Chelyabinsk region. But a number of people who suffered from tick bites was higher in Sverdlovsk, Chelyabinsk, and Tyumen region than in Kurgan region over the same period. We showed that long-term fluctuations in ticks activity in the Ural Federal District can be considered in-phase and it can possibly mean there is regional synchronization. We detected quasi-periods of cycles both for number of people bitten by ticks and morbidity with TVE and built a short-term prediction for epidemic situation as per TVE in the region on the basis of the proposed harmonic model for a period up to 2022; a probable TVE morbidity peak can be reached in 2020-2021.

Key words: tick-borne viral encephalitis, morbidity, number of victims, modeling, prediction, selection of models, cyclic fluctuations, parameters.

(c) Mishchenko V.A., Ladygin O.V., Bykov I.P., Zakharova J.A., Sergeev A.G., Kshnyasev I.A., 2019

Vladimir A. Mishchenko - Researcher at the Laboratory for transmissive infections and tick-borne encephalitis, Research Engineer at the laboratory of evolutionary ecology (e-mail: innamoramento23@yandex.ru; tel.: +7 (343) 261-99-47; ORCID: https://orcid.org/0000-0003-4280-283X).

Oleg V. Ladygin - Leading Researcher, Head of the laboratory of transmissive infections and tick-borne encephalitis (e-mail: alibabey@mail.ru; tel.: +7 (343) 261-99-47).

Ivan P. Bykov - Candidate of Medicine, Senior Researcher at the laboratory of transmissive infections and tick-borne encephalitis (e-mail: i.p.bykov@mail.ru; tel.: +7 (343) 261-99-47; ORCID: https://orcid.org/0000-0002-5157-646X).

Julia A. Zakharova - Holder of the postdoctoral degree in medicine, Deputy Director for Science, Head of the department for epidemiology of viral infections, Chief Researcher (e-mail: z.y.alexandrovna@mail.ru; tel.: +7 (343) 261-99-47; ORCID: https://orcid.org/0000-0003-3416-0902).

Alexandr G. Sergeev - Holder of the postdoctoral degree in medicine, Professor, Head of the Microbiology, Virology and Immunology Chair, Head of the Department of Indication and Diagnosis of Viral Infections, Chief Researcher (e-mail: aldr131250@yandex.ru; tel.: +7 (343) 214-86-95).

Ivan A. Kshnyasev - Candidate of Science (Biology), Senior Researcher at the laboratory of population ecology and modeling (e-mail: kia@ipae.uran.ru; tel.: +7 (343) 210-38-58). 
Since tick-borne viral encephalitis (TVE) was discovered in 1937 and up to now epidemiology of the disease has changed greatly; these changes were primarily caused by occurrence of anthropurgic foci around cities located on endemic territories [1, 2]. Sverdlovsk, Chelyabinsk, Tyumen, and Kurgan regions are considered to be industrially developed with relatively high standards of living. These regions, excluding Kurgan region, are highly urbanized with specific weight of urban population in them being equal to $82,87,80$, and $62 \%$ respectively. Thus, population of Sverdlovsk region amounts to 4.4 million people and population density there is 22.6 people per 1 square kilometer. 3.5 million people live in Chelyabinsk region with population density there being 40.4 people per 1 square kilometer. Population of Tyumen region (without autonomous areas) is equal to 1.45 million people, and population density there is 8.2 people per 1 square kilometer; 0.85 million people live in Kurgan region with population density being 11.95 people per 1 square kilometer. All the above-mentioned regions are natural and anthropurgic foci of tick-borne infections [3-6].

Territories in Sverdlovsk, Chelyabinsk, and Kurgan regions are endemic in terms of TVE. As for Kurgan region, 19 out of 26 administrative territories there are endemic in terms of the disease [7]. Despite all specific and non-specific prevention activities performed by local public healthcare organizations and regional Rospotrebnadzor authorities, epidemic situation as per TVE remains rather complicated on endemic territories $[8,9]$.

Morbidity with TVE among population on endemic territories is known to depend directly on tick activity in spring and summer. There is a regular correlation between appliance for medical aid caused by a tick bite and morbidity [10]. People who haven't been vaccinated or whose vaccination hasn't been complete account for a considerable part of patients during annual peaks in morbidity with TVE in spring and summer. Rises and falls in morbidity on endemic territories are cyclic; this cyclicity is caused by biological factors (periodic changes in number of animals that are natural sources of nutrition for ticks) and weather and climatic factors (air temperature and humidity during a period when ticks are active) [11].

Growth in urban population resulted in significant increase in risk groups and, consequently, rise in morbidity with TVE. It called for changes in vaccination programs, namely, to switching from immunization that covered only occupational risk groups to mass vaccination of population in the Urals Federal District; as a result, over the last 10 years morbidity with TVE has decrease significantly, by 4 times in comparison with average long-term value, to be exact $[12,13]$.

From 1956 to 1999 there were rises and falls in morbidity that followed each other with an interval of 3-4 years. Since mass immunization against TVE was introduced in 1999, there has been a change in morbidity dynamics detected in the region $[12,14]$.

Our research goal was to describe dynamics in morbidity and number of people bitten by ticks in Chelyabinsk, Tyumen, Kurgan, and Sverdlovsk regions over 11 years (2007-2017) and draw up a short-time forecast for epidemic situation development based on mathematic modeling.

Data and methods. Long-term dynamics of morbidity with TVE in the Urals Federal District was examined on the basis of data taken from the Report Form No. 2 (state statistical reports) called "Data on infectious and parasitic diseases" provided by the Rospotrebnadzor Federal Center for Hygiene and Epidemiology. Data on people who were bitten by ticks in the Urals Federal District were taken from the annual State Reports on sanitaryepidemiologic welfare of the population issued by Rospotrebnadzor Regional Offices.

We found a logarithm of data on morbidity with TVE and number of people bitten by ticks to transform them into an additive scale and to stabilize the dispersion, We applied a sum of harmonic functions as a mathematical model:

$$
y=\Sigma\left[b_{i}+a_{i} \cos (\omega t+\varphi)\right],
$$

parameters of these functions (average value, amplitude, cyclic frequency, initial phase) were found with Levenberg - Marquardt non- 
linear procedure in "Statistica 12.0" applied software package (StatSoft). Flexibility of the procedure allows to both apply values of harmonic fluctuations parameters that are common for all regions and to assess contrasts existing between the regions that attracted our attention, for example, in average long-term values $\left(\Delta=b_{i}-b_{j}\right)$, in amplitudes $\left(\Delta=a_{i}-a_{j}\right)$, and other fluctuations parameters. The regions in the Urals Federal District were coded with slack variables - binary markers $(0$ or 1$)$; if a region was not included into a list of predictors, it set a reference (basic) level $\left(b_{0}\right)$, and contrasts for all the other regions were estimated against it. When regional markers are neglected, it creates a reduced model with overall estimation of parameters.

To compare and rank our models, we applied Akaike information criterion - AIC that determines optimality as a compromise between a model accuracy and complexity [15]. The lower $A I C$ value is, the more statistically relevant is a model. Models were compared on the basis of consistent Akaike information criterion calculated as per the following formula:

$$
C A I C=m \times \ln (R S S / m)+k \times[1+\ln (m)],
$$

where $m$ is a number of observations, RSS is a residual sum of squares or measure of variability not reproduced by a model, $k$ is a number of parameters. Therefore, the first summand in the formula measures accuracy of a model, and the second one, its complexity (number of parameters). This modification, in comparison with AIC, imposes stricter "penalties" for additional parameters [16-18].

"Weight" (relative plausibility) of each model calculated as per the following formula:

$$
w_{i}=\exp \left(-0,5 \times \Delta C A I C_{i}\right) / \Sigma \exp \left(-0,5 \times \Delta C A I C_{i}\right)
$$

was applied to rank and compare competing models. The obtained weights $\mathrm{w}_{\mathrm{i}}$ were interpreted as probabilities that $i$-th model was better than any other one from a variety of other pretender models. If weights were less than $10 \%$ different from $\mathrm{w}_{\max }$, models were considered to be of the same quality as the best one [15].
To assess dynamics in number of people bitten by ticks in the Urals Federal District regions over the observation period, and to predict how epidemiologic situation would develop in the next 5 years, we created several harmonic regression models with different number of estimated parameters.

A common logarithm of number of people bitten by ticks or average long-term morbidity for Kurgan region were taken as a reference (basic) level $\left(b_{0}\right)$ as the lowest number of people bitten by ticks was registered in this region out of all the considered ones, but the morbidity with TVE there was the highest.

We examined two interesting (working) models. The first one included binary ( 0 or 1$)$ predictors - markers for the regions in the Urals Federal District (Sverdlovsk, Chelyabinsk, and Tyumen region), for $b_{0}$ (basic level, Kurgan region), and fluctuations amplitudes. We applied amplitude value common for all the four regions in the second model. Cyclic frequency and initial phase were assumed to be common. The third model, or a "zero" one, included only an absolute term (average long-term morbidity common for all the regions). Model No. 2 was considered to be the most relevant to empirical data (Table 1), as the lowest CAIC value or the greatest "weight" ( $\mathrm{w}=0.989)$ was obtained for it. Therefore, given high statistical support, we can conclude that long-term fluctuations in number of people bitten by ticks change in common mode in the Urals Federal District.

A model for assessing morbidity with TVE consisted of two components. The first one reflected morbidity and changes occurring in it in the examined regions; the second one, in the RF in general.

We took each out of four regions as a reference level by turns and compared three models. We applied marker variables in the first model, both for average long-term morbidity and for fluctuations amplitude for regions in the Urals Federal District and the RF in general.

The second model included markers for the Urals Federal District regions, common assessment of amplitude for all four regions in the Urals Federal District and amplitude for morbidity in the RF in general; the third 
Models of harmonic fluctuations for showing dynamics in number of people bitten by ticks $\left(y=\log _{10}(N)\right)$ in 2007-2017 in the Urals Federal District regions

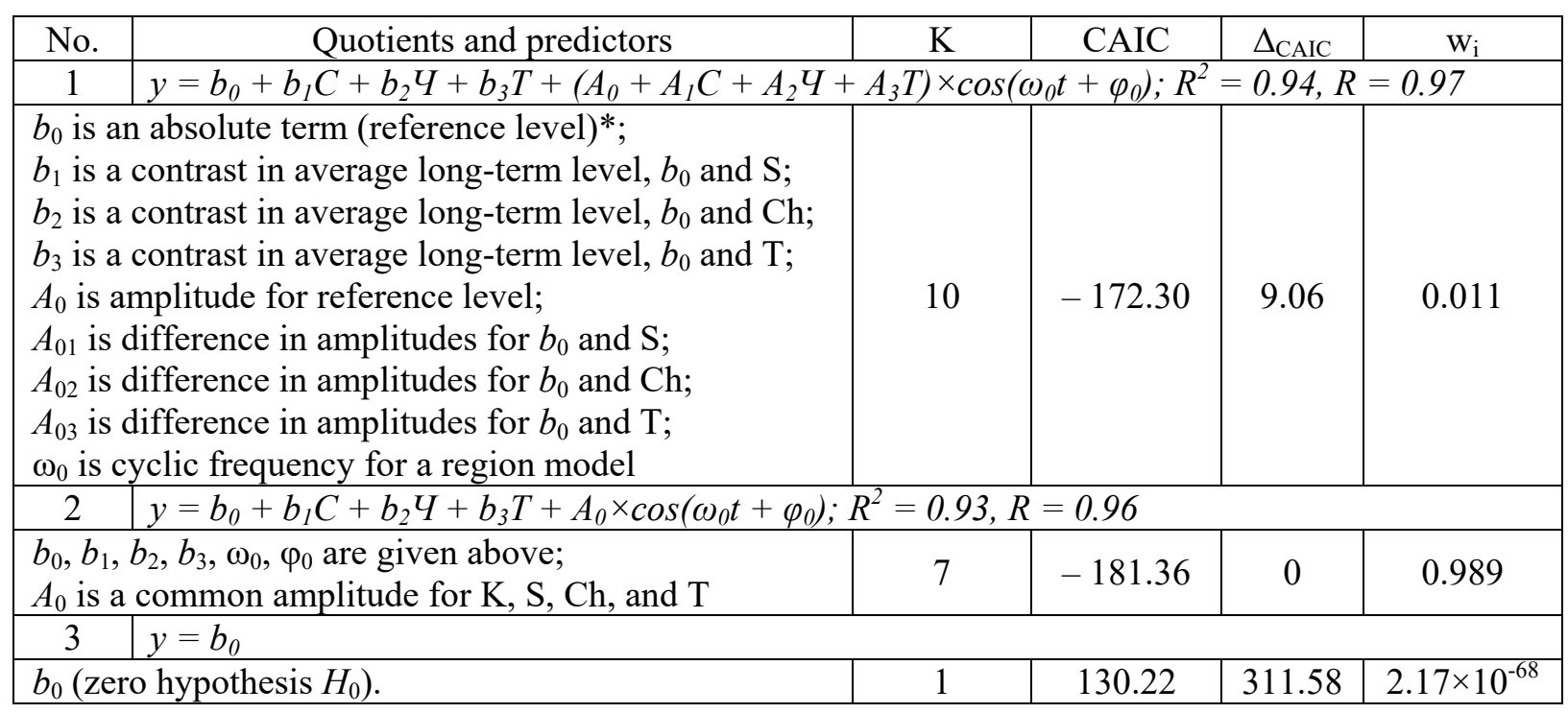

$\mathrm{N}$ o t e : CAIC is consistent Akaike information criterion; $\Delta_{\text {CAIC }}$ is differences in CAIC; $\mathrm{w}_{\mathrm{i}}$ is relative plausibility ("weight"); $\mathrm{k}$ is a number of parameters; * means that average value of the logarithm of number of people bitten by ticks in Kurgan region $(\mathrm{K})$ is taken in this model as reference level $\left(\mathrm{b}_{0}\right)$; $\mathrm{S}, \mathrm{Ch}$, and T are markers for Sverdlovsk, Chelyabinsk, and Tyumen region respectively.

model included an amplitude common for three regions (Sverdlovsk, Chelyabinsk, and Tyumen region), and specific amplitudes for Kurgan region and the RF in general. The fourth model that included only an absolute term was applied to compare predictions and to assess their quality.

This algorithm was also applied to assess morbidity with TVE in 2007-2017 (Table 2).

We chose Model No. 3 as a base for interpreting results of modeling morbidity with TVE as the lowest consistent Akaike criterion was obtained for it, and it also had the greatest "weight" among all the pretender models $(\mathrm{w}=0.96)$.

Results and discussion. Over 2007-2017 371,423 people were bitten by ticks in Sverdlovsk region, 1.743 TVE cases were registered, and average long-term morbidity amounted to 3.81 per 100 thousand people. 215,904 people were bitten in Chelyabinsk region, 1,078 TVE cases were registered $(2.98 \%$ \%000). 148,189 people were bitten in Tyumen region (data on the Khanty-Mansi Autonomous Area and YamalNenets Autonomous Area are not included in the figure) (5.92 per 100 thousand people).
Morbidity in Kurgan region where 54,906 people were bitten by ticks was the highest and amounted to $7.82 \%$. 0000 .

Determination quotient $\mathrm{R}^{2}$ (Table 1) amounted to $93 \%$ for a model that showed dynamics in a number of people bitten by ticks and it proves that this model chosen for interpretation is of high quality. The greatest number of people bitten by ticks over 11 years was registered in Sverdlovsk region, 34,674 people with hitting $95 \%$ interval from 30,200 to 39,811 . The lowest number of tick bites in 2007-2017 was registered in Kurgan region. As we ranked the examined regions in the Urals Federal District as per descending number of bitten people, we obtained the following sequence: Sverdlovsk region Chelyabinsk region - Tyumen region - Kurgan region (Table 3, Figure 1).

When creating a mathematical model for a number of people bitten by ticks, we detected cyclicity in the epidemic process with a quasi period equal to $8-8.5$ years (average $T=2 \pi / \omega=$ $=8.3$ years), with a confidence interval from 6.98 to 10.30 years. the created model allowed to detect a fluctuations amplitude $(p<0.0001)$. 
Таблица 2

Models of harmonic fluctuations for showing dynamics in morbidity (y) with TVE (per 100 thousand population) in 2007-2017 in the Urals Federal District regions

\begin{tabular}{|c|c|c|c|c|c|}
\hline № & Quotients and predictors & $\mathrm{k}$ & CAIC & $\Delta_{\text {CAIC }}$ & $\mathrm{W}_{\mathrm{i}}$ \\
\hline 1 & \multicolumn{5}{|c|}{$\begin{array}{l}y=b_{0}+\left\{x_{p} \times R F\right\}+\left(b_{1} S 1+b_{2} S 2+b_{3} S 3+\left(A_{0}+A_{01} S 1+A_{02} S 2+A_{03} S 3\right) \times\right. \\
\left.\times \cos \left(\omega_{0} t+\varphi_{0}\right)\right) \times\left[x_{p}=0\right]+\left(A_{1} \times \cos \left(\omega_{1} t+\varphi_{1}\right)\right) \times\left[x_{p}=1\right] ; R^{2}=0.78, R=0.88\end{array}$} \\
\hline \multicolumn{2}{|r|}{$\begin{array}{l}b_{0} \text { an absolute term (reference level); } \\
x_{p}-\text { контраст в СМУ PФ и } \mathrm{b}_{0} ; \\
b_{1} \text { is a contrast in average long-term morbidity, } b_{0} \text { and } \mathrm{S} 1 ; \\
b_{2} \text { is a contrast in average long-term morbidity, } \mathrm{b}_{0} \text { and } \mathrm{S} 2 ; \\
b_{3} \text { is a contrast in average long-term morbidity, } b_{0} \text { and } \mathrm{S} 3 ; \\
A_{0} \text { is amplitude for reference level; } \\
A_{01} \text { is difference in amplitudes for } b_{0} \text { and } \mathrm{S} 1 ; \\
A_{02} \text { is difference in amplitudes for } b_{0} \text { and } \mathrm{S} 2 ; \\
A_{03} \text { is difference in amplitudes for } b_{0} \text { and } \mathrm{S} 3 ; \\
\omega_{0} \text { is cyclic frequency for a region model (S); } \\
A_{1} \text { is an amplitude for the overall RF model; } \\
\omega_{1} \text { is cyclic frequency for the overall RF model. }\end{array}$} & 14 & 124.62 & 6.74 & 0.03 \\
\hline 2 & \multicolumn{5}{|c|}{$\begin{array}{l}y=b_{0}+\left\{x_{p} \times R F\right\}+\left(b_{1} S 1+b_{2} S 2+b_{3} S 3++A_{0} \times \cos \left(\omega_{0} t+\varphi_{0}\right)\right) \times\left[x_{p}=0\right]+ \\
+\left(A_{1} \times \cos \left(\omega_{1} t+\varphi_{1}\right)\right) \times\left[x_{p}=1\right] ; R^{2}=0.62, R=0.79\end{array}$} \\
\hline \multicolumn{2}{|r|}{$\begin{array}{l}b_{0}, x_{p}, b_{1}, b_{2}, b_{3}, \omega_{0}, \mathrm{~A}_{1}, \omega_{1} \text { are given above; } \\
A_{0} \text { ias a common amplitude for } b 0, \mathrm{~S} 1, \mathrm{~S} 2, \mathrm{~S} 3 .\end{array}$} & 11 & 139.97 & 22.00 & $1.62 \times 10^{-5}$ \\
\hline 3 & \multicolumn{5}{|c|}{$\begin{array}{l}y=b_{0}+\left\{x_{p} \times P \Phi\right\}+\left(b_{1} S 1+b_{2} S 2+b_{3} S 3+\left(A_{K O}+A_{C P} \times S_{C P}\right) \times \cos \left(\omega_{0} t+\varphi_{0}\right)\right) \times\left[x_{p}=0\right]+ \\
+\left(A_{1} \times \cos \left(\omega_{1} t+\varphi_{1}\right)\right) \times\left[x_{p}=1\right] ; R^{2}=0.77, R=0.88\end{array}$} \\
\hline \multicolumn{2}{|r|}{$\begin{array}{l}b_{0}, x_{p}, b_{1}, b_{2}, b_{3}, \omega_{0}, \mathrm{~A}_{1}, \omega_{1} \text { are givem above; } \\
A_{\mathrm{KR}} \text { is an amplitude for Kurgan region; } \\
A_{\mathrm{AV}} \text { is a difference between amplitudes for } \mathrm{S}_{\mathrm{KR}} \text { and } \mathrm{S}_{\mathrm{AV}} \\
\text { (average value as per } 3 \text { regions). }\end{array}$} & 12 & 117,88 & 0 & 0,96 \\
\hline 4 & $y=b_{0}$ & & & & \\
\hline \multicolumn{2}{|c|}{$b_{0}$ (zero hypothesis $H_{0}$ ). } & 1 & 195.94 & 78.06 & $1.08 \times 10^{-17}$ \\
\hline
\end{tabular}

$\mathrm{N}$ o t e : CAIC is consistent Akaike information criterion; $\Delta_{\text {CAIC }}$ is differences in CAIC; $\mathrm{w}_{\mathrm{i}}$ is relative plausibility ("weight"); $\mathrm{k}$ is a number of parameters; $\left\{\mathrm{x}_{\mathrm{p}} \times \mathrm{RF}\right\}$ is a summand in equations applied to take into account difference in average long-term levels between the RF and the examined regions; $\mathrm{x}_{\mathrm{p}}=0$ is a part of a model applied to show morbidity in the regions; $\mathrm{x}_{\mathrm{p}}=1$ is a part of a model applied to show morbidity in the RF; $b_{0}$ is an absolute term or a reference level which corresponds to average longterm morbidity in a chosen region; S1-3 are markers for the regions in the Urals Federal District.

Table 3

Parameters $(\theta)$, their standard errors (SE), and confidence intervals (CI) for the "best" model (from Table 1) for the logarithm of number of people bitten by ticks

\begin{tabular}{|l|c|c|c|c|c|c|c|c|}
\hline \multicolumn{1}{|c|}{ Parameters } & $\theta$ & $\mathrm{SE}(\theta)$ & $p$-value. & \multicolumn{2}{c|}{$95 \% \mathrm{CI}$} & \multicolumn{2}{c|}{$\theta \AA$} & \multicolumn{2}{c|}{$95 \% \mathrm{CI}$} \\
\hline $\begin{array}{l}\mathrm{b}_{0} \text { (average long-term level in } \\
\text { Kurgan region) }\end{array}$ & 3.69 & 0.03 & $<0.0001$ & 3.63 & 3.75 & 4,898 & 4,266 & 5,623 \\
\hline $\mathrm{b}_{1}$ (Sverdlovsk region) & 0.85 & 0.04 & $<0.0001$ & 0.75 & 0.93 & $34,674(+29,776)$ & 30,200 & 39,811 \\
\hline $\mathrm{b}_{2}$ (Chelyabinsk region) & 0.61 & 0.04 & $<0.0001$ & 0.53 & 0.70 & $19,953(+15,055)$ & 17,378 & 22,909 \\
\hline $\mathrm{b}_{3}$ (Tyumen region) & 0.45 & 0.04 & $<0.0001$ & 0.36 & 0.53 & $13,804(+8,906)$ & 12,023 & 15,488 \\
\hline $\begin{array}{l}\text { Common fluctuation amplitude } \\
\text { (S, Ch, T, and K) }\end{array}$ & 0.10 & 0.02 & $<0.0001$ & 0.06 & 0.15 & $\sim 26 \%$ & $\sim 15 \%$ & $\sim 41 \%$ \\
\hline $\begin{array}{l}\text { Cyclic frequency }\left(\omega_{0} \text { ) of fluc- }\right. \\
\text { tuations for a region model }\end{array}$ & -0.76 & 0.07 & $<0.0001$ & -0.90 & -0.61 & - & - & - \\
\hline
\end{tabular}

Note $: b_{0}$ is an absolute term (reference level) or an average value of the logarithm of a number of people bitten by ticks in Kurgan region; S, Ch, T, and K are markers for Sverdlovsk, Chelyabinsk, Tyumen, and Kurgan region respectively; $b_{1-3}$ are contrasts between each region in the Urals Federal District and Kurgan region; ${ }^{\circledR}$ means data are brought into an initial scale (number of people bitten by ticks) via potentiating logarithm values: $10^{(y)}=x$ - "anti-logarithm". 

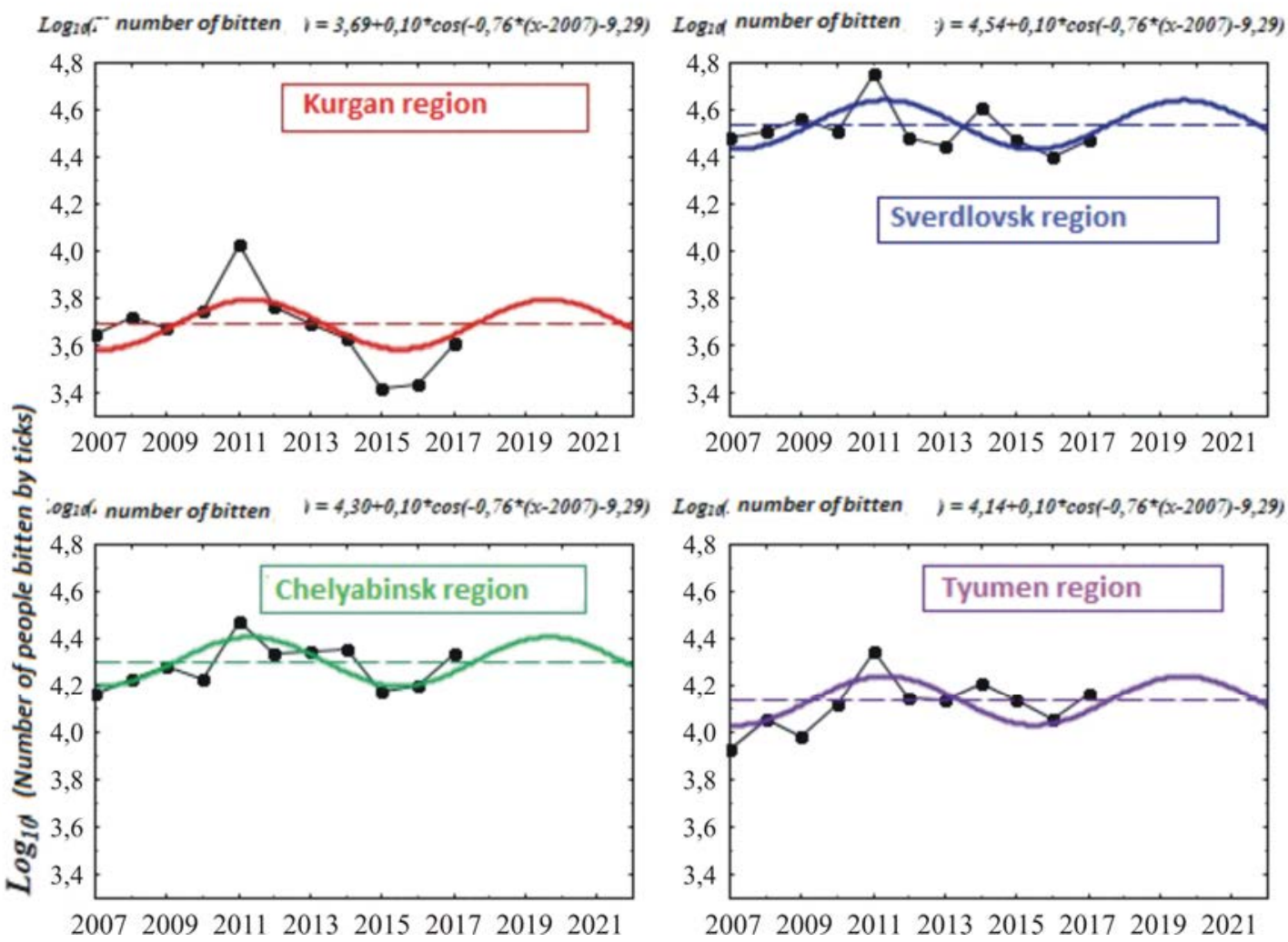

Figure 1. Dynamics in number of people bitten by ticks over 2007-2017 in four regions in the Urals Federal District and a forecast up to 2022

$\mathrm{N}$ o t e : dots on a polygonal line are observed values; broken straight lines show number of people bitten by ticks in the regions over 11 years; solid wavy lines represent values of logarithm of number of bitten people predicted by models for harmonic fluctuations

The greatest number of people bitten by ticks was detected in all four regions in the Urals Federal District in 2011. An increase amounted up to $26 \%$ from an average level calculated for 11 years with a confidence interval being equal to $15-41 \%$. Occurrence of a quasi period and amplitude allowed us to conclude that there was a cyclic dynamics in number of people bitten by ticks; this dynamics was most likely related to dynamics in populations of ticks and small mammals.

Substantial influence exerted by ecological and geographical factors on morbidity with TVE in the examined regions of the Urals Federal District was determined by value of the determination quotient $\mathrm{R}^{2}$ for this model; this value amounted to $77 \%$.

There are statistically significant discrepancies as per average long-term morbidity between four regions in the Urals Federal Dis- trict and average long-term morbidity in the RF in general (Table 4). Thus, average longterm morbidity in the examined regions (excluding Chelyabinsk region) differed significantly from average country level over 11 years. The greatest deviations from average long-term morbidity in the RF in general were detected in Kurgan and Tyumen region (the differences amounted to 6.03 and $4.13 \%$ 0000).

The highest average long-term morbidity was detected in Kurgan region where it was equal to 7.82 (CI: $6.63-9.01 \%$ \%000); this value was most probably caused by rises in the parameter that occurred in 2007-2012 with a local peak reached in 2011. the examined regions were ranked as per morbidity in descending order (Kurgan region - Tyumen region - Sverdlovsk region - Chelyabinsk region) and the results are shown in Table 5 and Figure 2. 
Table 4

Parameters $(\theta)$, their standard errors (SE), and confidence intervals (CI) for the best model (from Table 2) for harmonic fluctuations in morbidity with TVE

\begin{tabular}{|l|c|c|c|c|c|}
\hline \multicolumn{1}{|c|}{ Parameters } & $\theta$ & $\mathrm{SE}(\theta)$ & $p$-value & \multicolumn{2}{c|}{$95 \% \mathrm{CI}$} \\
\hline 1$) b_{0}$ (average long-term morbidity in Kurgan region) & 7.82 & 0.59 & $<0.0001$ & 6.63 & 9.01 \\
\hline$x_{p}(\mathrm{RF})$ & -6.03 & 0.99 & $<0.0001$ & -8.02 & -4.05 \\
\hline $\mathrm{b}_{1}$ (Sverdlovsk region) & -4.01 & 0.82 & $<0.0001$ & -5.67 & -2.36 \\
\hline $\mathrm{b}_{2}$ (Chelyabinsk region) & -4.84 & 0.82 & $<0.0001$ & -6.50 & -3.19 \\
\hline $\mathrm{b}_{3}$ (Tyumen region) & -1.90 & 0.82 & 0.03 & -3.56 & -0.25 \\
\hline Amplitude $(\mathrm{K})$ & 6.55 & 0.84 & $<0.0001$ & 4.85 & 8.25 \\
\hline Contrast in amplitudes [K]-[S, Ch, T] & -4.99 & 0.96 & $<0.0001$ & -6.93 & -3.05 \\
\hline 2) $b_{0}$ (average long-term morbidity in Sverdlovsk region) & 3.81 & 0.58 & $<0.0001$ & 2.64 & 4.97 \\
\hline$x_{p}(\mathrm{RF})$ & -2.02 & 0.98 & 0.05 & -3.99 & -0.04 \\
\hline $\mathrm{b}_{1}($ Chelyabinsk region) & -0.83 & 0.82 & 0.32 & -2.47 & 0.82 \\
\hline $\mathrm{b}_{2}$ (Tyumen region) & 2.11 & 0.82 & 0.01 & 0.47 & 3.76 \\
\hline $\mathrm{b}_{3}$ (Kurgan region) & 4.01 & 0.82 & $<0.0001$ & 2.36 & 5.67 \\
\hline 3$) b_{0}$ (average long-term morbidity in Chelyabinsk region) & 2.98 & 0.58 & $<0.0001$ & 1.81 & 4.14 \\
\hline$x_{p}(\mathrm{RF})$ & -1.19 & 0.97 & 0.23 & -3.16 & 0.77 \\
\hline $\mathrm{b}_{1}$ (Sverdlovsk region) & 0.83 & 0.82 & 0.32 & -0.82 & 2.47 \\
\hline $\mathrm{b}_{2}$ (Tyumen region) & 2.94 & 0.82 & 0.001 & 1.29 & 4.58 \\
\hline $\mathrm{b}_{3}$ (Kurgan region) & 4.84 & 0.82 & $<0.0001$ & 3.19 & 6.50 \\
\hline 4$) b_{0}$ (average long-term morbidity in Tyumen region) & 5.92 & 0.58 & $<0.0001$ & 4.75 & 7.08 \\
\hline$x_{p}$ (RF) & -4.13 & 0.98 & 0.0001 & -6.10 & -2.16 \\
\hline $\mathrm{b}_{1}$ (Sverdlovsk region) & -2.11 & 0.82 & 0.01 & -3.76 & -0.47 \\
\hline $\mathrm{b}_{2}$ (Chelyabinsk region) & -2.94 & 0.82 & 0.001 & -4.58 & -1.29 \\
\hline $\mathrm{b}_{3}$ (Kurgan region) & 1.90 & 0.82 & 0.03 & 0.25 & 3.56 \\
\hline Fluctuations amplitude common for S, Ch, and T & 1.57 & 0.48 & 0.002 & 0.60 & 2.53 \\
\hline Fluctuations amplitude for K & -4.99 & 0.96 & $<0.0001$ & -6.93 & -3.05 \\
\hline Cyclic frequency $\left(\omega_{0}\right.$ ) of fluctuations for region models & 0.59 & 0.04 & $<0.0001$ & 0.51 & 0.66 \\
\hline 5$)$ Fluctuations amplitude for the RF & 0.55 & 0.78 & 0.49 & -1.03 & 2.13 \\
\hline Cyclic frequency $\left(\omega_{1}\right.$ ) of fluctuations for the RF model & 0.44 & 0.75 & 0.56 & -1.08 & 1.96 \\
\hline
\end{tabular}

$\mathrm{N}$ o t e : $\mathrm{b}_{0}$ is an absolute term (reference level) showing average value of morbidity with TVE in a selected (reference) region; $\mathrm{S}, \mathrm{Ch}, \mathrm{T}$, and $\mathrm{K}$ are markers for Sverdlovsk, Chelyabinsk, Tyumen, and Kurgan regions respectively; $x p$ is a contrast between the RF and reference level; $b_{1-3}$ are contrasts between each region the Urals Federal District and reference level.

We should also note that we didn't detect any statistically significant discrepancies $(p=0.32)$ in average long-term morbidity between Sverdlovsk region and Chelyabinsk region; the issue most certainly requires further research.

Application of statistical models allowed to reveal cyclic changes (harmonic fluctuations) in morbidity with TVE in all the four regions in the Urals Federal District with a quasi period being equal to 10-11 years (average $T=2 \pi / \omega=10.6$ years) and a confidence interval from 9.52 to 12.31 .

It is well known that there are natural cyclic fluctuations in weather related to cyclicity observed in the solar activity as the great cycle of the Sun also lasts for 11 years [19]. As per data taken from literature, in previous years maximum in morbidity with TVE was observed in 1996 and 1999 in all the climatic zones in the Urals Federal District [19].

But at the same time, the highest average long-term morbidity and the greatest fluctuations amplitude was observed in Kurgan region (Figure 2). It can be due to a rise in morbidity in a period from 2007 to 2012 . The peak in morbidity was reached in Kurgan region, just as in three other regions, in 2010-2011. In those years morbidity was higher than its 

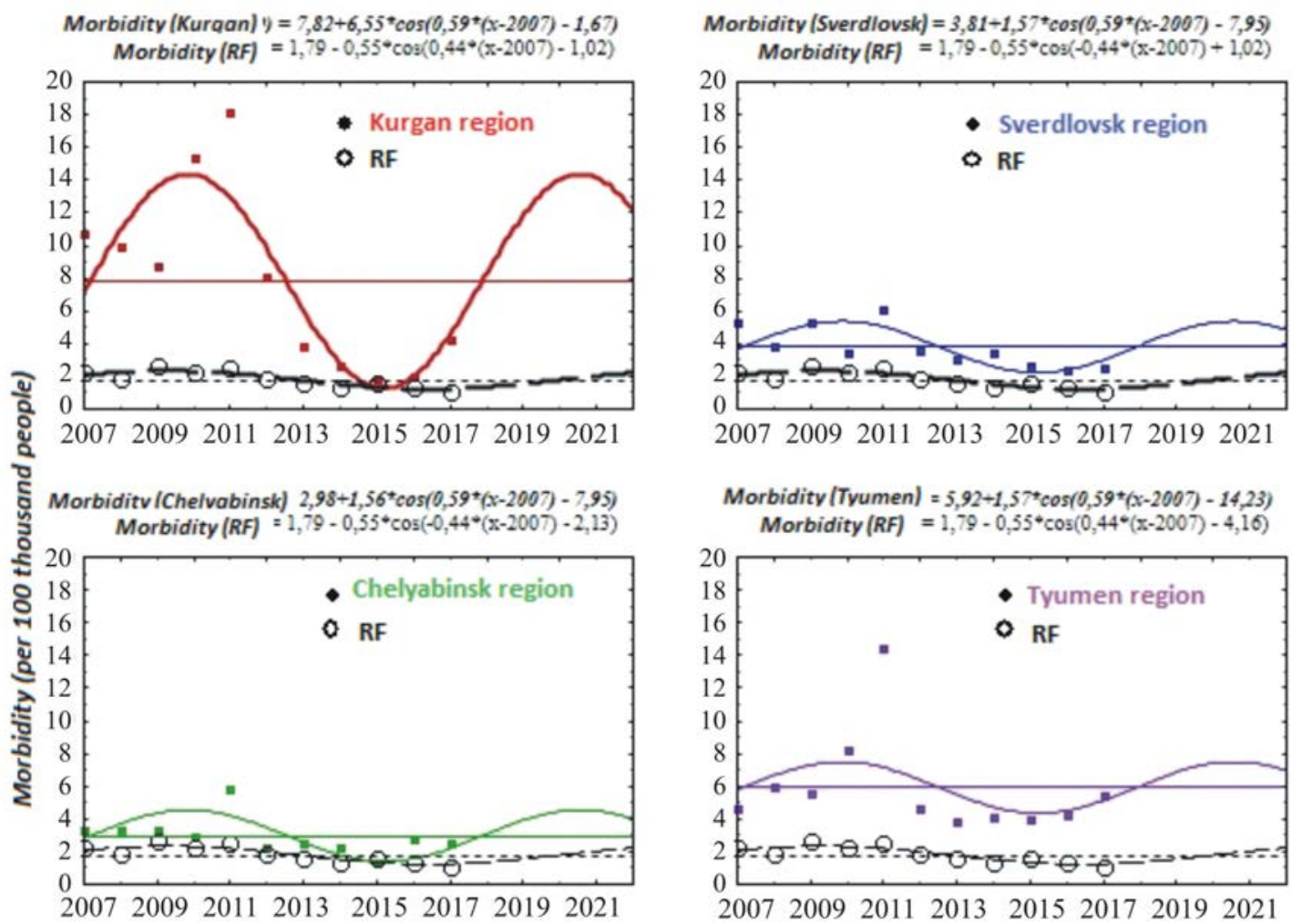

Figure 2. Dynamics in morbidity with TVE (per 100 thousand people) over 2007-2017 in four regions in the Urals Federal District and a forecast up to 2022

$\mathrm{N}$ o t e : dots (squares and rounds) are values being observed; solid straight lines show average long-term morbidity in the Urals Federal District regions; broken straight line shows average long-term morbidity in the RF in general; solid and broken curves show values predicted by models of harmonic fluctuations

average long-term level by $6.55 \%$ (CI: $4.85-8.25 ; p<0.0001)$. As per results obtained via statistical modeling, fluctuations amplitude observed in Sverdlovsk, Chelyabinsk, and Tyumen regions, was common for all three of them, and peak morbidity reached in this regions was higher than average long-term level by $1.57 \%$ (0000 (CI: $0.60-2.53 ; p=0.002$ ).

Conclusion. We analyzed morbidity with TVE over 2007-2017 years in Sverdlovsk, Chelyabinsk, Tyumen, and Kurgan regions; the analysis revealed statistically significant discrepancies between these regions in the Urals Federal District. The highest average long-term morbidity was registered in Kurgan region; the lowest, in Sverdlovsk and Chelyabinsk region. And at the same time, a number of people bitten by ticks over the same period was higher in Sverdlovsk, Chelyabinsk, and Tyumen region than in Kurgan region.
A smaller number of people bitten by ticks in Kurgan region against the other examined regions is most likely due to lower population in the region as there is always a direct correlation between population in a region and appliance for medical aid caused by tick bites. Extremely high morbidity with TVE in Kurgan region against all other regions is probably caused by both natural and social factors: there are several tick species that are infectious carriers (not only Ixodes, but also Dermacentor) and virus activity among them is also very high, specific and non-specific prevention activities performed in the region as regards TVE are not sufficient.

In our opinion, short-term forecasts for morbidity with TVE and appliance for medical aid caused by tick bites obtained on the basis of statistical models aren't indisputable as they are formed under influence exerted by many 
factors, and we require multi-factor analysis to take them all into account [20].

\section{Conclusions:}

1. We revealed statistically significant discrepancies between the four examined regions as per average long-term morbidity with TVE and number of people bitten by ticks. the highest average long-term morbidity was registered in Kurgan region (7.82 $\%$ 0000). Tyumen region followed (5.92), then Sverdlovsk region (3.81), and Chelyabinsk region (2.98). But as for number of people bitten by ticks, we observed a reverse descending sequence with maximum in Sverdlovsk region (34,674 people): Sverdlovsk region - Chelyabinsk region - Tyumen region - Kurgan region.

2. We made a forecast for morbidity with TVE and number of people bitten by ticks. In 2018-2022 we expect to see a rise in morbidity and number of people applying for medical aid due to tick bites in all the regions in the Urals Federal District. According to periodicity observed in the process (10-11 years), a peak in morbidity is most likely to occur in 2020-2021.

Funding. The research was not granted any sponsor support.

Conflict of interests. The authors state there is no any conflict of interests.

\section{References}

1. Ammosov A.D. Kleshchevoi entsefalit [Tick-borne encephalitis]. Kol'tsovo, Vektor-Best Publ., 2006, 115 p. (in Russian).

2. Korenberg E.I., Pomelova V.G., Osin N.S. Prirodnoochagovye infektsii, peredayushchiesya iksodovymi kleshchami [Infections with natural focality transmitted by ixodid ticks]. Moscow, Kommentarii Publ., 2013, 464 p. (in Russian).

3. Volkova L.I., Kovtun O.P., Tereschuk M.A. Klinicheskie osobennosti khronicheskogo kleshchevogo entsefalita i epilepsii Kozhevnikova na Srednem Urale [Clinical characteristics of chronical tickborne encephalitis and Kozhevnikov's epilepsia partialis continua in the Middle Urals]. Russkii zhurnal detskoi nevrologii, 2011, vol. 6, no. 2, pp. 3-10 (in Russian).

4. Zlobin V.I. Kleshchevoi entsefalit v Rossiiskoi Federatsii: etiologiya, epidemiologiya i strategiya profilaktiki [Tick-borne encephalitis in the Russian Federation: etiology, epidemiology and prevention strategy.]. Terra Medica, 2010, no. 2, pp. 13-21 (in Russian).

5. Luchinina S.V., Stepanova O.N., Pogodina V.V., Sten'ko E.A., Chirkova G.G. [et al.]. Sovremennaya epidemiologicheskaya situatsiya po kleshchevomu virusnomu entsefalitu v Chelyabinskoi oblasti [Modern Epidemiological Situation of Tick-Borne Encephalitis in Chelyabinsk Region, Russia]. Epidemiologiya i vaktsinoprofilaktika, 2014, vol. 75, no. 2, pp. 32-37 (in Russian).

6. Konkova-Reydman A.B., Ter-Bagdasaryan L.V. Sovremennye aspekty epidemiologii infektsii, peredayushchikhsya iksodovymi kleshchami [Modern aspects of epidemiology of ticks transmitted infections]. Epidemiologiya i infektsionnye bolezni, 2014, vol. 19, no. 5, pp. 26-31 (in Russian).

7. Yasyukevich V.V., Titkina S.N., Popov I.O., Davidovich E.A., Yasyukevich N.V. Klimatozavisimye zabolevaniya i chlenistonogie perenoschiki: vozmozhnoe vliyanie nablyudaemogo na territorii Rossii izmeneniya klimata [Climate-dependant diseases and arthropod vectors: possible influence of climate change observed in Russia]. Problemy ekologicheskogo monitoringa i modelirovaniya ekosistem, 2013, vol. 25, pp. 314-359 (in Russian).

8. Yastrebov V.K., Rudakov N.V., Shpynov S.N. Transmissivnye kleshchevye prirodno-ochagovye infektsii v Rossiiskoi Federatsii: tendentsii epidemicheskogo protsessa, aktual'nye voprosy profilaktiki [Transmissive tick-borne natural focal infections in the Russian Federation: trends of the epidemiological process, topical prophylaxis issues]. Sibirskii meditsinskii zhurnal, 2012, vol. 111, no. 4, pp. 91-93 (in Russian).

9. Il'in V.P., Andaev E.I., Balakhonov S.V., Pakskina N.D. Prognozirovanie zabolevaemosti kleshchevym virusnym entsefalitom v Rossiiskoi Federatsii v 2014 g., osnovannoe na mnogofaktornykh regressionnykh modelyakh [Morbidity Rate Forecasting for 2014 as Regards Tick-Borne Viral Encephalitis in the Territory of the Russian Federation Based on Multi-Factor Regression Models]. Problemy osobo opasnykh infektsii, 2014, no. 2, pp. 48-52 (in Russian). 
10. Noskov A.K., Il'in V.P., Andaev E.I., Pakskina N.D., Verigina E.V., Balakhonov S.V. Zabolevaemost' kleshchevym virusnym entsefalitom v Rossiiskoi Federatsii i po federal'nym okrugam $\mathrm{v}$ 2009-2013 gg., epidemiologicheskaya situatsiya v 2014 g. i prognoz na 2015 g. [Incidence of TickBorne Viral Encephalitis in the Russian Federation and across Federal Districts in 2009-2013. Epidemiological Situation in 2014 and Prognosis for 2015]. Problemy osobo opasnykh infektsii, 2015, no. 1, pp. 46-50 (in Russian).

11. Kiffner C., Zucchini W., Schomaker P., Vor T., Hagedorn P., Niedrig M., Rühe F. Determinants of tick-borne encephalitis in counties of southern Germany, 2001-2008. International Journal of Health Geographics, 2010, vol. 9, pp. 1-10. DOI: 10.1186/1476-072X-9-42

12. Heinz F.X., Stiasny K., Holzmann H. [et al.]. Vaccination and Tick-borne Encephalitis, Central Europe. Emerging Infectious Diseases, 2013, vol. 19, no. 1, pp. 69-76. DOI: 10.3201/eid1901.120458

13. Romanenko V.V., Kilyachina A.S., Yesyunina M.S., Ankudinova A.V., Pimenova T.A. Effektivnost' programmy massovoi immunoprofilaktiki kleshchevogo entsefalita [Efficiency of the program of mass immunoprophylaxis of Tick-Borne Encephalitis]. Biopreparaty. Profilaktika, diagnostika, lechenie, 2008, no. 2, pp. 9-14 (in Russian).

14. Yesyunina M.S., Romanenko V.V., Kilyachina A.S. Dlitel'nost' sokhraneniya postprivivochnogo immuniteta $\mathrm{k}$ virusu kleshchevogo entsefalita posle revaktsinatsii [Duration of post-vaccination immunity against tick-borne encephalitis following booster doses]. Trudy Instituta poliomielita $i$ virusnykh entsefalitov imeni M.P. Chumakova RAMN. Meditsinskaya virusologiya, 2015, vol. 29, no. 2, p. 132 (in Russian).

15. Akaike H. A new look at the statistical model identification. IEEE Transactions on Automatic Control, 1974, vol. 19, pp. 716-723.

16. Anderson, D.R., Burnham, K.P., White, G.C. Comparison of Akaike information criterion and consistent Akaike information criterion for model selection and statistical inference from capturerecapture studies. Journal of Applied Statistics, 1998, vol. 25, pp. 263-282.

17. Burnham K.P., Anderson D.R. Model selection and multimodel inference: a practical information-theoretic approach. New York, Springer Verlag Publ., 2002, 496 p.

18. Yang Y. Can the strengths of AIC and BIC be shared? A conflict between model indentification and regression estimation. Biometrika, 2005, vol. 92, no. 4, pp. 937-950.

19. Tsokova T.N., Kozlov L.B. Razrabotka matematicheskoi modeli prognozirovaniya zabolevaemosti kleshchevym entsefalitom [Development of mathematical model of forecasting of desease the virus of tick-born encephalitis]. Uspekhi sovremennogo estestvoznaniya, 2008, no. 6, pp. 12-16 (in Russian).

20. Stefanoff P., Rubikowska B., Bratkowski J., Ustrnul Z., Vanwambeke S.O., Rosinska M. A Predictive Model Has Identified Tick-Borne Encephalitis High-Risk Areas in Regions Where No Cases Were Reported Previously, Poland, 1999-2012. International Journal of Environmental Research and Public Health, 2018, vol. 15, no. 4, pp. 1-17. DOI: 10.3390/ijerph15040677

Mishchenko V.A., Ladygin O.V., Bykov I.P., Zakharova J.A., Sergeev A.G., Kshnyasev I.A. Morbidity with tick-borne viral encephalitis in some regions in uralskiy federal district with predictive estimate of short-term epidemiologic situation. Health Risk Analysis, 2019, no. 1, pp. 68-77. DOI: 10.21668/health.risk/2019.1.07.eng

Received: 06.11.2018

Accepted: 02.03.2019

Published: 30.03.2019 
UDC 614.4: 616.9

DOI: $10.21668 /$ health.risk/2019.1.08.eng

Read

online

\title{
ASSESSMENT OF POTENTIAL EPIDEMIC HAZARDS CAUSED BY COMBINED FOCI WITH BACTERIAL, VIRAL, AND RICKETSIAL INFECTIONS
}

\author{
E.V. Kuklev ${ }^{1}$, A.A.Kovalevskaya ${ }^{2}$, B.L. Agapov², S.A Scherbakova ${ }^{1}$ \\ ${ }^{1}$ Rospotrebnadzor's Russian Scientific and Research Anti-Plague Institute "Microbe", 46 Universitetskaya Str., \\ Saratov, 410005, Russian Federation \\ ${ }^{2}$ Rospotrebnadzor's Anti-plague Station in Astrakhan', 3 Kubanskaya str., Astrakhan', 414057, Russian Federation
}

The authors performed epidemiologic analysis on 2,008 case histories of dangerous feral nidal infections among Astrakhan' region population over the last 17 years. It allowed them to characterize basic categories of epidemiologic risk related to such infections under contemporary conditions and determine the most significant statistically authentic $(p<0.05)$ criteria for assessing potential epidemic hazards caused by autonomous and combined natural foci with bacterial, viral, or ricketsial nature in the north and northwestern Caspian Lowlands. The determined criteria included a number of morbid cases among people, quantity of infection carriers and agents (fleas, ticks, and mosquitoes), contamination of rodents and infection carriers, circulating strains virulence, presence of camels, results of immunologic research performed on infection carriers and agents, immune layer among risk groups that include people and animals, ambient temperature, and average annual precipitations. The authors took epidemiological data obtained by Rospoterbnadzor's Astrakhan' Anti-plague Station, Astrakhan' Regional Center for Hygiene and Epidemiology, and A.M. Nichoga's Regional Infectious Clinical Hospital; the data were collected over 2000-2017 and were given in primary medical documentation including forms No. 027/U, No. 058/U, No. 060/U), as well as in reports with results of epizootologic examinations accomplished on the examined territories. The authors applied score assessment to work out an algorithm for determining qualitative and quantitative parameters of hazards caused for people by natural foci of plague, tularemia, leptospirosis, Crimean hemorrhagic fever, West Nile fever, and Astrakhan's ricketsial fever. This technique allows to perform scientifically substantiated epidemiologic zoning of territories with foci and to differentiate necessary prevention activities both in combined and autonomous infectious diseases foci with simultaneous reduction in expenditure.

Key words: potential epidemic hazards, natural foci with bacterial, viral, and ricketsial infections.

Introduction. There has been sporadic morbidity with tularemia, leptospirosis, brucellosis, Crimean hemorrhagic fever (CHF) [1, 17, 18], West Nile fever (WNF) [1-4, 21], and Astrakhan ricketsial fever (ARF) [6, 9] registered on the northern and northwestern Caspian Lowlands territories which were enzootic as per plague. In some years there was group morbidity or outbreaks of certain diseases (Crimean hemorrhagic fever in 2005-2008, West Nile fiver in 1999) [3, 10-12, 18-20]. Viral and ricketsial infections should be given special attention.

Thus, morbidity with CHF in Astrakhan region was registered every year (excluding 2014). There were three peaks detected in the overall morbidity dynamics; they occurred in 2001-2002,
2005-2007, and 2010, and all of them were followed by a drastic decrease in morbidity with the disease. But still, there is a statistically authentic $(\mathrm{P}<0.05)$ trend for morbidity with CHF to decline.

On the contrary, morbidity with WNF varied from 7.3 per 100,000 population in Astrakhan region in 2005 to 0.1 in 2007; in 2016 it amounted to $2.7 \pm 1.2$ on average. A calculated trend that describes dynamics in morbidity with this infection in Astrakhan region indicates there is a slight decrease in it. However, a model of the 6th order polynomial approximation proves there is likely to be an outbreak of the disease in the nearest future.

Astrakhan ricketsial fever is a new infectious disease [1]. People with the infection

(C) Kuklev E.V., Kovalevskaya A.A., Agapov B.L., Scherbakova S.A, 2019

Evgeniy V. Kuklev - Doctor of Medical Sciences, Leading researcher (e-mail:Kouklev50@mail.ru; tel. +7 (845) 273-46-48; ORCID iD: 0000-0002-9425-7194)

Anastasiya A. Kovalevskaya - an epidemiologist at the Epidemiological Department also responsible for providing biological safety (e-mail: anastasiya_scorpion1986@mail.ru; tel.: +7 (851) 233-37-00; ORCID iD: 0000-0002-8953-8813).

Boris L. Agapov - Deputy Director responsible for epidemiologic work, temporarily acting as Director (e-mail: antichum@, astranet.ru; tel.: +7 (851) 233-37-00; ORCID iD: 0000-0001-5395-6688).

Svetlana A. Scherbakova - Doctor of Biological Sciences, Deputy Director responsible for scientific and anti-epidemic work (e-mail: rusrapi@microbe.ru; tel.: +7 (845) 226-21-31; ORCID iD: 0000-0003-1143-4069). 
were first detected in 1978 in Krasnoyarskiy distirct of Astrakhan region, and in subsequent years it was also registered in other districts of the region. In 1978-1981 32 morbid events were registered; there were 47 in 1982, and 82 in 1988 [21]. Over the last decades morbidity with ARL has been registered in all the administrative districts in Astrakhan region, excluding Chernoyarskiy district. The highest morbidity levels are detected in Privolzhskiy and Narimanovskiy districts (783.6 and 523.6 per 100,000 population respectively).

Specific areas in natural foci are apparently different as per their potential epidemic hazards; given that, it is advisable, on one hand, to reduce volumes of epizootologic research as it is the most expensive component in the whole set of epidemiologic surveillance; on the other hand, one cannot degrade safety for population groups that run elevated risks of infection. All the above mentioned underlies a differentiated approach to epizootologic monitoring over foci with different epidemiologic status $[6,13,14]$.

As preventive (anti-epidemic) activities aimed at eliminating hazardous infections are at present accomplished as per specific nosologies on various administrative territories in the RF regions, it is necessary to work out complex prevention plans for feral nidal infections taking into account occurrence of combined foci and results of epidemiologic zoning performed as per epidemic risk levels.

Our research goal was to work out a procedure for assessing potential economic hazards caused by autonomous and combined foci of bacterial, viral, and ricketsial infections; the procedure should be relevant for Astrakhan region.

Data and methods. The authors applied data collected by Astrakhan Anti-Plague Station, Rospotrebnadzor's Regional Office in Astrakhan, Astrakhan Center for Hygiene and Epidemiology, as well as results of epizootologic and epidemiologic research performed in the region.

We performed epidemiologic analysis of data on epidemic and epizootic activities occurring in autonomous natural foci of plague, tularemia, leptospirosis, Crimean hemorrhagic fever, West Nile fever, and Astrakhan ricketsial fever, detected in Astrakhan region; the data were collected over 2000-2016. Overall, we examined 2,008 case histories.

We applied score assessment in a modification developed by E.V. Kuklev [7, 8]. All the data were statistically processed with conventional techniques [16].

Results and discussion. In order to perform epidemiologic zoning in Astrakhan region and differentiate existing autonomous and combined natural foci of hazardous viral, bacterial, and ricketsial infections into separate areas as per their potential epidemic risk levels, we analyzed epizootic and epidemiologic status in natural foci of the examined infections over 2000-2016. Basing on the results of epidemiologic analysis performed on 2,008 case histories related to Astrakhan region population morbidity with hazardous feral nidal infections (plague, tularemia, leptospirosis, Crimean hemorrhagic fever, West Nile fever, Astrakhan ricketsial fever) detected in 2000-2016, we determined the most significant parameters (features) that quantitatively and qualitatively reflect specific epidemiologic peculiarities of the examined infections (Tables 1 and 2).

Our choice of these parameters is substantiated taking into account a direct statistically authentic correlation $(\mathrm{P}<0.05)$ between each such parameter and people catching the infections. This proposition is also confirmed by the results obtained in previous research and potential epidemic hazards calculated for various infections: hemorrhagic fever with nephrotic syndrome $(r=+0.76)[5]$, plague, cholera, malaria $(r>+0.6)$, arbovirus infections (CHF virus circulation value $=0.79)[8,18]$, virus hepatitis of B and C type $(r>+0.7)$ [15], and assessment of potential hazards related to mass events $(100 \%$ coincidence of qualitative and quantitative parameters of potential epidemic hazards (PEH) related to mass events) [14].

Score assessment combined with conventional variation statistics techniques turned out to be the most relevant technique for assessing different parameters.

We detected an entire assembly of features for each parameter and spotted out three gradations, high, average, and low one, depending on assembly size and confidence intervals. Each 
Table 1

Parameters of potential epidemic hazards caused by combined natural foci with bacterial infections and their scores

\begin{tabular}{|c|c|c|}
\hline Parameters of potential epidemic hazards caused by natural foci & $\begin{array}{c}\text { Parameter } \\
\text { symbol }\end{array}$ & $\begin{array}{l}\text { Maximum } \\
\text { score }\end{array}$ \\
\hline \multicolumn{3}{|l|}{ PARAMETERS COMMON FOR ALL NATURAL FOCI } \\
\hline Physical square of an area within a natural foci & $\mathrm{S}$ & 2 \\
\hline Population density (urban and rural) & $\mathrm{P}$ & 3 \\
\hline PLAGUE & & 15 \\
\hline Number of disease cases among people & A & 7 \\
\hline $\begin{array}{l}\text { Number of plague carriers (average over long-term period/current): primary } \\
\text { ones, secondary ones, in settlements }\end{array}$ & B & 1 \\
\hline Contamination of rodents with plague agent & $\mathrm{D}$ & 2 \\
\hline Results of immunologic research on animals (on $\mathrm{Ag}$ and $\mathrm{Ab}$ ) & $\mathrm{M}$ & 1 \\
\hline $\begin{array}{l}\text { Number of plague carriers (Abundance index for hair, holes, microbiotopes) } \\
\text { (average over long-term period/current): in houses, in open biotopes }\end{array}$ & $\mathrm{C}$ & 1 \\
\hline Contamination of fleas with plague agent & $\mathrm{E}$ & 1 \\
\hline Virulence of plague agent strains & $\mathrm{V}$ & 1 \\
\hline Presence of camels (private sector and public livestock) & $\mathrm{L}$ & 1 \\
\hline TULAREMIA & & 15 \\
\hline Number of disease cases among people & A & 7 \\
\hline Immune layers among risk groups & $\mathrm{K}$ & 1 \\
\hline $\begin{array}{l}\text { Number of tularemia carriers (average over long-term period/current): in open } \\
\text { biotopes, in closed biotopes }\end{array}$ & B & 1 \\
\hline Results of immunologic research on animals (on $\mathrm{Ag}$ and $\mathrm{Ab}$ ) & $\mathrm{M}$ & 1 \\
\hline $\begin{array}{l}\text { Number of ticks (average over long-term period/current): in open biotopes, } \\
\text { number of registered species }\end{array}$ & $\mathrm{C}$ & 1 \\
\hline Contamination of ticks with tularemia agent & $\mathrm{E}$ & 2 \\
\hline Contamination of rodents with tularemia agent & $\mathrm{D}$ & 2 \\
\hline LEPTOSPIROSIS & & 15 \\
\hline Number of disease cases among people & A & 7 \\
\hline $\begin{array}{l}\text { Number of leptospirosis carriers (average over long-term period/current) in } \\
\text { anthropurgic foci: rats, cattle, pigs, dogs }\end{array}$ & B & 2 \\
\hline Contamination of carriers with leptospirosis agents: rats, cattle, pigs, dogs & $\mathrm{D}$ & 4 \\
\hline Results of immunologic research on animals (on $\mathrm{Ag}$ and $\mathrm{Ab}$ ): rats, cattle, pigs, dogs & M & 2 \\
\hline
\end{tabular}

Table 2

Parameters of potential epidemic hazards caused by combined natural foci with viral and ricketsial infections and their scores

\begin{tabular}{|c|c|c|}
\hline Parameters of potential epidemic hazards caused by natural foci & $\begin{array}{c}\text { Parameter } \\
\text { symbol }\end{array}$ & $\begin{array}{l}\text { Maximum } \\
\text { score }\end{array}$ \\
\hline \multicolumn{3}{|c|}{ PARAMETERS COMMON FOR ALL NATURAL FOCI } \\
\hline Physical square of an area within a natural foci & $\mathrm{S}$ & 2 \\
\hline Population density (urban and rural) & $\mathrm{P}$ & 3 \\
\hline CRIMEAN HEMORRHAGIC FEVER & & 15 \\
\hline Number of disease cases among people & A & 7 \\
\hline $\begin{array}{l}\text { Natural and climatic conditions on a specific area: average temperature (Janu- } \\
\text { ary, July), } \\
\text { Average annual precipitation }\end{array}$ & $\begin{array}{l}\mathrm{T} \\
\mathrm{U}\end{array}$ & 2 \\
\hline Number of primary CHF virus carriers: D. marginatum ticks & $\mathrm{C}$ & 2 \\
\hline
\end{tabular}




\begin{tabular}{|c|c|c|}
\hline $\begin{array}{l}\text { Detection of CHF virus markers: ticks, small mammals, blood serum of farm } \\
\text { animals, human blood serum }\end{array}$ & M & 4 \\
\hline WEST NILE FEVER & & 15 \\
\hline Number of disease cases among people & $\mathrm{A}$ & 7 \\
\hline Sum of average daily temperature is higher than $+10^{\circ} \mathrm{C}$ & $\mathrm{T}$ & 2 \\
\hline $\begin{array}{l}\text { Number of primary WNF virus carriers (mosquitoes of Culex species): in open } \\
\text { biotopes, in closed biotopes }\end{array}$ & $\mathrm{D}$ & 3 \\
\hline $\begin{array}{l}\text { Detection of WNF virus markers: mosquitoes, ticks, wild waterfowl, farm wa- } \\
\text { terfowl, human blood serum }\end{array}$ & M & 3 \\
\hline ASTRAKHAN RICKETSIAL FEVER & & 15 \\
\hline Number of disease cases among people & A & 7 \\
\hline $\begin{array}{l}\text { Number of primary rickettsia ticks carriers: in open biotopes, in settlements } \\
\text { on cats and dogs }\end{array}$ & $\mathrm{C}$ & 4 \\
\hline Detection of ARF virus markers: ticks, human blood serum & M & 4 \\
\hline
\end{tabular}

gradation corresponded to a quantitative score given to each parameter; 14-20 scores corresponded to high gradation, 7-13, average one, and less than 7 scores meant gradation was low. This distribution of scores is a sum of scores given to criteria common for all feral nidal infections (5 scores) and a sum of scores which are specific for this or that infection (15 scores maximum).

For example, potential epidemic hazard caused by a natural plague focus is calculated as follows:

$$
\begin{aligned}
& \Pi \ni \mathrm{O}_{1}=S+P+A+B+C+D+E+M+L+V= \\
& =2+1+0+0,5+0,5+0+1+0+1+0,5=6,5,
\end{aligned}
$$

where ПЭО1 is a parameter that describes potential epidemic hazard existing in a natural plague focus, $S$ is a physical square of an area within a natural focus, $\mathrm{P}$ is population density (urban and rural), $\mathrm{A}$ is a number of disease cases among people, $\mathrm{B}$ is a number of plague carriers, $\mathrm{C}$ is a number of plague agents, $\mathrm{D}$ is contamination of rodents, $\mathrm{E}$ is contamination of fleas, $\mathrm{M}$ is a results obtained in immunologic research, $\mathrm{L}$ is presence of camels, $\mathrm{V}$ is virulence of strains (for white mice or guinea pigs).

Calculated potential epidemic hazard of an area within a natural plague focus amounts to 6.5 scores and it means the hazard is low.

Parameters of potential epidemic hazards existing on territories of combined natural foci were calculated as a sum of values obtained for potential epidemic hazards as per each separate infection divided by a number of these infections:

$$
\begin{gathered}
\mathrm{PEH}=\left(\mathrm{PEH}_{1}+\mathrm{PEH}_{2}+\mathrm{PEH}_{3}+\right. \\
\left.+\mathrm{PEH}_{4}+\mathrm{PEH}_{5}+\mathrm{PEH}_{6}\right): 6,
\end{gathered}
$$

where $\mathrm{PEH}$ is a potential epidemic hazard existing in a combined natural focus, $\mathrm{PEH}_{1}$ is a potential epidemic hazard of a natural plague focus; $\mathrm{PEH}_{2}$, tularemia; $\mathrm{PEH}_{3}$, leptospirosis; $\mathrm{PEH}_{4}$, Crimean hemorrhagic fever; $\mathrm{PEH}_{5}$, West Nile fever; $\mathrm{PEH}_{6}$, Astrakhan ricketsial fever.

Conclusion. We proposed the most statistically significant criteria for assessing potential epidemic hazards existing in autonomous and combined natural foci of bacterial, viral, and ricketsial infections (plague, tularemia, leptospirosis, Crimean hemorrhagic fever, West Nile fever, and Astrakhan ricketsial fever) in northwestern Caspian Lowlands. We have developed an algorithm based on score assessment for qualitative and quantitative estimation of potential epidemic hazards caused by such natural foci. If the proposed procedure is implemented, it will allow to perform scientifically substantiated epidemiologic zoning of a natural focus territory and to differentiate prevention activities thus reducing expenditure. It is recommended to apply this approach when accomplishing epidemiologic surveillance over feral nidal infections in northwestern Caspian Lowlands.

Funding. The research was not granted any sponsor support.

Conflict of interests. The authors state there is no any conflict of interests. 


\section{References}

1. Androsova S.V., Rogatkin A.K. Izuchenie ekologii arbovirusov i rasprostranenie prirodno-ochagovykh boleznei na territorii Astrakhanskoi oblasti. [Studies of the ecology of arboviruses and dissemination of natural-focal infections in the territory of the Astrakhan region]. Astrakhan', 1996, 32 p. (in Russian).

2. Butenko A.M., Kovtunov A.I., Dzharkenov A.F., Zlobina L.V., Grishanova A.P., Azaryan A.R., Larichev V.F., Shishkina E.O. [et al.]. Epidemiologicheskaya kharakteristika likhoradki Zapadnogo Nila $\mathrm{v}$ Astrakhanskoi oblasti [Epidemiological characteristics of West Nile fever in the Astrakhan Region]. Voprosy virusologii, 2001, no. 3, pp. 34-35 (in Russian).

3. Zhukov A.N., Filippov A.G., Krasnova E.N. Epidemiya likhoradki Zapadnogo Nila v Volgogradskoi oblasti [West Nile fever epidemic in the Volgograd region]. Zdorov'e naseleniya i sreda obitaniya, 2000, vol. 92, no. 11, pp. 9-10 (in Russian).

4. Zhukova L.I., Rafeenko G.K., Gorodin V.N., Vanyukov A.A. Kliniko-epidemiologicheskaya kharakteristika likhoradki Zapadnogo Nila v Krasnodarskom krae [Clinical-epidemiological characteristics of West Nile fever in the Krasnodar Territory] Zhurnal mikrobiologii, epidemiologii i immunobiologii, 2016, no. 2, pp. 74-80 (in Russian).

5. Kresova Yu. A., Garanina S.B., Kazakova L.V., Kuklev E.V., Safronov V.A. Sochetannye ochagi aktual'nykh dlya Saratovskoi oblasti prirodno-ochagovykh infektsionnykh boleznei [Combined foci of relevant for the Saratov Region natural-focal infectious diseases]. Zdorov'e naseleniya i sreda obitaniya, 2014, vol. 255, no. 6, pp. 30-32 (in Russian).

6. Kolobukhina L.V., L'vov S.D. Arbovirusy serogruppy kaliforniiskogo entsefalita v Rossii i ikh znachenie $\mathrm{v}$ infektsionnoi patologii [Arboviruses of California encephalitis serogroup in Russia and their role in infectious pathology]. Vestnik Rossiiskoi Akademii meditsinskikh nauk, 2011, no. 5, pp. 41-45 (in Russian).

7. Kuklev E.V., Kokushkin A.M., Kutyrev V.V. Kolichestvennaya otsenka velichiny epidemicheskogo potentsiala prirodnykh ochagov chumy i optimizatsiya epidemiologicheskogo nadzora za etoi infektsiei [Quantitative assessment of epidemic potential value of natural plague foci and optimization of epidemiological surveillance over the infection]. Epidemiologiya $i$ infektsionnye bolezni, 2001, no. 5, pp. 10-13 (in Russian).

8. Kuklev E.V., Kovalevskaya A.A., Kovtunov A.I. Kriterii otsenki potentsial'noi epidemicheskoi opasnosti sochetannykh prirodnykh ochagov bakterial'nykh i virusnykh infektsii [Criteria for the assessment of potential epidemic hazard of combined natural foci of bacterial and viral infections]. Materialy XIII Mezhgosudarstvennoi nauchno-prakticheskoi konferentsii, 2016, Saratov, pp. 136-137 (in Russian).

9. L'vov D.K., Klimenko S.M., Gaidamovich S.Ya. Arbovirusy i arbovirusnye infektsii [Arboviruses and arboviral infections]. Moscow, 1989, 335 p. (in Russian).

10. L'vov D.K., Pisarev V.B., Petrov V.A., Grigor'eva N.V. Likhoradka Zapadnogo Nila: po materialam vspyshek v Volgogradskoi oblasti v 1999-2002 gg. [West Nile fever: a case study of theoutbreaks in the Volgograd Region in 1999-2002]. Volgograd, 2004, 102 p. (in Russian).

11. Maleev V.V., Galimzanov Kh.M., Butenko A.M., Cherenov I.V. Krymskaya gemorragicheskaya likhoradka [Crimean Congo hemorrhagic fever]. Moscow, Astrakhan' Publ., 2003, 118 p. (in Russian).

12. Onishchenko G.G., Efremenko V.I., Beier A.P. Krymskaya gemorragicheskaya likhoradka [Crimean Congo hemorrhagic fever]. Moscow, Vserossiiskii uchebno-nauchno-metodicheskii tsentr po nepreryvnomu meditsinskomu i farmatsevticheskomu obrazovaniyu Publ., 2005, 269 p. (in Russian).

13. Onishchenko G.G., Kutyrev V.V., Krivulya S.D. [et al.]. Strategiya bor'by s infektsionnymi boleznyami i sanitarnaya okhrana territorii v sovremennykh usloviyakh [Strategy to counter infectious diseases and sanitary protection of the territory under current conditions]. Problemy osobo opasnykh infektsii, Saratov, 2006, vol. 2, no. 92, 2010, pp. 5-9 (in Russian).

14. Onishchenko G.G. Patyashina M.A., Udovichenko S.K. [et al.]. Kolichestvennaya otsenka potentsial'noi epidemicheskoi opasnosti massovykh meropriyatii s mezhdunarodnym uchastiem ee aprobatsiya v usloviyakh Universiady-2013 [Quantitative Assessment of Potential Epidemic Hazard of Mass Events with International Participation and Methodology Approbation in the Context of Universiade2013]. Problemy osobo opasnykh infektsii, Saratov, 2015, pp. 5-9 (in Russian).

15. Pichugina L.M., Kologorov A.I., Danilov A.N., Kozhanova O.I. Epidemiologicheskie osobennosti ostrogo gepatita $\mathrm{v}$ Saratovskoi oblasti v sovremennykh usloviyakh [Epidemiological peculiarities of severe hepatitis in the Saratov Region under current conditions]. Problemy osobo opasnykh infektsii, Saratov, 2010, vol. 3, no. 105, pp. 25-27 (in Russian). 
16. Plokhinskii N.A. Biometriya [Biometrics]. Moscow, 1970, 336 p. (in Russian).

17. Smirnova S.E., Sedova A.G., Zimina Yu.V., Karavanov A.S. O sluchayakh Krymskoi-Kongo gemorragicheskoi likhoradki v Astrakhanskoi oblasti [Concerning the cases of Crimean Congo hemorrhagic fever in the Astrakhan Region]. Voprosy virusologii, 1990, no. 3, pp. 228-231 (in Russian).

18. Smirnova S.E. Smirnova S.E. Krymskaya-Kongo gemorragicheskaya likhoradka (etiologiya, epidemiologiya, laboratornaya diagnostika) [Crimean Congo hemorrhagic fever (etiology, epidemiology, laboratory diagnostics)]. Moscow, Akademiya truda i sotsial'nykh otnoshenii Publ., 2007, 302 p. (in Russian).

19. Tarasevich I.V. Astrakhanskaya pyatnistaya likhoradka. Moscow, Meditsina Publ., 2002, 171 p. (in Russian).

20. Ugleva S.V., Burkin A.V., Shabalina S.V. Sovremennaya epidemiologo-entomologicheskaya otsenka transmissivnykh likhoradok, dominiruyushchikh na territorii Astrakhanskoi oblasti [Current epidemiological-entomological assessment of transmissible fevers dominant in the territory of the Astrakhan Region]. Epidemiologiya i vaktsinoprofilaktika, 2011, no. 4, pp. 5-11.

21. Gratz N.G. Emerging and resurging vector-borne diseases. Annual Review Entomology, 1999, vol. 44, pp. 51-75.

22. Lvov D.K., Butenko A.M., Gromashevsky V.L., Kovtunov A.I., Prilipov A.G., Kinney R., Aristova V.A., Dzharkenov A.F. [et al.]. West Nile and other zoonotic viruses as examples of emergingreemerging situations in Russia. Archives of virology. Supplementum, 2004, 18, pp. 85-96.

Kuklev E.V., Kovalevskaya A.A., Agapov B.L., Scherbakova S.A. Assessment of potential epidemic hazards caused by combined foci with bacterial, viral, and ricketsial infections. Health Risk Analysis, 2019, no. 1, pp. 78-83. DOI: 10.21668/health.risk/2019.1.08.eng

Received: 01.11.2018

Accepted: 26.01 .2019

Published: 30.03.2019 
UDC 614.2: 614.484

DOI: 10.21668/health.risk/2019.1.09.eng

Read

\title{
DEVELOPING METHODICAL APPROACHES TO MANAGING RISKS OF AIRBORNE INFECTIONS WITH AEROSOL CONTAGION
}

\author{
N.V. Shestopalov ${ }^{1,3}$, A. Yu. Skopin ${ }^{1,2}$, L.S. Fedorova ${ }^{1}$, T.V. Gololobova ${ }^{1,3}$ \\ ${ }^{1}$ Science Research Institute for Disinfectology of the Federal Service for Surveillance over Consumer Rights \\ Protection and Human Well-being, 18 Nauchniy lane, Moscow, 117246, Russian Federation \\ ${ }^{2}$ I.M. Sechenov's First Moscow State Medical University, bld. 2, 8 Trubetskaya Str., Moscow, 119991, \\ Russian Federation \\ Russian Medical Academy for Continuing Professional Education of the RF Public Healthcare Ministry, bld. 1, \\ 2/1 Barrikadnaya Str., Moscow, 125993, Russian Federation
}

A promising way to prevent spread of airborne infections with aerosol contagion and to reduce risks of healthcareassociated infections (HAI) is to preserve clean air inside premises (including medical organizations) via performing activities aimed at disinfecting air, ventilation and air-conditioning systems and via switching to up-to-date ecologically friendly disinfectants and their rotation.

Epidemiological hazards for patients and medical personnel in medical organizations are caused by pathogenic and opportunistic pathogenic microorganisms that can be found in the air inside premises and on various surfaces; such microorganisms are bacteria in their vegetative form (including tuberculosis agents), viruses, fungi that cause candidosis and dermatophytes, mold fungi, spore bacteria.

Aerosol disinfection is a well proven technique for treating the air inside premises in order to disinfect it and to reduce risks of infections spread; this technique involves transforming a disinfectant into a fine-disperse state with a specialized spraying device so that an aerosol is introduced into the air inside a premise.

To work out efficient air disinfection regimes that involve application of relevant equipment and disinfectants, it is necessary to apply such techniques and conditions that would secure the most efficient application of aerosol disinfection in practical conditions.

The authors have outlined basic organizational and methodical approaches to an objective assessment of how efficient and how safe aerosol disinfection technique is when it is applied in different premises, including medical organizations.

Key words: air decontamination, air disinfection, aerosol disinfection technique, Assessment of disinfectants efficiency, disinfectant aerosol, examination of decontamination efficiency, airborne infections with aerosol contagion, aerosol chamber.

At present morbidity with respiratory infections still remains high in Russia. In spite of more and more activities aimed at preventing infections, there are considerable risks of prevalence and growing morbidity related to airborne infections with aerosol contagion including healthcare-associated ones (HAI) [1-7]. In 2017, just like in previous years, acute respiratory infections (ARI) took the first place among infec-

tious and parasitic diseases in the Russian Federation; they predominantly occurred in the upper respiratory tracts in multiple or unspecified locations. Over the last 6 years (2012-2013) morbidity with ARI has grown by $9.3 \%$ in the Russian Federation. In 2014 there was a slight decrease in it down to $19,506.00$ per 100 thousand people but then a gradual increase followed up to its previous values and even above [8].

(C) Shestopalov N.V., Skopin A. Yu., Fedorova L.S., Gololobova T.V., 2019

Nikolay V. Shestopalov - M.D., Professor, Head, Professor at the Department for Organization of the State Sanitary and Epidemiological Service (e-mail: shestopalov.nv@gmail.com; tel.: +7 (495) 332-01-01; ORCID: https://orcid.org/0000-0002-9973-3508).

Anton Y. Skopin - Ph.D. of Medical Sciences, Associate Professor, Head of the Laboratory dealing with sterilization issues, Associate Professor at the Department for General Hygiene (e-mail: auskopin@yandex.ru; tel.: +7 (495) 332-01-65; ORCID: https://orcid.org/0000-0001-7711-9489).

Lyudmila S. Fedorova - M.D., Professor, Head of the laboratory dealing with disinfection issues (e-mail: fedorova-ls@ yandex.ru; tel.: +7 (495) 332-01-60; ORCID: https://orcid.org/0000-0001-2663-0273).

Tatiana V. Gololobova - M.D., Deputy Head of the Science Research Institute for Disinfectology, Professor at the Department of tropical, parasitic diseases and disinfection care (e-mail: 1915544@mail.ru; tel.: +7 (495) 332-01-15; ORCID: https://orcid.org/0000-0001-9033-5223). 
In $201721.66 \%$ of the overall country population had ARI, 79\% of them being children younger than 17. More than 31.77 million ARI cases were registered in Russia, and morbidity amounted to $21,664.01$ per 100 thousand people. Children under 17 prevail among patients with ARI, with their share accounting for $73.16 \%$ in 2017 [8].

Air as a natural aerosol is a perfect medium that makes for contagion of respiratory infections [9]. Vast quantity of microorganisms in any room occur in a dust environment and tend to accumulate in it, concentrate in places that are hard-to-get; these microorganisms move together with air flows thus creating potential infection foci [10-12].

Dust particles can bear up to $95 \%$ of all microorganisms that occur in the indoor air. Since some infectious agents are rather resistant, various places in the environment, especially indoors, that are hard-to-get become massively infected due to dust accumulating in them [13].

Moreover, surfaces that can be found indoors usually have a lot of defects, such as pockets, cracks, capillaries and so called crypts (small craters). Any surface even if it seems ideally smooth has a lot of crypts which can be seen only under a high magnification; microorganisms are able to survive any chemical attack in these tiny craters and then reproduce themselves, return onto a surface and make a population grow.

All the above mentioned causes and elevates risks that infectious agents penetrate a body and makes it especially pressing to create and improve objective techniques for assessing efficiency of disinfectants, equipment, and technologies applied for air disinfection.

It is vital to find such a treatment technology that can guarantee disinfection in all hard-to-get places as it will eventually allow to prevent negative outcomes that microbe contamination in the indoor air may have, to reduce risks of biological emergencies including those that can possibly occur in overcrowded places $[14,15]$.

Aerosol disinfection is one of such technologies; it involves transferring a liquid disinfectant into a fine-disperse state and its introduction into the air inside a room. An aerosol fills the overall space and deposits on surfaces of objects (walls, floor, equipment and devices). Aerosol drops partially evaporate and thus penetrate all the cracks, holes, and notches; it makes for greater and more efficient interaction between a disinfectant and a microbe cell resulting in its death [16].

An ordinary drop which is not created with technological equipment can't penetrate tiny surface defects due to osmotic laws; it can only jam them for some time. Aerosol particles with ultra-small sizes $(5-35 \mu \mathrm{m})$ can penetrate anywhere and it, due to adhesion and heat precipitation, allows them to fill all tiny surface defects thus covering this surface evenly and completely; they can also treat an air space where microorganisms migrate due to convection flows $[12,17]$.

Aerosol disinfection is well known to be successfully applied for disinfecting air and surfaces in medical and public organizations all over the world. Overall requirements to choice on equipment, chemical disinfectants and treatment technologies for air disinfection in medical organizations via aerosol spraying are fixed in the Methodical guidelines on aerosol disinfection in medical organizations ${ }^{1}$. However, the Guidelines don't fix any requirements to conditions and a procedure for an examination of equipment and substances which are to be applied for aerosol disinfection; and surely, such examinations are necessary for working out efficient disinfection modes.

It is vital to obtain objective assessment whether aerosol disinfection is efficient and

\footnotetext{
${ }^{1}$ Methodical guidelines on aerosol disinfection in medical organizations: Methodical guidelines MR 3.5.1.0103-15. M.: The Federal Service for Surveillance over Consumer Rights Protection and Human Well-being, 2015. - 11 p.
} 
safe when applied inside various buildings and rooms, including medical organizations; to do that, the Test Laboratory Center at the Rospotrebnadzor's Scientific Research Institute of Disinfectology organizes and performs laboratory-experimental examinations aimed at determining efficiency and safety of disinfectants and specific equipment for spraying them (aerosols generators) as well as any other equipment used for disinfecting air and surfaces inside.

It should be noted that any study on efficiency of air disinfections under laboratory conditions is rather labor-consuming, both in terms of its organization and methodical support, and it requires strict adherence to requirements fixed in various regulatory and legal documents and applied to laboratory rooms, equipment, and working procedures for handling microorganisms aerosols and chemicals. The existing experience related to aerosol disinfectants examinations indicates that efficiency of such substances to a certain extent depends on several factors, such as chemical structure of a substance (an active ingredient and its concentration in a working solution of a substance), what quantity of a substance is spent per a unit volume and area in a room, aerosol dispersity, duration of a disinfection cycle and a number of cycles required, conditions for applying a substance (preventive disinfection, or focal disinfection applied to prevent different infections taking into account an infectious agent), persistence of an aerosol in the air.

Our research goal was to substantiate and implement complex methodical approaches to organizing and conducting examinations on safety and efficiency of disinfectants aimed at solving tasks related to managing health risks.

Data and methods. We applied microorganisms which were significant from a sanitary point of view (Staphylococcusaureus, strain 906, ATCC 6538-P) as our test ones; they were applied to artificially contaminate air so that it became possible to examine efficiency of disinfectants which were sprayed as an aerosol as well as efficiency of disinfecting equipment. We took Mycobacteriumterrae, DSM 43227, to assess tuberculocidal effects produced by disinfectants. These microorganisms belong to III-IV pathogenicity category as per a classification used in the RF (SER 1.3.2322-08 "Safe handling of microorganisms belonging to III-IV pathogenicity (hazard) category and parasitic pathogens" ${ }^{2}$, which is equivalent to the first pathogenicity category as per World Health Organization classification. It to a larger extent determines specificity and scope of requirements to rooms, equipment, and working procedures for handling such microorganisms.

The research was accomplished in conformity with sanitary-epidemiologic rules SER 1.3.2322-08 "Safe handling of microorganisms belonging to III-IV pathogenicity (hazard) category and parasitic pathogens". There is a great variety of existing disinfecting devices used for creating aerosols with different technical and operating features as well as parameters that determine efficiency of air disinfection modes. Therefore, to examine efficiency and safety of such equipment, we need to create conditions that are as close to its practical application as is only possible. Besides, functional peculiarities of various aerosol generators, namely their capability to treat rooms with different volumes, made it necessary to construct several chambers with different volumes to test various pieces of equipment depending on their power and functions.

The task was to examine efficiency of disinfectants (including aerosol tanks) aimed at disinfecting surfaces in a closed room with a limited volume (for example, inside a car

\footnotetext{
${ }^{2}$ Safe handling of microorganisms belonging to III-IV pathogenicity (hazard) category and parasitic pathogens: Sanitary rules SR 1.3.2322-08. - M.: Rospotrebnadzor's Federal center for Hygiene and Epidemiology, 2009. - 75 p.
} 
cabin). To solve it, we applied an aerosol chamber with its volume equal to $1 \mathrm{~m}^{3}$, which was actually a confined box belonging to the III biological safety category; such a box provides protection for a researcher, a product and an environment. The chamber was equipped with an exhaust ventilation driven mechanically via a rigid air duct. It had HEPAfilters belonging to $\mathrm{H} 14$ category for fine air purification as well as necessary operating holes for air inflow under pressure in order to create microorganisms aerosol and subsequent air sampling to assess how efficient air disinfection was (Figure 1).

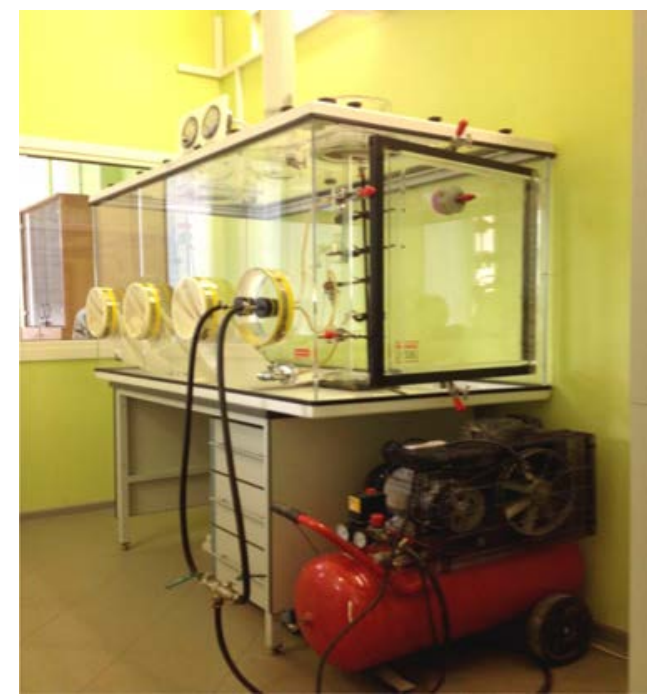

Figure 1. The aerosol chamber for examining efficiency of disinfecting aerosols

Our goal was to examine efficiency of disinfecting equipment applied to disinfect air in rooms with great volumes; to do that, we used room-chambers with their volumes up to $120 \mathrm{~m}^{3}$, specifically equipped with technical devices necessary for handling microorganisms belonging to III-IV pathogenicity category. A room-chamber used for the above-mentioned purposes with its volume being $120 \mathrm{~m}^{3}$ is a box which can be hermetically sealed and which is equipped with a mechanic supply-and-exhaust ventilation system with HEPA-filters belonging to $\mathrm{H} 14$ category for fine air purification installed both at an air supply point and an air exhaust one. The chamber inside is finished with specific covering materials which can withstand systematic treatment with disinfecting aerosols containing aggressive active ingredients. Open bactericidal irradiators are installed along the perimeter of the chamber which are applied to disinfect working volume air after experimental work with microorganisms is over. Safety for a researcher was provided with an obligatory kit for individual skin protection (protective overalls, rubber gloves, a cap) and respiratory organs protection (respirators or masks), first aid means, as well as alarm system buttons inside the box and in the forebox with the light and sound alarm system being brought out into the corridor (Figure 2).

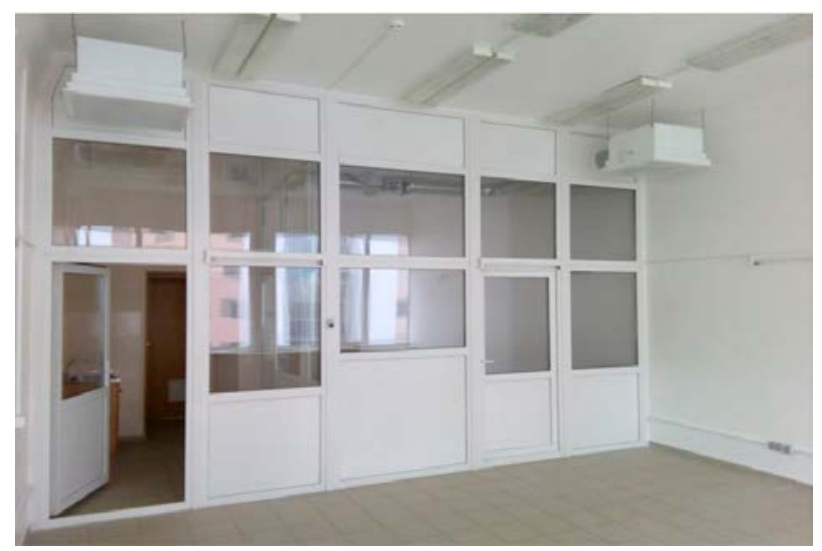

Figure 2. The chamber for examining efficiency of disinfecting aerosols

Another task was to determine bactericidal doses of impulse ultraviolet irradiation in a continuous spectrum that could provide 90-99.99\% efficiency when disinfecting air and surfaces contaminated with $S$. aureus bacteria [18]; to solve it, we applied specialized rooms in order to assess efficiency of disinfectants and disinfection equipment.

Research on efficiency of air disinfection with an aerosol generator involved creating a microbe suspension that was evenly distributed over the overall volume of a room with a ventilator. Preliminary series of experiments confirmed that contamination with an air suspension was stable during the whole experiment. Initial air contamination amounted to $1.46-4.80 \times 10^{5} \mathrm{CFU} / \mathrm{m}^{3}$. Air 
samples were taken with an aspirator that was pumping air through Drexel bottles filled with sterile tap water; the water was then evenly applied on Petri dishes and poured over with $10 \mathrm{ml}$ of meat-peptone agar which had been previously melted and then cooled down to $45{ }^{\circ} \mathrm{C}$. The results were estimated after 24-48-hour incubation under $37 \pm 1^{\circ} \mathrm{C}$. The same measurements obtained from air which had not been irradiated with impulse ultraviolet flows were used as control samples.

An impulse ultraviolet irradiation generator was put in the center of a chamber with its overall volume being equal to about $30 \mathrm{~m}^{3}$ (length equal to $3.1 \mathrm{~m}$; width, $2.4 \mathrm{~m}$; height, $4.0 \mathrm{~m}$ ) and switched on an irradiation mode from $1 \mathrm{~min} 31 \mathrm{sec}$ to $5 \mathrm{~min} 6 \mathrm{sec}$ [18].

When examining how efficient disinfection was in case of surfaces, we applied test microorganisms on the following materials: plastic (disposable Petri dishes with their diameter being equal to $85 \mathrm{~mm}$ ), metal (metal plates sized $50 \times 50 \mathrm{~mm}$, made of stainless steel), and tile (tile plates sized $50 \times 50 \mathrm{~mm}$ ).

We additionally applied $40 \%$ inactivated serum on a preliminary contaminated plastic surface to imitate its further organic contamination; it was done to examine influence exerted on efficiency of disinfection in case of organic contamination on irradiated surfaces.

All examined test-objects were irradiated with impulse ultraviolet irradiation from 2-meter distance. The generator was placed in such a way that allowed to exclude any influence exerted by a reflecting surface on bactericidal flow value on an irradiated surface (Figure 3).

Test surfaces were contaminated with a suspension, its initial contamination being equal up to $2.0 \times 10^{7} \mathrm{CFU} / \mathrm{cm}^{2} .0 .25 \mathrm{ml}$ of the suspension were put on samples surfaces with a micro-pipette and then evenly spread with a spatula and dried in a thermostat. Average microorganisms quantity on control plastic samples (which hadn't been irradiated) amounted to $1.0 \times 10^{6} \mathrm{CFU} / \mathrm{cm}^{2}$; metal

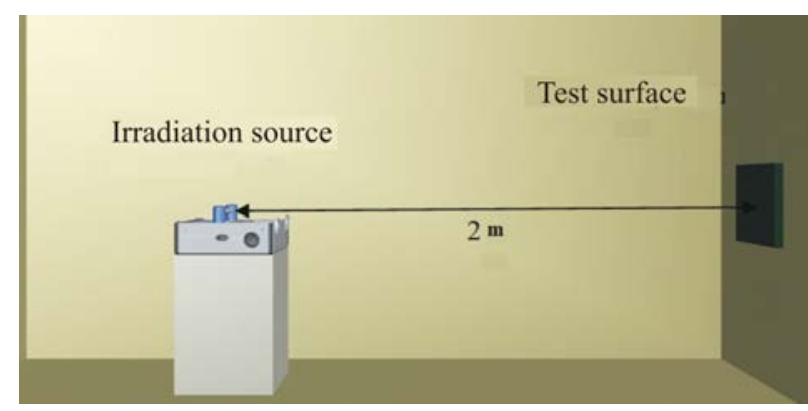

Figure 3. A scheme showing disinfection of test surfaces contaminated with S. aureus, with an impulse ultraviolet irradiation generator [18]

samples, $3.7 \times 10^{5} \mathrm{CFU} / \mathrm{cm}^{2}$; tile samples, $2.77 \times 10^{4} \mathrm{CFU} / \mathrm{cm}^{2}$. The obtained test-samples were exposed to ultraviolet irradiation for a period from 1 to 32 minutes. After the test was over, $10 \mathrm{ml}$ of sterile water were put into irradiated and control plastic samples (disposable Petri dishes), microbe cells were washed off surfaces with a spatula and evenly distributed in washout liquid. Then $10 \mathrm{ml}$ of meat-peptone agar which had been previously melted and then cooled down to $45^{\circ} \mathrm{C}$ were poured into Petri dishes. We examined two groups of control surfaces. Microorganisms were washed off the surfaces in the first group before the experiment started (before the suspension was dried a little); in the second group, after the experiment (3 hours after). Overall microorganisms quantity in washouts from the control surfaces was taken as an average before and after the experiment. All the experiments were repeated three times.

Results and discussion. Table 1 contains the results of our research on efficiency of disinfecting air contaminated with $S$. aureus in a specialized chamber with an impulse ultraviolet irradiation generator.

Volume bactericidal doses that can disinfect air with $90 \%$ efficiency are equal to $14 \mathrm{~J} / \mathrm{m}^{3}$, and with $99.9 \%, 47.5 \mathrm{~J} / \mathrm{m}^{3}$. $100 \%$ disinfection efficiency is reached after an exposure that lasts for 5 minutes 6 seconds.

We examined efficiency of disinfecting plastic test-objects with impulse ultraviolet irradiation in a continuous spectrum with disposable Petri dishes in tow series of experiments (Figure 4). 
Table 1

Efficiency of disinfecting air contaminated with S.aureus with an impulse ultraviolet irradiation generator [18]

\begin{tabular}{|c|c|c|c|c|c|}
\hline $\begin{array}{c}\text { Volume } \\
\text { of an } \\
\text { experi- } \\
\text { mental } \\
\text { box, } \mathrm{m}^{3}\end{array}$ & $\begin{array}{c}\text { Irradia- } \\
\text { tion } \\
\text { period }\end{array}$ & $\begin{array}{c}\text { Control, } \\
\text { CFU } / \mathrm{m}^{3}\end{array}$ & $\begin{array}{c}\text { Test, } \\
\text { CFU } / \mathrm{m}^{3}\end{array}$ & $\%$ & $\mathrm{l}$ \\
\cline { 4 - 7 } & $\begin{array}{c}5 \mathrm{~min} \\
6 \mathrm{sec}\end{array}$ & $4.8 \times 10^{5}$ & 0 & 100.00 & 5.6 \\
\cline { 2 - 7 } 30 & $\begin{array}{c}3 \mathrm{~min} \\
3 \mathrm{sec}\end{array}$ & $1.46 \times 10^{5}$ & 80 & 99.95 & 3.2 \\
\cline { 2 - 7 } & $\begin{array}{c}1 \mathrm{~min} \\
31 \mathrm{sec}\end{array}$ & $1.63 \times 10^{5}$ & $2.4 \times 10^{3}$ & 98.50 & 1.8 \\
\hline
\end{tabular}

Figure 4 represents a survival curve built up after two series of experiments taking into account all the previous research [18]. The survival curve is a typical 2-component one. $99.99 \%$ disinfection efficiency is reached even after 1-minute exposure to irradiation from a 2-meter distance.

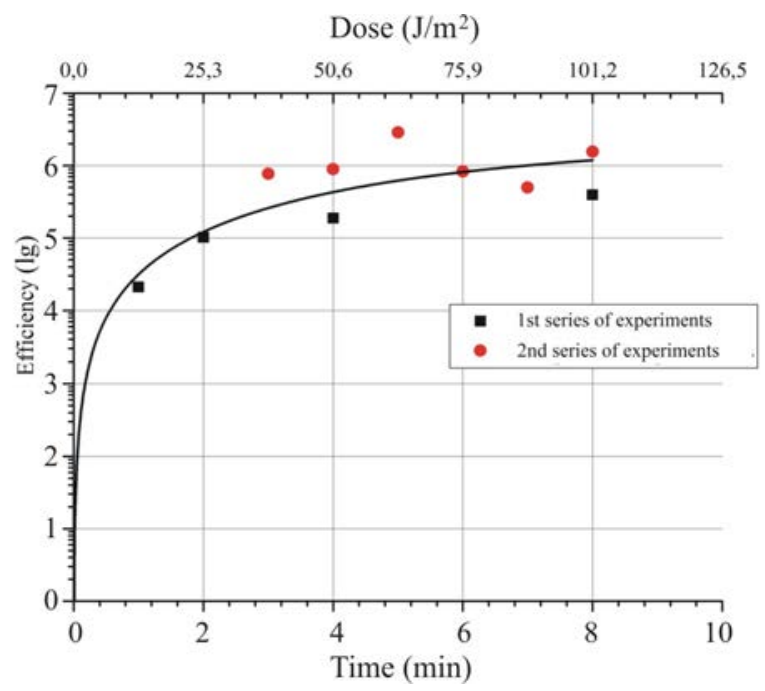

Figure 4. Efficiency of disinfections applied on plastic test-objects under various exposure to impulse ultraviolet irradiation

Figure 5 shows the results of research on influence exerted by a surface material and occurrence of organic contaminants on disinfection efficiency [18]. The research revealed that when test-objects were exposed to 2-minute irradiation, disinfection efficiency was not less than $99.99 \%$ on all examined surfaces or, in other words, it corresponded to an efficiency criterion fixed for the process. Disinfection was the most efficient on plastic and tile test-objects, and the lest efficient on metal ones. Biological contamination (biological burden) on a plastic surface doesn't have any substantial influence on attainable efficiency. The discrepancy between disinfection efficiency for plastic surfaces with biological burden and without it doesn't exceed 10 minutes under any exposure (from 2 to 8 minutes).

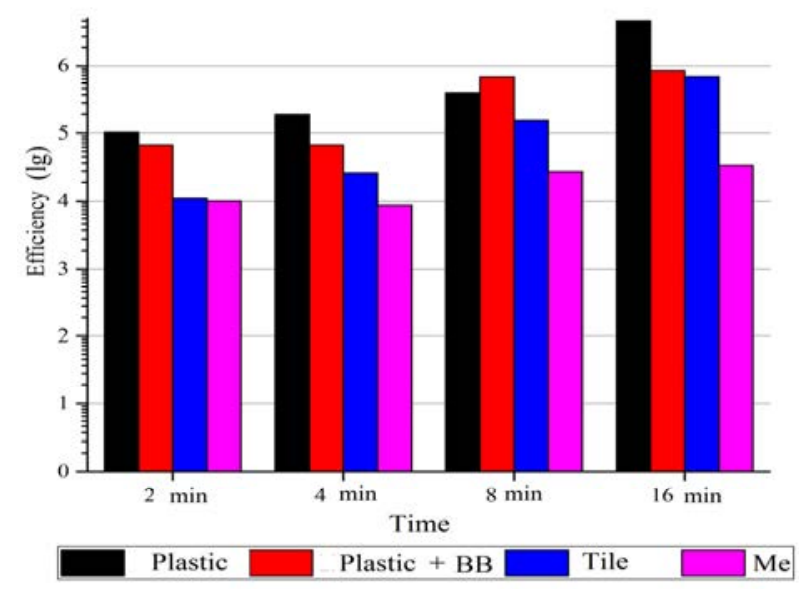

Figure 5. Influence exerted by a surface material and organic burden on efficiency of disinfection with impulse ultraviolet irradiation

As regards examining efficiency of chemical aerosol disinfectants, the greatest efficiency in terms of surfaces treatment was revealed for substances based on hydrogen peroxide with various additives, chlorine dioxide, and cation surface-active substances, and it is well in line with previously obtained data [19]. Substances were discharged in quantities within $10-50 \mathrm{ml} / \mathrm{m}^{3}$, disinfection exposure lasted from 60 to 240 minutes, aerosol dispersity varied from 5 to $30 \mu \mathrm{m}$ ("dried" and "moistened" spray). We should note that if a substance is discharged in greater quantities or exposure lasts longer, the efficiency also grows; but if aerosol dispersity and active ingredient concentration in a working solution go up, it doesn't necessarily lead to a positive outcome. An aerosol reached its maximum efficiency when particles size was 10-20 $\mu \mathrm{m}$ ("moistened" spray) for most examined substances. 
Softer modes are more efficient for air disinfection (both in terms of substance discharge and exposure duration), but surfaces disinfection requires harder ones; it is due to different physical and chemical interaction between disinfectant aerosols and microorganisms in the air and on surfaces.

Taking into account multi-factor impacts exerted by parameters determining disinfection efficiency in a laboratory on an actual disinfection taking place in practical conditions, and bearing in mind, that efficiency of such activities is the most important epidemiologically in rooms inside medical organizations ${ }^{3}$ that belong to A class of purity (the purest ones), we should make an environment inside a chamber for examining how efficient aerosol disinfection is as close to that existing in real life as its only possible.

When we model an environment inside a chamber and equip it with relevant pieces of furniture or medical devices, it allows to calculate standards for disinfectant discharge properly, taking into account not only a volume of a room but also total surfaces square which becomes greater due to objects placed inside it. The latter should be calculated when creating efficient modes for surfaces disinfection with aerosols. Besides, if we use real model objects made of the same materials as medical furniture and devices, it allows us to achieve high precision in creating efficient modes for surfaces disinfection in rooms inside medical organizations that belong to A class of purity (the purest ones). When doing it, we should try to obtain minimal efficient concentrations of active ingredients in order to provide maximum possible safety of disinfection procedures for medical personnel and patients as well as to reduce aggressive impacts exerted by disinfectants on treated surfaces and to preserve their operational properties.

Conclusion. When examining and assessing efficiency of equipment and disinfectants applied for aerosol disinfections, one should envisage both proper methodical support for research and competent experts as well as relevant technical support in a laboratory provided with specialized validated test equipment which can be applied for a complex disinfectiological examination.

So, we have developed and tested methodical approaches to assessing efficiency of disinfectants and equipment applied for aerosol disinfection; these approaches allow to work out efficient modes for air treatment and eventually to make disinfectant activities more efficient in practical conditions thus reducing risks of airborne infections with aerosol contagion, including HAI.

Funding. The research was not granted any sponsor support.

Conflict of interests. The authors state there is no any conflict of interests.

\section{References}

1. Badamshina G.G., Ziatdinov V.B., Isaeva G.Sh., Kirillova M.A., Zemskova S.S. Analiz riska razvitiya infektsii, svyazannykh s okazaniem meditsinskoi pomoshchi [Analysis of risk for infections related to providing medical assistance]. Analiz riska zdorov'yu, 2017, no. 2, pp. 113-118 (in Russian).

2. Galai V.S. Analiz biozagryaznenii vozdushnoi sredy v chistykh pomeshcheniyakh i otsenka riskov zarazheniya $\mathrm{v}$ nikh [Analysis of biocontaminations of air environment in clean rooms and estimation of risks of their contamination]. Vestnik Moskovskogo gosudarstvennogo stroitel'nogo universiteta, 2017, vol. 12, no. 8 (107), pp. 912-916 (in Russian).

\footnotetext{
${ }^{3}$ SER 2.1.3.2630-10 "Sanitary-epidemiologic requirements to organizations operating in public healthcare or performing medical activities" [web-source]. - URL: http://docs.cntd.ru/document/902217205 (date of visit November 3, 2018).
} 
3. Ziatdinov V.B., Badamshina G.G., Bakirov A.B., Zaripova A.Z., Isaeva G.Sh., Karimov D.O. Mikrobiologicheskii monitoring vozdushnoi sredy v meditsinskikh organizatsiyakh [Microbiological monitoring of the air environment in medical institutions]. Meditsina truda i ekologiya cheloveka, 2016, vol. 8, no. 4, pp. 86-90 (in Russian).

4. Punchenko O.E., Kosyakova K.G., Vasil'eva N.V. Issledovanie mikrobioty vozdukha v mnogoprofil'nom statsionare Sankt-Peterburga [Investigation of the air microbiota in the multidisciplinary hospital of Saint Petersburg]. Gigiena i sanitariya, 2014, no. 5, vol. 93, pp. 33-36 (in Russian).

5. Curtis L.T. Prevention of hospital-acquired infections: review of non-pharmacological interventions. Journal of Hospital Infection, 2008, vol. 69, no. 3, pp. 204-219.

6. Eames I., Tang J.W., Li Y., Wilson P. Airborne transmission of disease in hospitals. Journal of the Royal Society. Interface, 2009, vol. 6, no. 6, pp. 697-702.

7. Jacob. J.T., Steinberg J.P., Kasali A., Zimring C., Denham M.E. The role of the hospital environment in preventing healthcare-associated infections caused by pathogens transmitted through the air. Health Environments Research \& Design Journal, 2013, vol. 7, no. 1, pp. 74-98.

8. O sostoyanii sanitarno-epidemiologicheskogo blagopoluchiya naseleniya v Rossiiskoi Federatsii v 2017 godu: Gosudarstvennyi doklad. - Moscow, Federal'naya sluzhba po nadzoru v sfere zashchity prav potrebitelya i blagopoluchiya cheloveka, 2018, 108 p. (in Russian).

9. Morris C.E., Leyronas C., Nicot P.C. Movement of bioaerosols in the atmosphere and the consequences for climate and microbial evolution. Aerosol Science: Technology and Applications, 2014, pp. 393-415.

10. Li Y., Qian H., Leung G.M., Tang J.W., Yang X. [et al.]. Role of ventilation in airborne transmission of infectious agents in the built environment - a multidisciplinary systematic review. Indoor Air, 2007, vol. 17, no. 1, pp. 2-18.

11. Wu. Y., Chen A., Luhung I., Gall E.T., Chang V.W.-C. [et al.]. Bioaerosol deposition on an air-conditioning cooling coil. Atmospheric Environment, 2016, vol. 144, pp. 257-265.

12. Le Cann P., Bonvallot N., Glorennec P., Deguen S., Goeury C. [et al.]. Indoor environment and children's health: recent developments in chemical, biological, physical and social aspects. International Journal of Hygiene and Environmental Health, 2011, vol. 215, no. 1, pp. 1-18.

13. Isaeva G.Sh., Ziatdinov V.B., Gabidullina S.N. Gigienicheskii i mikrobiologicheskii monitoring vozdushnoi sredy $\mathrm{v}$ nachal'noi shkole [The hygienic microbiological monitoring of air in grade school]. Zdravookhranenie Rossiiskoi Federatsii, 2016, vol. 60, no. 2, pp. 83-88 (in Russian).

14. Nagolkin A.V., Volodina E.V., Akimkin V.G., Borisoglebskaya A.P., Safatov A.S. Obezzarazhivanie vozdukha $\mathrm{v}$ meditsinskikh organizatsiyakh: tendentsii razvitiya [Air disinfection in medical institutions: development trends]. Meditsinskii alfavit, 2015, vol. 1, no. 6, pp. 44-49 (in Russian).

15. Savenko S.M., Logvinov N.L. Kak effektivno prervat' vozdushno-kapel'nyi put' rasprostraneniya vnutribol'nichnykh infektsii - odnu iz naibolee rastushchikh problem sovremennogo zdravookhraneniya? Meditsinskii alfavit, 2017, vol. 3, no. 30 (327), pp. 21-22 (in Russian).

16. Yuzbashev V.G., Abramova I.M. Tekhnologii obezzarazhivaniya I ochistki vozdukha vazhnoe zveno v profilaktike tuberkuleza (analiticheskii obzor). Meditsinskii alfavit, 2012, vol. 1, no. 3, pp.12-18 (in Russian).

17. Nagolkin A.V., Volodina E.V., Akimkin V.G., Borisoglebskaya A.P., Safatov A.S. Inaktivatsiya mikroorganizamov - glavnyi kriterii effektivnosti obezzarazhivaniya vozdukha $\mathrm{v}$ meditsinskikh organizatsiyakh [Microbial inactivation is a major criterion for the efficiency of air disinfection in health care facilities]. Epidemiologiya i infektsionnye bolezni. Aktual'nye voprosy, 2014, no. 6, pp. 57-62 (in Russian).

18. Shestopalov N.V., Akimkin V.G., Fedorova L.S., Skopin A.Yu., Gol'dshtein Ya.A., Golubtsov A.A., Kireev S.G., Polikarpov N.A., Shashkovskii S.G. Issledovanie bakteritsidnoi effektivnosti obezzarazhivaniya vozdukha i otkrytykh poverkhnostei impul'snym ul'trafioletovym izlucheniem sploshnogo spektra [Research of germicidal efficiency of air and open surfaces disinfection 
by pulsed ultraviolet light of continuous spectrum]. Meditsinskii alfavit, 2017, vol. 2, no. 18, pp. 5-9 (in Russian).

19. Popov D.A., Anuchina N.M. Microbiological efficacy of hospital environment decontamination by hydrogen peroxide aerosol. Biomedical Engineering, 2016, vol. 50, no. 2, pp. 92-95.

Shestopalov N.V., Skopin A.Yu., Fedorova L.S., Gololobova T.V. Developing methodical approaches to managing risks of airborne infections with aerosol contagion. Health Risk Analysis, 2019, no. 1, pp. 84-92. DOI: 10.21668/health.risk/2019.1.09.eng

Received: 08.11.2018

Accepted: 24.02 .2019

Published: 30.03.2019 


\section{MEDICAL AND BIOLOGICAL ASPECTS RELATED \\ TO ASSESSMENT OF IMPACTS EXERTED \\ BY RISK FACTORS}

UDC 579.672, 579.674, 579.678

DOI: $10.21668 /$ health.risk/2019.1.10.eng

\section{STUDYING THE CONTAMINATION OF TEA AND HERBAL INFUSIONS WITH MOLD FUNGI AS POTENTIAL MYKOTOXIN PRODUCERS: THE FIRST STEP TO RISK ASSESSMENT (MESSAGE 1)}

\section{L.P. Minaeva, A.I. Aleshkina, Y.M. Markova, A.S. Polyanina, T.V. Pichugina, I.B. Bykova, V.V. Stetsenko, N.R. Efimochkina, S.A. Sheveleva}

Federal Research Centre for Nutrition, Biotechnology and Food Safety, 2/14 Ust inskiy pr., Moscow, 109240, Russian Federation

We analyzed microbe contamination of 54 tea samples (Camellia sp.), black and green one, including those with various additives, and tea infusions, including herbal ones. Tea that was not packed (semi-finished product) came from the following regions: India, Indonesia, Sri-Lanka, Vietnam, Kenya, China; packed tea was bought in retail outlets in the RF. Overall, $83.3 \%$ samples of unpacked tea conformed to microbiological standards as per mold fungi; $16.7 \%$ samples that didn't conform to them contained mold fungi in quantities equal to $1.3-8.2 \cdot 10^{3} \mathrm{CFU} / \mathrm{g}$. We detected discrepancies in quantities of mold fungi in samples with different fraction structure of tea (in average $C F U / g$ ): large-leaved tea contained $2,3 \cdot 10^{2} \mathrm{CFU} / \mathrm{g} ; \mathrm{mid}$ -

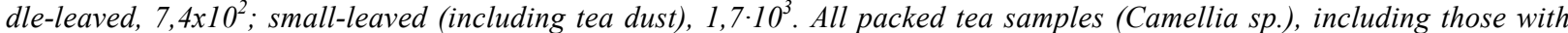
additives, conformed to the requirements fixed by the existing standards. Aspergillus niger mold fungi prevailed in examined tea (Camellia sp.). We revealed substantial microbe contamination in herbal teas; $55 \%$ samples didn't conform to the existing standards and contained more than $10^{4-6} \mathrm{CFU} / \mathrm{g}$ of mold fungi. Besides, $72.2 \%$ of these samples contained more than $10^{5-8} \mathrm{CFU} / \mathrm{g}$ of bacteria; $62.5 \%$ samples of herbal teas that conformed to the standards were contaminated with great quantities of bacteria equal to $8 \cdot 10^{5}-2 \cdot 10^{8}$ CFU/g. We detected Aspergillus, Penicillium, Alternaria, Fusarium in herbal teas microflora; they were producers of hazardous mycotoxins, including emergent ones, and it could potentially cause contamination of herbal teas with mycotoxins. These data will be applied in future to identify hazards caused by mycotoxic fungi in tea and tea infusions as well as to update existing standards.

Key words: tea, Camellia sp., herbal tea, mold fungi, producers of mycotoxins, producers of emergent mycotoxins, mycotoxins, microbe contamination, bacteria.

(C) Minaeva L.P., Aleshkina A.I., Markova Y.M., Polyanina A.S., Pichugina T.V., Bykova I.B., Stetsenko V.V., Efimochkina N.R., Sheveleva S.A., 2019

Liudmila P. Minaeva - Candidate of Technical Sciences, Senior Researcher at the Laboratory for biologicalsafety and nutrimicrobiom analysis (e-mail: liuminaeva-ion@mail.ru; tel. 8 (495) 698-53-83; ORCID: http://orcid.org/0000-0003-1853-5735).

Anastasiya I. Aleshkina - Junior research worker at the Laboratory of biological safety and nutrimicrobiom analysis (e-mail: ninecatlifes@yandex.ru; tel. 8 (495) 698-53-83; ORCID: https://orcid.org/0000-0001-5010-2038).

Yulia M. Markova - Candidate of Biological sciences, Research worker at the Laboratory for biological safety and nutrimicrobiom analysis (e-mail: yulia.markova.ion@gmail.com; tel. 8 (495) 698-53-83; ORCID: http://orcid.org/0000-0002-2631-6412).

Anna S. Polyanina - Research assistant at the Laboratory for biological safety and nutrimicrobiom analysis (e-mail: polyanina.anna.sergeevna@gmail.com; tel. 8 (495) 698-53-83; ORCID: https://orcid.org/0000-0002-2766-7716).

Tatiana V. Pichugina - Candidate of Technical Sciences, Researcher at the Laboratory for biological safety and nutrimicrobiom analysis (e-mail: bbtvp@ion.ru; tel. 8 (495) 698-53-83; ORCID: http://orcid.org/0000-0002-4632-7119).

Irina B. Bykova - Researcher at the Laboratory for biological safety and nutrimicrobiom analysis (e-mail: bikova@ion.ru; tel. 8 (495) 698-53-83; ORCID: https://orcid.org/0000-0001-7288-312X).

Valentina V. Stetsenko - Junior researcher at the Laboratory for biological safety and nutrimicrobiom analysis (e-mail: stetsenko_valentina1992@mail.ru; tel. 8 (495) 698-53-83; ORCID: http://orcid.org/0000-0001-6470-171X).

Natalia R. Efimochkina - Doctor of Biological Sciences, Leading researcher at the Laboratory for biological safety and nutrimicrobiom analysis (e-mail: karlikanova@ion.ru; tel. 8 (495) 698-53-83; ORCID: http://orcid.org/0000-0002-9071-0326).

Svetlana A. Sheveleva - Doctor of Biological Sciences, head of the Laboratory for biological safety and nutrimicrobiom analysis (e-mail: sheveleva@ion.ru; tel. 8 (495) 698-53-83; ORCID: https://orcid.org/0000-0001-5647-9709). 
Microscopic mold fungi are global contaminants polluting food vegetable raw materials; their prevalence is primarily determined by natural factors, and only to a certain extent, by anthropogenic influence. They can penetrate vegetable raw materials at all the stages including vegetation, picking, transportation, and storage. Certain species of mold fungi are potentially able to synthesize mycotoxins (MT) as secondary metabolites, and special attention should be paid to their producers as they contaminate food products. The most significant fungi here belong to the following stems: Aspergillus, Penicillium, Fusarium, Alternaria and Claviceps [1]. A MT range produced by these microscopic fungi includes both highly toxic ones such as zearalenone (ZEA), deoxynivalenol (DON), aflatoxins (AF B1), fumonisins (FB1 and FB2), ochratoxin A (OTA) and patulin, T-2 toxin, with their contents in food products being strictly standardized in the Customs Union countries (CU TR 021/2011) ${ }^{1}$ and abroad [2-8], and emergent mycotoxins (EMT) that have not been studied enough: enniatins, bovericin, moniliformin, fuzproliferin, fusaric acid, sterigmatocystin, emodin, mycophenolic acid, alternariol and its monomethyl ether, tenuazonic acid, asperglaucid, and tentoxin, that can simultaneously occur in food products and make its toxic contribution into an end product [9-12]. Mycotoxins cause actual hazards for people as they exert carcinogenic, mutagenic, and teratogenic impacts, suppress the immune system, and can induce a number of diseases [13].

Bearing safety in mind, it is important to examine contamination with mold fungi, including EMT producers, that occurs in vegetable food products consumed by population in large volumes, for example, tea. As per data obtained in marketing research conducted in 2003 and 2018, 82-83\% respondents drank tea every day $[14,15]$. As there is a great variety of tea types distributed on the consumer market, such concepts as "tea" and "tea drinks" are often mixed up. According to the State Stan- dard (GOST) ${ }^{2}$ "tea" is made of tea leaves from Camellia stem plants, Theaceae family (Camelliasp.) and doesn't contain any other components; "tea with additives" should contain not less than $50 \%$ tea as well as include some other components; "tea drink" is made of vegetable raw materials with probably added tea (mass fraction is not more than 50\%) and other components, and this concept covers herbals teas as well. Tea leaves that were at primary processing stages, including drying, are a semifinished product.

As pace of life is becoming faster, people are switching from leaf teas to packed ones (tea in bags for brewing); thus, as per market analysis data obtained in 2016, packed teas had about $63 \%$ share of the overall consumption [18]. There are also changes in preferences of specific consumer groups as mature and elderly people tend to choose green or fruit tea; as per data collected in 2016 green tea had 23\% share of the market [15], fruit and herbal teas, $3.5-5 \%$, and these market segments were considered to be growing [15-16].

Most people tend to think that tea is a "useful", "healthy" and "safe" drink and it is due to both heat treatment involved in the process of making it and absence of any relations with food intoxications. CU TR fixes microbiological standards for tea and tea products that are to be met in the RF; these parameters are given in Table 1.

Concentration of mycotoxic aflatoxin B1 produced by $A$. flavus, $A$. parasiticus, $A$. ochraceoroseus, A. pseudotamarii, A. bombycis, A. nomius is regulated in tea and tea products and it shouldn't exceed $0.005 \mathrm{mg} / \mathrm{kg}$ [17].

Safety parameters regulated and standardized in other countries are determined by national legislation and can include either a single parameter or a whole set of them. Parameters recommended by Tea \& Herbal Infusions Europe (THIE, 2018) [18-19], American Herbal Products Association (AHPA, 2016) [20] and by the WHO (2007) [21] are given in Table 2 .

\footnotetext{
${ }^{1}$ The Customs Union Technical Regulations CU TR 021/2011 "On food products safety".

${ }^{2}$ GOST 32593-2013 Tea and tea products. Terms and definitions.
} 
Table 1

Microbiological safety parameters for tea and tea products according to the requirements fixed in the CU TR 021/2011

\begin{tabular}{|c|c|c|c|c|c|c|c|c|}
\hline \multirow[t]{2}{*}{ A product } & $\begin{array}{l}\text { Amounts of } \\
\text { mesophilic } \\
\text { aerobic and } \\
\text { facultatively } \\
\text { anaerobic mi- } \\
\text { croorganisms } \\
\text { (AMAFAnM) }\end{array}$ & Mold & Yeast & B.cereus & $\begin{array}{c}\text { Coliform } \\
\text { bacteria }\end{array}$ & E. coli & S.aureus & $\begin{array}{l}\text { Pathogenic } \\
\text { bacteria } \\
\text { including } \\
\text { salmonella }\end{array}$ \\
\hline & \multicolumn{4}{|c|}{$\mathrm{CFU} / \mathrm{g}$, not more } & \multicolumn{4}{|c|}{$\begin{array}{c}\text { Mass of a product, } \mathrm{g}, \\
\text { where microorganisms are not allowed }\end{array}$} \\
\hline Tea & - & $10^{3}$ & - & - & - & - & - & - \\
\hline $\begin{array}{l}\text { Mixtures of dried vege- } \\
\text { table raw materials for } \\
\text { making hot non- } \\
\text { alcoholic drinks }\end{array}$ & $5 \times 10^{5}$ & 100 & 100 & - & 1 & - & - & 25 \\
\hline $\begin{array}{l}\text { BAD to food - mix- } \\
\text { tures of dried medicinal } \\
\text { herbs (teas) }\end{array}$ & $5 \times 10^{5}$ & $10^{3}$ & 100 & - & 0.01 & 0.1 & - & 10 \\
\hline $\begin{array}{l}\text { BAD-teas (dried mix- } \\
\text { tures for children) }\end{array}$ & $5 \times 10^{3}$ & 50 & 50 & 200 & 0.1 & 1 & 1 & 25 \\
\hline $\begin{array}{l}\text { - Herbal instant teas } \\
\text { (made of plants) for } \\
\text { pregnant and breast- } \\
\text { feeding women; } \\
\text { - Herbal drink for chil- } \\
\text { dren (herbal tea) }\end{array}$ & $5 \times 10^{3}$ & 50 & 50 & 100 & 1 & - & - & 25 \\
\hline
\end{tabular}

Table 2

Microbiological parameters for tea, herbal drinks, and raw materials

\begin{tabular}{|c|c|c|c|c|c|c|}
\hline A product & $\begin{array}{c}\text { Aerobic } \\
\text { bacteria } \\
\text { quantity, } \\
\text { CFU/g }\end{array}$ & $\begin{array}{l}\text { Yeast, } \\
\text { CFU/g }\end{array}$ & $\begin{array}{l}\text { Mold, } \\
\text { CFU/g }\end{array}$ & $\begin{array}{c}\text { Enterobac- } \\
\text { teriaceae, } \\
\text { CFU } / \mathrm{g}\end{array}$ & $\begin{array}{l}\text { E. coli, } \\
\mathrm{CFU} / \mathrm{g}\end{array}$ & $\begin{array}{l}\text { Salmonella, } \\
\text { absence in } \\
\text { a mass of } \\
\text { product, } g\end{array}$ \\
\hline \multicolumn{7}{|c|}{ Tea \& Herbal Infusions Europe (THIE) } \\
\hline Tea (C. sinensis) & $\leq 10^{7}$ & $\leq 10^{6}$ & $\leq 10^{5}$ & - & $\leq 10^{2}$ & 125 \\
\hline Raw materials for herbal teas (dried) & $\leq 10^{8}$ & $\leq 10^{6}$ & $\leq 10^{6}$ & - & $\leq 10^{4}$ & 125 \\
\hline Herbal teas (dried) & $\leq 10^{7}$ & $\leq 10^{5}$ & $\leq 10^{5}$ & - & $\leq 10^{3}$ & 125 \\
\hline $\begin{array}{l}\text { Drinks made of tea (C. sinensis) } \\
\text { and herbal teas (cooled) }\end{array}$ & $\leq 10^{4}$ & $\leq 10^{2}$ & $\leq 10^{2}$ & - & $\leq 10^{1}$ & 125 \\
\hline \multicolumn{7}{|c|}{ American Herbal Products Association (AHPA) } \\
\hline Herbal additives (raw materials) & $\leq 10^{7}$ & $\leq 10^{5}$, & otally & $\leq 10^{4}$ & $\leq 10$ & 25 \\
\hline \multicolumn{7}{|c|}{ World Health Organization (BO3) } \\
\hline \multirow{2}{*}{$\begin{array}{l}\text { Herbal medications taken after } \\
\text { being brewed with boiling water }\end{array}$} & $\leq 10^{7}$ & \multicolumn{2}{|c|}{$\leq 10^{4}$, totally } & $\leq 10^{3}$ & 10 & 1 \\
\hline & \multicolumn{6}{|c|}{ Not allowed in $1 \mathrm{~g}$, Clostridia and Shigella } \\
\hline \multirow{2}{*}{$\begin{array}{l}\text { Vegetable materials to be con- } \\
\text { sumed as food }\end{array}$} & $\leq 10^{5}$ & $\leq 10^{3}$, & otally & $\leq 10^{3}$ & 10 & 1 \\
\hline & \multicolumn{6}{|c|}{ Not allowed in $1 \mathrm{~g}$, Clostridia and Shigella } \\
\hline
\end{tabular}


But still, there are no unified criteria in the international legislation. Low humidity of tea prevents microbe contamination development; however, when requirements to picking and processing are violated, or cross contamination occurs at a manufacturing plant, it can cause elevated risks of finished products being contaminated, and it is particularly true for herbal teas.

Research on microbe contamination that can be found in foreign literature primarily focuses on teas that underwent deep fermentation, for example, Pu'er teas; but such teas have rather insignificant share on the market, and as for mass consumption teas, there is very little research on them or such research is fragmentary [22-24]. The report on the results of the 23rd session held by the FAO Intergovernmental Group (IGG) on Tea in Hangzhou, China, on May 17-20, 2018 which was presented to the FAO Committee on Commodity Problems highlighted there was a necessity to promote scientific research in the sphere of natural contaminants and to reveal relationships that caused their occurrence in tea [25].

At present experts are being discussing an issue on microbiological parameters fixed for tea in the RF and possible alterations to them in order to harmonize the RF national legislation with international requirements recommended by the WHO. Given that, it seems vital to examine contamination of variable teas and tea products distributed in the Customs Union countries with mold fungi which are potential MT producers (including EMT); it is also necessary to assess existing microbiological standards as regards their efficiency for providing safety of tea and tea products for population.

Our research goal was to examine contamination of variable teas and tea products with mold fungi - mycotoxins producers, and also to determine bacterial contamination for further risk assessment and updating of hygienic standards existing for these products.

Data and methods. We performed experimental research on 54 samples that in- cluded: unpacked traditional tea (Camelliasp.) (semi-finished product), green and black, totally 30 samples from 6 tea-producing regions (Vietnam, India, Indonesia, Kenya, China, Sri-Lanka); packed tea divided into three groups: traditional tea (Camelliasp.), tea with additives, 3 samples of each, and herbal teas, 18 samples overall (monocomponent ones: Sudan rose, fermented sallybloom, thyme, mint, camomile; and multicomponent ones containing: echinacea, origanum, brandy mint, nettle, thyme, camomile, wild rose, sage, violet, licorice, St. John's wort, melilot, inula, hawthorn, everlasting, tansy, holy-thistle, marigold, sarcarolla, birch leaves, fermented sally-bloom etc.). Unpacked tea samples were provided by wholesale companies, and packed tea samples were bought in retail outlets. Prior to microbiological research all samples were kept unopened under room temperature.

Mycological inoculation was accomplished according to the State Standard GOST 10444.12-2013 ${ }^{3}$, we applied microscopic fungi identifiers for taxonomic identification [27-29], and determined amounts of mesophilic aerobic and facultatively anaerobic microorganisms according to the State Standard GOST 10444.15-94 ${ }^{4}$.

Results. Safety of food products for consumers is provided by compliance with the fixed standards, and as data on new hazards and risk factors are accumulated or existing hazards are reduced somehow, these standards are to be updated. We examined microbe contamination of tea and tea products focusing on mold fungi as well as bacteria amounts of which in products allow to judge whether a production is hygienically clean or not.

Determining contamination of tea samples with mold fungi. The results of our research on contamination of unpacked tea (Camellia sp.) with mold fungi in 30 samples as per regions of origin are given in Table 3.

\footnotetext{
${ }^{3}$ GOST 10444.12-2013 Microbiology of food products and animal forage. Procedures for detecting and canculating amounts of yeast and mold fungi.

${ }^{4}$ GOST 10444.15-94 Food products. Procedures for determining amounts of mesophilic aerobic and facultatively anaerobic microorganisms.
} 
Table 3

Distribution of unpacked tea samples as per levels of contamination with mold fungi obtained via mycological analysis

\begin{tabular}{|l|c|c|c|c|c|c|c|}
\hline \multirow{2}{*}{$\begin{array}{c}\text { Region } \\
\text { of origin }\end{array}$} & $\begin{array}{c}\text { Number } \\
\text { of sam- } \\
\text { ples }\end{array}$ & \multicolumn{2}{c|}{ Mold contents, CFU/g } & \multicolumn{2}{c|}{ As per specific ranges, CFU/g (number of samples) } \\
\cline { 3 - 8 } & Average & $\begin{array}{c}\text { Range of } \\
\text { amounts }\end{array}$ & $\begin{array}{c}\text { Less than } \\
500\end{array}$ & $500-1,000$ & $1,000-5,000$ & $\begin{array}{c}\text { More than } \\
5,000\end{array}$ \\
\hline & 5 & 56 & $18-150$ & 5 & - & - & - \\
\hline Vietnam & 5 & 1,577 & $173-5,850$ & 3 & - & 1 & 1 \\
\hline India & 5 & 2,364 & $110-8,250$ & 2 & 1 & 1 & 1 \\
\hline Indonesia & 5 & 87 & $11-340$ & 5 & - & - & - \\
\hline Kenya & 5 & 609 & $20-2,750$ & 4 & - & 1 & - \\
\hline $\begin{array}{l}\text { Sri-Lanka } \\
\text { (Ceylon) }\end{array}$ & 1 & 600 & 600 & - & 1 & - & - \\
\hline China & \multicolumn{7}{|c|}{ Green tea } \\
\hline
\end{tabular}

As we can see from the Table 3, contents of mold fungi in the examined samples of unpacked tea varied from 11 to $8,250 \mathrm{CFU} / \mathrm{g}$ in black tea and from 28 to $710 \mathrm{CFU} / \mathrm{g}$ in green tea. Standards were violated in 5 out of 26 $(16.7 \%)$ black tea samples. As we examined all the samples as per regions of origin, we revealed that all the samples from Vietnam, Kenya, and China, as well as 4 samples from Sri-Lanka, 3 from Indonesia and 3 from India corresponded to the fixed standards but at the same time some samples from India and Indonesia ( 2 out of 5 for each country) and SriLanka (1 out of 5$)$ contained mold fungi in quantities higher than the standards. Therefore, most samples $(83.3 \%)$ of unpacked tea $(\mathrm{Ca}$ mellia sp.) corresponded to the existing standards and mold fungi contents in them didn't exceed $10^{3} \mathrm{CFU} / \mathrm{g}$.

As we compared mold fungi contents in samples divided as per their fractional structure according to the State Standards GOST ISO $11286-2014^{5}$, GOST $32573-2013^{6}$, and GOST 32574-2013 ${ }^{7}$, average data were distributed as follows: large-leaved teas (12 samples) contained $1.6 \times 10^{2} \mathrm{CFU} / \mathrm{g}$; average-leaved teas

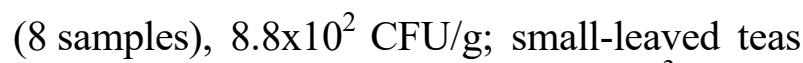
(including tea dust) (10 samples), $1.7 \times 10^{3} \mathrm{CFU} / \mathrm{g}$, and it means that small-leaved tea (including tea dust) that is usually used to make granulated and packed tea is the most contaminated one with mold fungi contents in it exceeding the fixed standards.

Having examined mold fungi species in tea inoculations, we revealed that Aspergillus niger prevailed and it was quite characteristic for traditional tea (Camellia sp.) [24].

Results of mycological inoculations obtained for packed tea samples are given in Table 4.

All the examined samples of packed traditional tea (Camellia sp.), including tea with additives corresponded to the standards as mold fungi contents in them didn't exceed $10^{3} \mathrm{CFU} / \mathrm{g}$.

But only 8 out of $18(44.4 \%)$ herbal teas met the fixed requirements as mold fungi contents in the remaining ten samples exceeded $5 \times 10^{3}$ and even reached $10^{6} \mathrm{CFU} / \mathrm{g}$. Species identification revealed fungi from more than 5 stems in all the herbal tea samples including Aspergillus sp, Penicillium sp., Alternaria sp., Fusarium sp., Cladosporium sp. etc.; certain species from these stems produce toxins. We

\footnotetext{
${ }^{5}$ GOST ISO 11286-2014 Tea. Classification as per tea leaves sizes performed with grain-size analysis.

${ }^{6}$ GOST 32573-2013 Black tea. Specification.

${ }^{7}$ ГОСТ 32574-2013 Green tea. Specification.
} 
Table 4

Distribution of packed tea samples as per levels of contamination with mold fungi obtained via mycological analysis

\begin{tabular}{|l|c|c|c|c|c|c|c|}
\hline \multirow{2}{*}{ Packed tea } & \multirow{2}{*}{$\begin{array}{c}\text { Number } \\
\text { of sam- } \\
\text { ples }\end{array}$} & \multicolumn{2}{|c|}{ Mold contents, CFU/g } & \multicolumn{3}{c|}{$\begin{array}{c}\text { As per specific ranges, CFU/g } \\
\text { (number of samples) }\end{array}$} \\
\cline { 3 - 8 } & Average & Range of amounts & $<500$ & $500-1000$ & $1000-5000$ & $>5000$ \\
\hline $\begin{array}{l}\text { Traditional } \\
\text { (black and green) }\end{array}$ & 3 & $8.6 \times 10^{2}$ & $180-2200$ & 2 & 1 & - & - \\
\hline $\begin{array}{l}\text { With additives } \\
\text { (black) }\end{array}$ & 3 & $3 \times 10^{2}$ & $<5-900$ & 2 & 1 & - & - \\
\hline Herbal & 18 & $9.7 \times 10^{4}$ & $<5-10^{6}$ & 7 & 1 & - & 10 \\
\hline
\end{tabular}

should note that such a variable microflora is specific for wild meadow herbs [29]. We performed preliminary analysis of toxins formation in vitro by mold contaminants extracted from several examined samples of herbal teas; the results indicated these contaminants were able to synthesize fumonisin B1. Occurrence of fumonisin $\mathrm{B} 1$ in herbal teas and medicinal plants was detected in Turkey [30]. Extended results on toxin formation by extracted fungi strains will be obtained in subsequent research.

Determining bacterial contamination of tea. Spore-forming bacteria are natural antagonists of mold fungi and their ratio can determine microbe contamination of vegetable raw materials. Mycological analysis of herbal teas allowed to reveal that bacteria were growing actively in spite of antibiotics contents in a nutrient medium during mycological analysis. To assess hygienic state of variable tea and tea products, we analyzed their contamination with bacteria; results obtained for unpacked tea and given in Table 5; for packed tea, in Table 6 .

Most samples of traditional packed tea, 29 out of 30 (96.7\%), including both black and green tea, contained overall amounts of bacteria that varied from $<1.5 \times 10^{2}$ to $5 \times 10^{3} \mathrm{CFU} / \mathrm{g}$, and only 1 sample (3.3\%) which came from Sri-Lanka contained bacteria in amount hat reached $6.7 \times 10^{3} \mathrm{CFU} / \mathrm{g}$.

As we can see from Table 6, amounts of bacteria were low in all the examined samples of packed traditional tea (Camellia sp.), namely in 5 out of $6(83.3 \%)$, and in 2 samples of tea with additives and didn't exceed $5 \times 10^{2}$ $\mathrm{CFU} / \mathrm{g}$; it amounted to $5 \times 10^{4} \mathrm{CFU} / \mathrm{g}$ only in 1 sample of tea with additives.

As for herbal teas, only 5 samples out of $18(27.8 \%)$ contained bacteria in amounts within $5 \times 10^{2}-5 \times 10^{5} \mathrm{CFU} / \mathrm{g}$ range, but most of them, 13 out of $18(72.2 \%)$, contained bacteria in amounts higher than $5 \times 10^{5} \mathrm{CFU} / \mathrm{g}$ and sometimes this parameter even reached $2 \times 10^{8}$ CFU/g (leaves of fermented sally-bloom). It should be noted, that 10 samples $(55.5 \%)$ in this group didn't correspond to microbiological standards as per mold fungi either and were considered "dirty" and 4 out of 8 "clean" samples contained bacteria in amounts varying from $7 \times 10^{5}$ to $2 \times 10^{8} \mathrm{CFU} / \mathrm{g}$. We should also note that increased bacterial contamination which was on average equal to $4 \times 10^{7} \mathrm{CFU} / \mathrm{g}$ was detected in 5 samples of herbal teas that contained leaves of fermented sally-bloom. It was apparently due to fermentation conditions favorable for development of spore-forming bacteria which, due to their antagonistic activity, are able to suppress mold fungi.

The obtained results indicate that microbiological standards for tea fixed in the CU TR 021/2011 don't provide bacterial cleanness of herbal teas, and overall amount of detected bacteria is higher than standards fixed for products that contain vegetable raw materials (Table 1) as well as standards for overall amounts of bacteria recommended by the WHO, THIE, and AHPA (Table 2).

Bacterial contamination in all the examined tea samples with high contents of bacteria was caused by spore-forming bacilli Bacillus sp. 
Table 5

Distribution of unpacked tea samples as per contamination with bacteria obtained via microbiological analysis

\begin{tabular}{|l|c|c|c|c|c|c|c|}
\hline \multirow{2}{*}{ Region } & \multirow{2}{*}{$\begin{array}{c}\text { Number } \\
\text { of samples }\end{array}$} & \multicolumn{2}{c|}{ AMAFAnM, CFU/g } & \multicolumn{5}{c|}{$\begin{array}{c}\text { As per specific ranges, CFU/g } \\
\text { (number of samples) }\end{array}$} \\
\cline { 3 - 8 } & & Average & Range of amounts & $<5 \times 10^{2}$ & $\begin{array}{c}>5 \times 10^{2}- \\
5 \times 10^{3}\end{array}$ & $\begin{array}{c}>5 \times 10^{3}- \\
5 \times 10^{5}\end{array}$ & $>5 \times 10^{5}$ \\
\hline \multicolumn{7}{|c|}{ Black tea } \\
\hline Vietnam & 5 & 470 & $<1.5 \times 10^{2}-1.3 \times 10^{3}$ & 4 & 1 & - & - \\
\hline India & 5 & 232 & $<1.5 \times 10^{2}-8 \times 10^{2}$ & 4 & 1 & - & - \\
\hline Indonesia & 5 & 13 & $<1.5 \times 10^{2}$ & 5 & - & - & - \\
\hline Kenya & 5 & 1530 & $2 \times 10^{2}-3.3 \times 10^{3}$ & 2 & 3 & - & - \\
\hline Sri-Lanka & 5 & 1365 & $<1.5 \times 10^{2}-6.7 \times 10^{3}$ & 4 & - & 1 & - \\
\hline China & 1 & 600 & 600 & - & 1 & - & - \\
\hline \multicolumn{7}{|c|}{} & \multicolumn{7}{|c|}{ Green tea } & & & - \\
\hline China & 4 & 98 & $<1.5 \times 10^{2}-2.5 \times 10^{2}$ & 4 & - & - & - \\
\hline Totally, abs. & 30 & - & - & 24 & 5 & 1 & 0 \\
\hline Totally, \% & 100 & - & - & 76.7 & 20 & 3.3 & 0 \\
\hline
\end{tabular}

Table 6

Distribution of unpacked tea samples as per contamination with bacteria obtained via microbiological analysis

\begin{tabular}{|l|c|c|c|c|c|c|c|}
\hline \multirow{2}{*}{ Packed tea } & \multirow{2}{*}{$\begin{array}{c}\text { Number } \\
\text { of samples }\end{array}$} & \multicolumn{3}{|c|}{ AMAFAnM, CFU/g } & \multicolumn{3}{c|}{$\begin{array}{c}\text { As per specific ranges, CFU/g } \\
\text { (number of samples) }\end{array}$} \\
\cline { 3 - 8 } & & Average & Range of amounts & $<5 \times 10^{2}$ & $\begin{array}{c}>5 \times 10^{2}- \\
5 \times 10^{3}\end{array}$ & $\begin{array}{c}>5 \times 10^{3}- \\
5 \times 10^{5}\end{array}$ & $>5 \times 10^{5}$ \\
\hline Traditional & 3 & 77 & $<1.5 \times 10^{2}-1.8 \times 10^{2}$ & 3 & - & - & - \\
\hline With additives & 3 & $1.6 \times 10^{4}$ & $<1.5 \times 10^{2}-5 \times 10^{4}$ & 2 & - & 1 & - \\
\hline Herbal & 18 & $1.3 \times 10^{7}$ & $4.7 \times 10^{3}-2 \times 10^{8}$ & - & 1 & 4 & 13 \\
\hline
\end{tabular}

Determining microbe contamination of tea after heat treatment. To assess whether tea is safe when it is ready for consumption, it is necessary to examine how heat treatment during brewing influences microbe contamination of tea with mold fungi and bacteria. In order to do that, we took 6 samples with different microbe contamination (3 out of each group: traditional unpacked tea and herbal tea), poured them with boiling water (in a ratio $10 \mathrm{~g}$ tea per $90 \mathrm{ml}$ of water), then brewed them for $10 \mathrm{~min}$ utes (just as any ordinary tea); infusions were then cooled and inoculated, and results recalculated as per dry tea are given in Table 7 .

As we can see from the Table 7, heat treatment results in considerable fall in amounts of mold fungi in all tea samples from its initial level that was $>10^{2}-10^{6} \mathrm{CFU} / \mathrm{g}$ to a level below test sensitivity which was $<5 \mathrm{CFU} / \mathrm{g}$. However, we
Table 7

Comparative analysis of mold fungi and bacteria contents in inoculations before and after heat treatment: results obtained for traditional teas and herbal teas

\begin{tabular}{|c|c|c|c|c|}
\hline \multirow{2}{*}{ Sample } & Mold fungi, CFU/g & \multicolumn{2}{c|}{ AMAFAnM, CFU/g } \\
\cline { 2 - 5 } & $\begin{array}{c}\text { Initial } \\
\text { product }\end{array}$ & $\begin{array}{c}\text { After } \\
\text { brewing }\end{array}$ & $\begin{array}{c}\text { Initial } \\
\text { product }\end{array}$ & $\begin{array}{c}\text { After } \\
\text { brewing }\end{array}$ \\
\hline \multicolumn{5}{|c|}{ Traditional (unpacked) tea } \\
\hline 1 & $5.8 \times 10^{3}$ & $<5$ & $8 \times 10^{2}$ & $<1.5 \times 10^{2}$ \\
\hline 2 & $8.2 \times 10^{3}$ & 20 & $<1.5 \times 10^{2}$ & $<1.5 \times 10^{2}$ \\
\hline 3 & $6 \times 10^{2}$ & $<5$ & $1.3 \times 10^{3}$ & $<1.5 \times 10^{2}$ \\
\hline \multicolumn{5}{|c|}{ Herbal (packed) tea } \\
\hline 4 & $\begin{array}{c}\text { Less } \\
\text { than 5 }\end{array}$ & $<5$ & $2 \times 10^{8}$ & $6.1 \times 10^{4}$ \\
\hline 5 & $10^{6}$ & $<5$ & $5 \times 10^{6}$ & $2.7 \times 10^{5}$ \\
\hline 6 & $2.2 \times 10^{4}$ & $<5$ & $9 \times 10^{6}$ & $4 \times 10^{6}$ \\
\hline
\end{tabular}


didn't observe a similar fall as regards bacteria: their amount dropped to less than $1.5 \times 10^{2}$ $\mathrm{CFU} / \mathrm{g}$ in all 3 samples of traditional tea regardless of their levels in initial products while as for herbal teas, the greatest reduction, more than by 3,000 times, was detected in sample No. 4; bacteria amount dropped by 18 times in sample No. 5; and it fell by only 2.25 times in sample No. 6. And we should also note that amounts of bacteria remained rather high in all three samples of herbal tea even after heat treatment, from $6.1 \times 10^{4}$ to $4 \times 10^{6} \mathrm{CFU} / \mathrm{g}$ (recalculated as per dry product). These differences in inhibition under heat treatment are apparently caused by prevalence of spore-forming bacteria which are heat-resistant over vegetative ones.

Conclusion. We analyzed microbiological state of different teas (Camelliasp.): black and green tea (packed and unpacked), including tea with additives, and revealed that most samples corresponded to microbiological standards fixed in CU TR 021/2011 as amounts of mold fungi didn't exceed it in $83.3 \%$ of unpacked tea samples (semi-finished product). All the samples of packed tea, including those with additives, contained less than $10^{3} \mathrm{CFU} / \mathrm{g}$. We detected some differences in mold fungi quantities in tea samples with different fractional structure (in average $\mathrm{CFU} / \mathrm{g}$ ): they were less than $10^{3}$ in large-leaved and average-leaved teas, and $1,7 \times 10^{3}$ in small-leaved teas (including tea dust). Aspergillusniger prevailed among mold fungi detected in tea (Camelliasp.). After traditional tea (Camelliasp.) was brewed, the amount of mold fungi and bacteria in brewed drinks dropped from the initial level equal to $10^{2-3} \mathrm{CFU} / \mathrm{g}$ to a level below test sensitivity and it made tea a safer drink for consumption. As we compared standards existing for tea in the Customs Union countries with standards recommended for tea (C.sinensis) by THIE association, we revealed that $\mathrm{CU}$ TR 021/2011 fixed stricter requirements to mold fungi contents, but a set of microbiological parameters fixed by THIE standards included 4 additional groups of microorganisms.
High microbe contamination was most frequently detected in herbal tea samples, both in terms of mold fungi and bacteria. $55.5 \%$ samples contained mold fungi in quantities higher than $10^{4-6} \mathrm{CFU} / \mathrm{g}$ and it exceeded microbiological standards, and $72.2 \%$ samples contained overall quantity of bacteria that was higher than $10^{5-8} \mathrm{CFU} / \mathrm{g}$. And even when herbal tea samples corresponded to the fixed standards as per mold fungi contents, $62.5 \%$ of them still contained bacteria in quantity that was higher than $5 \times 10^{5}$ CFU/g. After herbal teas were brewed, mold fungi contents went down from the initial $10^{4-6} \mathrm{CFU} / \mathrm{g}$ to a level below test sensitivity, and bacteria quantity dropped from $10^{6-8}$ $\mathrm{CFU} / \mathrm{g}$ to more than $10^{4-6} \mathrm{CFU} / \mathrm{g}$, but it still remained rather high; that is, brewing doesn't provide microbiological safety of herbal tea as opposed to traditional tea (Camelliasp.).

The obtained results that allow to see hygienic state of herbal teas apparently indicate that when the existing microbiological standards for tea are applied to herbal teas, it doesn't provide their cleanness from bacteria. High bacteria quantities up to $2 \times 10^{8} \mathrm{CFU} / \mathrm{g}$ exceed both AMAFAnM parameter fixed in the CU TR 021-2011 for all types of products that include herbal raw materials (Table 1) and quantities of bacteria recommended by the WHO and THIE and AHPA associations (Table 2). In order to make tea products safer for consumers, it is advisable to adjust "tea" category and make it "tea (Camelliasp.)", to single out "herbal tea" as a specific food product that is different from "tea (Camelliasp.)", and to specify a group of products "herbal tea" can be assigned into taking into account a wider list of parameters to be standardized.

We detected a great variety of microscopic fungi in herbal teas including Aspergillussp, Penicilliumsp., Alternariasp., Fusariumsp., Cladosporiumsp.; some of them are toxins producers. It allows us to assume there are mycotoxins produced by these fungi in herbal teas. To obtain a most comprehensive characteristics of tea samples, it is necessary to analyze mycotoxins occurrence in them with a multi-detection procedure aimed at detecting 
a wider range of mycotoxins including emergent ones. When assessing safety of tea and tea products, it is advisable to take into account all the existing data obtained in microbiological and mycotoxicological research.

Funding. This research has been accomplished due to funds provided within a grant by the Russian science foundation (Project No. 18-16-00077) "Emergent mycotoxins in vegetable food products: working out analysis procedures, examining contamination, drawing up a stem characteristics of micromycetes - producers, working out hygienic standards"

Conflict of interests. The authors state there is no any conflict of interests.

\section{References}

1. Bennet, J.W.; Klich, M. Mycotoxins. Clinical Microbiology Reviews, 2003, no. 16, pp. 497-516 [CrossRef].

2. COMMISSION REGULATION (EC) No 1881/2006 of 19.12.2006 setting maximum levels for certain contaminants in foodstuffs. $O J$, L 364, 20.12.2006, 5 p.

3. COMMISSION REGULATION (EU) No 165/2010 of 26.02.2010 amending Regulation (EC) No $1881 / 2006$ setting maximum levels for certain contaminants in foodstuffs as regards aflatoxins. $O J$, 27.2.2010, L 50, 8 p.

4. Commission Regulation (EU) No 1058/2012 of 12.11 .2012 amending Regulation (EC) No 1881/2006 as regards maximum levels for aflatoxins in dried figs Text with EEA relevance. OJ, 13.11.2012, L 313, pp. 14-15.

5. COMMISSION REGULATION (EU) No 105/2010 of 05.02.2010 amending Regulation (EC) No $1881 / 2006$ setting maximum levels for certain contaminants in foodstuffs as regards ochratoxin A. OJ, 2010, L 35, 7 p.

6. Commission Regulation (EU) 2015/1137 of 13.07.2015 amending Regulation (EC) No $1881 / 2006$ as regards the maximum level of Ochratoxin A in Capsicum spp. spices (Text with EEA relevance). $O J, 14.07 .2015$, L 185, pp. 11-12.

7. Commission Recommendation $2013 / 165 / \mathrm{EU}$ of 27.03 .2013 on the presence of T-2 and HT2 toxin in cereals and cereal products Text with EEA relevance. OJ, 03.04.2013, L 91, pp. 12-15.

8. Commission Regulation (EC) No 1126/2007 of 28.09.2007 amending Regulation (EC) No $1881 / 2006$ setting maximum levels for certain contaminants in foodstuffs as regards Fusarium toxins in maize and maize products (Text with EEA relevance) OJ, 29.09.2007, L 255, pp. 14-17.

9. Sedova I., Kiseleva M., Tutelyan V. Mycotoxins in Tea: Occurrence, Methods of Determination and Risk Evaluation. Toxins, 2018, no. 10, 444 p. DOI: 10.3390/toxins10110444 [CrossRef] [PubMed] (in Russian).

10. Zhang L., Dou X.W., Zhang C., Logrieco A.F., Yang M.H. A Review of Current Methods for Analysis of Mycotoxins in Herbal Medicines. Toxins, 2018, no. 10, 65 p. [CrossRef] [PubMed].

11. Jestoi M. Emerging fusarium-mycotoxinsfusaproliferin, beauvericin, enniatins, and moniliformin: a review. Critical Reviews in Food Science and Nutrition, 2008, vol. 48, no. 1, pp. 21-49. DOI: 10.1080/10408390601062021

12. Kovalsky P., Kos G, Nahrer K. [et al.]. Co-Occurrence of Regulated, Masked and Emerging Mycotoxins and Secondary Metabolites in Finished Feed and Maize - An Extensive Survey. Toxins, 2016, vol. 12, no. 8, 363 p. DOI: 10.3390/toxins8120363

13. Wu F., Groopman J.D., Pestka J.J. Public health impacts of foodborne mycotoxins. Annual Review of Food Science and Technology, 2014, no. 5, pp. 351-372 [CrossRef] [PubMed].

14. Martinchik A.N., Baturin A.K. Martinchik A.E. Potreblenie chaya i kofe naseleniem Rossii [Tea and coffee consumption by the population of Russia]. Voprosy pitaniya, 2005, no 3, pp. $42-46$ (in Russian).

15. Marketing research of tea consumers. Marketing research agency FDFgroup. Available at: http://fdfgroup.ru/poleznaya-informatsiya/gotovye-issledovaniya/marketingovoe-issledovanie-potrebiteley-chaya/ (14.11.2018).

16. Tea market of Russia: new opportunities in conditions New Normal. Available at: https://www. retail-loyalty.org/journal retail loyalty/read online/art197823/(14.11.2018) (in Russian).

17. The Aspergillus Website. Available at: https://www.aspergillus.org.uk/metabolites?title=aflatoxin\&field_trivial_name_value $=\&$ field_molecular_weight_value $=\&$ field_produced_by_value $(14.11 .2018)$. 
18. Tea \& Herbal Infusions Europe (THIE). Compendium of Guidelines for Tea (Camellia sinensis). Available at: http://www.thie-online.eu/fileadmin/inhalte/Publications/Tea/2018-08-20_Compendium_of_Guidelines_for_Tea_ISSUE_5.pdf (14.11.2018).

19. Tea \& Herbal Infusions Europe (THIE). Compendium of Guidelines for Herbal and Fruit Infusions. Available at: http://www.thie-online.eu/fileadmin/inhalte/Publications/HFI/2018/2018-07-17_ Compendium_of_Guidelines_for_Herbal_Infusions_-_ISSUE_6.pdf (14.11.2018).

20. American Herbal Product Association (A $\bar{H} \bar{P} A)$. Recommended microbial limits for botanical ingredients (in colony-forming units (CFU)/g). 2016. Available at: http://www.ahpa.org/Portals/0/PDFs/ Policies/14_0206_AHPA_micro_limits_comparisons.pdf (14.11.2018).

21. WHO guidelines for assessing quality of herbal medicines with reference to contaminants and residues. 1. Medicine, Herbal - standards. 2. Quality control. 3. Drug contamination. 4. Chemistry, Analytical. 5. Guidelines. I. World Health Organization, 118 p. Available at: http://apps.who.int/medicinedocs/documents/s14878e/s14878e.pdf (14.11.2018).

22. Zhang Y., Skaar I., Sulyok M., Liu X., Rao M., Taylor J.W. The Microbiome and Metabolites in Fermented Pu-erh Tea as Revealed by High-Throughput Sequencing and Quantitative Multiplex Metabolite Analysis. PLoS ONE, 2016, no. 11, e0157847 [CrossRef] [PubMed].

23. Haas D., Pfeifer B., Reiterich C., Partenheimer R., Reck B., Buzina W. Identification and quantification of fungi and mycotoxins from Pu-erh tea. International Journal of Food Microbiology, 2013, no. 166, pp. 316-322 [CrossRef] [PubMed].

24. Carraturo F., De Castro O., Troisi J., De Luca A., Masucci A., Cennamo P., Trifuoggi M., Aliberti F. Comparative assessment of the quality of commercial black and green tea using microbiology analyses. BMC Microbiology, 2018, no. 18, 4 p. [CrossRef] [PubMed].

25. CCP 18/INF/13 (CCP: TE 18/Report) Report of the Twenty-Third Session of the Intergovernmental Group on Tea (Hangzhou, the People's Republic of China, 17-20 May 2018). Available at: http://www.fao.org/ fileadmin/user_upload/bodies/CCP_72/CCP72_INF/MX217_INF_13/MX217_CCP_18_INF_13_en.pdf (14.11.2018) (in Russian).

26. Bilay V.I., Kurbatskaya Z.A. The manual for Identification toxin-producing micromycetes. Kiyev, Naukova dumka Publ., 1990, 236 p. (in Russian).

27. Sutton D.A., Fothergill A.W., Rinaldi M.G; Trans. from Engl. K.L. Tarasova K.L., Kovaleva Yu.N. Edited by Dorozhkovoy I.R. Guide to Clinically Significant Fungi. Moscow, Mir Publ., 200, vol. XVI, 468 p. (in Russian).

28. Isayeva V.S., Rattel N.N., Volkova T.N. Kratkii atlas postoronnikh mikroorganizmov v pivovarennom proizvodstve [Summary Atlas of Foreign Microorganisms in the Brewing Industry]. Moscow, 1997, 95 p. (in Russian).

29. Burkin A.A., Kononenko G.P. Mycotoxin contamination of meadow grasses in European Russia. Agricultural Biology, 2015, vol. 50, no. 4, pp. 503-512. DOI: 10.15389/agrobiology.2015.4.503eng (in Russian).

30. Omurtag GZ, Yazicioğlu D. Determination of fumonisins B1 and B2 in herbal tea and medicinal plants in Turkey by high-performance liquid chromatography. Journal of Food Protection, 2004, vol. 67, no. 8, pp. 1782-1786.

Minaeva L.P., Aleshkina A.I., Markova Y.M., Polyanina A.S., Pichugina T.V., Bykova I.B., Stetsenko V.V., Efimochkina N.R., Sheveleva S.A. Studying the contamination of tea and herbal infusions with mold fungi as potential mykotoxin producers: the first step to risk assessment (message 1). Health Risk Analysis, 2019, no. 1, pp. 93-102. DOI: 10.21668/health.risk/2019.1.10.eng

Received: 06.12.2018

Accepted: 19.01.2019

Published: 30.03.2019 


\title{
TOXICOLOGICAL RESEARCH IN HEALTH RISK ASSESSMENT
}

UDC 547.853: 615.225: 616.13

DOI: $10.21668 /$ health.risk/2019.1.11.eng

Read

\section{PRO/ANTIOXIDANT ACTIVITY OF A NEW PIR-10 SUBSTANCE (PYRIMIDINE DERIVATIVE) UNDER EXPERIMENTALLY SIMULATED FOCAL CEREBRAL ISCEMIA IN RATS}

\author{
A.V. Voronkov, N.B. Shabanova \\ Pyatigorsk Medical and Pharmaceutical Institute, a branch of Volgograd State Medical University, \\ The RF Public Healthcare Ministry, 11 Kalinina av., Pyatigorsk, 357532, Russian Federation
}

The authors have performed a piece of research that focused on assessing anti-oxidant activity of PIR-10, a new pyrimidine derivative, as a risk factor causing disorders in the cerebral hemodynamics under experimentally simulated focal cerebral ischemia in rats. The experiment was accomplished on male Wistar rats with body weight equal to 220-240. 40 animals were distributed into 4 equal groups $(n=10)$. The first group was made up of falsely operated animals; the second one was a negative control group; animals from both these groups were given a water suspension purified with TWEEN-80 in equivalent volumes. The third group included rats that were given a reference medication, namely Mexidol (emoxypine) $(50 \mathrm{mg} / \mathrm{kg})$. Animals from the fourth group were given an experimental substance with a laboratory cipher PIR-10 $(50 \mathrm{mg} / \mathrm{kg})$. All the examined objects were introduced intraperitoneally immediately after a surgery and during 3 days. Local cerebral ischemia was induced via coagulation of the left mesencephalic artery. All the manipulations with animals were performed under chloral hydrate narcosis $(350 \mathrm{mg} / \mathrm{kg})$. The performed research allowed to reveal that the given pathology caused an increase in lipid peroxidation products (diene conjugates (DC) and malonic dialdehyde (MDA)) with a simultaneous decrease in endogenous anti-oxidant protection (AOP) enzymes (superoxide dismutase, glutathione peroxidase, catalase). Mexidol application in a dose equal to $50 \mathrm{mg} / \mathrm{kg}$ allowed to correct these disorders due to an increase in antioxidant protection activity and a fall in concentrations of lipid peroxidation products. Introduction of the experimental substance PIR-10 also caused a decrease in DC and MDA concentrations but it didn't produce any effects on AOP system. Therefore, basing on the research results, we can assume that PIR-10 substance is a promising object for further research aimed at creating a medication with antioxidant properties that could allow to minimize epidemiologic risks related to cerebrovascular pathology.

Key words: rats, cerebral ischemia, focal cerebral ischemia, antioxidant activity, lipid peroxidation, free radical oxidation, Mexidol, pyrimidine derivatives.

Introduction. Ischemic cerebral affections occur due to various reasons, and a special role in the process belongs to lipid peroxidation activation and a sharp increase in intensity of free radical oxidation together with antioxidant protection enhancement and its subsequent decompensation [1-4]. A disorder in pro/antioxidant balance causes elevated risks of cerebral ischemia and aggravates its clinical course; dextrose metabolism deterio- rates due to hyperproduction of free radicals and lactate-acidosis grows that results in damages to cellular membranes and, consequently, to cell death [5]. Superoxide dismutase (SOD), catalase, and glutathione peroxidase (GP) are basic enzymes participating in the endogenous antioxidant protection (AOP) as they help to level growing free radical oxidation processes thus reducing damages to the cerebral tissue [6]. Overall, these enzymes provide the so

(C) Voronkov A.V., Shabanova N.B., 2019

Andrej V. Voronkov - Doctor of Medical Sciences, Associate Professor, Head of Pharmacological Department with Clinical Pharmacology course (e-mail: prohor.77@mail.ru; tel.: +7 (879) 332-92-66).

Natal ya B. Shabanova - post-graduate student at Pharmacological Department with Clinical Pharmacology course (e-mail: Vahlushina@mail.ru; tel.: +7 (962) 435-81-87). 
called "first line of defense" against reactionactive free oxygen forms [7]. Previously conducted experiments allowed to determine potential cerebral-protective effects produced by a new pyrimidine derivative with a laboratory cipher PIR-10 when global cerebral ischemia was simulated [8]. Experts have also examined influences exerted by some substances belonging to pyrimidine group on the AOP system [9, 10]. Hence we can assume that this derivative of pyrimidine-4(1H)-on has some antioxidation properties as a possible action mechanism that can help to considerably improve the epidemiologic situation as regards pathologies related to cerebral circulation disorders as well as substantially facilitate management of ischemic stroke risks.

Our research goal was to examine pro/ antioxidant activity of a new substance PIR-10 (pyrimidine derivative) under experimentally simulated focal ischemia in rats.

\section{Data and methods.}

Animals. Laboratory rats were obtained from the vivarium of Pyatigorsk Medical and Pharmaceutical Institute, a branch of Volgograd State Medical University, The RF Public Healthcare Ministry. All the manipulations with animals were accomplished in full conformity with international standards of experimental ethics (The European Convention for the Protection of Vertebrate Animals used for Experimental and other Scientific Purposes (Strasbourg, June 22, 1998)) and requirements fixed in Good laboratory practice (GLP). Animals were kept in makrolon cages with steel lattice covers and a hollow for feeding. Sawdust was used as litter. Rats were kept under controlled conditions similar to those in the vivarium, air humidity being equal to $65 \pm 5 \%$ and air temperature being $22 \pm 2^{\circ} \mathrm{C}$. The light was only natural, nutrition was standard, and all animals had free access to food and water. Water dishes, litter, and cages were replaced with new ones not less than once a week.

Experimental design. The experiment was performed on 40 male Wistar rats with body weight being equal to 220-240 gram. Animals were distributed into 4 equal groups $(n=10)$. The first group included falsely oper- ated (FO) animals, the second group was negative control (NC). Animals from both groups were given a suspension of TWEEN-80 in purified water intraperitoneally. Animals from the third group were given a reference medication, Mexidol, in a dose equal to $50 \mathrm{mg} / \mathrm{kg}$ [11]. Animals from the fourth group were given an experimental substance, PIR-10, in a dose equal to $50 \mathrm{mg} / \mathrm{kg}$ [12]. The examined substance, the reference medication, and purified water with TWEEN-80 were introduced intraperitoneally just after ischemia had been simulated and further on during 3 days. Focal cerebral ischemia was simulated by left-side occlusion of the mesencephalic artery (via its coagulation). A cut was made on dehaired skin of an animal, below and $2 \mathrm{~cm}^{2}$ to the right from the eye, muscles were separated from each other, and the process of the cheekbone was removed. A hole was made in the brainpan with a specially designed drill, and then the left mesencephalic artery was coagulated at the point where it crossed the olfactory tract with a coagulator which we had constructed ourselves [13]. All the manipulations were accomplished when animals were under chloral hydrate narcosis $(350 \mathrm{mg} / \mathrm{kg})$. When 3 days after the operation passed, animals were decapitated and their brains were quickly removed in order to obtain homogenate for further exploration. Cerebral homogenate was prepared on $100 \mathrm{mM}$ Tris-HCl buffer (with pH 7.4 in a ratio 1:10) [14].

Detectable parameters. We estimated diene conjugates (DC) concentrations in cerebral homogenate [basing on the conventional procedure by Z. Placer (1968) modified by V.BG. Gavrilov, M.I. Mishkorudnaya (1983).] [15], as well as TBA-active products concentrations recalculated as per malonic dialdehyde (MDA) [I.D. Stal'naya 1977] [16]. We determined activity of endogenous antioxidant protection enzymes in the post-nuclear fraction of cerebral homogenate including superoxide dismutase [V.N. Chumakov, 1977] [17], catalase [M.A. Korolyuk, 1988] [18], glutathione peroxidase [D.E . Paglia, 1967 modified by J.R. Prohaska, 1977] [19].

Statistical processing. All the obtained data were statistically processed with STATIS- 
TICA 6.0 applied software package (StatSoft, Inc., the USA, compatible with Windows) and Microsoft Excel 2010. We determined a simple mean and its standard error $(M \pm m)$ and applied Shapiro-Wilk test to assess whether distribution was normal. If data were distributed according to normal distribution law, we applied parametric Student's t-test. But if distribution wasn't normal, statistical processing was performed with Mann-Whitney U-test. If significance was higher than 95\% $(\mathrm{P}<0.05)$, discrepancies were considered to be authentic.

Results and discussion. Concentrations of malonic dialdehyde and diene conjugates detected against cerebral ischemia were by $106.8 \%(\mathrm{P}<0.05)$ and $280.6 \%(\mathrm{P}<0.05)$ higher respectively in rats from the negative control group in comparison with falsely operated rats (Table 1). Simultaneously, concentrations of AOP enzymes in the negative control group went down in comparison with falsely operated rats; thus, SOD decreased by $25.2 \%(\mathrm{P}<0.05)$; GP, by $49.9 \%(\mathrm{P}<0.05)$; catalase, on the contrary, went up by $151.6 \%(\mathrm{P}<0.05)$. This increase in catalase concentration can be caused by antioxidation protection system becoming more active as brain damage occurred. We should note that oxidants concentrations were extremely high as we can see from DC and MDA values, and SOD and GP were less active than usual [20]; it can be probably caused by an overall inability of AOP system to overcome hyperproduction of free radicals [21].

Table 1

Influence exerted by Mexidol and PIR-10 on malonic dialdehyde and diene conjugates concentrations in rats' brain homogenate against focal ischemia

\begin{tabular}{|l|c|c|}
\hline \multicolumn{1}{|c|}{ Group } & $\begin{array}{c}\text { DC units } \\
\text { of act./mg } \\
\text { of protein) }\end{array}$ & $\begin{array}{c}\text { MDA (units } \\
\text { of act./mg } \\
\text { of protein) }\end{array}$ \\
\hline Falsely operated & $13.68 \pm 0.51$ & $7.03 \pm 0.09$ \\
\hline Negative control & $52.06 \pm 1.57 \#$ & $14.54 \pm 0.33 \#$ \\
\hline Mexidol & $24.36 \pm 0.96^{*}$ & $8.79 \pm 0.2^{*}$ \\
\hline PIR-10 & $23.82 \pm 1.43^{*}$ & $9.27 \pm 0.68^{*}$ \\
\hline
\end{tabular}

Note: \# means the figure is authentic against falsely operated rats $(\mathrm{P}<0.05) ; *$ means the figure is authentic against rats from the negative control group $(\mathrm{P}<0.05)$.
Therapy with Mexidol led to a substantial decrease in DC (by 53.2\%, $\mathrm{P}<0.05$ ) and MDA (by 39.5\%) in comparison with rats from the negative control group. Treatment with PIR-10 substance also resulted in lower concentrations of lipid peroxidation products; thus, DC went down by $54.2 \%(\mathrm{P}<0.05)$, and MDA, by $36.2 \%$ $(\mathrm{P}<0.05)$ in comparison with rats from the negative control group. And we didn't detect any statistically significant discrepancies between rats who were given either Mexidol or PIR-10 substance.

As we can see from Figures 1 and 2, introduction of Mexidol led to greater activity of all antioxidant protection enzymes in comparison with the rats from the negative control group; thus, SOD activity increased by $20.4 \%$ $(\mathrm{P}<0.05)$; GP activity, by $34.0 \% \quad(\mathrm{P}<0.05)$; catalase activity, by $37.2 \%(\mathrm{P}<0.05)$; and it is well in line with literature data [22]. But still, this increased superoxide dismutase activity and glutathione peroxidase activity was significantly lower than in falsely operated animals, by $9.9 \%$ and $33.0 \%$, respectively.

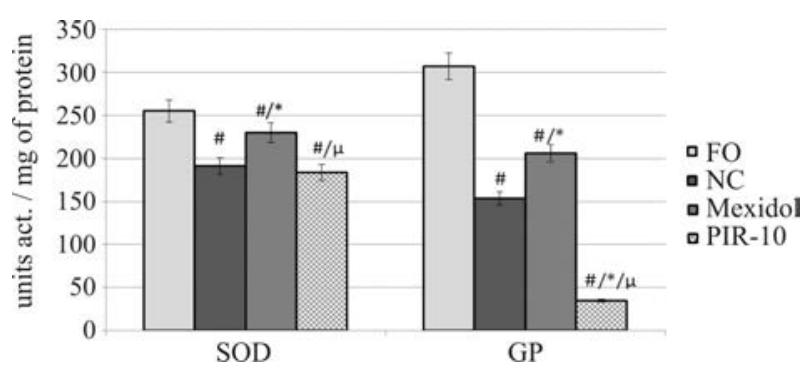

Figure 1. Influence exerted by Mexidol and PIR-10 on superoxide dismutase and glutathione peroxidase concentration in the postnuclear fraction of rats' brain homogenate against focal ischemia

Note: \# means the figure is authentic against falsely operated rats $(\mathrm{P}<0.05)$; ${ }^{*}$ means the figure is authentic against rats from the negative control group $(\mathrm{P}<0.05) ; \mu$ means the figure is authentic against rats that were given Mexidol $(\mathrm{P}<0.05)$.

Introduction of the examined substance PIR-10 led to a decrease in concentrations of endogenous AOP enzymes. Thus, SOD concentrations amounted to $183.46 \pm 2.88$ units of act./mg of protein; it wasn't authentically different from the value detected for rats from the 
negative control group and by $28.2 \%(\mathrm{P}<0.05)$ and $20.2 \%(\mathrm{P}<0.05)$ lower than in falsely operated rats and rats that were given Mexidol, respectively. Glutathione peroxidase in rats that were given PIR-10 went down authentically against animals from all other groups; against falsely operated rats, by $88.9 \%(\mathrm{P}<0.05)$; against the negative control, by $77.6 \%(\mathrm{P}<0.05)$; against rats that were given Mexidol, by $83.2 \%(\mathrm{P}<0.05)$. Catalase was as active as in falsely operated rats and amounted to $0.33 \pm 0.01 \mathrm{nmol} / \mathrm{min} / \mathrm{mg}$ of protein. This parameters was lower by $57.7 \%$ $(\mathrm{P}<0.05)$ than in rats from the negative control group, and by $69.2 \%(\mathrm{P}<0.05)$ against rats that were given Mexidol.

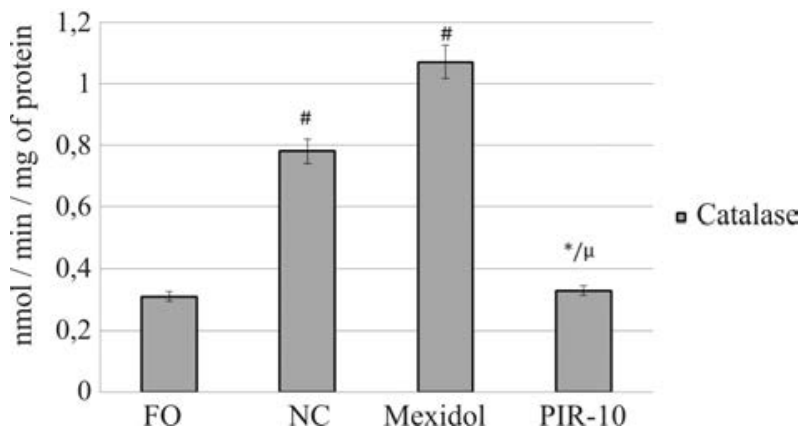

Figure 2. Influence exerted by Mexidol and PIR-10 on catalase activity in the post-nuclear fraction of rats' brain homogenate against focal ischemia.

Note: \# means the figure is authentic against falsely operated rats $(\mathrm{P}<0.05) ; *$ means the figure is authentic against rats from the negative control group $(\mathrm{P}<0.05) ; \mu$ means the figure is authentic against rats that were given Mexidol $(\mathrm{P}<0.05)$.

The obtained results can indicate that superoxide dismutase exerts its impacts on free oxygen forms thus transforming them into hydrogen peroxide [23], then glutathione peroxidase and catalase are likely to neutralize this hydrogen peroxide [24], and it can lead to lower concentrations of AOP enzymes against a decrease in formation of free radicals themselves. Analysis of experimental data is also confirmed by lower concentrations of lipid peroxidation products against introduction of
PIR-10 substance. Given all the above-mentioned, we can conclude that the examined substance PIR-10 exerts its impacts on formation of free radicals but at the same time it doesn't activate the antioxidation system itself. And the reference substance Mexidol exerts its antioxidant impacts due to reinforcing antioxidation protection enzymes [25, 26].

\section{Conclusions.}

1. Experimentally simulated focal cerebral ischemia causes pro/antioxidant imbalance that is confirmed by an increase in concentrations of DC (by $280.6 \%(\mathrm{P}<0.05))$ and MDA (by $106.8 \%(\mathrm{P}<0.05)$ ), a decrease in concentrations of AOP enzymes (SOD by $25.2 \%(\mathrm{P}<0.05)$, GP by $49.9 \%(\mathrm{P}<0.05))$ and an increase in catalase concentration $151.6 \%$ $(\mathrm{P}<0.05)$ in rats who didn't get any pharmaceutical support against falsely operated rats.

2. Introduction of Mexidol in a dose equal to $50 \mathrm{mg} / \mathrm{kg}$ results in activation of antioxidation protection system and it becomes obvious through a increase in SOD concentration by $20.4 \%(\mathrm{P}<0.05)$, GP concentration by $34.0 \%$ $(\mathrm{P}<0.05)$, and catalase concentration by $37.2 \%$ $(\mathrm{P}<0.05)$, as well as through a decrease in concentrations of lipid peroxidation products (DC by $53.2 \%(\mathrm{P}<0.05)$ and MDA by $39.5 \%)$ against animals from the negative control group.

3. Introduction of the examined substance PIR-10 leads to a decrease in concentrations of lipid peroxidation products (MDA by 36.2\% $(\mathrm{P}<0.05)$, DC by $54.2 \%(\mathrm{P}<0.05))$ against rats from the negative control group but it doesn't cause any growth in concentrations of AOP enzymes. We can assume that this substance exerts antioxidation impacts as it reduces hyperproduction of free radicals without any effects produced on AOP enzymes themselves.

Funding. The research was not granted any sponsor support.

Conflict of interests. The authors state there is no any conflict of interests. 


\section{References}

1. Luk'yanova L.D. Sovremennye problemy adaptatsii k gipoksii. Signal'nye mekhanizmy i ikh rol' $\mathrm{v}$ sistemnoi regulyatsii [Modern problems of adaptation to hypoxia. Signal mechanisms and their role in system regulation]. Patologicheskaya Fiziologiya, 2011, no. 1, pp. 3-19 (in Russian).

2. Lang J.D. Oxidant-antioxidant balance in acute lung injury. Chest, 2002, vol. 122, no. 6, pp. 314-320.

3. Myshkin V.A., Gulyaeva I.L., Ibatullina R.B. Vliyanie aktoprotektorov na perekisnoe okislenie lipidov i sostoyanie membran eritrotsitov u krys pri otravlenii karbofosom [The influence of aktoprotektors on lipid peroxidation and the status of erythrocyte membranes in rats with Malathion poisoning]. Patologicheskaya fiziologiya i eksperimental'naya terapiya, 2004, no. 3, pp. 52-58 (in Russian).

4. Rodrigo R., Fernández-Gajardo R., Gutiérrez R., Matamala J.M., Carrasco R. [et al.]. Oxidative stress and pathophysiology of ischemic stroke: novel therapeutic opportunities.CNS \& Neurological Disorders - Drug Targets, 2013, vol. 12, pp. 698-714.

5. Solov'eva E.Yu., Mironova O.P., Baranova O.A. [et al.]. Svobodnoradikal'nye protsessy i antioksidantnaya terapiya pri khronicheskoi ishemii mozga [Free radical processes and antioxidant therapy in chronic brain ischemia]. Zhurnal nevrologii i psikhiatrii, 2008, no. 6, pp. 98-104 (in Russian).

6. Maslyukova A.V., Tomilova I.K., Baklushina E.A. Biokhimicheskie markery perenesennogo ostrogo narusheniya mozgovogo krovoobrashcheniya [Biochemical markers of the postponed intense violation of brain blood circulation]. Vestnik Ivanovskoi gosudarstvennoi meditsinskoi akademii, 2015, no. 1, pp. 37-44 (in Russian).

7. Kofler J, Hurn P.D, Traystman R.J. SOD1 overexpression and female sex exhibit region-specific neuroprotection after global cerebral ischemia due to cardiac arrest. Journal of Cerebral Blood Flow and Metabolism, 2005, vol. 25, pp. 11-30.

8. Lugovoi I.S., Kodonidi I.P., Voronkov A.V., Shabanova N.B., Kodonidi M.I. Tselenapravlennyi sintez n-peptidnykh proizvodnykh pirimidin-4(1n)-ona, obladayushchikh tserebroprotektornymi svoistvami [Purposeful synthesis of n-peptide derivatives of pyrimidine-4(1h)-on, having cerebroprotective properties]. Zdorov'e i obrazovanie v XXI veke, 2017. vol. 19, no. 8, pp. 195-199 (in Russian).

9. El-Mekabaty A. Synthesis and Antioxidant Activity of Some New Heterocycles Incorporating the Pyrazolo-[3,4-D]Pyrimidin-4-One Moiety. Chemistry of Heterocyclic Compounds, 2015, no. 50, 1698 p.

10. El-Mekabaty A., Habib O.M.O., Moawad E.B., Hasel A.M. Synthesis and Antioxidant Activity of New Pyrazolo[1,5-a]Pyrimidine Derivatives Incorporating a Thiazol-2-yldiazenyl Moiety. Journal of Heterocyclic Chemistry, 2015, vol. 53, no. 6, pp. 1820-1826.

11. Inchina V.I., Korshunova A.B., Prosvirkina I.A. Sravnitel'naya otsenka nekotorykh effektov proizvodnykh 3-oksipiridina i pirimidina $\mathrm{v}$ eksperimente [Comparative evaluation of some effects of 3-hydroxypyridine and pyrimidine derivatives in the experiment]. Vestnik novykh meditsinskikh tekhnologii, 2010, vol. 17, no. 3, pp. 158-160 (in Russian).

12. Voronkov A.V., Shabanova N.B., Pozdnyakov D.I., Lugovoi I.S., Kodonidi I.P. Vliyanie novykh proizvodnykh pirimidin-4(1n)-ona na psikhoemotsional'nyi disbalans i nekotorye narusheniya energeticheskogo obmena u krys na fone ishemii golovnogo mozga [The impact of new derivatives of pyrimidine- $4(1 \mathrm{H})$-she's on the psycho-emotional imbalance and certain violations of energy metabolism in rats on the background of cerebral ischemia]. Sovremennye problemy nauki i obrazovaniya, 2017, no. 5. Available at: http://www.science-education.ru/ru/article/view?id=26738 (25.05.2018) (in Russian).

13. Bederson J.B., Pitts L.H., Tsuji M., Nishimura M.C., Bartkowski H. Rat Middle Cerebral Artery Occlusion: Evaluation of the Model and Development of a Neurologic Examination. Stroke, 1986, vol.17, pp. 472-476. DOI: 10.1161/01.STR.17.3.472

14. Vladimirov Yu.A., Archakov A.I. Perekisnoe okislenie lipidov v biologicheskikh membranakh [Perekisny oxidation of lipids in biological membranes]. Nauka Publ., 1972, 252 p. (in Russian).

15. Gavrilov V.B., Mishkorudnaya M.I. Spektrofotometricheskoe opredelenie soderzhaniya gidroperekisei lipidov v plazme krovi. Laboratornoe delo, 1983, no. 3, pp. 33-35 (in Russian).

16. Stal'naya I.D., Garishvili T.G. Metod opredeleniya malonovogo dial'degida s pomoshch'yu TBK [Metod of definition of low-new dialdehyde by means of TBK]. Sovremennye metody v biokhimii. Moscow, Medicina Publ., 1977, pp. 44-46 (in Russian).

17. Chumakov V.N., Osinskaya L.F. Kolichestvennyi metod opredeleniya aktivnosti tsink-med'zavisimoi superoksiddismutazy $\mathrm{v}$ biologicheskom materiale [A quantitative method of determination of 
activity zinc - copper - dependent superoxide dismutases in biological material]. Voprosy meditsinskoi khimii, 1977, no. 5, pp. 712-716 (in Russian).

18. Korolyuk M.A. Metod opredeleniya aktivnosti katalazy [Method of determination of activity of a catalase]. Laboratornoe delo, 1988. no. 1, pp. 16-19 (in Russian).

19. Prohaska J.R. The glutathione peroxidase activity of glutathione-S-transferases. Biochimocaet Biophysica Acta, 1980, vol. 611, pp. 87-98.

20. Zhang Y.B., Kan M.Y., Yang Z.H., Ding W.L., Yi J., Chen H.Z., Lu Y. Neuroprotective effects of N-stearoyltyrosine on transient global cerebral ischemia in gerbils. Brain Research, 2009, no. 1287, pp. 146-56.

21. Trofimenko A.I., Levichkin V.D., Pavlyuchenko I.I., Kade A.X., Okhremenko O.S., Zanin S.A. Kharakteristika sdvigov $\mathrm{v}$ sisteme pro-/antioksidanty u krys s model'yu ostroi lokal'noi tserebral'noi ishemii [Characteristics of shifts in the Pro-/antioxidants system in rats with a model of acute local cerebral ischemia]. Fundamental nye issledovaniya, 2013, vol. 4, no. 9, pp. 683-686 (in Russian).

22. Povarova O.V. Farmakologicheskaya korrektsiya ishemicheskogo porazheniya golovnogo mozga krys pri okklyuzii srednei mozgovoi arterii [Pharmacological correction of ischemic brain damage in rats with occlusion of the middle cerebral artery]. Moscow, 2003, 26 p. (in Russian).

23. Voronkov A.V., Pozdnyakov D.I., Khuri E.I., Rybalko A.E. Sravnenie antioksidantnoi aktivnosti meksidola pri povrezhdeniyakh golovnogo mozga razlichnogo geneza v eksperimente [Comparison of antioxidant activity of Mexidol in brain damage of different Genesis in the experiment]. Sovremennye problemy nauki i obrazovaniya, 2016, no. 6. Available at: http://science-education.ru/ru/article/view?id $=25392$ (25.05.2018) (in Russian).

24. D'yakova I.N. Eksperimental'noe issledovanie tserebroprotektornykh svoistv ferulovoi kisloty v usloviyakh ishemii mozga [Experimental study of cerebroprotective properties of ferulic acid in ischemia of the brain]. Pyatigorsk, 2007, 24 p. (in Russian).

25. Avdeeva Yu.A., Kalutskii P.V., Korolev V.A., Medvedeva O.A., Verevkina N.A., Kalutskii A.P. Korrektsiya posledstvii okislitel'nogo stressa $\mathrm{v}$ usloviyakh eksperimental'nogo disbioza s primeneniem meksidola [Correction of the effects of oxidative stress in experimental dysbiosis using Mexidol]. Vestnik voronezhskogo gosudarstvennogo universiteta, 2017, no. 4, pp. 43-47 (in Russian).

26. Inchina V.I., Raginov I.S., Chairkin I.N., Kostychev N.A., Korshunova A.B. Vliyanie razlichnykh rezhimov vvedeniya nekotorykh proizvodnykh 3-gidroksipiridina $\mathrm{v}$ terapii ostroi ishemii golovnogo mozga u belykh krys na fone eksperimental'nogo sakharnogo diabeta [The effect of different modes of administration of some 3-hydroxypyridine derivatives in the treatment of acute brain ischemia in white rats with experimental diabetes mellitus]. Uchenye zapiski Kazanskogo universiteta. Seriya: Estestvennye nauki, 2010, vol. 152, no. 1, pp. 155-165 (in Russian).

Voronkov A.V., Shabanova N.B. Pro/antioxidant activity of a new PIR-10 substance (pyrimidine derivative) under experimentally simulated focal cerebral iscemia in rats. Health Risk Analysis, 2019, no. 1, pp. 103-108. DOI: 10.21668/health.risk/2019.1.11.eng

Received: 23.01 .2019

Accepted: 11.03 .2019

Published: 30.03.2019 
UDC 364.272

DOI: $10.21668 /$ health.risk/2019.1.12.eng

\title{
EPIDEMIOLOGIC ASPECTS RELATED TO TOBACCO SMOKING AS RISK FACTORS FOR FEMALE WORKERS EMPLOYED IN RETAIL TRADE
}

\author{
T.N. Inglik, N.M. Chernyavskaya, L.B. Aybazova \\ Amur State University of Humanities and Pedagogy, 17/2 Kirova Str., Komsomolsk-na-Amure, 681000, \\ Russian Federation
}

Tobacco smoking is widely spread among population and it results in unfavorable forecasts as regards population health; it is truly a vital social problem in Russia. We chose the following research object: female workers employed by a retail network which consisted of both grocery stores and catering outlets. Our research goal was to examine epidemiologic aspects related to tobacco smoking; the research was performed among workers via anonymous questioning. As a result, we detected that $60 \%$ of workers smoked. The share was even greater among women aged 40-50 as $77.8 \%$ of them had this bad habit. We also detected that women in the examined sampling tended to start smoking at an earlier age than it had used to be; the trend is quite similar to those observed across Russia. We investigated how aware our respondents were of negative consequences tobacco smoking could lead to; the investigation revealed that non-smoking respondents were better aware that smoking was a hazardous and really bad habit than those who smoked. We examined peculiarities that we detected in prevalence of false ideas among women depending on their smoking behavior and age. Smoking women aged 30-40 had very little knowledge on the subject.

We assessed intensity and a type of smoking and revealed that only each fifth respondent smoked only occasionally while others smoked cigarettes in average or large numbers. $33.3 \%$ of smoking women younger than $30,14.3 \%$ of women aged 40-50, and 10\% of women aged 30-40 had strong nicotine dependence. A desire to get some support in a complicated psycho-emotional situation was a prevailing motive for tobacco smoking among the respondents; it could be related both to their work activities and to weaker behavioral regulation. The research also revealed that non-smokers supported antismoking measures more actively.

Key words: workers employed in retail trade, prevalence and motives for smoking, negative consequences of smoking, types of nicotine dependence, anti-smoking measures

In the Russian Federation an average number of people employed in retail trade and catering has grown by more than $18.6 \%$ from 2010 to 2016 and amounted to 11.5 million people in that year ${ }^{1}$. Retail trade provides jobs for $20 \%$ working women and it is the highest figure among all the branches of the country economy [1]. Given that, examination of the branch peculiarities and minimization of risk factors that cause health losses by female workers allows to consider issues and solve tasks in the sphere on a national scale.

Tobacco smoking is known to be a behavioral risk factor that causes, together with other factors, occurrence of chronic noninfectious diseases; these diseases lead to huge economic losses for the state and thus impede its stable development. Thus, the

(C) Inglik T.N., Chernyavskaya N.M., Aybazova L.B., 2019

Tatyana N. Inglik - Candidate of Pharmaceutical Sciences, Associate Professor at Department for Life Safety and Natural Sciences (e-mail: t.inglik@yandex.ru; tel.:+7 (914) 178-19-45, ORCID: https://orcid.org/0000-0002-0723-1667).

Nadezhda M. Chernyavskaya - Candidate of Biological Sciences, Associate Professor, Head of Department for Life Safety and Natural Sciences (e-mail: nadya-chery@yandex.ru; tel.: +7 (914) 189-61-43, https://orcid.org/0000-0001-6370-5874).

Larisa B. Aybazova - Senior lecturer at Department for Life Safety and Natural Sciences (e-mail: aibazovm@mail.ru; tel.: +7 (962) 287-47-35, https://orcid.org/0000-0002-5941-0130).

${ }^{1}$ Labor and employment in Russia. 2017: Statistical data collection / Rosstat. - V78. - M., 2017. - 261 p. 
WHO Framework Convention on Tobacco Control (2003) considers tobacco smoking pandemic to be a global issue that causes serious disastrous outcomes for people's health and induces negative social, economic, and ecologic processes all the world as well ${ }^{2}$.

Negative impacts exerted on human health by tobacco smoke are a key concern for medical experts; tobacco-related diseases are a greatest threat for public health care. As per data provided by the RF Ministry for Public Healthcare and Social Development, annually more than 270 thousand people die due to tobacco smoking; smoking-related death cases among middle-age population in the RF account for $36 \%$ among men and for $7 \%$ among women. Smoking is one of the most significant risk factors that cause occurrence of cardiovascular, respiratory, and oncologic diseases and are basic causes of death. Thus, up to $90 \%$ of all the lung cancer cases, $75 \%$ of chronic obstructive lung disease cases, $25 \%$ of all the ischemic heart diseases cases, and adverse clinical course of tuberculosis are related to smoking [2].

Nowadays, a correlation between impacts exerted by tobacco smoke and reproductive function disorders is well proven; these disorders include a decrease in fertility, early menopause, menstrual cycle disorders, and cervical carcinoma risk (especially when a girl starts smoking at a rather young age) [3].

Smoking by pregnant women increases perinatal morbidity and causes neonatal adaptation disorders [4]. Nicotine as a neurotoxic substance causes a delay in development of the central nervous system and fetal development; greater risk of crib death and risk of psychoneurological and functional disorders in children born from smoking parents [5].

However, despite all these concerns by medical society, smoking is still widely spread. Thus, according to statistical data provided by the WHO, in 20131.1 billion people all the world smoked, including 950 million man and 177 million women; so, as we can see, total number of smokers amounted to $21 \%$ of the overall adult population in the world [6].

Unfortunately, in Russia smoking has been and still remains one of the most widely spread bad habits; a significant part of the country population has it. In $201038.4 \%$ of the country citizens smoked; $61.3 \%$ men and $19.4 \%$ women who are older than 15 are tobacco smokers. As per the WHO data collected in 2013, 59.8\% men and $22.7 \%$ women in Russia were smokers [7, 8].

Russian Public Opinion Research Center (RPORC) performed a questioning on the issue in 2017; according to its results, smokers account for approximately $32 \%$ of the country population. We can note that a number of smokers tends to decrease slightly, both in Russia and in some post-Soviet countries [9, 10]. However, a number of smoking citizens in the country is still high and amounts to more than 44 million people. Also, in spite of a certain decrease in volume of cigarettes sales over recent years, cigarettes consumption per capita in Russia remains one of the highest in Europe and amounted to 2,227 cigarettes in $2014^{3}$.

A number of female smokers in Russia tends to be growing, and this fact is especially alarming. Thus, if in 1992 only 7\% women in Russia smoked, the figure grew to $19 \%$ in 2008, and even to $30 \%$ in megacities. Prevalence of tobacco smoking among women has grown by 3.3 times since 1980 ties $^{3}$.

We analyzed literature data on prevalence of tobacco smoking among various age groups and revealed that the greatest share of female smokers was detected among women aged 1524 and 25-39 where it accounted for $29.8 \%$ (in both groups). each fifth Russian woman aged 40-54 smoked (19.6\%); each tenth, among those aged 55-69 (9.4\%) [11]. On the other hand, The Civic Chamber of the Russian Federation issued a report where it stated that a number of smoking women has grown recently not only among young women (aged 20-39)

\footnotetext{
${ }^{2}$ The WHO Framework Convention on Tobacco Control // The World Health Organization. - Geneva, 2003. - URL: http://apps.who.int/iris/bitstream/10665/42811/4/9789244591017_rus.pdf?ua=1 (date of visit June 18, 2018).

${ }^{3}$ Russian statistical annual. 2015: Statistical data collection / Rosstat. - M.: rosstat, 2015. - 728 p.
} 
but also among older ones, by 4.7 times among women aged 40-47, and by 3.7 times, among those aged $50-59^{4}$.

A lot of researchers note that a risk of tobacco smoking dependence is closely related to a social and economic status (education, occupation, income level, and availability of material wealth $)^{4}$ [12]. Thus, epidemiologic research performed in Moscow revealed that prevalence of smoking amounted to $33.7 \%$ among women with higher education, and to $50 \%$ among those without it.

Research on prevalence of tobacco smoking among population in Khabarovsk region revealed that $20-50 \%$ women who lived on the examined territory were familiar with it. Tobacco smoking occurred especially frequently among women living in rural districts (42.4\%), and women employed at industrial enterprises (38.7\%). Prevalence of tobacco smoking among female medical workers, students, and school students amounted to $18.9 \%, 23.3 \%$, and $18.1 \%$ correspondingly [13].

Prevalence of behavioral risk factors, addiction to psychoactive substances in particular, is a most significant medical and social indicator that characterizes not only population health, but also a demographic potential of any state. In relation to that, giving up smoking allows to prevent deaths and certain diseases and, therefore, leads to longer life span of the population.

In 2008 Russia joined the WHOP Framework Convention on Tobacco Control aimed at fighting against tobacco smoking; the Convention includes such important activities in the sphere as protection of people from impacts by tobacco smoke; regulation of tobacco products structure; regulation of package and marking for tobacco products; warning people that tobacco is hazardous; prohibition of tobacco advertising; control over illegal trade in tobacco products; prohibition to sell tobacco to underaged and by under-aged. As the country joined the Convention, it gave grounds for issuing a number of anti-tobacco regulatory and legislative acts.
Implementation of such activities as fighting against illegal trade in tobacco products and prohibition to sell tobacco products to under-aged and by under-aged is to a great extent determined by conscience and honesty of retail trade workers. But on the other hand, smoking behavior pursued by retail trade workers, with women and young people accounting for a big share of them, can be considered as "tobacco products advertising" especially for children and teenagers. Besides, if retail trade workers smoke, it causes profit losses to a company and deteriorates its image, in particular, due to unauthorized "smoke breaks" and absence of workers at their workplaces. Prevalence of smoking among retail trade workers hasn't been properly studied.

Given all that, our research goal was to study epidemiological aspects of tobacco smoking among workers employed by a retail network in Komsomolsk-na-Amure.

Data and methods. 204 women aged from 18 to 48 took part in our research; they were all employed at grocery stores that belonged to retail trade companies located in the city (Bitte, Amba). Average age amounted to 34.5. The respondents were divided into three age groups, 18-30 (the 1st group, average age being 23.8); 30-40 (the 2nd group, average age being 35.7); and 40-50 (the 3rd group, average age being 44.2).

We used tests and a questioning in our research. All the questions included into the questionnaire could be divided into four basic groups as per their subject matters: examining prevalence of smoking, examining respondent's awareness about medical and social consequences of tobacco smoking, examining prevalence of wrong beliefs (myths) about tobacco among respondents, determining attitudes towards anti-tobacco measures among respondents.

To examine what attitudes towards smoking prevailed among respondents, we applied a test developed by V.A. Khriptovich where they had to express to what extent they agreed

\footnotetext{
${ }^{4}$ Tobacco smoking epidemic in Russia: causes, consequences, ways to control: A report by The RF Civic Chamber [web-source]. - M., 2009. - URL: https://www.oprf.ru/files/tabakokurenie.doc (date of visit June 20, 2018).
} 
or disagreed with each out of 40 statements according to a 5-score scale [14]. Assessment of the test results allows to determine whether a respondent has a negative, neutral, or positive attitude towards smoking.

Smoking respondents were offered the following tests: Fagerstrom Test for Nicotine Dependence, Horn test "Value your relations with cigarettes", "Smoking behavior type" and "Do you want to quit smoking?" (J. Lagrue) $[15,16]$. Nicotine dependence as per Fagerstrom test is estimated as per a number of cigarettes a person smokes a day and peculiarities of smoking behavior in different situations.

Motivation to smoke was estimated as per Horn test; respondents were offered to express their agreement or disagreement with 18 statements according to a 5-score scale; each three of 18 statements correspond to a specific motivation type ("Stimulation", "Pleasure of the act", "Relaxation", "Anxiety support", "Absolute need" and "Acquired habit"). An extent to which a motivation type prevailed was determined as per a sum of scores given to it (from 0 to 15 ); up to 7 scores meant motivation was weak, 7-10 scores meant average motivation, and higher than 10 scores meant motivation was strong.

According to "Smoking behavior type" test developed by J. Lagrue, a type of a smoker and addiction are determined depending on quantity of cigarettes a person smokes a day. "Do you want to quit smoking?" test consists of 4 questions and allows to reveal how eager a person is to give up smoking.

Basic results and discussion. We examined the sampling and revealed that at present $60 \%$ female workers employed by selected companies were smokers. $32.5 \%$ out of $40 \%$ female workers who didn't smoke at the moment of the research had experienced tobacco smoking in their past, and it had been once/several times or casual smoking. However they had somehow lost any interest in it, had felt themselves bad, or had thought about adverse effects of smoking, and it had made them give it up. Only $7.5 \%$ respondents stated they had never tried tobacco in their life.
Women who were active smokers prevailed in each age group. Thus, they accounted for $58.3 \%$ in age group younger than 30 ; $52.6 \%$, among women aged $30-40$; and $77.8 \%$, among those who were older than 40 . In relation to that we can estimate prevalence of smoking among this particular sampling as being very high. We should note that the older age category made of women born in the late 60ties - early 70ties last century was involved into smoking to a greater extent that younger age group despite the fact that they were born in the Soviet Union times when smoking was not so widely spread as it is now.

We detected at what age the respondents had first tried smoking; the results are given in Table 1. As we can see from it, smokers aged 40-50 started smoking at older ages. Thus, almost each second respondent (42.8\%) in the senior age group and only each tenth $(10 \%)$ aged 30-40 first started smoking when they were 18 or older. We didn't detect any "late" starters among women younger than 30 .

\section{Table 1}

Distribution of respondents depending on the age when they first tried smoking

\begin{tabular}{|l|c|c|c|}
\hline \multirow{2}{*}{$\begin{array}{c}\text { Age of a first } \\
\text { cigarette }\end{array}$} & $40-50$ & $30-40$ & $\begin{array}{c}\text { Younger } \\
\text { than 30 }\end{array}$ \\
\cline { 2 - 4 } & - & - & 28.6 \\
\hline $11-12$ & 28.6 & 70 & 57.1 \\
\hline $13-14$ & 28.6 & 20 & 14.3 \\
\hline $16-17$ & 42.8 & 10 & - \\
\hline 18 and older & \multicolumn{3}{|c|}{ Quantity, \% } \\
\hline
\end{tabular}

$28.6 \%$ in the youngest age group, unlike the two others, first tried smoking at such an early age as 11-12. Therefore, we can state that the first cigarette tends to be taken at an earlier age in the examined sampling depending on an age group, and it goes in line with trends detected in the country [17].

Poor awareness about smoking-related hazards and wrong beliefs (myths) that make tobacco hazards not so serious, but smoking, on the contrary, more attractive are leading factors for greater prevalence of tobacco smoking.

Results on respondents' awareness about negative effects produced by tobacco are given 
in Table 2. Their analysis revealed that both smoking respondents and those who don't have this bad habit are well aware about negative outcomes of smoking. Respondents fully understand that smoking can cause malignant neoplasms and cardiovascular diseases; it may be due to the fact that this knowledge has been actively promoted in mass media. Besides, graphic images on packs of cigarettes provide a smoker with detailed and visually understandable information about adverse outcomes of tobacco smoking.

However, the obtained results prove that respondents' awareness about smoking-related hazards is only superficial. Thus, most respondents don't think there is a direct link between chemical structure of components contained in tobacco smoke and carcinogenic risks. It is interesting to note that most smoking and nonsmoking women are not aware of negative effects produced by tobacco on the reproductive system and on children's physical and mental development.

A comparative analysis of awareness about smoking-related hazards as per different age groups revealed that in general smoking women aged under 30 and older than 40 were better aware than women aged 30-40; the latter had to grow up under the least favorable social conditions that existed in that most adverse period in the country development. Young women turn out to be the best informed in most cases. Thus, all the examined women who were younger than 30 knew that smoking caused lung and esophagus cancer; as for groups 2 and 3, about $80 \%$ in these groups were aware of this fact.

In some cases women aged 40-50 were better aware of some facts than their younger counterparts. In particular, $90 \%$ examined women aged 40-50 knew that smokers suffered from cardiac infarction more frequently against $75 \%$ among those younger than 30 and only $63.2 \%$ of those aged $30-40$. We can assume that this better awareness among older women about a correlation between heart diseases and smoking is partly due to their life experience as cardiac infarctions and chronic heart diseases frequently occur exactly at this age (after 40).

There are a lot of myths that underestimate smoking-related hazards or create ideas on its potential benefits for health; we examined prevalence of such myths among our respondents and you can see the results in Table 3. Their analysis revealed that in general

Table 2

Awareness about smoking-related hazards among smoking and nonsmoking women

\begin{tabular}{|l|c|c|}
\hline \multicolumn{1}{|c|}{$\begin{array}{c}\text { Negative consequences } \\
\text { of smoking }\end{array}$} & \multicolumn{2}{c|}{ Number, \% } \\
\cline { 2 - 3 } & nonsmoking & smoking \\
\hline Smoking causes lung and esophagus cancer & 87.5 & 83.3 \\
\hline Smokers suffer from cardiac infarction more frequently & 68.8 & 75 \\
\hline $\begin{array}{l}\text { Smoking causes greater risk of diseases in eyes, hearing apparatus, teeth, } \\
\text { gums, and blood }\end{array}$ & 62.5 & 41.7 \\
\hline Smoking women run greater risk of cervical carcinoma and miscarriages & 68.8 & 29.2 \\
\hline Smoking mothers often give birth to children with congenital malformations & 68.8 & 50 \\
\hline Smoking men suffer from impotency and infertility more frequently & 43.8 & 37.6 \\
\hline $\begin{array}{l}\text { When a smoker takes a puff, about 1,200 hazardous substances are formed, } \\
\text { including 43 carcinogens that can cause cancer }\end{array}$ & 31.3 & 20.8 \\
\hline A smoker's brain always suffers from oxygen starvation & 75 & 62.5 \\
\hline $\begin{array}{l}\text { Smoking often causes bronchial asthma, bronchitis, lip, tongue, larynx, and } \\
\text { trachea cancer }\end{array}$ & 75 & 70.8 \\
\hline $\begin{array}{l}\text { A smoker's heart wears more rapidly as it has to contract 12-15 thousand } \\
\text { times more }\end{array}$ & 56.3 & 66.7 \\
\hline $\begin{array}{l}\text { Children born by smoking mothers often suffer from delayed development; } \\
\text { they are worse in reading at the age of 7 and in comprehending texts } \\
\text { and solving mathematical tasks at 10 than their peers }\end{array}$ & 18.75 & 8.3 \\
\hline
\end{tabular}


Prevalence of myths about tobacco among the examined women

\begin{tabular}{|l|c|c|c|c|c|}
\hline \multirow{2}{*}{ Statements } & \multicolumn{5}{c|}{ Number, \% } \\
\cline { 2 - 6 } & Nonsmoking & Smoking & Younger than 30 & $30-40$ & $40-50$ \\
\hline Everybody smokes & 18.8 & 12.5 & 28.6 & 10 & - \\
\hline All adults smoke & 6.30 & 8.3 & 14.3 & 10 & - \\
\hline It is easy to quit & 37.5 & 16.7 & 14.3 & 37 & - \\
\hline $\begin{array}{l}\text { Smoking is hazardous only for those who } \\
\text { Smoke }\end{array}$ & - & 12.5 & 14.3 & 20 & - \\
\hline Smoking helps to keep slim & - & 4.2 & - & 10 & - \\
\hline Smoking helps to remove anxiety (stress) & 37.5 & 70.8 & 28.6 & 74 & 71.4 \\
\hline Smoking is harmless & - & - & - & - & - \\
\hline Smoking without puffs is harmless & - & - & - & - & - \\
\hline
\end{tabular}

such myths didn't tend to be widely spread among the examined respondents as opposed to teenagers who are more susceptible to wrong beliefs [18]. In particular, none of our respondents agree with the following statements: "smoking is harmless" and "smoking without puffs is harmless".

When we compared prevalence of myths about tobacco smoking among nonsmoking and smoking women, we revealed that some myths were widely spread only among smokers, including a wrong belief that smoking helps to keep fit and not put on weight. A myth that smoking helps to overcome stresses is the most widely spread exactly among smoking women as $70.8 \%$ smoking women agreed with that statement. And on the contrary, a myth about easiness of giving that bad habit up is the most widely spread among nonsmoking women.

Our analysis on prevalence of myths about tobacco smoking as per age groups confirmed that respondents aged 30-40 were the most poorly aware of its negative outcomes. Thus, each tenth respondent in this age group tended to underestimate hazards related to passive smoking, and 37\% respondents were sure it was quite easy to give it up. $74 \%$ respondents aged 30-40 believed smoking could help to ease strain. It is interesting to note that smoking women aged 40-50 didn't believe in all the above mentioned myths except one about easing strain.

Our examination on respondents' attitudes towards smoking revealed that in general both smokers and non-smokers tended to have either negative or neutral attitudes towards it. We didn't reveal any positive attitudes towards tobacco smoking among our respondents. However, all the nonsmoking respondents from the 1 st and 3rd group had negative attitudes towards smoking, while at the same time only $78 \%$ respondents didn't approve of it in the 2nd group. A number of respondents among smokers in all the three groups who didn't have any negative attitude towards smoking amounted to $24 \%$, $42 \%$, and $33 \%$ correspondingly. So, smokers tended to have more positive attitude towards smoking than non-smoking respondents. However, those non-smokers who are neutral to smoking can try it in this or that situation.

We determined a nicotine dependence degree in smoking women; it was revealed that nicotine dependence was absent in each second smoking woman younger than 30 and aged 30-40, and only in each fourth respondent aged 40-50 (Table 4). On the other hand, strong nicotine dependence was detected in each third smoking woman from the 1st group, in each seventh woman, from the 3rd group, and in each tenth woman form the 2 nd group. A great number of women with strong nicotine dependence in the 1st group can be caused, in particular, by younger age at which they started smoking.

Deliverance from nicotine dependence is known to be a prevention medicine task that is just as important for reducing risks of cardiovascular diseases as correction of hyperlipidemia, hypercholesterolemia, arterial hypertension, or hypodynamia. The research re- 
vealed that $43.5 \%$ smoking respondents with average and strong nicotine dependence could receive recommendations to take nicotinereplacing medications. Respondents with weak nicotine dependence can give up smoking without any drug therapy.

Table 4

Distribution of respondents as per nicotine dependence degree $(\%)$

\begin{tabular}{|l|c|c|c|c|}
\hline \multirow{2}{*}{$\begin{array}{c}\text { Nicotine } \\
\text { dependence } \\
\text { degree }\end{array}$} & \multicolumn{2}{|c|}{ Examined groups } & \multirow{2}{*}{$\begin{array}{c}\text { Whole } \\
\text { sampling }\end{array}$} \\
\cline { 2 - 5 } & $30-40$ & $40-50$ & sampler \\
\hline $\begin{array}{l}\text { Absence of } \\
\text { nicotine de- } \\
\text { pendence }\end{array}$ & 50 & 50 & 28.6 & 43.5 \\
\hline $\begin{array}{l}\text { Weak nicotine } \\
\text { dependence }\end{array}$ & 16.7 & - & 42.8 & 13.0 \\
\hline $\begin{array}{l}\text { Average nico- } \\
\text { tine depend- } \\
\text { ence }\end{array}$ & - & 40 & 14.3 & 26.1 \\
\hline $\begin{array}{l}\text { Strong nicotine } \\
\text { dependence }\end{array}$ & 33.3 & 10 & 14.3 & 17.4 \\
\hline
\end{tabular}

It is impossible to overcome smoking behavior without knowing motives and reasons for smoking. We determined smoking behavior types among our smoking respondents and revealed that $20 \%$ respondents smoked only casually, mostly to support social contacts. $80 \%$ smokers took average or great number of cigarettes (from 5 to 20) a day and it could mean they had "behavioral" addiction.

Our determination of motives for smoking among our respondents revealed that, as we can see from the Figure, in general "Anxiety support" as a motive for smoking prevailed among the examined sampling; in other words women smoked as they tried to get some support in a complicated psychoemotional situation and to reduce emotional strain and stress. Average value for "Anxiety support" motive amounted to 10.83 and it indicated the motivation here was high.

The second rank place belonged to a group of motives called "Absolute need" (craving for a cigarette), the group value in scores was average that meant average motivation among respondents. This motive can be caused by physical addiction to tobacco. As a result, when nicotine concentration in blood goes down, a person lights a cigarette and smokes in any situation, regardless of possible prohibitions to do it.

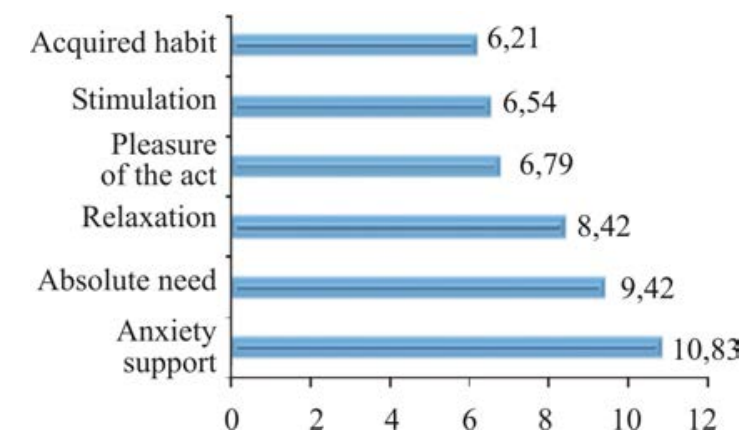

Figure. Hierarchy of respondents' motives for smoking (scores)

Motives from "Relaxation" group took the third rank place; they meant a person wished to get "additional pleasure" when relaxing and thought smoking would help in the matter. This motive was also average among respondents according to its scores.

Such motives as "Pleasure of the act" (a need to manipulate a cigarette), "Stimulation" (wish to feel a stimulating effect and remove fatigue), and "Acquired habit" (a habit, autosmoking when a person smoked when doing his or her work) were less significant as their score values were lower than 7 (weak motivation).

Such motives as "Anxiety support" and "Relaxation" can be so strongly apparent due to influence exerted by certain occupational factors related to work in retail trade. Thus, intensity of consumer flows varies over a day and goods are also delivered unevenly, so workers have to undergo greater loads at "rush hours"; but then there is a break with no consumers or deliveries and they are idle for a period of time. Besides, workers employed at retail outlets have to work under extremely high neuro-psychological stress related to a necessity to serve customers who are very different as per their psychology, intelligence, and education.

We assessed a wish to quit smoking in our respondents and revealed that $58.3 \%$ had only a slight wish to do it, and $33.3 \%$ had an average one. Only $8.4 \%$ badly wanted to give up smoking. 
As we all know, efforts taken by the state in order to limit tobacco smoking cannot be efficient without being understood and supported by the population, especially by retail trade workers. Our research revealed that nonsmoking respondents supported anti-tobacco measures more actively than their smoking counterparts and it corresponded to the trends existing in the country [19].

Thus, $81.3 \%$ non-smokers and $70.8 \%$ smokers were in favor of total prohibition of tobacco advertising. Introduction of fines for smoking in public places was the least supported measure among the respondents although it was the most relevant one for passive smoking prevention. But still, 38\% nonsmoking women and $50 \%$ smoking ones were against it. $50 \%$ non-smokers thought sales of cigarettes were to be completely forbidden; $25 \%$ nonsmokers were in favor of strict prohibition to sell cigarettes to people younger than 21 . Only $37.5 \%$ smokers were in favor of complete ban on sales of cigarettes, and $20.8 \%$, partial (forbidden for those younger than 21).

Conclusions. Our research results allow us to conclude that:

$-60 \%$ of female workers employed in retail trade smoked at the moment when our research was performed; it could be estimated as high exposure to risk factors;
- younger age of introduction to smoking (at age of 11-12 over the last years) was confirmed and it is obvious that school girls are to be more actively informed about health risks and negative consequences related to smoking;

- awareness among smoking respondents about tobacco smoking outcomes and negative attitudes towards smoking unfortunately are not protective factors that make them quit; it means more efficient informational and educational prevention technologies are required;

- most smoking women think that smoking supports them in a complicated psychoemotional situation and helps to reduce emotional strain and stress. In relation to that, if we want to help them quit, it is necessary to improve their central nervous system and behavioral regulation with psychological, social, and medical technologies;

- workers employed in retail trade don't support all the anti-tobacco regulatory measures and it can make them violate the legislation in the sphere; so it is necessary to apply stricter requirements to workers and candidates concerning their addiction to psychoactive substances, including tobacco.

Funding. The research was not granted any sponsor support.

Conflict of interests. The authors state there is no any conflict of interests.

\section{References}

1. Tsitskiev E.R., Maiorova E.A. Analiz sostoyaniya i razvitiya trudovykh resursov torgovli [Labor resources in retail trade: analysis of current state and development]. Luchshaya nauchnaya stat'ya 2016: sbornik statei pobeditelei IV mezhdunarodnogo nauchno-prakticheskogo konkursa, Penza, 2016, pp. 203-208 (in Russian).

2. Osnovnye factory riska neinfektsionnykh zabolevanii [Primary risk factors that cause noninfectious diseases]. Tsentr meditsinskoi profilaktiki: ofitsial'nyi sait. Available at: http://www.medprof.ru/vm9182.html (18.06.2018) (in Russian).

3. Sakharova G.M., Antonov N.S. Tabakokurenie i reproduktivnaya funktsiya zhenshchin [Tobacco smoking and women's reproductive function]. Russkii meditsinskii zhurnal, 2013, vol. 21, no. 1, pp. 12-20 (in Russian).

4. Bochkova L.G., Ershova M.V., Popovskii A.I. Tabachnyi sindrom novorozhdennogo [Neonatal tobacco syndrome]. Saratovskii nauchno-meditsinskii zhurnal, 2008, vol. 4, no. 4, pp. 64-67 (in Russian).

5. Lipanova L.L., Nasybullina G.M., Korotkova M.O. Rol' sem'ii obshcheobrazovatel'nykh uchrezhdenii v ukreplenii zdorov'ya i formirovanii obraza zhizni detei i podrostkov [The role of family and educational institution in health promotion and formation of children's lifestyle]. Acta Biomedica Scientifica, 2013, no. 3-1, pp. 85-90 (in Russian).

6. WHO report on the global tobacco epidemic, 2015. Executive Summary. World Health Organization. 2015. Available at: http://www.who.int/tobacco/global_report/2015/summary/ru/ (18.06.2018). 
7. Who global report on trends in prevalence of tobacco smoking 2015.World Health Organization. 2015. Available at: http://apps.who.int/iris/bitstream/10665/156262/1/9789241564922_eng.pdf(18.06.2018).

8. Global Health Observatory data repository. World Health Organization. 2017. Available at: http://apps.who.int/gho/data/node.main.1250?lang=en (18.06.2018).

9. Kuramysova A. Kazakhstantsy stali men'she kurit' [People are now smoking less in Kazakhstan]. Kazakhstanskaya pravda: Respublikanskaya gazeta, 2015. Available at: http://demoscope.ru/weekly/ 2015/0645/gazeta017.php (18.06.2018) (in Russian).

10. V Belorussii muzhchiny stali kurit' men'she, a zhenshchiny - naoborot [In Belarus men now smoke less than they used too, but women, on the contrary, do it more]. Demoskop Weekly, 2015, no. 665-666. Available at: http://demoscope.ru/weekly/2015/0665/panorm01.php (20.06.2018) (in Russian).

11. Vozrastnye koeffitsienty tekushchego tabakokureniya, 2000, 2010 i 2025 gody [Age coefficients in current tobacco smoking, 2000, 2010, and 2025]. Demoskop Weekly, 2015, pp. 647-648. Available at: http://demoscope.ru/weekly/2015/0647/biblio03.php (20.06.2018) (in Russian).

12. Rusinova N.L., Ozerova O.V., Safronov V.V. Kurenie v Rossii: sotsial'nye razlichiya i tendentsii v 1990-e i 2000-e gg. [Smoking in Russia. Social differences and trends in 1990th to 2000th]. Sotsiologicheskie issledovaniya, 2013, no. 3, pp. 104-113 (in Russian).

13. Gnatyuk O.P., Dobrykh V.A., Yakovlev V.B. Vozrastnye, gendernye i sotsial'nye osobennosti tabakokureniya u zhitelei Priamur'ya [Age, gender and social features of tobacco smoke at inhabitants of the far east of Russia]. Byulleten' fiziologii i patologii dykhaniya, 2008, no. 29, 60 p. (in Russian).

14. Khriptovich V.A. Oprosnik otnosheniya podrostkov k tabakokureniyu [A questionnaire applied to determine teenagers; attitudes towards smoking]. Minsk, RIVSh Publ., 2008, 44 p. (in Russian).

15. Test Fagerstrema na opredelenie nikotinovoi zavisimosti [Fagerstrom test for nicotine dependence]. Gurutestov.ru. Available at: http://www.gurutestov.ru/test/420/ (20.06.2018) (in Russian).

16. Otsenka motivatsii k kureniyu (anketa D. Khorna) i otsenka stepeni motivatsii brosit' kurit'. Lektsii.Org. Available at: https://lektsii.org/7-72448.html (20.06.2018) (in Russian).

17. Pugachev I.Yu., Dutov S.Yu., Osmanov E.M. Rasprostranennost' tabakokureniya sredi razlichnykh grupp naseleniya i puti ego profilaktiki [Tobacco smoking occurrence among various groups of population and preventive measures ways]. Vestnik Tambovskogo universiteta. Seriya: Estestvennye $i$ tekhnicheskie nauki, 2012, vol. 17, no. 2, pp. 791-796 (in Russian).

18. Inglik T.N., Chernyavskaya N.M., Aibazova L.B. Izuchenie motivatsii podrostkov k tabakokureniyu [Studying of motivation of teenagers to tobacco smoking]. Sovremennye problemy nauki i obrazovaniya, 2012, no. 6, 273 p. (in Russian).

19. Zapret na kurenie [Prohibition to smoke]. Levanda-Tsentr: analiticheskii tsentr Yuriya Levandy. 2014. Available at: https://www.levada.ru/2014/07/09/zapret-na-kurenie/ (20.06.2018) (in Russian).

Inglik T.N., Chernyavskaya N.M., Aybazova L.B. Epidemiologic aspects related to tobacco smoking as risk factors for female workers employed in retail trade. Health Risk Analysis, 2019, no. 1, pp. 109-117. DOI: 10.21668/health.risk/2019.1.12.eng

Received: 20.09 .2018

Accepted: 29.01 .2019

Published: 30.03.2019 


\title{
HEALTH RISK ANALYSIS RELATED TO ORGANIZATIONAL TASKS IN PUBLIC HEALTHCARE
}

UDC 613.955: 572.51

DOI: $10.21668 /$ health.risk/2019.1.13.eng

Read

online

\section{HEMODYNAMICS PARAMETERS AS RISK MARKERS OF POTENTIAL DISEASES IN THE CARDIOUVASCULAR SYSTEM AND THEIR ASSESSMENT IN YOUNG MEN WITH DIFFERENT TYPES OF BLOOD CIRCULATION SELF-REGULATION}

\author{
L.I. Grechkina \\ "Arctica" Scientific and Research Center, the Far Eastern Branch of the Russian Academy of Sciences, 24 Karla \\ Marksa av., Magadan, 685000, Russian Federation
}

Functional state of the cardiovascular system is a basic criterion applied for assessing health and adaptive reactions of a human body; therefore, it seemed to be advisable to examine compensatory mechanisms of a human body under exposure to adverse external factors. Our research goal was to study functional parameters of cardiohemodynamics in young men depending on a type of blood circulation self-regulation. We examined 368 young male students born in the northern-eastern regions of Russia. Their average age was equal to $18.5 \pm 0.08$. We measured basic anthropometric parameters of each young student, namely body height and body mass. Cardiohemodynamics parameters were determined in young male students at rest, in a sitting position, via volumetric compression oscillometry with a set of hardware and software complex for non-invasive research of the central hemodynamics ("Globus", Belgorod). Results. We analyzed distribution of individual TBS (type of blood circulation self-regulation) index values and revealed that $48.1 \%$ young men had cardiac TBS; $35.9 \%$, cardiovascular TBS; and 16,0\%, vascular TBS. Young people with the vascular TBS tended to have the highest systolic and diastolic blood pressure, stroke volume, the most powerful left ventricular contraction and overall peripheral vessels contraction; on the contrary, young men with the cardiac TBS tended to have the lowest values of these parameters. Young men with the cardiovascular TBS were somewhere in between the two previously mentioned groups. But at the same time, such parameters as heart rate (HR), pulse wave velocity (PWV), and Kerdo vegetative index (KVI) were the highest in young men with the cardiac TBS; and the lowest ones, in young men with the vascular TBS. This research allows to assess risks of diseases in the cardiovascular system and diabetes in young men so that relevant preventive activities can be performed.

Key words: young men; functional parameters of cardiohemodynamics; types of blood circulation self-regulation; northern-eastern regions of Russia.

Functional state of the cardiovascular system is a basic criterion used to assess health and adaptive responses of a human body.

Adverse external influences cause compensatory insufficiency in a body which can lead to adaptation failure and pathological changes. Given that, it seems quite necessary to develop new methodical approaches to assessing adaptation capabilities of a human body and it is a vital task for preventive medicine since such approaches can allow to determine prenosological changes in functional systems and to work out targeted preventive activities [1-3].
Some experts state that a set of naturalclimatic, ecological, and social-hygienic environmental factors exerts great influence on physical development, formation of functional systems in a human body, and population health $[4,5]$. Since arctic and subarctic areas are being developed and development programs for these territories are being enlarged, it becomes more and more important to examine adaptation and health preservation under extreme climatic conditions existing in the northern regions; research that has been previously performed in the sphere confirms that

(c) Grechkina L.I., 2019

Lyudmila I. Grechkina - Candidate of Biological Sciences, Associate Professor, leading researcher (e-mail: ludmila-50@, mail.ru; tel.: +7 (413) 262-90-72; ORCID: https://0000-0002-9293-9722). 
such conditions exert negative impacts on human health [6-10]. N.I. Arinichin et al. performed an integral assessment of the cardiovascular system functions and analyzed a ratio of the cardiac and vascular components in the central hemodynamics; basing on the results of their assessment and analysis, they detected that there were three basic (standard) types of blood circulation self-regulation in adult people, namely, cardiac, vascular, and cardiovascular one $[11,12]$. A type of blood circulation self-regulation (TBS) is an informative prenosological integral parameter that reflects peculiarities of adaptive responses and phenotypic body properties among healthy people. TBS determination makes it possible to assess strain in the cardiovascular system regulation at various stages in ontogenesis. It was shown that if the vascular component prevailed in blood circulation self-regulation, it meant the process was economized and functional reserves of the cardiovascular system grew to provide long-term adaptation; but if the cardiac component prevailed, it meant that the cardiovascular system functioning was strained and it was necessary to provide adaptation to sudden short-term exposure to perturbing environmental factors. But if TBS is cardiovascular, it means that blood circulation self-regulation is balanced in the most optimal way.

At present a stable population consisting of alien Eastern Slavs is being formed in the northeast Russia. Most young people who live in the region belong to the 1st-3rd generation of Caucasians. The cardiovascular system is one of the most significant body systems that can show whether a body has truly adapted to extreme conditions in the North; health of people who permanently live and work here directly depends on the cardiovascular system functioning.

Our research goal was to examine functional parameters of cardiohemodynamics depending on a type of blood circulation self-regulation in young males born in the northeast Russia.

Research object and methods. We examined cardiohemodynamics in practically healthy young males who studied at a higher educational establishment, were born in Magadan and Magadan region, and belonged to the 1st-2nd generation of Caucasians. The examina- tion was performed before lunchtime in a room with a comfortable temperature. Overall, we examined 368 young males, their average age being $18.5 \pm 0.08$. We measured basic anthropometric parameters of each young male student (body height - $\mathrm{BH}, \mathrm{cm}$, and body weight - BW, kg) with conventional techniques. Cardiohemodynamics parameters were determined in young males at rest, in a sitting position, via volumetric compression oscillometry with a set of hardware and software complex for non-invasive research of the central hemodynamics ("Globus", Belgorod). We registered the following direct and calculated parameters of the central and peripheral hemodynamics: systolic (SBP) and diastolic (DBP) blood pressure $(\mathrm{mmHg})$, heart rate (HR, strokes/min), cardiac output $(\mathrm{CO}, 1 / \mathrm{min})$, stroke volume $(\mathrm{SV}, \mathrm{ml})$, power of the left ventricular contraction (PLVC, Wt), energy consumption required to transfer 1 liter of $\mathrm{CO}$ per minute $(\mathrm{EC}$, $\mathrm{Wt}$ ), overall (OPVR, dyn. ${ }^{*} \mathrm{~s}^{*} \mathrm{~cm}^{-5}$ ) and specific (SPVR, arbitrary units) peripheral vascular resistance, pulse wave velocity (PWV, cm/s), vascular compliance ( $\mathrm{VC}, \mathrm{ml} / \mathrm{mmHg}$ ), type of blood circulation self-regulation (TBS, arbitrary units). TBS index which varies from 90 to 110 means a person has cardiovascular TBS; if TBS index is more than 110, a person has vascular TBS, and if it is less than 90, a person has cardiac TBS. Basing on all the obtained data, we calculated Kerdo vegetative index (KVI, arbitrary units) as per the following formula: KVI $=(1-\mathrm{DBP} / \mathrm{HR})^{*} 100$.

We accomplished our research in full conformity with the principles stated in Helsinki Declaration (2008). The research protocol was approved by the Ethics Committee for medical and biological research at the Northeastern Scientific Center of the RAS Far Eastern Brunch. All the examined young males were provided with complete information on the essence and goals of the research and gave their written consent to take part in it.

The obtained data were statistically processed with such conventional software as Microsoft Excel and StatSoft Statistica 6.0 applied statistical software package. We applied Shapiro-Wilk test W to check whether the obtained data were compliant with the normal distribution law, calculated average values (M), their standard errors $( \pm \mathrm{m})$, and standard devia- 
tions $( \pm \sigma)$. Statistical significance of discrepancies was estimated with Student's t-test for independent samplings provided that distribution was normal. Discrepancies at $\mathrm{p} \leq 0,05$ were considered to be statistically significant.

Results and discussion. Our research revealed that average TBS index value was equal to $92.4 \pm 0.9$ if taken for the overall group on average and it meant that young males tended to have cardiovascular TBS. However, after we analyzed distribution of individual TBS index values, we revealed that $48.1 \%$ among examined young males had cardiac TBS (78.4 \pm 0.6 arbitrary units); 35.9\%, cardiovascular TBS (98.8 \pm 0.5 arbitrary units); and $16.0 \%$, vascular TBS $(120.1 \pm 1.1$ arbitrary units). Young males with different TBS didn't have any discrepancies in average values of their body height and body weight. In order to detect peculiarities in the cardiovascular system functioning in young males with different TBS, we analyzed distribution of individual hemodynamics parameters as per TBS index (Table).

Table

Anthropometric and hemodynamic parameters in young male students with different types of blood circulation self-regulation living in Magadan $(M \pm \sigma)$

\begin{tabular}{|c|c|c|c|c|}
\hline \multirow{3}{*}{ Parameters } & \multicolumn{3}{|c|}{ Type of blood circulation self-regulation } & \multirow{3}{*}{$\mathrm{P}$} \\
\hline & $\begin{array}{l}\text { Cardiac } \\
\text { (1) }\end{array}$ & Cardiovascular (2) & $\begin{array}{l}\text { Vascular } \\
\text { (3) }\end{array}$ & \\
\hline & $\mathrm{n}=177$ & $\mathrm{n}=132$ & $\mathrm{n}=59$ & \\
\hline $\mathrm{BH}, \mathrm{cm}$ & $179.3 \pm 7.4$ & $179.8 \pm 7.8$ & $178.7 \pm 6.7$ & \\
\hline $\mathrm{BW}, \mathrm{kg}$ & $69.9 \pm 11.9$ & $72.8 \pm 12.5$ & $73.1 \pm 11.9$ & \\
\hline $\mathrm{SBP}, \mathrm{mmHg}$ & $125.8 \pm 12.7$ & $128.3 \pm 11.5$ & $132.1 \pm 14$ & $\mathrm{P}<0.011^{1-3}$ \\
\hline DBP, mmHg & $61.8 \pm 7.7$ & $67.0 \pm 8.1$ & $73.2 \pm 11.5$ & $\begin{array}{l}\mathrm{P}<0.001^{1-2} \\
\mathrm{P}<0.001^{2-3} \\
\mathrm{P}<0.001^{1-3}\end{array}$ \\
\hline BP pulse, $\mathrm{mmHg}$ & $63.9 \pm 14.5$ & $61.3 \pm 13.1$ & $58.9 \pm 14.1$ & $\mathrm{P}<0.05^{1-3}$ \\
\hline HR, strokes/min & $79.7 \pm 12.1$ & $68.1 \pm 8.9$ & $61.2 \pm 10.4$ & $\begin{array}{l}\mathrm{P}<0.001^{1-2} \\
\mathrm{P}<0.001^{2-3} \\
\mathrm{P}<0.001^{1-3}\end{array}$ \\
\hline $\mathrm{CO}, 1 / \mathrm{min}$ & $6.21 \pm 0.89$ & $6.21 \pm 0.79$ & $6.19 \pm 0.75$ & \\
\hline $\mathrm{SV}, \mathrm{ml}$ & $79.6 \pm 16.4$ & $92.8 \pm 17.0$ & $103.9 \pm 22.5$ & $\begin{array}{l}\mathrm{P}<0.001^{1-2} \\
\mathrm{P}<0.001^{2-3} \\
\mathrm{P}<0.001^{1-3}\end{array}$ \\
\hline PLVC, Wt & $2.96 \pm 0.68$ & $3.44 \pm 0.64$ & $4.01 \pm 0.90$ & $\begin{array}{l}\mathrm{P}<0.001^{1-2} \\
\mathrm{P}<0.001^{2-3} \\
\mathrm{P}<0.001^{1-3}\end{array}$ \\
\hline $\mathrm{PWV}, \mathrm{cm} / \mathrm{sec}$ & $999.4 \pm 124.9$ & $975.5 \pm 96.4$ & $940.3 \pm 101.7$ & $\begin{array}{l}\mathrm{P}<0.001^{2-3} \\
\mathrm{P}<0.001^{1-3}\end{array}$ \\
\hline $\mathrm{VC}, \mathrm{ml} / \mathrm{mmHg}$ & $1.32 \pm 0.19$ & $1.61 \pm 0.19$ & $1.86 \pm 0.25$ & $\begin{array}{l}\mathrm{P}<0.001^{1-2} \\
\mathrm{P}<0.001^{2-3} \\
\mathrm{P}<0.001^{1-3}\end{array}$ \\
\hline $\begin{array}{l}\text { OPVR, } \\
\text { dyn.*sec* } \mathrm{cm}^{-5}\end{array}$ & $1042 \pm 135$ & $1073 \pm 111$ & $1128 \pm 146$ & $\begin{array}{l}\mathrm{P}<0.05^{1-2} \\
\mathrm{P}<0.05^{2-3} \\
\mathrm{P}<0.001^{1-3}\end{array}$ \\
\hline SPVR, arbitrary units & $24.1 \pm 2.4$ & $25.2 \pm 2.5$ & $26.6 \pm 3.5$ & $\begin{array}{c}\mathrm{P}<0.001^{1-2} \\
\mathrm{P}<0.01^{2-3} \\
\mathrm{P}<0.001^{1-3}\end{array}$ \\
\hline
\end{tabular}

Note: validity of discrepancies is calculated as per $\mathrm{M} \pm \mathrm{m}$ 


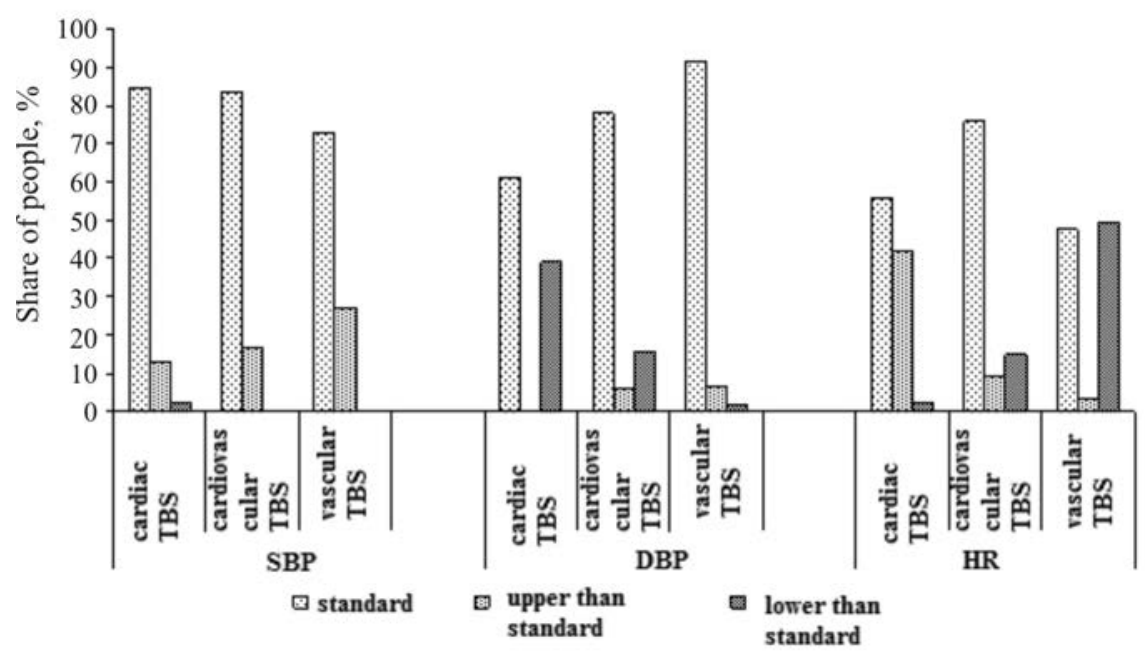

Figure. Distribution of young males as per individual values of SBP, DBP, and HR within groups with different types of blood circulation self-regulation (\%)

The analysis revealed that there were significant discrepancies in values of the examined hemodynamic parameters in young males with different types of blood circulation selfregulation. We detected that people with vascular TBS tended to have the highest values of such functional parameters of the cardiovascular system as SBP, DBP, SV, PLVC, OPVR, SPVR, and VC; people with cardiac TBS tended to have the lowest values of the same parameters; and young males with cardiovascular TBS were somewhere in between as per values of these parameters. At the same time, such parameters as BP pulse, HR, PWV, and KVI were the highest in young males with cardiac TBS; the lowest, in those with vascular TBS. We didn't reveal any authentic discrepancies in $\mathrm{CO}$ between young males with different TBS; it means that blood circulation in all young males, regardless of their TBS, is at its optimal level when a body is at rest and all the physiological needs are quite satisfied.

Systolic and diastolic blood pressure and heart rate are the most available for detection and informative functional hemodynamics parameters. We detected that average values of these parameters, both among the overall sampling and in groups with different TBS, corresponded to age-related standards in spite of all statistically significant discrepancies between groups; thus, average SBP was 100-139 $\mathrm{mmHg}$; average DBP, $60-89 \mathrm{mmHg}$; and HR,
60-80 strokes per minute. However, averaged values don't allow to estimate variability of individual parameters within groups. To assess it, we analyzed individual values of the examined parameters in groups with different TBS (Figure).

The performed analysis allowed to reveal that individual SBP, DBP, and HR were significantly labile in each group of young males. Thus, distribution as per SBP showed that the highest shares of people who had this parameter within "standard" were in groups with cardiac TBS (84.7\%) and cardiovascular TBS $(83.3 \%)$; the lowest share was in the group with vascular TBS (72.9\%). An insignificant share of people with low SBP was found only among young males with cardiac TBS $(2.3 \%)$; the highest share of people with the parameters exceeding the standards was detected among young males with vascular TBS $(27.1 \%)$. As regards DBP, we detected an inverse correlation here: the share of people with DBP within "standards" prevailed significantly among young males with vascular TBS (91.5\%) against those with cardiac TBS (61.0\%). DBP that was lower than "standards" was more frequently detected among young people with cardiac TBS $(39.0 \%)$ than among those with cardiovascular TBS (15.9\%) and vascular TBS $(1.7 \%)$; DBP that was higher than "standard" was detected only in the group with vascular TBS $(6.8 \%)$. Young males with cardiovascular 
TBS were somewhere in between as regards distribution as per DBP value. Distribution as per HR values revealed that the highest share of people with this parameter being within "standards" was among young males with cardiovascular TBS (75.8\%), while a significant number of people with cardiac TBS had this parameter higher than "standards" ("tachycardia", 41.8\%), and about a half young males with vascular TBS (49.1\%) had this parameter lower than "standards", or, in other words, they had "bradycardia".

Pulse blood pressure (BP pulse) is known to depend not only on the heart contractility but also on vascular compliance of large arteries. The more blood is pumped into the bloodstream and the more rigid an arterial wall is, the higher is pulse blood pressure. Our research results revealed a trend for lower BP pulse values from cardiac TBS to vascular one $(63.9 \pm 1.1 \rightarrow 58.9 \pm 1.8 \mathrm{mmHg})$ and statistically significant discrepancies between the two end types of blood circulation self-regulation $(\mathrm{P}<0.05)$.

Stroke volume (SV) and power of the left ventricle contraction (PLVC) are important parameters that characterize the heart functioning. The comparative analysis revealed that young males with vascular TBS tended to have the highest values of these parameters, and young males with cardiac TBS tended to have the lowest ones. Distribution as per PLVC values showed that $22.0 \%$ young males with vascular TBS and $6.1 \%$ young males with cardiovascular TBS had this parameters higher than the standard. 9\% young males with cardiac TBS had insufficient PLVC, and we didn't detect anything similar in two other groups. All the rest young males had PLVC values within age-related standards $(2.0-4.5 \mathrm{Wt})$.

We revealed statistically significant discrepancies between groups with different TBS as per pulse wave velocity (PWV) and vascular compliance (VC) that characterize vessels elasticity and conveying capacity of the artery bloodstream as a whole. The highest PWV values were detected among young males with cardiac TBS $(999.4 \pm 9.4 \mathrm{~cm} / \mathrm{sec})$; the lowest ones, among those with vascular TBS (940.3 \pm $\pm 13.2 \mathrm{~cm} / \mathrm{sec})$. Young males with cardiovascular TBS were somewhere in between as per this parameter. We saw an inverse picture as per VC values as the highest ones were detected among young males with vascular TBS, and the lowest ones were detected among those with cardiac TBS. We should note that, despite any discrepancies, average PWV and VC values were within the standards in each group of young males $(600-1000 \mathrm{~cm} / \mathrm{sec}$ and $1.03-2.35 \mathrm{mmHg}$ ). However, distribution of males as per individual PWV values revealed that a certain number of people within each group had PWV higher than the upper boundary of the standard. Thus. the highest share of people with PWV exceeding the standard was detected among young males with cardiac TBS $(53.7 \%)$, and the lowest one, among those with vascular TBS (28.8\%); there were $38.6 \%$ young males with their PWV higher than the standards in the group with cardiovascular TBS. All the rest young males in all three groups had their PWV within the standards. As regards $\mathrm{VC}, 92.66 \%$ young males with cardiac TBS and $96.6 \%$ young males with cardiovascular TBS had this parameter within the standards. VC values that were lower than the standard were detected only among young males with cardiac TBS (7.34\%); and VC values that were higher than the standard were detected only among those with vascular TBS $(3.4 \%)$. All the young males with cardiovascular TBS had this parameter within the standards.

N.V. Gorymanova et al (2015) and v.V. Skibitsky et al (2018) detected a correlation between PWV and vessels elasticity, blood pressure, and carbohydrate metabolism [13, 14]. It was shown that the greater pulse wave velocity was, the more rigid were the arteries, and the higher were concentrations of dextrose and glycated hemoglobin in blood. In these authors' opinion, elevated PWV is associated with carbohydrate metabolism disorders in relation to tissues being less sensitive to effects produced by insulin [13]. I.V. Averyanova and A.L. Maximov showed that $25-28 \%$ out of young male students examined by them in Magadan had dextrose concentration in their blood at the upper boundary of the standard or 
even exceeding it, and it allowed the authors to conclude that these young males were in prediabetic state and to assign them into a group of people who ran a risk of possible persistent disorders in carbohydrate metabolism [15].

We compared the data which we obtained for PWV values with the results obtained by the above-mentioned authors and it allowed us to make a tentative conclusion that young males with $\mathrm{PWV}>1000 \mathrm{~cm} / \mathrm{sec}$, who were present in each TBS group had carbohydrate metabolism disorders and were prone to accelerated biological ageing of the vessels. We also detected statistically significant discrepancies as per OPVR and SPVR parameters between the groups with different TBS. The highest OPVR and SPVR values were detected among young males with vascular TBS $\left(1,128 \pm 19\right.$ dyn. ${ }^{*} \mathrm{~s}^{*} \mathrm{~cm}^{-5}$ and $26.6 \pm 0.5$ arbitrary units); and the lowest ones, among young males with cardiac TBS $\left(1,042 \pm 10\right.$ dyn. ${ }^{*} \mathrm{~s}^{*} \mathrm{~cm}^{-5}$ and $24.1 \pm 0.2$ arbitrary units).

Conclusion. Practically healthy young males who lived in Magadan could have any of the three types of blood circulation selfregulation, namely cardiac, vascular, or cardiovascular one, depending on a ratio of the cardiac and vascular components. We detected that blood pressure and cardiac output that were integral parameters of tissue circulation efficiency were maintained with different regulatory mechanisms in young males from Magadan with the end hemodynamics regulation types when their bodies were at rest. If a young male had cardiac TBS, these parameters were regulated due to higher heart rate and prevailing sympathetic influence on the heart functioning ( $\mathrm{KVI}=21.6 \pm 0.6$ ); if a young male had vascular TBS, they were maintained due to greater contractility of the cardiac muscle, greater stroke volume, and overall peripheral vessels resistance with prevailing parasympathetic regulation $(\mathrm{KVI}=-20.1 \pm 1.1)$. Young males with cardiovascular TBS had the most well-balanced blood circulation self-regulation $(\mathrm{KVI}=1.2 \pm 0.5)$. Intragroup dynamics of SBP, DBP and HR values distribution allowed us to conclude that central hemodynamics regulation mechanisms related to the cardiac component prevailed among young males who were born in Magadan. There was a certain number of people with elevated SBP $(13 \%$ in cardiac TBS group; $16.7 \%$, in cardiovascular TBS group; and $27.1 \%$, in vascular TBS group) and DBP values were rather labile; it proves there is a risk of arterial hypertension, especially among young males with vascular TBS. Our research revealed that there were young males with SBP values higher than the standards in each group. Basing on the literature sources $[13,14,15]$ and the data which we obtained in our research we can make a tentative conclusion that SBP values which are considerably higher than the upper boundary of the standard, which is especially characteristic for young males with cardiac TBS, can be adverse predictors of risks related to persistent disorders in carbohydrate metabolism and diabetes, susceptibility to thrombus occurrence, greater "rigidity" of the arteries and cardiac and cerebrovascular complications.

Funding. The research was not granted any sponsor support.

Conflict of interests. The authors state there is no any conflict of interests.

\section{References}

1. Rakhmanin Yu.A., Mikhailova R.I. Okruzhayushchaya sreda i zdorov'e: prioritety profilakticheskoi meditsiny [Environment and health: priorities of preventive medicine]. Gigiena i sanitariya, 2014, vol. 93, no. 5, pp. 5-10 (in Russian).

2. Oganov R.G. Profilakticheskaya kardiologiya: nadezhdy i real'nost' [Preventive cardiology: expectations and reality]. Zdravookhranenie, 2012, no. 9, pp. 60-7 (in Russian).

3. Baevskiy R.M., Berseneva A.P., Bersenev E.Yu., Eshmanova A.K. Ispol'zovanie printsipov donozologicheskoi diagnostiki dlya otsenki funktsional'nogo sostoyaniya organizma pri stressornykh vozdeistviyakh [Using the principles of prenosological diagnostics to assess the functional state of the organism under stress conditions]. Human Physiology, 2009, vol. 35, no. 1, pp. 41-51 (in Russian). 
4. Agadzhanyan N.A., Khomchenko O.A., Makarova I.I. Osobennosti deyatel'nosti serdechno-sosudistoi sistemy i psikhoemotsional'noi sfery yunoshei-podrostkov urbanizirovannoi i rekreatsionnoi zon Tverskogo regiona [Peculiarities of cardiovascular system activity and psycho-emotional spfhere of boys-adolescents in urbanized and recreation zones of the Tver region]. Ecologiya cheloveka, 2003, no. 6, pp. 6-8 (in Russian).

5. Minasyan S.M., Gevorkyan E.S., Adamyan Ts.I., Ksadjikyan N.N. Izmenenie kardiogemodinamicheskikh pokazatelei i ritma serdtsa studentov pod vozdeistviem uchebnoi nagruzki [Change of cardiodynamic parameters and the heart rhythm in students under influence of the academic load]. Russian Journal of Physiology, 2006, vol. 92, no. 7, pp. 817-826 (in Russian).

6. Boyko E.R. Problemy adaptatsii cheloveka k ekologicheskim i sotsial'nym usloviyam Severa [Problems of Human Adaptation to the Ecological and Social Conditions of the North]. In: Boyko E.R. ed. St. Petersburg Publ., 2009, 268 p. (in Russian).

7. Soroko S.I., Aldasheva A.A. Individual'nye strategii adaptatsii cheloveka v ekstremal'nykh usloviyakh [Individual Strategies of Human Adaptation Under Extreme Conditions]. Human Physiology, 2012, vol. 38, no. 6, pp. 38-86 (in Russian).

8. Gudkov A.B., Popova O.N., Lukmanova N.B. Ekologo-fiziologicheskaya kharakteristika klimaticheskikh faktorov Severa. Obzor literatury [Ecological-physiological characteristic of Nothern climatic faktors. Literature review]. Ecologiya cheloveka, 2012, no. 1, pp. 12-17 (in Russian).

9. Khasnulin V.I. Zdorov'e cheloveka i kosmogeofizicheskie faktory Severa [Human health and space geophysical factors of the North]. Ecologiya cheloveka, 2013, no. 12, pp. 3-13 (in Russian).

10. Nikitin Yu.P., Khasnulin V.I., Gudkov A.B. Sovremennye problemy severnoi meditsiny i usiliya uchenykh po ikh resheniyu [Contemporary Problems of Northern Medicine and Researchers' Efforts to Solve Them]. Vestnik Severnogo (Arkticheskogo) federal'nogo universiteta. Ser. Mediko-biologicheskie nauki, 2014, no. 3, pp. 63-72 (in Russian).

11. Arinchin N.I. Problema tenzii i tonii v norme i patologii krovoobrashcheniya [Problems of tension and tonia of blood circulation under normal and pathological conditions]. Human Physiology, 1978, vol. 4, no 3, pp. 426-35 (in Russian).

12. Arinchin N.I., Gorbacevich A.I., Kononcev V.I. Ekspress-metod opredeleniya tipov samoregulyatsii krovoobrashcheniya, predpatologicheskikh sostoyanii i patogeneticheskikh form giper- i gipotenzii [Short-term test for determining of blood circulation types, pre-pathological states and pathogenic forms of hyper- and hypotension]. Automatization of scientific studies: Proceedings of XI of All-Soviet Union School on automatization of scientific studies, Minsk, 1978, pp. 31-34 (in Russian).

13. Gomyranova N.V., Metelskaya V.A., Tkacheva O.N. [et al.]. Issledovanie vzaimosvyazi pokazatelei zhestkosti arterii s biokhimicheskimi faktorami aterotromboza u lits raznogo vozrasta [Assessment of the relation between arterial stiffness parameters and atherothrombosis factors in various age groups]. Cardiovascular Therapy and Prevention, 2015, vol. 14, no. 3, pp. 65-69 (in Russian). DOI: 10.15829/1728-8800-2015-3-65-69

14. Skibitsky V.V., Gutova S.R., Fendrikova A.V. Osobennosti sutochnogo profilya arterial'nogo davleniya, sosudistoi zhestkosti i tsentral'nogo aortal'nogo davleniya u bol'nykh arterial'noi gipertoniei s rannimi narusheniyami uglevodnogo obmena [Features of diurnal blood pressure profile, arterial stiffness and central aortic pressure in patients with arterial hypertension and prediabetes]. Kuban Scientific Medical Bulletin, 2018, vol. 25, no. 2, pp. 127-134 (In Russian). DOI: 10.25207/1608-6228-2018-25-2-127-34

15. Averyanova I.V., Maximov A.L. Osnovnye kharakteristiki lipidnogo i uglevodnogo obmena u yunoshei Severo-Vostoka Rossii s razlichnymi tipami teloslozheniya [Main characteristics of lipid and carbohydrate metabolism observed in young males with different somatotypes of northeast Russia]. Ecologiya cheloveka, 2017, no 12, pp. 40-44 (in Russian).

Grechkina L.I. Hemodynamics parameters as risk markers of potential diseases in the cardiouvascular system and their assessment in young men with different types of blood circulation self-regulation. Health Risk Analysis, 2019, no. 1, pp. 118-124. DOI: 10.21668/health.risk/2019.1.13.eng

Received: 01.10 .2018

Accepted: 26.01.2019

Published: 30.03.2019 
UDC 613.8: 614.1

DOI: 10.21668/health.risk/2019.1.14.eng

\title{
RISK FACTORS THAT CAUSE DEVELOPMENT AND PROGRESSION OF DEGENERATIVE AND DYSTROPHIC DISEASES IN THE SPINAL COLUMN AS PER RESULTS OBTAINED DURING SCREENING TESTS ON PEOPLE LIVING IN SAINT PETERSBURG
}

\author{
M.V. Avdeeva ${ }^{1}$, Yu.A. Kreneva ${ }^{2}$, V.P. Panov ${ }^{1,2}$, V.N. Filatov ${ }^{1}$, \\ A.V. Mel'tser ${ }^{1}$, L.A. Karasaeva ${ }^{1}$
}

${ }^{1}$ I.I. Mechnikov's North-Western State Medical University of the RF Public Healthcare Ministry, 47 Piskarevskiy av., Saint Petersburg, 195067, Russian Federation

${ }^{2}$ Municipal polyclinic No.14, 35 the 2nd Murinskiy av, Saint Petersburg, 194021, Russian Federation.

According to the WHO, degenerative-dystrophic diseases in the spinal column occur in $80 \%$ of overall population and account for up to $90 \%$ of all the chronic diseases cases. Data and methods. To assess prevalence of degenerative-dystrophic diseases in the spinal column among people living in Saint Petersburg, we performed screening tests on 5,797 people (their average age was $56.52 \pm 18.39$; body mass index was $26.78 \pm 15.42 \mathrm{~kg} / \mathrm{m}^{2}$; spine length was $443.30 \pm 39.85 \mathrm{~mm})$. Men accounted for $25.6 \%$ among the examined people $(n=1,482)$; women, for $74.4 \%(n=4,315)$. All the participants underwent a complex examination; they were questioned (we applied a specially designed questionnaire made up of 124 questions); their spinal columns (3 sections in them) were x-rayed; we also accomplished computer optical topography with "DIERS Formetric 4D" device (Germany); the last stage was a consultation by a neurologist.

The prevalence of degenerative-dystrophic diseases in the spinal column amounts to $71.5 \%$ among people living in Saint Petersburg. We detected functional disorders in the spinal column in all the examined patients. Degenerativedystrophic diseases in the spinal column can progress not only due to functional disorders in it but also under influence exerted by social and economic factors such as social status $(b=0.43 ; p<0.01)$, age $(b=0.18 ; p<0.01)$, occupational peculiarities $(b=0.17 ; p<0.01)$, limited financial opportunities to preserve health $(b=0,15 ; p<0,01)$. Personal and behavioral factors also exert their impacts on risks of degenerative-dystrophic diseases; such factors are rare appeal for medical aid $(b=0.18$; $p<0.01)$, poor literacy of the population $(b=0,17 ; p<0,01)$, self-treatment $(b=0.14 ; p<0.01)$. Poor quality of medical health also causes elevated risks of degenerative-dystrophic diseases $(b=0.18 ; p<0.01)$.

Most risk factors that influence development and progression of degenerative-dystrophic diseases in the spinal column are manageable (behavioral-personal factors, socioeconomic factors, quality and availability of medical aid). Timely examination, treatment, and rehabilitation of patients suffering from degenerative-dystrophic diseases are important spheres where quality and availability of primary medical and sanitary care can be improved.

Key words: prevalence of degenerative-dystrophic diseases in the spinal column, risk factors, osteochondrosis risk, age-related changes in the spinal column.

(c) Avdeeva M.V., Kreneva Yu.A., Panov V.P., Filatov V.N., Mel'tser A.V., Karasaeva L.A., 2019

Marina V. Avdeeva - Doctor of Medicine, Professor at the Department of Public Health, Economics and Health Management (e-mail: Lensk69@mail.ru; tel.: + 7 (812) 543-02-32; ORCID: http://orcid.org/0000-0002-4334-5434).

Julia A. Kreneva - Head of the Rehabilitation Department (e-mail: krenewa@yandex.ru; tel.: 7 (812) 550-24-67; ORCID: https://orcid.org/0000-0002-4926-9639).

Viktor P. Panov - Doctor of Medicine, Professor at the Department of Public Health, Economics and Health Management (e-mail:p1-4@yandex.ru; tel.: 7 (812) 550-24-67; ORCID: https://orcid.org/0000-0002-0894-6656).

Vladimir N. Filatov - Doctor of Medicine, Professor, Head of the Department of Public Health, Economics and Health Management (e-mail: Vladimir.Filatov@szgmu.ru; tel.: +7 (812) 543-02-32; ORCID: http://orcid.org/0000-0003-1017-9975).

Alexander V. Mel'tser - Doctor of Medicine, Professor, Vice-Rector responsible for the development of regional health care and preventive medical care (e-mail: rectorat@szgmu.ru; tel.: + 7 (812) 303-50-00; ORCID: https://orcid.org/ 0000-0003-4186-457X).

Lyudmila A. Karasaeva - Doctor of Medicine, Professor at theDepartment of Public Health, Economics and Health Management (e-mail: ludkaras@yandex.ru; tel.: +7(812) 543-02-32; ORCID: https://orcid.org/0000-0001-5621-0240). 
Introduction. According to the WHO, degenerative and dystrophic spine diseases (DDSD) occur in $80 \%$ population and account for up to $90 \%$ of all the chronic diseases $[1,2,3,4,5]$. Screening x-ray examinations reveal that the first signs of DDSD, namely a decrease in intervertebral spaces, occur as early as at the age of 6 ; and when a person is 12 he or she already has subchondral bone sclerosis [6]. Each fifth person in the world who is older than 30 suffers from DDSD [1, 7]. Pathologies in the musculoskeletal system occupy the first place in the overall morbidity structure among people who are older than $50[8,9]$. Some data imply that DDSD prevalence and disorders in the spinal column functioning amount to 122 per 1,000 adults. And at the same time 80$100 \%$ people occasionally suffer from spondylogenic pains in the spine $[10,11]$, but only about $40 \%$ of them apply for medical aid [12]. DDSD with spondylogenic pain syndrome as a reason to visit a doctor occupies the second place after respiratory diseases and it holds the third place among reasons for admission to hospital [13, 14, 15, 16]. A number of such admissions due to spondylogenic pain syndrome has been growing over the recent years [17]. About $10 \%$ of all the patients suffering from DDSD become disabled, and the figure is substantially higher among patients who have undergone a surgery and it reaches $70.3 \%$ [18]. Therefore, DDSD prevalence can be considered a pandemic and it is a grave medical and socioeconomic problem in the developed countries [2, 19]. But still, timely detection, treatment, and rehabilitation is extremely important for improving life quality and medical and social forecasts for patients suffering from DDSD.

Our research goal was to examine prevalence and risk factors that cause degenerative and dystrophic spine diseases (DDSD) in people living in Saint Petersburg as per results of a complex screening examination.

Data and methods. To assess DDSD prevalence among people living in Saint Pe- tersburg, we performed a screening examination of 5,797 people (their average age was equal to $56.52 \pm 18.39$; body mass index was $26.78 \pm 15.42 \mathrm{~kg} / \mathrm{m}^{2}$; spine length was $443.30 \pm$ $\pm 39.85 \mathrm{~mm}) .25 .6 \%$ of the examined people were males $(n=1,482)$, and $74.4 \%$ females $(n=4,315)$. People were chosen for examination via a simple random sampling among people who lived on a territory where medical services were provided by a municipal polyclinic. There was an age-related criterion for people to be included into the sampling as they had to be 18 years old or older. Anyone who refused to take part in the examination was not included into the sampling.

All the participants underwent a complex examination: they were questioned (we applied a specially designed questionnaire that contained 124 questions); their spinal columns (all three sections) were x-rayed; we performed computer optical topography with "DIERS Formetric 4D" device (Germany) as per a conventional procedure [20,21]; all the people included in the sampling were examined by a neurologist. Computer optical topography allowed to assess biomechanics of the spinal column and pelvis as per the following parameters: spine length in $\mathrm{mm}$ (C7-DMmm), spine curve in degrees $\left(\mathrm{C} 7-\mathrm{DM}^{\circ}\right)$, vertical deviation in $\mathrm{mm}$ (VP-DMmm), pelvis tilt in degrees (DL-DR ${ }^{\circ}$ ), pelvis tilt in $\mathrm{mm}$ (DL-DRmm), pelvis rotation in degrees (DL-DR ${ }^{\circ}$ ), pelvis curve in degrees, kyphosis angle in degrees (ICT-ITL ${ }^{\circ}$ ), lumbar lordosis angle in degrees (ITL-ILS ${ }^{\circ}$ ), rotation of surface in degrees $\left(\mathrm{RMS}^{\circ}\right)$, lateral deviation in $\mathrm{mm}$ (VPDMmm).

All the obtained data were statistically analyzed with "Statistica 10.0" applied software package. Statistical data are given as a simple mean and standard deviation $(\mathrm{M} \pm \sigma)$ or a percent $(\%)$. When qualitative signs were compared, we calculated $\chi^{2}$ criterion. We also performed multiple regression with stepwise elimination and determination of regression quotient $b$. Discrepancies were considered to be statistically significant at $p<0.05$. 
Results. X-ray revealed DDSD signs in $71.5 \%$ of the examined people. $15.4 \%$ of them suffered from pains in the thoracic spine when they were examined; $14.7 \%$, from pains in the cervical spine; and $41.3 \%$, from pains in the lumbar spine (Figure 1).

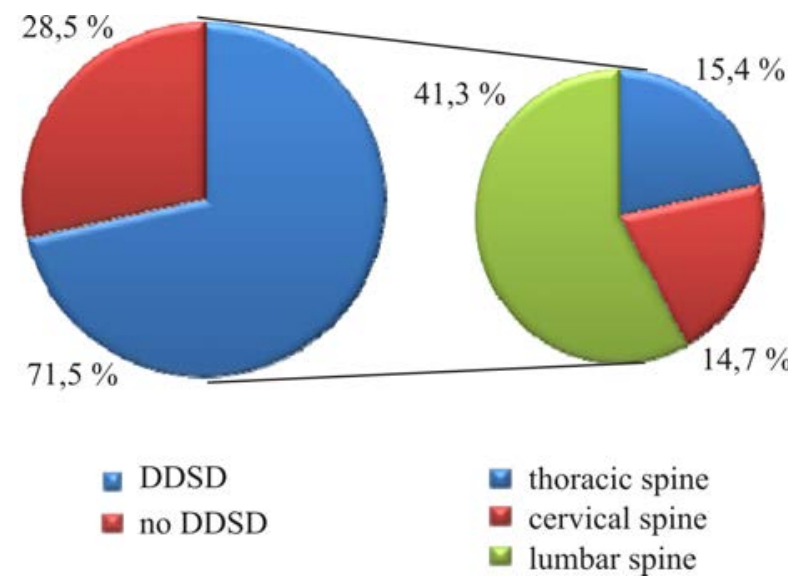

Figure 1. DDSD prevalence among people living in Saint Petersburg as per screening examination data

Computer optical topography revealed that $100 \%$ examined people had functional disorders in the spinal column. As we can see from the data presented in Table 1, such functional disorder as a change in lumbar lordosis angle was the most frequent $(81.2 \%)$, values of the parameter being either higher than the reference one $(50.3 \%)$ or lower than it $(30.9 \%)$. Besides, the examination revealed such functional disorders in the spinal column as deviations from the standard spine curve $(75.0 \%)$ and kyphosis angle $(67.9 \%)$.

Regression analysis revealed that signs of spondylogenic pain syndrome occurred not only under influence exerted by functional state of the spine (spine length, kyphosis angle, spine curve, rotation of surface, lordosis angle, and pelvis curve) but also by biological factors. Thus, data presented in Table 2 indicate that spondylogenic pain syndrome can occur due to constitutive peculiarities of a patient (body mass index $(b=0.09 ; \mathrm{p}<0.05)$ and age $(b=0.04 ; p<0.05)$. In particular, patients who didn't have any pain syndrome turned out to be younger $(51.67 \pm 18.92$ and $55.28 \pm 17.28 ; \mathrm{p}<0.01)$ and had lower body mass index $(25.74 \pm 13.11$ and $26.79 \pm 7.04$; $\mathrm{p}<0.01)$ than those who complained of a chronic pain syndrome.

Regression analysis allowed to spot out basic DDSD-associated factors. They are all stratified into three categories: 1) socioeconomic factors (social status, age, limited financial means to preserve health etc.);

Table 1

Prevalence of functional disorders in the spinal column as per results obtained vi screening computer optical topography

\begin{tabular}{|c|c|c|c|c|c|c|}
\hline \multirow[t]{2}{*}{ Parameters } & \multicolumn{2}{|c|}{$\begin{array}{l}\text { No functional } \\
\text { disorders }\end{array}$} & \multicolumn{2}{|c|}{$\begin{array}{l}\text { Functional disorders } \\
\text { are detected }\end{array}$} & \multirow[t]{2}{*}{$\chi^{2}$} & \multirow[t]{2}{*}{$\mathrm{p}$} \\
\hline & $\%$ & Abs. & $\%$ & Abs. & & \\
\hline Spine curve in degrees $\left(\mathrm{C}^{2}-\mathrm{DM}^{\circ}\right)$ & $25.0 \%$ & 1,449 & 75.0 & 4,348 & 50.0 & $<0.01$ \\
\hline Vertical deviation in mm (VP-DMmm) & $51.4 \%$ & 2,979 & $48.6 \%$ & 2,818 & 0.18 & $>0.05$ \\
\hline Pelvis tilt in degrees $\left(\mathrm{DL}^{-\mathrm{DR}^{\circ}}{ }^{\circ}\right.$ & $95.0 \%$ & 5,509 & $5.0 \%$ & 288 & 162.0 & $<0.01$ \\
\hline Pelvis tilt in mm (DL-DRmm) & $54.3 \%$ & 3,150 & $45.7 \%$ & 2,647 & 1.28 & $>0.05$ \\
\hline Pelvis rotation in degrees $\left(\mathrm{DL}-\mathrm{DR}^{\circ}\right.$ ) & $52.9 \%$ & 3,066 & $47.1 \%$ & 2,731 & 0.72 & $>0.05$ \\
\hline Pelvis curve in degrees & $50.4 \%$ & 2,922 & $49.6 \%$ & 2,875 & 0.02 & $>0.05$ \\
\hline Kyphosis angle in degrees $\left(\right.$ ICT-ITL $^{\circ}$ ) & $32.1 \%$ & 1,861 & $67.9 \%$ & 3,936 & 24.5 & $<0.01$ \\
\hline $\begin{array}{l}\text { Lumbar lordosis angle in degrees } \\
\left(\text { ITL-ILS }{ }^{\circ} \text { ) }\right.\end{array}$ & $18.8 \%$ & 1,087 & $81.2 \%$ & 4,710 & 79.4 & $<0.01$ \\
\hline Rotation of surface in degrees $\left(\mathrm{RMS}^{\circ}\right)$ & $57.9 \%$ & 3,359 & $42.1 \%$ & 5,326 & 4.5 & $<0.05$ \\
\hline Lateral deviation in degrees (VPDMmm) & $85.2 \%$ & 4,937 & $14.8 \%$ & 860 & 100.83 & $<0.01$ \\
\hline
\end{tabular}


Functional changes in the spine that are associated with a risk of DDSD occurrence and development and spondylogenic pain syndrome

(multiple regression with stepwise elimination)

\begin{tabular}{|c|c|c|c|}
\hline $\begin{array}{l}\text { Risk factor associated with pain syndrome } \\
\text { occurrence }\end{array}$ & $\begin{array}{l}\text { Regression } \\
\text { quotient } b\end{array}$ & $\begin{array}{l}\text { Standard } \\
\text { error } \mathrm{m}\end{array}$ & $\mathrm{p}$ \\
\hline Kyphosis angle in degrees (ICT-ITL $^{\circ}$ ) & 0.14 & 0.02 & $<0.001$ \\
\hline Spine curve in degrees $\left(\mathrm{C}^{2}-\mathrm{DM}^{\circ}\right)$ & 0.12 & 0.02 & $<0.01$ \\
\hline Body mass index $\left(\mathrm{kg} / \mathrm{m}^{2}\right)$ & 0.09 & 0.01 & $<0.01$ \\
\hline Spine length in $\mathrm{mm}$ (C7-DMmm) & 0.06 & 0.02 & $<0.01$ \\
\hline Rotation of surface in degrees $\left(\mathrm{RMS}^{\circ}\right)$ & 0.05 & 0.02 & $<0.01$ \\
\hline Lordosis angle in degrees (ITL-ILS $^{\circ}$ ) & 0.05 & 0.02 & $<0.01$ \\
\hline Age (years) & 0.04 & 0.02 & $<0.05$ \\
\hline Pelvis curve in degrees & 0.04 & 0.02 & $<0.05$ \\
\hline
\end{tabular}

2) behavioral factors and factors related to an individual life style (poor medical and preventive activity, self-treatment, occupational peculiarities, rare appeal for medical aid etc.); 3) defects related to medical aid provision (poor quality of medical aid, absence of regular medical check-ups etc.) (Table 3).

Socioeconomic risk factors that cause DDSD occurrence and development. According to our regression analysis results, this category includes the following risk factors: social status $(b=0.43 ; p<0.001)$; age $(b=0.18 ; p<0001)$; occupation (labor) $(b=0.17$; $\mathrm{p}<0.01)$; limited financial means to preserve health and to get access to physical and health-improving activities $(b=0.15 ; \mathrm{p}<0.05)$; limited access to medications, preventive and health-improving activities that are necessary to preserve and improve health $(b=0.14 ; p<0.05)$. We analyzed impacts exerted by a social status on DDSD occurrence frequency and revealed that employed people tended to suffer from spondylogenic pain syndrome more frequently than unemployed people or students $(56.5 \%$ and $41.2 \% ; 2.3 \%$; $\left.\chi^{2}=10.2 ; \mathrm{p}<0.01\right)$. We detected that most examined patients had occupations that involved intellectual labor $(79.6 \%)$; those related to physical labor were much less frequent $(20.4 \%)$. And here we noted that people who dealt with intellectual labor tended to suffer from pains in the spine more frequently than those who dealt with physical labor (accordingly: $67.6 \%$ and $32.4 \%$; $\left.\chi^{2}=24.5 ; \mathrm{p}<0.001\right)$. Patients who dealt with predominantly intellectual labor and were employed in different spheres complained of spondylogenic pain syndrome with different frequency; we detected the following figures for different occupations: $27.0 \%$ for workers employed in education, medicine or people with creative labor; $20.3 \%$ for workers employed in retail and service sector; and $20.3 \%$ for workers occupying managerial positions or employed in economic and financial sphere $\left(\chi^{2}=12.2 ; \mathrm{p}<0.001\right)$. We should also note that only $30.1 \%$ patients stated all medications were available to them and they actively used such medications to treat DDSD. Only 19.8\% patients told they had sufficient financial means to get access to all necessary health-improving activity and DDSD treatment.

Personal and behavioral risk factors that cause DDSD occurrence and development. According to our regression analysis results, this category includes the following risk factors: patients not attending preventive medical check-ups $(b=0.20 ; p<0.01)$; rare appeal for medical aid $(b=0.18 ; p<0.01)$; appeal for medical aid to a wrong specialist when health deteriorates $(b=0.18 ; p<0.01)$; low literacy and absence of any knowledge on basic principles that explain how to treat and to prevent the 
Basic risk factors that cause DDSD occurrence and development in people living in Saint Petersburg (multiple regression with stepwise elimination)

\begin{tabular}{|l|c|c|c|}
\hline Factors causing development of the disease & $\begin{array}{c}\text { Regression } \\
\text { quotient b }\end{array}$ & $\begin{array}{c}\text { Standard } \\
\text { error } \mathrm{m}\end{array}$ & $\mathrm{p}$ \\
\hline \multicolumn{3}{|c|}{ Socioeconomic risk factors } \\
\hline Social status (students, employed, unemployed) & 0.43 & 0.10 & $<0.001$ \\
\hline Age & 0.18 & 0.06 & $<0.01$ \\
\hline Occupation and labor (physical or intellectual labor) & 0.17 & 0.03 & $<0.01$ \\
\hline $\begin{array}{l}\text { Limited financial means to preserve health and get access } \\
\text { to medical and health-improving procedures that are nec- } \\
\text { essary to preserve and improve health }\end{array}$ & 0.15 & 0.05 & $<0.05$ \\
\hline $\begin{array}{l}\text { Limited access to medications, preventive and health- } \\
\text { improving activities that are necessary to preserve and } \\
\text { improve health }\end{array}$ & 0.14 & 0.06 & $<0.05$ \\
\hline \multicolumn{4}{|c|}{ Personal and behavioral risk factors } \\
\hline Rare appeal for medical aid
\end{tabular}

disease $(b=0.17 ; p<0.05)$; proneness to selftreatment $(b=0.14 ; p<0.01)$; poor medical and preventive activity of patients $(b=0.12$; $\mathrm{p}<0.01$ ). In particular, only $30.5 \%$ patients suffering from spondylogenic pain syndrome knew what medications they had to take to prevent and treat DDSD. Only 3.1\% patients had groups consultations on how to prevent DDSD; however, most questioned patients $(84.0 \%)$ didn't think it was necessary.

Quality and availability of medical aid as a risk factor that causes DDSD occurrence and development. According to our regression analysis results, this category includes the following risk factors: poor availability of primary healthcare $(b=0.18 ; p<0.01)$; poor quality of preventive consultations $(b=0.15 ; p<0.01)$; rare prescription of medical, health-improving, and recovering procedures by doctors in a polyclinic $(b=0.14 ; p<0.05)$; rare and irregular interaction $\mathrm{n}$ between a doctor and a patient concerning the disease $(b=0.14 ; p<0.05)$; absence of regular medical check-ups in case of DDSD $(b=0.11 ; p<0.05)$.

Discussion. Available literature data indicate that in Russia there have been only few 
sporadic examinations on DDSD prevalence among population groups different as per age and sex $[15,16]$. Thus, there was a screening examination performed on 452 people, and its results revealed 56\% DDSD prevalence among adult population [3]. But at the same time, our screening research performed on 5,797 people revealed that DDSD could occur in $71.5 \%$ people older than 18 .

There was an epidemiologic examination with more than 46,000 questioned participants living in various European countries and Israel; its results revealed that 24\% respondents complained of spine pains with different localization. $18 \%$ adults living in Europe and Israel had pains in their lumbar spine, and 8\%, pains in their neck [22]. Epidemiologic research based on questioning was also performed in Russia $(n=3,998)$; the results revealed high prevalence of spondylogenic pain syndrome $(67.7 \%)$, including cases with temporary disability (36.7\%) [23]. There is an opinion that DDSD usually don't have any symptoms or any other subjective signs, and they are most frequently diagnosed only due to x-ray examinations [24]. In our research functional disorders were diagnosed in $100 \%$ participants $(n=5,797)$, and spondylogenic pain syndrome with variable intensity occurred in $71.5 \%$ examined patients. High prevalence of spondylogenic pain syndrome was also detected in other research $[12,25]$. According to the obtained data, pains in lumbar spine occurred most frequently $(41.3 \%)$ and it was well in line with data obtained in other research [26]. Spondylogenic pain syndrome turned out to more frequently occur in employed patients and it was not so frequent in unemployed ones and students $(56.5 \%$ and $41.2 \% ; 2.3 \%$; $\left.\chi^{2}=10.2 ; \mathrm{p}<0.01\right)$. Other research also revealed that pains in the spine more frequently occurred among employable people and it proved the issue was medically and socially significant [22]. Our research revealed that people occupied with intellectual labor complained of pains in the spine most frequently $(79.6 \%)$. On the contrary, other research indicated that DDSD and spondylogenic pain syndrome more frequently occurred in people occupied with physical labor [27].

The research detected primary factors that influenced DDSD occurrence and development; these factors were divided into 1) socioeconomic ones (social status, age, limited financial means to preserve health etc.); 2) behavioral factors and lifestylerelated factors (low medical and preventive activity, self-treatment, occupational peculiarities, rare appeal for medical aid, etc.); 3) factors related to poor quality and availability of medical aid (primary healthcare not being available, poor quality of preventive consulting provided for patients, absence of regular medical check-ups etc.). Most these factors are quite manageable; for example, proneness to self-treatment, rare appeal for medical aid, low literacy of population as regards the disease treatment and prevention, high body mass index, poor quality of medical aid, etc. There is other research that also revealed poor quality of medical aid provided for patients with DDSD. In particular, results obtained during research on medical aid quality revealed that it was proper only in $14 \%$ cases when patients with DDSD were treated. And most errors made by doctors were caused by non-optimal use of public healthcare resources when a disease was diagnosed; due to it, further errors occurred in the process of treating a patient [28]. And at the same time, timely examination and recovery therapy make for efficient treatment of spondylogenic pain syndrome as well as for significantly improved functional state of the spinal column in patients suffering from DDSD [1].

Vertebral pathology has its peculiarities and one of them is that doctors with variable specializations participate in its treatment, namely neurologists, physical therapists, therapists, rheumatologists, reflex therapists, manual therapists, homeopaths, and anesthesiologists [29]. Our research revealed that DDSD development is often influenced by 
patients appealing for medical aid to a wrong specialist $(b=0.18 ; p<0.05)$ thus putting themselves at risk that qualified medical aid would not be provided for them in due time.

Given the fact that socioeconomic situation in the society is improving gradually, activities aimed at providing social support for citizens are being enhanced and public healthcare is granted more financial resources, we can also consider such factors as limited financial means to preserve health and get access to medical and health-improving procedures $(b=0.14 ; p<0.05)$; and limited access to medications necessary for DDSD treatment $(b=0.14 ; p<0.05)$ to be quite manageable. Consequently, only age $(b=0.18$; $\mathrm{p}<0.05)$ can be considered unmanageable among all the analyzed risk factors that cause DDSD occurrence and development. Large multi-centered foreign research also revealed that age was a significant risk factor that caused DDSD development [2, 30]. Therefore, if we want to eliminate high morbidity with DDSD, we need a complex approach that involves socioeconomic growth, better quality and availability of medical aid, changes in ordinary lifestyle, and adjustment of manageable risk factors at individual level. Analysis of DDSD and spondylogenic pain syndrome prevalence among people living in Saint Petersburg allowed us to estimate how significant the problem was; the data which we obtained in our research can be applied for determining population demand for medical rehabilitation.

\section{Conclusions}

1. According to the results obtained in the screening examination, DDSD prevalence amounts to $71.5 \%$ among people living in Saint Petersburg. All the examined patients have functional disorders in the spinal column, the most frequent ones being lumbar lordotic angle $(81.2 \%)$, spine curve angle $(75.0 \%)$, and kyphosis angle $(67.9 \%)$ deviating from the physiological standard.

2. Patients suffering from DDSD most frequently complain of pains in the lumbar spine $(41.3 \%)$; pains in the thoracic spine $(15.4 \%)$, and the cervical spine $(14.7 \%)$ are less frequent. When spondylogenic pain syndrome occurs in a patient with DDSD, it can be related not only to functional disorders in the spinal column, but also to influences exerted by certain biological factors (age or high body mass index).

3. Occupational peculiarities also produce their effects on DDSD and spondylogenic pain syndrome $(b=0.17 ; p<0.01)$. In particular, this pathology more frequently occurs in people who are predominantly occupied with intellectual labor, and not with physical one $(67.6 \%$ and $\left.32.4 \% ; \chi^{2}=24.5 ; \mathrm{p}<0.001\right)$. DDSD and spondylogenic pain syndrome are more frequently detected in people employed in education and medicine, or people with creative occupations; they are less frequently detected in people employed in retail or service sector as well as in workers who occupy managerial positions or are employed in the sphere of economics and finance $\left(\chi^{2}=12.2 ; \mathrm{p}<0.001\right)$.

4. Most risk factors that influence DDSD occurrence and development are quite manageable: such factors are socioeconomic ones; personal and behavioral factors; quality and availability of medical aid. Timely examination, treatment and rehabilitation of patients with DDSD is a significant component in improving quality and availability of primary healthcare.

Funding. The research was not granted any sponsor support.

Conflict of interests. The authors state there is no any conflict of interests. 


\section{References}

1. Kreneva Yu.A., Panov V.P., Avdeeva M.V., Bogomolova K.A. Vosstanovitel'nyi potentsial kompleksnykh reabilitatsionnykh meropriyatii pri okazanii pervichnoi mediko-sanitarnoi pomoshchi bol'nym so spondilogennym bolevym sindromom [Restorative potential of complex rehabilitation in the primary health care provision for patients with degenerative disc diseases]. Profilakticheskaya $i$ klinicheskaya meditsina, 2018, no. 2, pp. 76-82 (in Russian).

2. Armbrecht G., Felsenberg D., Ganswindt M., Lunt M., Kaptoge S.K., Abendroth K. [et al.]. European Vertebral Osteoporosis Study and European Prospective Osteoporosis Study Groups. Degenerative inter-vertebral disc disease osteochondrosis intervertebralis in Europe: prevalence, geographic variation and radiological correlates in men and women aged 50 and over. Rheumatology (Oxford), 2017, no. 7, pp. 1189-1199.

3. Armbrecht G., Felsenberg D., Ganswindt M., Lunt M., Kaptoge S.K., Abendroth K. European Vertebral Osteoporosis Study and European Prospective Osteoporosis Study Groups. Vertebral Scheuermann's disease in Europe: prevalence, geographic variation and radiological correlates in men and women aged 50 and over. Osteoporos International, 2015, no. 10, pp. 2509-2519.

4. Muraki S., Oka H., Akune T., Mabuchi A., En-Yo Y., Yoshida M. et al. Prevalence of radiographic lumbar spondylosis and its association with low back pain in elderly subjects of populationbased cohorts: the ROAD study. Annals of the Rheumatic Diseases, 2009, no. 9, pp. 1401-1406.

5. Goode A.P., Marshall S.W., Renner J.B., Carey T.S., Kraus V.B., Irwin D.E. et al. Lumbar spine radiographic features and demographic, clinical, and radiographic knee, hip, and hand osteoarthritis. Arthritis Care and Research (Hoboken), 2012, no. 10, pp. 1536-1544.

6. Orel A.M. Vozrastnye aspekty epidemiologii degenerativno-distroficheskikh izmenenii mezhpozvonkovykh diskov po dannym sistemnogo analiza rentgenogramm pozvonochnika [Age aspects epidemiology of degenerative dystrophic changes intervertebral disks on data system analysis spine roentgenograms]. Meditsinskaya vizualizatsiya, 2010, no. 5, pp. 113-121 (in Russian).

7. Tae-Won J., Yeon-Soon A., Junsu B., Jong-In L., Kun-Hyung K., Youngki K.[et al.]. Lumbar intervertebral disc degeneration and related factors in Korean firefighters. BMJ Open, 2016, no. 6, pp. e011587.

8. Vyalkov A.I., Gusev E.I., Zborovskii A.B., Nasonova V.A. Osnovnye zadachi Mezhdunarodnoi Dekady (the bone and joint decade 2000-2010) v sovershenstvovanii bor'by s naibolee rasprostranennymi zabolevaniyami oporno-dvigatel'nogo apparata $\mathrm{v}$ Rossii [Basic objectives of international «The bone and joint decade 2000-2010» in improvement of the measures against the most prevalent diseases of locomotor system in Russia]. Nauchno-prakticheskaya revmatologiya, 2001, no. 2, pp. 4-8 (in Russian).

9. Delitto A., George S.Z., Dillen L.V., Whitman J.M., Sowa G.A., Shekelle P. [et al.]. Low Back Pain: Clinical Practice Guidelines Linked to the International Classification of Functioning, Disability, and Health from the Orthopaedic Section of the American Physical Therapy Association. Journal of Orthopaedic \& Sports Physical Therapy, 2012, no. 4, pp. 1-57.

10. Hoy D., Brooks P., Blyth F., Buchbinder R. The Epidemiology of low back pain. Best Practice and Research: Clinical Rheumatology, 2010, no. 6, pp. 769-781.

11. Khetagurova Z.V., Gabaraeva L.N., Totrov I.N., Albegova Z.A. Struktura i chastota bolei v nizhnei chasti spiny sredi vzroslogo naseleniya [Structure and frequency of pains in the lower part of the back among adult population]. Nauchno-prakticheskaya revmatologiya, 2006, no. 2, pp. 118-119 (in Russian).

12. Tyurnikov V.M. Degenerativno-distroficheskie porazheniya pozvonochnika: diagnostika, klinika i lechenie [Degenerative-dystrophic lesions of the spine: diagnosis, clinic and treatment]. Russkii meditsinskii zhurnal. Nevrologiya Psikhiatriya, 2008, no. 26, pp. 17-46 (in Russian).

13. Povoroznyuk V.V. Bol' v nizhnei chasti spiny. Rasprostranennost', prichiny, mekhanizmy razvitiya i osobennosti diagnostiki [Pain in the lower back. Prevalence, causes, developmental mechanisms and diagnostic features]. Bol', sustavy, pozvonochnik, 2011, no. 1, pp. 13-22 (in Russian). 
14. Penina G.O. Ob"ektivizatsiya nevrologicheskikh proyavlenii osteokhondroza poyasnichnogo otdela pozvonochnika u zhitelei severnykh territorii [Objectification of neurological manifestations of osteochondrosis of the lumbar spine among residents of northern territories]. Bulletin of the International Scientific Surgical Association, 2006, no. 3, pp. 37-38 (in Russian).

15. Vyshlova I.A., Karpov S.M., Starodubtsev A.I. Vertebrogennye bolevye sindromy poyasnichnogo urovnya: epidemiologiya, klinicheskie proyavleniya [Low back pain syndrome: epidemiology and clinical manifestations]. Meditsinskii vestnik Severnogo Kavkaza, 2016, no. 4, pp. 586-587 (in Russian).

16. Osipov A.V., Chechenin A.G., Kolbasko A.V., Onishchenko A.L. Rasprostranennost' nevrologicheskikh proyavlenii poyasnichnogo osteokhondroza u teleutov korennogo sel'skogo naseleniya Kemerovskoi oblasti [Prevalence OF neurological manifestation lumbar osteochondrosis in primary population of Kemerovo region - teleuts]. Acta Biomedica Scientifica, 2013, no. 90, pp. 44-47 (in Russian).

17. Povzun A.S., Kisel'gof O.G., Povzun K.A., Alimov R.R., Miroshnichenko A.G. Osteokhondroz: analiz gospitalizatsii patsientov s ostrym bolevym sindromom [Osteochondrosis: analysis of hospitalization of patients with acute pain]. Skoraya meditsinskaya pomoshch', 2014, no. 4, pp. 61-64 (in Russian).

18. Oleinik A.D., Zarudskii A.V., Firsova N.V. Rannyaya diagnostika razlichnykh form poyasnichnogo osteokhondroza [Early diagnostics of different forms of the lumbar osteochondrosis]. Statsionarozameshchayushchie tekhnologii: Ambulatornaya khirurgiya, 2007, no. 4, pp. 158-159 (in Russian).

19. Podchufarova E.V., Razumov D.V. Rol' bolevogo povedeniya v formirovanii invalidizatsii u patsientov s khronicheskoi bol'yu v spine [The role of painful behavior in the formation of disability in patients with chronic pain in the back]. Rossiiskii meditsinskii zhurnal, 2010, no. 3, pp. 11-18 (in Russian).

20. Harzmann H.. Stellenwert der Videorasterstereografie als schulärztliche Screeningmethode von skoliotischen Fehlhaltungen und strukturellen Skoliosen. Dissertation. München, LudwigMaximilians-Universität Publ., Medizinische Fakultät, 2000.

21. Schröder J. Stiller T. Mattes, K. Referenzdaten in der Wirbelsäulenformanalyse. Manuelle Medizin, 2011, no. 49, pp. 161-166.

22. Siddall P.J., Cousins M.J., Otte A., Griesing T., Chambers R., Murphy T.K. Pregabalin in central neuropathic pain associated with spinal cord injury: a placebo-controlled trial. Neurology, 2006, no. 10, pp. 1792-1800.

23. Dorohov A.V., Dac L.S., Men'shikova L.V. Rasprostranennost' bolei v spine sredi podrostkov i vzroslogo naseleniya g. Irkutska [The prevalence of back pain among adolescents and adults of Irkutsk]. Sibirskii meditsinskii zhurnal (Irkutsk), 2007, no. 7, pp. 111-113 (in Russian).

24. Ibragimov A., Avezova G.S. Meditsinskaya i sotsial'naya znachimost' problemy poyasnichnogo osteokhondroza [Medical and social significance of the problem of lumbar osteochondrosis]. European Association of pedagogues and psychologists «Science», 2017, pp. 151-153 (in Russian).

25. Adambaev Z.I., Kilichev I.A. Vostrebovannost' statsionarzameshchayushchikh ambulatoriev v lechenii i reabilitatsii bol'nykh s degenerativnymi zabolevaniyami pozvonochnika v Uzbekistane [The demand stationer of ambulatories in the treatment of and rehabilitation of patients with degenerative diseases of the spine in Uzbekistan]. Problemy sovremennoi nauki i obrazovaniya, 2016, no. 5, pp. 231-236 (in Russian).

26. Vieira L.A., Dos Santos A.A., Peluso C., Barbosa C.P., Bianco B., Rodrigues L.M.R. Influence of lifestyle characteristics and VDR polymorphisms as risk factors for intervertebral disc degeneration: a case-control study. European Journal of Medical Research, 2018, no 23, pp. 11.

27. Safina A.G., Stepuk N.V., Raimkulova H.B., Raimkulova K.B., Zarpullaev Zh.Sh., Bhat N.A Kliniko-epidemiologicheskie pokazateli dorsalgii [Clinical and epidemiological indicators of dorsalgia]. Vestnik KazNMU, 2012, no. 3, pp. 59-62 (in Russian). 
28. Analiz kachestva meditsinskoi pomoshchi patsientam s degenerativno-distroficheskimi zabolevaniyami pozvonochnika v Sankt-Peterburge [Analysis of the quality of care for patients with degenerative-dystrophic diseases of the spine in St. Petersburg]. Tyumenskii meditsinskii zhurnal, 2012, no. 2, pp. 28-29 (in Russian).

29. Krut'ko A.V., Bedoreva I.Yu., Shalygina L.S., Kislitsyna L.V. Sovershenstvovanie organizatsii meditsinskoi pomoshchi patsientam s degenerativno-distroficheskimi zabolevaniyami poyasnichnogo otdela pozvonochnika [Improving the organization of medical care for patients with degenerative-dystrophic diseases of the lumbar spine]. Problemy sotsial'noi gigieny, zdravookhraneniya $i$ istorii meditsiny, 2012, no. 2, pp. 26-31 (in Russian).

30. Koji A., Tomomi Y., Nozomu I., Akinobu N., Akihiro S. Risk factors for lumbar intervertebral disc height narrowing: a population-based longitudinal study in the elderly. BMC Musculoskelet Disorders, 2015, no. 16, 344 p.

Avdeeva M.V., Kreneva Yu.A., Panov V.P., Filatov V.N., Mel'tser A.V., Karasaeva L.A. Risk factors that cause development and progression of degenerative and dystrophic diseases in the spinal column as per results obtained during screening tests on people living in saint petersburg. Health Risk Analysis, 2019, no. 1, pp. 125-134. DOI: 10.21668/health.risk/2019.1.14.eng

Received: 30.01 .2019

Accepted: 24.02.2019

Published: 30.03 .2019 
UDC 616.127-005.8-059-06-092.12

DOI: 10.21668/health.risk/2019.1.15.eng

Read

\title{
PATIENT AFTER CARDIAC INFARCTION: RISK FACTORS THAT CAN CAUSE NEW CARDIOVASCULAR DISASTERS
}

\author{
I.A. Novikova, L.A. Nekrutenko, T.M. Lebedeva, O.V. Kchlynova, E.A. Shishkina \\ E.A. Vagner's Perm State Medical University of the RF Public Healthcare Ministry, 26 Petropavlovsjaya Str., \\ Perm, 614000, Russian Federation
}

\begin{abstract}
Over recent years there has been a trend for a decrease in lethality during an acute cardiac infarction period; but at the same time there is a growth in a number of patients who run high risks of recurrent adverse cardiovascular events. Despite secondary prevention measures having been introduced, frequency of recurrent cardiac infarctions is still high, and most of them occur during the first year. Our research goal was to reveal basic risk factors that cause recurrent adverse cardiovascular events in patients during the first year after a cardiac infarction. We questioned 40 patients living in Perm who had had cardiac infractions from September 2017 to July 2018 and who were undergoing polyclinic rehabilitation. To perform this questioning, we applied an original questionnaire.

We revealed that men prevailed among patients with cardiac infarction. The first infarction usually occurs in early 60ties. Ischemic heart disease starts with cardiac infarction in $45 \%$ patients. We detected that at least one risk factor occurred for all the patients; the most widely spread risk factors in the given population were burdened heredity, low physical activity, overweight, uncontrolled arterial hypertension, and hypercholesterolemia. We also revealed in our research that less than $50 \%$ patients were committed to treatment and it was primarily due to low awareness about the necessity to take medications and also due to these medications being hardly affordable for patients. Therefore, patients who suffered from cardiac infarction and are undergoing polyclinic rehabilitation run an elevated risk of recurrent cardiovascular events during the first year and it means that secondary prevention measures are not efficient. When treating patients with cardiac infarction, we should optimize interaction between a physician and a patient and pay greater attention to a patient being committed to treatment.

Key words: cardiac infarction, recurrent cardiac infarction, risk factors, revascularization, rehabilitation, commitment to treatment, secondary prevention.
\end{abstract}

Cardiac infarction (CI) is the most severe type of ischemic heart disease (IHD). Nevertheless, there have been positive trends detected recently in treating patients with acute CI such as percutaneous coronary interventions (PCI) which are performed promptly and early application of antithrombocytic medications, betaadrenoceptor blocking drugs, inhibitors of angiotensin converting enzyme (ACE), and statins. It has led to a reduction in lethality that is observed at present [1-4]. However, longer life span and a growth in number of patients who have survived after their first CI results in greater risks of new cardiovascular disasters.
In spite of secondary prevention activities being implemented in significant scopes, frequency of recurrent CI still remains high. As per data provided by different authors, patients with recurrent CI account for $14-41.6 \%$ of the overall number of people who have been hospitalized with diagnosed CI [5-8]. Up to $40 \%$ of all recurrent CI occur during the first year [9]. As a rule, patients with recurrent $\mathrm{CI}$ run higher risks of unfavorable outcome [8, 10-11] due to a greater number of probable complications. Still, most scales showing CI risks usually give an idea of only a short-term forecast [12-14], and when such patients are provided with am-

(C) Novikova I.A., Nekrutenko L.A., Lebedeva T.M., Kchlynova O.V., Shishkina E.A., 2019

Irina A. Novikova - External Researcher at the Hospital Therapy Department (e-mail: Nurdus@yandex.ru; tel.: +7 (342) 239-31-88; ORCID: http://orcid.org/0000-0002-3968-6498).

Ludmila A. Nekrutenko - Doctor of Medicine, Professor at the Hospital Therapy Department (e-mail: lunekru@mail.ru; tel.: +7 (342) 239-31-88; ORCID: http://orcid.org/0000-0001-9151-8195).

Tatyana M. Lebedeva - Doctor of Medicine, Professor at the Department for Public Health and Healthcare (e-mail: super.oziz@yandex.ru; tel.: +7 (342) 236-12-56; ORCID: http://orcid.org/0000-0003-3374-8982).

Olga V. Kchlynova - Corresponding Member of the RAS, Doctor of Medicine, Professor, Head of the Hospital Therapy Department (e-mail:olgakhlynova@mail.ru; tel.: +7 (342) 239-31-88; ORCID: https://orcid.org/0000-0003-4860-0112).

Ekaterina A. Shishkina - Candidate of Medical Science, Associate Professor at the Hospital Therapy Department (e-mail:doctor.shishkina@yandex.ru; tel.: +7 (342) 239-31-88; ORCID: http://orcid.org/0000-0001-6965-7869). 
bulatory care, comparatively small attention is paid to assessing their risk factors [15].

As per data taken from an acute coronary syndrome (ACS) register in Kemerovo region [16], 26.5\% of all patients observed for 5 years had recurrent CI, $40 \%$ of all these disease cases occurred during the first year, and it confirms data provided by the Emergency Cardiology Department at Sklifosovskiy Research Institute of Emergency Care which are given above [9]. Recurrent CI resulted in fatal outcome in $18.4 \%$ cases. Authors spot out several risk factors that can cause recurrent $\mathrm{CI}$; they are age, poor education and low standard of living, hypodynamia, and multi-focal atherosclerosis. Patients with recurrent CI can have other risk factors such as family case history burdened with IHD (70\%), hypercholesterolemia $(60.8 \%)$, arterial hypertension $(68 \%)$, overweight or obesity (71.4\%), smoking (61.6\%), and pancreatic diabetes $(20.8 \%)$. However, there were no significant discrepancies as per most abovementioned parameters between patients with recurrent $\mathrm{CI}$ and those who had their first CI.

A prospective cohort study accomplished in Novosibirsk revealed that $31.7 \%$ recurrent CI also occurred during the first year [17]. Men prevailed among patients with recurrent CI (59.2\%); arterial hypertension occurred in 96.1\% cases; smoking, 38.8\%; heredity burdened as per arterial hypertension and IHD, $76.3 \%$ and $52.5 \%$ respectively; average level of total cholesterol amounted to $5.9 \pm 1.2 \mathrm{mmol} / \mathrm{l}$, average body mass index (BMI) was equal to $32.2 \pm 4.8 \mathrm{~kg} / \mathrm{m}^{2}$.

In Yakutia, risk factors prevalence also remains high among patients after their first CI. 12 months after CI $62.2 \%$ have hypercholesterolemia; $35.6 \%$, carbohydrate metabolism disorders; $26.7 \%$, BMI $\geq 30 \mathrm{~kg} / \mathrm{m}^{2}$; $75.6 \%$ have abdominal obesity, and $46.7 \%$ patients smoke [18].

Let's overview some foreign data. A study accomplished in Albania revealed that patients with recurrent CI more frequently suffered from heart failure, low ejection fraction of the left ventricle, and multi-vessel coronary artery disease [19]. They were less frequently given medications with a solid evidential base and underwent revascularization rather rarely. But overall, prevalence of risk factors (arterial hypertension, hypercholesterolemia) practically had no discrepancies in patients with recurrent CI and those with their first CI.

A study performed in China revealed some independent risk factors that could cause recurrent $\mathrm{CI}$; they were age, pancreatic diabetes, and reperfusion [20]. In-hospital lethality was higher among patients with recurrent CI.

We should note that some foreign researchers assess risk factors only for combined end points without separately spotting out recurrent CI. Thus, a study performed in Sweden called HELICON highlighted the following risk factors of unfavorable cardiovascular events in patients a year after CI: age (60 and older), pancreatic diabetes, heart failure, and a failure to conduct revascularization during CI [21].

So, most authors indicate several risk factors that can cause recurrent $\mathrm{CI}$; they are age, hypercholesterolemia, carbohydrate metabolism disorders, overweight, smoking, heart failure, and failure to conduct revascularization.

International recommendations on how to treat patients with CI include secondary prevention that involves changes in a lifestyle (giving up smoking, losing weight until BMI is within standards, etc.), taking statins, applying double antithrombocytic therapy, taking drugs that block renin-angiotensin-aldosterone system and beta-adrenoceptor blocking drugs. 4S, CARE and LIPID research revealed that when patients who had cardiac infarction in their case history took statins, it lead to a $30 \%$ decrease in lethality, new cardiac infarction cases, and necessity in myocardial revascularization [22-24]. A significant decrease in lethality resulted from patients taking aspirin as it was shown in ISIS-2 research [25]. When drugs that blocked P2Y12-recepotors of platelets (clopidogrel, ticagrelor) were added to aspirin, it led to even greater reduction in lethality $[26,27]$. ACE inhibitors were also thoroughly examined, and positive effects produced by them that caused greater decrease in lethality were described in detail [28, 29]. Nowadays they should be obligatory applied 
for treating patients suffering from CI with a rise in ST segment, with front CI, lower left ventricular ejection fraction, heart failure, arterial hypertension, and pancreatic diabetes. Beta-adrenoceptor blocking drugs reduce oxygen requirements by the cardiac muscle and improve blood flow redistribution from the epicardium to the cardiac muscle thus making an infarct zone smaller and stimulating patients' survival. Clinical research demonstrated a considerable decrease in lethality as well as reduced number of ventricular arrhythmia and less frequent recurrent infarctions [30]. These effects were persistent over a long-term period when beta-adrenoceptor blocking drugs were taken orally.

But still, patients' commitment to following recommendations given by their doctors remains rather poor. Meanwhile, there are data indicating that if a patient stops taking necessary medications after $\mathrm{CI}$, it results in higher morbid risks; for example, OR was equal to 1.82 after aspirin withdrawal; 1.96, beta-adrenoceptor blocking drugs withdrawal; 2.86, statins withdrawal; and 3.81 after three medications withdrawal (aspirin, beta-adrenoceptor blocking drug, and statin) [31]. Some authors consider poor commitment to treatment as a risk factor that can cause recurrent ischemic disasters. Thus, the above mentioned ACS register in Kemerovo region contains data on only $28.8 \%$ with recurrent CI who received double antithrombocytic therapy during a year; over a 5 -year period $22 \%$ patients didn't take statins, and $16 \%$ didn't take beta-adrenoceptor blocking drugs [16]. As per data taken from the Russian register RECORD, $18 \%$ patients who had CI stopped their treatment with double antithrombocytic therapy during the first year after the disease [32]. Research that focused on assessing commitment to therapy after Q-positive CI among Yakuts revealed a decrease in number of patients who took drugs by the end of the first year; thus, only $45 \%$ took aspirin; $40 \%$, a drug that blocked P2Y12-receptors of platelets; $41 \%$, beta-adrenoceptor blocking drugs; 33\%, ACE inhibitors/sartans; 39\%, statins [18].

Our research goal was to detect basic risk factors that could cause recurrent cardiovascu- lar disasters in patients during the first year after cardiac infarction in a big industrial city.

Data and methods. Our research object was Perm, a regional center with 1 million population, a territory with industrial and transport burdens being typical for Russia. We set the following basic criteria for patients to be included into our study: cardiac infarction diagnosed according to the Third universal definition of cardiac infarction [33]; absence of acute pathology, exacerbations of chronic diseases, arrhythmias, systemic diseases, and grave disorders in liver and kidneys functioning. To perform our study, we applied an original questionnaire. Overall, 40 patients were questioned; they all had had cardiac infarction from 3 to 12 months prior to the study (from September 2017 to July 2018) and were undergoing polyclinic rehabilitation. All participants permanently lived in Perm. We analyzed the following parameters: sex; age; applying to a doctor due to a cardiovascular disease (CVD) prior to $\mathrm{CI}$; time which passed since the first symptoms occurred till a patient applied for medical aid; revascularization procedure; what drugs were recommended by a doctor; whether a patient followed a doctor's recommendations or not; heredity; body mass index; physical activity; blood pressure; total cholesterol in blood; dextrose in blood; smoking status.

We assessed burdened heredity as per IHD cases in a patient's family which occurred in men younger than 55 and women younger than 65. BMI was calculated as per Quetelet formula. According to WHO recommendations, we considered BMI equal to $25-30 \mathrm{~kg} / \mathrm{m}^{2}$ an overweight; $30-35 \mathrm{~kg} / \mathrm{m}^{2}$, Obesity Class I; $35-40 \mathrm{~kg} / \mathrm{m}^{2}$, Obesity Class II, $40 \mathrm{~kg} / \mathrm{m}^{2}$ and more, Obesity Class III. Physical activity was considered to be low if a patient spent less than 30 minutes a day on it. Blood pressure equal to $\geq 140 / 90 \mathrm{~mm} \mathrm{Hg}$ meant a patient had arterial hypertension; if total cholesterol in blood was $\geq 4 \mathrm{mmol} / \mathrm{l}$, we considered that a patient had hypercholesterolemia given a very high risk of cardiovascular complications after $\mathrm{CI}$; dextrose in venous blood plasma equal to $\geq 6.1 \mathrm{mmol} / 1$ meant there was a disorder in dextrose level in blood plasma on an empty stomach. 
Characteristics of patients who had cardiac infarction $(n=40)$

\begin{tabular}{|c|c|c|}
\hline Parameter & Measure & \\
\hline \multirow[t]{2}{*}{ Sex } & men, \% & 55.0 \\
\hline & women, \% & 45.0 \\
\hline \multirow[t]{3}{*}{ Age (years) } & total, year & $65.7 \pm 9.9$ \\
\hline & men, years & $63.5 \pm 7.6$ \\
\hline & women, years & $68.3 \pm 12.0$ \\
\hline $\begin{array}{l}\text { Attended a doctor due to cardiac pathology prior } \\
\text { to cardiac infarction }\end{array}$ & share, $\%$ & 55.0 \\
\hline Cardiac infarction in case history & share, $\%$ & 15.0 \\
\hline Commitment to treatment before cardiac infarction & share, $\%$ & 63.6 \\
\hline $\begin{array}{l}\text { Average period of time that passed before a pa- } \\
\text { tient applied for a medical aid }\end{array}$ & hours & $111.5 \pm 201.0$ \\
\hline \multirow[t]{3}{*}{ Treatment tactics during hospitalization } & drug therapy, share, $\%$ & 40.0 \\
\hline & stenting, share, $\%$ & 55.0 \\
\hline & coronary artery bypass surgery, share, $\%$ & 5.0 \\
\hline Commitment to treatment after cardiac infarction & share, $\%$ & 45.0 \\
\hline \multirow[t]{7}{*}{ Risk factors } & burdened heredity, share, $\%$ & 65 \\
\hline & body mass index $\geq 25 \mathrm{~kg} / \mathrm{m}^{2}$, share, $\%$ & 68.4 \\
\hline & smoking, share, $\%$ & 15.0 \\
\hline & low physical activity, share, $\%$ & 25.0 \\
\hline & arterial hypertension, share, $\%$ & 43.75 \\
\hline & hypercholesterolemia, share, $\%$ & 55.6 \\
\hline & $\begin{array}{l}\text { dextrose in blood plasma on an empty } \\
\text { stomach }>6.1 \mathrm{mmol} / 1, \text { share, } \%\end{array}$ & 33.3 \\
\hline
\end{tabular}

Calculations and graphical analysis were performed with applied Microsoft Excel software. Quantitative parameters are given as a simple mean \pm standard deviation; qualitative parameters are given as frequencies in per cent.

Results and discussion. Table 1 contains an overall characteristics of patients who had cardiac infarction.

Men prevailed in this group of patients with $55 \%$ against $45 \%$ women. IHD revealed itself for the first time with CI in $45 \%$ patients and it is in line with data obtained in the country as a whole [34]. The first CI occurs in the first half of the 6th decade, or at $63.8 \pm 9.7$, and it usually happens a bit earlier to men (63.5 \pm 7.6$)$ than to women $(64.0 \pm 12.3$ лет). The obtained data are quite similar to sex and age structure of patients with CI included into RECORD 3 register in Perm region [35, 36].

A greater attention should be paid to insufficient primary PCI as only 55\% patients underwent such procedures. This is probably due to patients applying for medical aid too late when a lot of time has passed since the first symptoms occurred (Figure 1). About one third of patients are placed in a hospital after two or even more days and it is beyond a time span suitable for performing primary PCI [37].

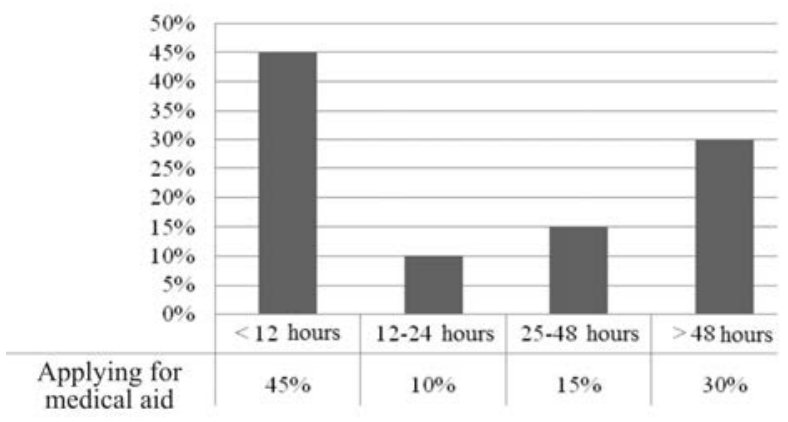

Figure 1. Time that passed from the first symptoms to a moment of applying for medical aid

We analyzed risk factors prevalence in patients during rehabilitation after $\mathrm{CI}$ and revealed that at least one risk factor was present in all of them. More than a half patients had burdened heredity as per cardiovascular dis- 
ease; one fourth had low physical activity in spite of not having any concomitant somatic pathology. Each seventh patient was an active smoker. $80 \%$ patients measured their blood pressure regularly and its values didn't correspond to the standard in half of them.

$60 \%$ patients knew dextrose level in their blood, but only $45 \%$ knew the figure for total cholesterol. One third of patients who controlled these parameters had disorders in dextrose level on an empty stomach, and more than a half of them had hypercholesterolemia. $31.6 \%$ patients had overweight; $10.5 \%$, Obesity Class I; $21.1 \%$, Obesity Class II; 5.3\%, Obesity Class III.

We analyzed patients' commitment to treatment and revealed that more than a half patients who had undergone CI didn't follow their doctors' recommendations. Men were less committed to treatment than women, with $41.7 \%$ against $50 \%$. Patients were the least committed to taking statins and drugs that blocked P2Y12-recetors of platelets (Figure 2). We should note that such drugs are recommended to be taken by all patients who had CI as opposed to, for example, ACE inhibitors as such drugs are to be taken only in some specific situations described above. As regards reasons for low commitment to treatment, we should highlight that more than one third of patients stated they were not sufficiently aware of the necessity to take drugs. Each fifth patient also mentioned that affordability of a drug was truly important (Figure 3).

Conclusions. So, patients who had cardiac infarction and who are undergoing polyclinic rehabilitation run high risks of recurrent cardiovascular disasters during the first year. An examined group of risk factors includes both factors that can't be modified and factors that can; among the latter we can mention such most frequent ones as low physical activity, overweight, hypercholesterolemia, and arterial hypertension. Such prevalence of risk factors indicates that secondary prevention activities are not efficient.

Conclusion. Efficient treatment of patients with CI during rehabilitation is truly vital nowadays and it should necessarily include

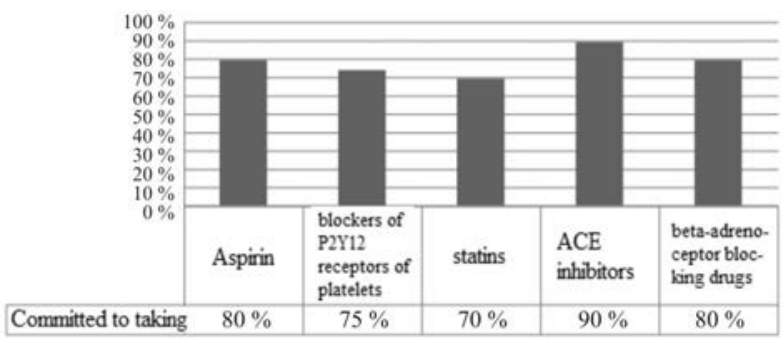

Figure 2. Patients' commitment to taking various drugs

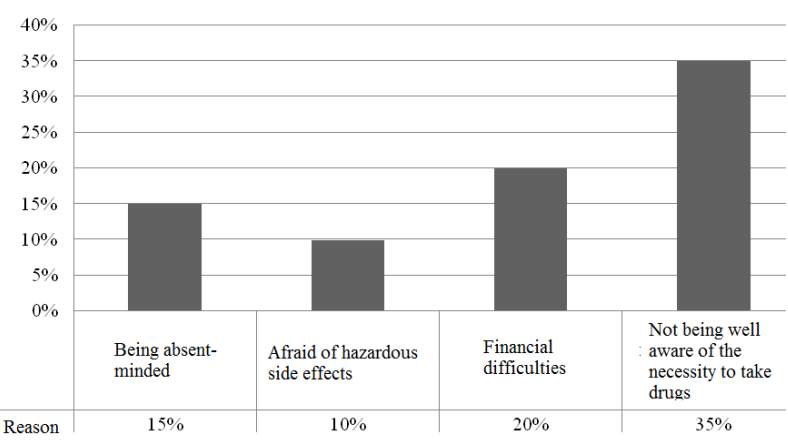

Figure 3. Reasons for low commitment to treatment

elimination or correction of risk factors that can cause recurrent cardiovascular disasters. Patients' life quality and long-term forecast of their survival depend on it to a great extent.

Low commitment to treatment, both before and after CI, is a basic problem related to secondary prevention. It occurs, first of all, due to doctors not giving their patients enough information about significance and necessity of taking drugs and correcting risk factors that can be modified.

Let us consider foreign experience in the sphere. Thus, in the USA highly qualified nurse practitioners are in great demand due to physicians being overloaded with work. Such specialists, in case of necessity, can provide uninterrupted observation over patients and make healthcare more available. First, a doctor examines a patient with CI after a release from a hospital. At this stage he or she determines what patients have the gravest problems, run risks of high co-morbidity and therefore need more frequent observation. A team approach to ambulatory care is applied to such patients; it means that highly qualified nurse practitioners help doctors monitor health of such patients and teach them how to pursue a healthier 
lifestyle. It can make for more efficient secondary prevention; in particular, greater commitment to taking statins was detected and more patients decided to give up smoking [38].

Similar practice was also implemented within Leonardo project in Apulia, Italy, where medical care managers, or specially trained nurses, took care of patients who suffered from grave chronic cardiovascular disease and pancreatic diabetes. Their responsibilities were to correct patients' lifestyle, to observe their health state and to provide them with necessary medical information. It resulted in great improvement of clinical parameters among patients who could now control their diseases more efficiently [39].

Low commitment to treatment is dealt with in Norway via greater inclusions of patients into cardiorehabilitation programs, more detailed information provided in leaflets given by general practitioners as regards risk factors, treatment goals, quantity and periodicity of visits to a doctor, as well as greater attention drawn to a smoking status of a patient [40].

In Taiwan great attention is paid to a period of time just after a release from a hospital as a patient is the most vulnerable during it [41]. A patient should visit a doctor during the first 7 days after a release from a hospital, and it should be noted, that in most cases a doctor who treated a patient in a hospital, continues to observe him or her afterwards. It helps to reduce a number of recurrent hospitalization as a doctor is better aware of some individual pecu- liarities a patient has and it also makes drug therapy more efficient.

These examples are quite interesting and can be implemented in Russia. Doctors in hospitals and polyclinics should pay greater attention to consulting their patients and clarifying treatment goals to them; they should give them written instructions with clear indication how often to visit a doctor, what changes to make in a lifestyle, and what drugs to take, and the effect will be better if a doctor and a patient first talk all these matters over, at least briefly. It is also advisable that a patient is attended to by the same doctor during the whole period of ambulatory care since it guarantees that this doctor is better aware about dynamics of a patient's state and knows what peculiarities a clinical course of the diseases has in this particular patient. If functional responsibilities carried by nurses are extended as regards observation over cardiologic patients who run higher risks, it can also be quite useful as it will allow to relieve doctors of some workloads and to provide greater commitment to treatment. Therefore, if we manage to optimize interaction between medical staff and patients, it will help to manage risks of recurrent cardiovascular disasters more efficiently.

Funding. The research was not granted any sponsor support.

Conflict of interests. The authors state there is no any conflict of interests.

\section{References}

1. Sulo E., Vollset S.E., Nygard O., Sulo G., Igland J.[et al.]. Trends in 28-day and 1-year mortality rates in patients hospitalized for a first acute myocardial infarction in Norway during 2001-2009: a "Cardiovascular disease in Norway" (CVDNOR) project. Journal of Internal Medicine, 2015, no. 277, pp. 353-361.

2. Koopman C., Bots M.L., van Oeffelen A.A., van Dis I., Verschuren W.M., Engelfriet P.M. [et al.]. Population trends and inequalities in incidence and short-term outcome of acute myocardial infarction between 1998 and 2007. International Journal of Cardiology, 2013, no. 168, pp. 993-998.

3. Schmidt M., Jacobsen J.B., Lash T.L., Botker H.E., Sorensen H.T. 25 year trends in first time hospitalisation for acute myocardial infarction, subsequent short and long term mortality, and the prognostic impact of sex and comorbidity: a Danish nationwide cohort study. BMJ, 2012, vol. 344, pp. 356-364.

4. Dudas K., Lappas G., Rosengren A. Long-term prognosis after hospital admission for acute myocardial infarction from 1987 to 2006. International Journal of Cardiology, 2012, no. 155, pp. 400-405. 
5. Strelchenko O.V. Osnovnye pokazateli zdorov'ya naseleniya i zdravookhraneniya Sibirskogo federal'nogo okruga v 2012 godu. Sbornik statisticheskikh i analiticheskikh materialov. [The main indicators of public health and health care of the Siberian Federal District in 2012. Digest of statistical and analytical materials. Release 12]. Novosibirsk: Ofset, 2013, pp. 332 (in Russian).

6. Wagner S., Burczyk U., Schiele R. [et al.]. The 60 minutes myocardial infarction project: characteristics on admission and clinical outcome in patients with reinfarction compared to patients with a first infarction. European Heart Journal, 1998, no. 19, pp. 879-884.

7. Natali A., Vichi S., Landi P. [et al.]. Mortality from coronary heart disease in subjects with type 2 diabetes and in non-diabetic subjects with and without prior myocardial infarction. The New England Journal of Medicine, 1998, no. 339, pp. 229-234.

8. Motivala A.A., Tamhane U., Ramanath V.S. [et al.]. A prior myocardial infarction: how does it affect management and outcomes in recurrent acute coronary syndromes? Clinical Cardiology, 2008, no. 31, pp. 590-596.

9. Volkova E.G., Malykhina O.P., Levashov S.Yu. Povtornye infarkty miokarda: osobennosti izmeneniya soderzhaniya biomarkerov i remodelirovaniya miokarda (issledovanie sluchai-kontrol'). Kardiologiya, 2007, no.7, pp. 26-28 (in Russian).

10. Shiraishi J., Kohno Y., Sawada T. [et al.]. Predictors of in-hospital outcome after primary percutaneous coronary intervention for recurrent myocardial infarction. Circulation Journal, 2008, no. 72 , pp. $1225-1229$.

11. Shotan A., Blondheim D.S., Gottlieb S. [et al.]. Comparison of outcome of recurrent versus first ST-segment elevation myocardial infarction (from National Israel Surveys 1998 to 2006). American Journal of Cardiology, 2011, no. 107, pp. 1730-1737.

12. Antman E.M., Cohen M., Bernink P.J. [et al.]. The TIMI risk score for unstable angina/nonST elevation MI: A method for prognostication and therapeutic decision making. The Journal of the American Medical Association, 2000, vol. 284, no. 7, pp. 835-842.

3. Boersma E., Pieper K.S., Steyerberg E.W. [et al.]. Predictors of outcome in patients with acute coronary syndromes without persistent ST-segment elevation. Results from an international trial of 9461 patients. The PURSUIT Investigators. Circulation, 2000, vol. 101, no. 22, pp. 2557-2567.

14. Fox K.A., Dabbous O.H., Goldberg R.J. [et al.]. Prediction of risk of death and myocardial infarction in the six months after presentation with acute coronary syndrome: prospective multinational observational study (GRACE). BMJ, 2006, vol. 333, no. 7578, pp. 1091-1094.

15. Eagle K.A., Lim M.J., Dabbous O.H. [et al.]. A validated prediction model for all forms of acute coronary syndrome: estimating the risk of 6-month postdischarge death in an international registry. The Journal of the American Medical Association, 2004, vol. 291, no. 22, pp. 2727-2733.

16. Barbarash O.L., Sedykh D.Yu., Gorbunova E.V. Osnovnye faktory, opredelyayushchie risk razvitiya povtornogo infarkta miokarda // Serdtse: zhurnal dlya praktikuyushchikh vrachei, 201, vol. 16 , no. 1 , pp. 10-50 (in Russian).

17. Negmadzhonov U.U., Kuimov A.D. Povtornye infarkty miokarda: faktory riska, klinika, lechenie [Recurrent myocardial infarction: risk factors, clinic, treatment]. Meditsina i obrazovanie $v$ Sibiri: elektronnyi nauchnyi zhurnal, 2011, no. 6. Available at: http://www.ngmu.ru/cozo/mos/article/text full.php?id=548 (23.12.2018) (in Russian).

18. Kylbanova E.S., Gur'eva E.V., Pavlova A.V. Chastota vstrechaemosti faktorov riska i priverzhennost' k medikamentoznoi terapii u yakutov, perenesshikh Q-pozitivnyi infarkt miokarda [The frequency of occurrence of risk factors and adherence to drug therapy in Yakuts who had Q-positive myocardial infarction]. Arhiv vnutrennei meditsiny, 2018, vol. 8, no. 4, pp. 291-299 (in Russian).

19. Myftiu S., Sulo E., Burazeri G. [et al.]. Clinical profile and management of patients with incident and recurrent acute myocardial infarction in Albania - a call for more focus on prevention strategies. Slovenian Journal of Public Health, 2017, vol. 56, no. 4, pp. 236-243.

20. Cao C-F., Li S-F., Chen H., Song J-X. Predictors and in-hospital prognosis of recurrent acute myocardial infarction. Journal of Geriatric Cardiology, 2016, vol. 13, no. 10, pp. 836-839.

21. Janzon M., Henriksson M., Hasvold P. [et al.]. Long-term resource use patterns and healthcare costs after myocardial infarction in a clinical practice setting: results from a contemporary na- 
tionwide registry study. European Heart Journal - Quality of Care and Clinical Outcomes, 2016, vol. 2, no. 4, pp. 291-298.

22. Scandanavian Simvastatin Survival Study Group. Randomised trial of cholesterol lowering in 4444 patients with coronary heart disease: the Scandinavian Simvastatin Survival Study (4S). Lancet, 1994, vol. 344, pp. 1383-1389.

23. Tonelli M., Moyé L. [et al.]. Effect of pravastatin on loss of renal function in people with moderate chronic renal insufficiency and cardiovascular disease. American Society of Nephrology, 2003, no. 14, pp. 1605-1613.

24. The long-term intervention with pravastatin in ischaemic disease (LIPID) study group. Prevention of cardiovascular events and death with prevastatinin patients with coronary heart disease and a broad range of initial cholesterol levels. The New England Journal of Medicine, 1998, no. 339, pp. 1349-1357.

25. ISIS-2 collaborative group. Randomised trial of intravenous streptokinase, oral aspirin, both, or neither among 17187 cases of suspected acute myocardial infarction. Lancet, 1988, vol. 332, no. 8607 , pp. 349-360.

26. Steinhubl S.R., Berger P.B., Mann J.T. [et al.]. Early and sustained dual oral antiplatelet therapy following percutaneous coronary intervention: a randomized controlled trial. The Journal of the American Medical Association, 2002, no. 288, pp. 2411-2420.

27. Berger J.S. Aspirin, clopidogrel, and ticagrelorin acute coronary syndromes. American Journal of Cardiology, 2013, no.112, pp. 737-745.

28. The acute infarction ramipril efficacy (AIRE) study investigators. Effect of ramipril on mortality and morbidity of survivors of acute myocardial infarction with clinical evidence of heart failure. Lancet, vol. 342, no. 8875, pp. 821-828.

29. HOPE (Heart Outcomes Prevention Evaluation) study investigators. Effects of an angiotensinconverting-enzyme inhibitor, ramipril, on cardiovascular events in high-risk patients. The New England Journal of Medicine, 2000, no. 342, pp. 145-153.

30. Teo K.K., Yusuf S. Furberg C.D. Effects of prophylactic antiarrhythmic drug therapy in acute myocardial infarction. An overview of results from randomized controlled trials. The Journal of the American Medical Association, 1993, no. 270, pp. 1589-1595.

31. Spertus J.A., Masoudi F.A., Reid K.J. [et al.]. Impact of medication therapy discontinuation on mortality after myocardial infarction. Archives of Internal Medicine, 2006, vol. 166, no.17, pp. 1842-1847.

32. Erlikh A.D. Dvoinaya antitrombotsitarnaya terapiya: neobkhodimost' priverzhennosti k lecheniyu i vozmozhnosti ee povysheniya [Dual antiplatelet therapy: the need for adherence to treatment and the possibility of its increase]. Aterotromboz, 2014, no. 2, pp. 25-33 (in Russian).

33. Thygesen K., Alpert J.S., Jaffe A.S. [et al.]. Third Universal Definition of Myocardial Infarction. Circulation, 2012, no. 126, pp. 2020-2035.

34. Nauchnaya platforma «profilakticheskaya sreda» [Scientific platform "Preventive environment], 2013. Available at: http://www.gnicpm.ru/UserFiles/prof_sreda_bazis_posl_variant.pdf (23.09.2018) (in Russian).

35. Dultsev K.N., Lapin O.M., Oschepkova M.A., Syromyatnikova L.I., Yunusov E.M., Chizhova A.A. Puti optimizatsii okazaniya meditsinskoi pomoshchi bol'nym s ostrym koronarnym sindromom (po dannym gospital'nogo etapa registra "Rekord-3") [Ways for optimization of rendering medical care to patients with acute coronary syndrome (by hospital register "Record-3" data)]. Sovremennye problemy nauki i obrazovaniya, 2015, no. 5, p. 196 (in Russian).

36. Lapin O.M. Sravnitel'nyi analiz rezhimov reperfuzionnoi terapii v lechenii bol'nykh infarktom miokarda s pod"emom segmenta ST v usloviyakh real'noi klinicheskoi praktiki [Comparative analysis of reperfusion therapy regimes in management of patients with ST segment elevation myocardial infarction in conditions of real clinical practice]. Sovremennye problemy nauki $i$ obrazovaniya, 2015, vol. 32, no. 5, pp. 37-43 (in Russian).

37. Ibanez B. [et al.]. 2017 ESC Guidelines for the management of acute myocardial infarction in patients presenting with ST-segment elevation. The Task Force for the management of acute 
myocardial infarction in patients presenting with ST-segment elevation of the European Society of Cardiology (ESC). European Heart Journal, 2017, no. 00, pp. 1-66.

38. Rymer J.A., Chen A.Y., Thomas L. [et al.]. Advanced practice provider versus physicianonly outpatient follow-up after acute myocardial infarction. Journal of the American Heart Association, 2018, vol. 7, no. 17.

39. Ciccone M.M., Aquilino A., Cortese F. [et al.]. Feasibility and effectiveness of a disease and care management model in the primary health care system for patients with heart failure and diabetes (Project Leonardo). Vascular health and risk management, 2010, no. 6, pp. 297-305.

40. Munkhaugen J., Peersen K., Sverre E. [et al.]. The follow-up after myocardial infarction is it good enough? Journal of the Norwegian Medical Association, 2018, vol. 138, no. 5.

41. Tung Y.C., Chang G.M., Chang H.Y., Yu T.H. Relationship between early physician follow-up and 30-day readmission after acute myocardial infarction and heart failure. PLoS One, 2017, vol. 12 , no. 1 .

Novikova I.A., Nekrutenko L.A., Lebedeva T.M., Kchlynova O.V., Shishkina E.A. PATIENT After cardiac infarction: risk factors that can cause new cardiovascular disasters. Health Risk Analysis, 2019, no. 1, pp. 135-143. DOI: 10.21668/health.risk/2019.1.15.eng

Received: 06.11.2018

Accepted: 24.02 .2019

Published: 30.03 .2019 
UDC 617.741-004.1-053.9

DOI: $10.21668 /$ health.risk/2019.1.16.eng

\title{
NK-CELLS THAT IDENTIFY GLYCOPATTERNS AND THEIR ANTI-TUMOR POTENTIAL AGAINST A BACKGROUND OF EPIDEMICALLY SIGNIFICANT VIRAL INFECTIONS
}

\author{
M.V. Lakhtin, V.M. Lakhtin, V.A. Aleshkin, S.S. Afanasiev \\ G.N. Gabrichevskiy's Moscow Scientific Research Institute for Epidemiology and Microbiology, 10 Admirala \\ Makarova Str., Moscow, 212125, Russian Federation
}

Risks related to tumors development against a background of viral infections as well as factors that determine such risks or reduce them have not been examined profoundly so far. Our research goal was to accomplish a scientific review of research on a potential possessed by populations of lectin NK-cells (natural killers) in a body; such populations can have variable sets of lectin and other functionally significant cell surface receptors against tumors in a situation when viruses, including epidemically significant ones, penetrate a body. It is shown that cofunctioning of various receptors and their ligands that redistribute cytokines (glycopattern-identifying lectin (basis) receptors, Ig-similar receptors, cytotoxic receptors, and other effector (adjusting) receptors) plays a significant role in intercellular communications and effects produced by NK-populations. NK-populations network is a promising resource for body protection and it should be taken into account when developing new anti-tumor and anti-viral preventive and medical strategies. When certain NK-populations with protective functions are absent in a body, it can be considered a new multi-factor risk of viral and oncologic diseases in an individual or a contingent living in a specific region. The reviewed data can be applied to develop new anti-tumor and anti-viral medications and vaccines as well as medical strategies. Probiotic lectins are promising ligands of intercellular communications associated with immune surveillance.

Key words: viral infections, tumors, multi-factor disease, risk factors, receptor lectins, NK-cells, anti-tumor strategies.

Over recent years researchers have detected high prevalence of oncologic morbidity and mortality all over the world. According to data provided by GLOBOCAN-2018 and IARC (International Agency for Research on Cancer) in 2018 Russia occupied the fifth place in the world as per number of death cases among oncologic patients. There are data on oncologic diseases in patients influenced by virus infec- tions and co-infections; for example, up to $2 \%$ neoplasms in the world are related to EpsteinBarr virus (EBV) [28]. Overall, risks related to tumor development against the background of occurring virus infections as well as factors that determine such risks or reduce them have not been studied to the extent they should be.

But at the same time researchers are paying greater attention to cell populations of in-

(c) Lakhtin M.V., Lakhtin V.M., Aleshkin V.A., Afanasiev S.S., 2019

Mikhail V. Lakhtin - Candidate of Biological Sciences, Senior Researcher (e-mail: info@gabrich.com; tel.: +7 (495) 708-02-62; ORCID: https://orcid.org/0000-0002-3311-0367).

Vladimir M. Lakhtin - Candidate of Biological Sciences, Chief Researcher (e-mail: lakhtinv@yandex.ru; tel: +7 (495) 708-02-62; ORCID: https://orcid.org/0000-0003-1737-0887).

Vladimir A. Aleshkin - Doctor of Biological Sciences, Professor, Honored Scientist, Research Suprevisor (e-mail: info@gabrich.com; tel: +7-985-998-01-22; ORCID: https://orcid.org/000-0001-6785-0016).

Stanislav S. Afanasiev - Doctor of Medical Sciences, Professor, Honored Scientist, Chief Researcher (e-mail: afanasievss409.4@bk.ru; tel: +7-903-667-20-68; ORCID: https://orcid.org/0000-0001-6497-1795). 
born immunity $[1,15,19,27]$. Thus, NK (natural killers)-cell populations (hereinafter called NK-populations) play a significant role as regards developing anti-body immunity in children $[6,26]$. Intercellular communications with NK-populations participation are given special attention due to their anti-microbe, anti-virus, and anti-tumor potential. Receptors that can recognize patterns play an important role in immunity; among them there are receptor lectins (RL) that recognize and bind carbohydrates and glycoconjugates (GC) [1, 2]. However, so far there has been little research on a role played by NK-populations in relation to tumor development against the background of occurring virus infections.

Our research goal was to perform a scientific review of research that focused on assessing anti-tumor potential possessed by lectin NK-populations with variable set of lectin and other functionally significant cell surface receptors in situations when viruses, including epidemically significant ones, penetrated a body.

Viruses and tumors considered in relation to them. Viruses that are examined in the aspect under consideration include the following: arenaviruses (lymphocytic choriomeningitis virus, LCMV), herpes viruses (cytomegalovirus, CMV), in relation to acute leukemia and B-cell lymphomas; co-infections with other viruses; Epstein-Barr virus, $\mathrm{EBV}$, in relation to mononucleosis, Burkitt lymphomas; vaginal herpes viruses [7, 28, 34]); papovaviruses (human papillomavirus, HPV, in relation to cervical cancer); pox viruses (cattle pox virus, mice pox virus, vaccinavirus or orthopoxvirus, VACV) [19, 27]; retroviruses (human immunodeficiency virus, HIV, including co-infection with CMV; in relation to lymphomas); flaviviruses (hepatitis-C virus, $\mathrm{HCV}$; in relation to hepatocellular carcinomas HCC); hepatitis-B virus [HBV] and hepatitis delta virus [HDV]) [25]; togaviruses (chikungunya virus; in relation to sarcomas) [24].
Variety of NK-populations typed by receptor lectins

RL subfamily of NKG2 type consists of type II transmembrane glycoproteins which are coded in the 12th human chromosome. CD94 and NKG2 genes are clustered in NK-gene complex (NKC) in the 12th chromosome (in 12p12-p13 chromosome gene cluster related to functioning of heterodimeric CD94NKG2-receptors). They code lectin outer domain and cytoplasmic domain to initiate further communications between NK-cells and some T-cells populations. Lectins from a subfamily that includes NGG2D activating receptors are expressed on NKcells, NK-T-cells (NKT), subpopulations of gamma-delta-T-cells, T-cells activated by CD8+ (which are in synergy with the human complement system [21]), certain selfreactive CD4+ T-cells [41]. Populations of myeloid cells, monocytes, and NK-cells regulated by MHC-class-I-molecules and cells initiate body responses against tumors and virus infections. NK-cells belonging to RL subfamily NKG2 are lectins and their derivatives within $\mathrm{NKG} 2 \mathrm{~A} / \mathrm{B} / \mathrm{C} / \mathrm{D} / \mathrm{E} / \mathrm{H}$ structure: $\mathrm{A} / \mathrm{B}, \mathrm{D}$ are inhibitors of some intercellular pathways (including those via ITIMmotives in RL that influence SHP1-Tyrphosphatase); C, F, E/H activate other intercellular pathways (including involvement of ITAM-bearing DAP12 and DAP10 adapter proteins, as well as signaling via metabolic ways that depend on protein-Tyr-kinase) [2, $11,12,15,27]$.

Lectin NK-populations variability occurs not only due to combinational co-expression of NKG2, KIR genes (killer Ig-like receptors), NKp genes (NCR or natural cytotoxic receptors) and CD genes on cells but also due to varying phenotypes of interacting molecules (including those which are part of di- and oligomeric homo-and hetero-structures similar to CD94NKG, or tetrameric HLA-E) and genetic RL variants (multi-allele ones belonging to NKG2C1/2/3 type; NKG2E phenotype as two alternative splicing forms $\mathrm{NKG} 2 \mathrm{E}$ and 
NKG2H [27=24]). They gradually become apparent under post-genome changes when genetic chimeric products are constructed (shortened ones [belonging to $\mathrm{NKG} 2 \mathrm{Ce}$ type C-end shortened form - NKG2C3]; outer, transmembrane, and cytoplasmic / intracellular $\mathrm{RL}$ domains [belonging to $\mathrm{NKG} 2 \mathrm{~F}$ type that is expressed as an intracellular form only], products of genetic maps obtained for CD94NKG2 contacts, and others) [12, 27, 39, 40].

Ontogenesis of NK-cells, in its turn, makes its contribution into NK-populations variety. NK-cells usually develop from a common lymphoid predecessor and undergo several stages in the process. CD122 (betachain of IL15 receptor) occurrence means that a predecessor has started to differentiate and NK-cells will start to form soon. When NK-cells are developing, one can observe progressive exposure of CD161; CD56, CD94/NKG2A， NKp46 (NCR1， CD335), NKp44 (NCR2, CD336); NKG2D (exposed on all the human NK-cells and participates in Cross-Talk between lymphoid and myeloid cells of anti-viral immunity [36]); and, finally, CD16 and KIR [24]. Stages 4 and 5 are the most significant among all the stages in NK-cells development when it comes to peripheral blood cells; they are characterized with occurrence of CD56bright and CD56dim, respectively. CD56bright in an NK-population is characterized with high expression of CD94. CD56dim of an NK-cell correspond to KIR- and CD16-populaiton as the most mature ones that transform into cytotoxic cells which, in their turn, become maximum and ultimately differentiated and express CD57.

NKG2-receptors can also be met among greatly varying T-lymphocytes subpopulations and it implies there is coherent cofunctioning of NK subpopulations and cytotoxic T-lymphocytes subpopulations [12]. $\mathrm{NKG} 2 \mathrm{H}$ is expressed in a small number of monocytes in peripheral blood but it is to a greater extent detected in T-cells stimulated by anti-CD3-antibodies [12].
Adaptive RL expression and distribution of RL types between cells populations is influenced by an overall state of a body (heredity, age, sex, immune system state, other factors), pathologies, types of viruses and tumors $[8,10,35]$.

Predominantly, NKG2 and KIR and their ligands participate in HLA-class-I modulation [27, 41]. Signals that arise due to interaction between $\mathrm{CD} 94^{+} \mathrm{NKG}^{+} / \mathrm{KIR}^{+}$receptors and MHC-class-I-glycoproteins as a response to occurrence of abnormal pattern ligands redistribute NK-populations activities. Mobile memory of NK-cells is implemented due to genetic predetermination. Genome of a human body is characterized with moderate variety of NKG2 genes against elevated varying in KIR genes [39]. NKG2D gene polymorphism supports modulation of NK-cellular cytotoxicity. It is significant, for example, in relation to a body being susceptible to HPV-induced cancer [13]. Limited immunologic functions performed by MHCE/NKG2 system develop in a human body when functions of MHC-I/KIR system expand [39]. Expression of HLA-class-I drops drastically with KIR participation in cells infected with viruses, while expression of HLA-E (is usually detected on tumor cells; is a section where RL are bound) is more stable and is supported by activating NKG2-receptors $[10,12,27,39]$.

Pools of lectin NK-populations differ significantly as regards their functions as they are aimed at different virus and cellular targets in such a way that there is correspondence of NK-populations (to relevant sets of lectin and other receptors) within a species. One can observe interspecific correspondence of interactions performed by mice lectin Ly49H+ NK-populations against mice CMV [27], or lectin NK-populations in a human body or a macaque, depending on HIV1 or SIV, respectively [39]. NK-cells differentiation is age-dependent [24]. Expression of CD94+NKG2C-/NKG2A+, NKG2D, NKp30(NCR3, CD337) and NKp46 on NK- 
cells falls with age $[32,35]$. Discrepancies in NK-populations phenotypes occur in relation to a sex [32]. Systems of RL and NK-cells or other myeloid cells (monocytes and macrophages) that expose them vary depending on age $[6,8,24,27,32,35]$. NK-populations are determined not only by sets of lectin, Iglike, cytotoxic, and other receptor markers (NKG2, KIR, NKp, CD), but also ratios of their expressions quantities, stages in their development, their maturity (how differentiated they are and how apparent their cytotoxicity is).

$C D$ - indicators of NK-populations

CD co-function with RL both in individual NK-cells and within co-functioning NKpopulations. RL together with $\mathrm{CD}$ are identified as combined markers of cells populations $[1,2]$. Several key CD are given below.

*CD3 and CD20 (T- and B-cells markers) are absent in NK-cells.

*CD11b-CD27+; CD11b-CD27+ are markers that show a weakened differentiation (immaturity) of NK-cells [19].

*CD56brightNKG2C+-population that is able to expand in CMV-individuals; cells show inhibiting Ig-like RL (KIR and leukocyte Iglike receptor [LILRB1]), specific to HLA-classI-molecules against low levels of activating receptors NKp46 and NKp30 [27]; CD56bright is a marker of immature NK-cells (more than 90\% NK-cells which are able to adapt further and turn into mature ones [11]).

*CD56dim/CD57+NKG2C+-populations are detected in patients with lymphoma [11, 29]; elevated frequency of CD56dim and CD57+ in NK-cells were detected in men [32]; CD57 is a marker that shows terminal differentiation of NK-cells [31]; CD56dim-populations express either CD94NKG2A+ or coexpress CD94NKG2C+ and KIR+ [11].

*CD69 is a marker showing activation of NK-cells differentiation [19].

*CD94+NKG2+ are markers with synergetic functioning of $\mathrm{CD} 94 / \mathrm{NKG} 2 \mathrm{~A}$ and CD94/NKG2C [11, 24, 27], CD94 is a significant factor in protection against viruses [11, 27, 31, 39].
*CD94+NKG2A+, NKG2D+ and NKp46+ function in synergy $[24,36]$.

*CD158a, CD158b are markers showing recovery and strengthening of NK-population that produces perforin and granzymes [23].

\section{Cytokines and NK-populations}

Anti-tumor effects produced by inborn immunity become apparent via modulating production of cytokines sets and, as a result, factors that are cytotoxic in relation to tumor cells are produced (or delivered) there where a tumor is localized in a body. Anti-tumor NK-production of interferon (IFN-gamma) $[6,15,17,20,22,23,24,29]$ and tumor necrosis factor (TNF) is induced [15, 24, 29]. NK-cells are controlled with interleukins (IL-2, 5, 12, 13, 15, 18) [15, 24, 30] and with participation of colony stimulating factor (CSF1) [37]. IL15 is a key interleukin here and crucial for NK-cells maturation, differentiation and survival; it potentiates cytotoxicity of NKG2-populations [6, 24, 30]. Suppression of NK-cells functions is influenced by transforming growth factor (TGF- beta1) of tumor nature $[8,40]$. CSF1 induces occurrence of RAE-1-delta on macrophages that infiltrate a tumor, and RAE-1-delta is a specific ligand that regulates NKG2D-populations [37].

NK-cells ability to produce cytokines is associated with specific stages in NK-cells development. CD56bright NK-population efficiently produces cytokines as a response to stimuli, however, CD56dim NK-cells can be more efficient in producing cytokines [24]. TNF-alpha is produced by NK-cells in the process of their differentiation, and only later, when competing with CD56 expression and against a decrease in IL5 and IL13 production, NK-populations become able to produce IFNgamma [24].

\section{Cytotoxic factors of NK-populations}

As phenotypes are transformed into relevant cytotoxic cells populations, granzymes A, $\mathrm{B}$, and $\mathrm{K}$, perforin, and other anti-tumor agents are released in the process $[6,19,23]$. These factors are in systemic contrast with scattered 
tumor factors (lactate dehydrogenase, TGF-beta, CSF1, some others) [8, 37, 40].

NK-populations with anti-tumor / anti-viral activities (the order: NK-populations; tumor targets linked to viruses; effects produced by NKpopulations)

*NKG2A+CD56bright; "humanized" mice B-cell lymphoma; IFN-gamma release by the population, cooperation with NKp44-receptors in order to inhibit B-cell transformation linked to EBV [22].

*NKG2A+; when VACV is present, populations are expressed more strongly [19].

*NKG2A+KIR-; set a limit to lytic EBVreplication [28].

*NKG2A+ against EBV [11].

*NKG2A+KIR+, NKG2A+NKG2C-KIR-, $\mathrm{NKG} 2 \mathrm{C}+\mathrm{KIR}+$; $\mathrm{CMV}$-infected derivatives of human monocytes; KIR+NKG2C+ doesn't influence a response by KIR-NKG2C-

*NKG2C+; U266 (cells of human multiple myeloma) from CMV-seropositive donors, K562 (leukemic human cells); expansion of the population in a body is stimulated $[6,10]$, occurrence of latent CMV in healthy donors becomes apparent via stronger NKcytotoxicity [6].

*NKG2C+CD57+; lymphomas; the population expands as a response to CMV [31].

*NKG2C+ (predominantly); mice lymphomas; action performed by the population and caused by CMV occurrence takes place after allogenic transplantation [30].

* NKG2C+; anti-tumor application of ligands for $\mathrm{NKG} 2 \mathrm{C}$ [33].

* NKG2C+; CMV-infected endothelial cells of the aorta; character of population modulation depends on a type of CMV-infected cells [10].

*NKG2C+NKG2A-; 221.AEH (transfected HLA-E+-cells of human lymphoma); NK-cytotoxicity is three times higher than in non-transfected ones, 221.АЕН и ИЛ15 make for expansion of the population in a body $[6,33]$.

*NKG2C+CD94+; Burkitt lymphoma; the population participates in protection of cooperation together with gamma-delta-Tcells [11].

*NKG2C+NKG2A-KIR+; co-infection caused by EBV and CMV; stimulation of NKpopulation [11].

*NKG2C+CD56dim/CD57+ (mature and cytotoxic); leukemic T-cell lymphoma; after blood was transplanted, and CMV reactivated, 2 years later the population increases up to $33 \%$ of all lymphocytes; produces TNF-alpha and IFN-gamma against cells of leukemic T-cell lymphoma [29].

*NKG2D+; patients with $\mathrm{HCV}$-induced HCC; increased NKG2D expression on monocytes together with anti-tumor effects produced with NKG2D-ligands [8].

*NKG2D+; patients with anogenital cancer (HPV is detected); NKG2D-determined cytotoxicity is enhanced, susceptibility to cancer falls [13].

*NKG2D + (NK92: chimeric TN-cells); xenografts of $\mathrm{HCV}$-induced HCC; the population is with expression of NKG2D, produces IFN-gamma, and is efficient against TGF-betaproducing tumor cells [40].

*NKG2D-4-1BB-CD3z-CAR+-redirected T-cells CD45RA- of the memory (CD45RANKG2D-CAR+) were cytotoxic for osteosarcomic cells $531 \mathrm{MII}$ which expressed ligands to NKG2D (lysed them) in vitro and in mice bodies [16].

As we can see from all the data given above, multifunctional NKG2A+-, NKG2C+и NKG2D+-populations with RL from NKG2subfamily have been examined most profoundly. They act as glycopatterns identifiers, inducers (in modulating intercellular communications pathways), and basic ones (to increase selectivity of an effect, additional superstructural / adjusting / tuning receptors are required). Some other combinations of receptors in NK-populations are also known [11, 12, $35,39]$. So, a set of NK-populations acts as "network-within-network".

Strategies of NK-population use

Protective NK-populations are synergetic with other cellular (CD8+ T-cells, blood cells, 
macrophages, and dendritic cells) and complicated immunity systems. A significant contribution is made by accumulation of anti-tumor / antiviral circulating monocytes in a body and their consequent transportation to a tumor; infiltration expansion by cells of network NKcompartment into microenvironment around a tumor is also very important.

Multi-functionality of genetic inclusions in the human genome has not been studied enough as it is the case with apparent endogenous retrovirus-like inclusions which account for about $8 \%$ repeats in the human genome [18]. Such inclusions are co-localized with protection genes (lectin-like components in $\mathrm{C} 4 \mathrm{~B}$ и $\mathrm{C} 4 \mathrm{~A}$ [3] complement) and it should provide their co-functioning in protective activities [18]). Such protection could possibly result in initiation and longer persistence of protector NK-populations in a body that prevent viruses from expansion. There are a lot of example cases when seropositive people (with latent CMV-infection) are healthy (not patients). Besides, more than $90 \%$ adult population (not necessarily patients) "undergo" EBV occurrence in their bodies without any symptoms [7]. Therefore, an adaptive set of preventive and therapeutic NK-populations that exists in a human body offers a lot of prospects for their application against active epidemically significant viral infections as well as against tumors initiation and development.

NKG2-receptors and their ligands create a metabolic supervisory communication channel between lymphoid and myeloid immunity cells; they co-stimulate cytotoxic responses via NKp46-receptors of NK-cells and cytotoxic receptors of T-cells; induce sets of antitumor and antiviral cytokines; support proliferation and survival of effector cells [36]. It can be applied to work out strategies aimed at fighting against tumors including those incorporating antiviral effects. As a result, essential NK-cell types and populations grow in number and their expansion inside a tumor takes place $[11,14$,
15, 27]. Effects produced by NK-populations are coordinated with the complement system [21].

Below there are some promising ways how to apply NK-populations.

*NKG2+-populations for creating new antiviral strategies (as it is the case with HIV1) [31, 39].

*Targeted application of NKG2D+-populations against tumors with the use of NKG2D-receptors belonging to supervisory effector NK-cells which act in a stand-by mode and monitor occurrence / initiation of tumor ligands on stress cells as such ligands are tumor precursors [8, 14]. And here cells that express NKG2D-ligands (as it happens in case of super-expression of sets in stress cells insides the intestines) are recognized and eliminated by supervisory cells and it is aimed at preventing carcinogenesis, for example, rectum cancer [14].

*CD56brightNKG2A+-population applied in adjusting EBV-associated lymphomas [22].

*Treatment provided for patients with acute lymphoblastic leukemia via recovery and growth of NK-populations with expression of CD158a, CD158b, perforin, and granzyme K among NK-populations with different granzymes types expression [23].

*Transplantation of blood with therapeutic NK-populations against hematologic tumors [30].

*Targeted regulation of interactions with adapter proteins DAP12 and DAP10 that involves NK-populations [12, 27, 33].

*Application of NK-populations based on orthologs and paralogs of mammals RL for treatment [39].

*Application of antitumor genetically modified chimeric NK-populations of CAR [chimeric antigen receptor]-T-cells (for example, with expressed chimeric receptor TN that includes outer and transmembrane domains of TGF-beta-type-II-receptor and intracellular domain of NK-cellular activating receptor NKG2D [40]). 
There are also promising preventive and therapeutic possibilities to prevent dysbiotic states of mucosal biotopes in open cavities from transforming into tumor ones, including participation of NKG2D/ NKG2D-ligands NK-populations system that activates DDRpathway (DNA damage response) as well as effects produced by probiotic lectins with cytokine-like activities [5, 13, 14]. Since probiotic lectins, in case of microbe-virus dysbiosis, can be selectively aimed at opportunistic pathogens (including those changed under inflammation) and can also act as probiotics when probiotic cellular microflora is absent in mucosal biotopes against HPV occurrence in them which is a potential inducer of vaginal cancer, one can predict that there can be anti-cancer / antiviral synergy of probiotic lectins and NKG2D-caused cytotoxicity that reduces susceptibility to cancer $[5,13,38]$.

Conclusion. Influence exerted on NKpopulations networks by lectin receptors (that initiate cascades of identifying communications), Ig-like, cytotoxic, CD- and some other receptors as well as their ligands (including glycoconjugates that modulate RL) is very promising for creating and regulating long-term antitumor and antiviral processes in a body. When key oriented NK-populations with protective functions are absent in a body, it can be considered an additional multi-factor risk criterion that possibly indicates elevated risks of viral and oncologic diseases in an individual or population living on a specific territory or in a specific region. It is advisable to diagnose which NKpopulations are present in a body to strategically assess antitumor and antiviral state of a donor and a patient, to work out optimized personified treatment, as well as to construct preventive-therapeutic cellular-cytokine combinations with participation of chimeric gene-modified NK-populations belonging to CAR-T type, for example, to perform highly efficient targeted/selective CAR-T anticancer therapy $[9,16,40]$. The given data can be applied to develop new antitumor and antiviral medications, vaccines, and medical strategies. Probiotic lectins are promising ligands participating in intercellular communications in the process of immune surveillance $[3,4]$.

Funding. The research was not granted any sponsor support.

Conflict of interests. The authors state there is no any conflict of interests.

\section{References}

1. Lakhtin M.V., Lakhtin V.M., Aleshkin V.A. Afanas'ev C.S. Lektinovye retseptory v kommunikatsiyakh. News of science and education, 2018, vol. 2, no. 3, pp. 76-98 (in Russian).

2. Lakhtin M.V., Lakhtin V.M., Aleshkin V.A., Afanas'ev M.S. Afanas'ev S.S. Lektiny v antirakovykh strategiyakh. Acta Biomedica Scientifica, 2018, vol. 3, no. 4, pp. 69-77 (in Russian).

3. Lakhtin M.V., Lakhtin V.M., Afanas'ev S.S., Aleshkin V.A. Novye glikokon"yugatyraspoznayushchie sistemy $\mathrm{v}$ prognozirovanii antiinfektsionnogo interaktoma cheloveka. Zdorov'e $i$ obrazovanie v XXI veke. Seriya Meditsina, 2015, vol. 17, no. 4, pp. 378-383 (in Russian).

4. Lakhtin M.V., Lakhtin V.M., Afanas'ev S.S. [et al.]. Nadzor za mikrobiotsenozami: novye podkhody. Obespechenie epidemiologicheskogo blagopoluchiya: vyzovy i resheniya: materialy XI s"ezda Vserosciiskogo nauchno-prakticheskogo obshchestva epidemiologov, mikrobiologov i parazitologov. Moscow, 2017. In: A. Yu. Popova ed. Sankt-Peterburg, FBUN NII epidemiologii i mikrobiologii imeni Pastera Publ., 2017, 436 p. (in Russian).

5. Lakhtin M.V., Lakhtin V.M., Afanas'ev S.S., Bairakova A.L., Aleshkin V.A., Afanas'ev M.S. Kandidnye markery boleznei urogenital'nykh biotopov: reaktivnost' k lektinam probiotikov. Acta Biomedica Scientifica, 2018, vol. 3, no. 1, pp. 49-53 (in Russian). 
6. Bigley A.B., Rezvani K., Shah N., Sekine T., Balneger N., Pistillo M. [et al.]. Latent cytomegalovirus infection enhances anti-tumour cytotoxicity through accumulation of $\mathrm{NKG}^{+} \mathrm{C}^{+} \mathrm{NK}$ cells in healthy humans. Clinical \& Experimental Immunology, 2016, vol. 185, no. 2, pp. 239-251.

7. Chijioke O., Landtwing V., Münz C. NK cell influence on the outcome of primary EpsteinBarr virus infection. Frontiers Immunology, 2016, vol.7, no 323. DOI: 10.3389/fimmu.2016.00323

8. Crane C.A., Austgen K., Haberthur K., Hofmann C., Moyes K.W, Avanesyan L. Immune evasion mediated by tumor-derived lactate dehydrogenase induction of NKG2D ligands on myeloid cells in glioblastoma patients [et al.]. Proceedings of the National Academy of Sciences of the United States of America, 2014, vol. 111, no 35, pp. 12823-12828.

9. Demoulin B., Cook W.J., Murad J., Graber D.J., Sentman M.-L., Lonez C. Exploiting natural killer group 2D receptors for CAR T-cell therapy [et al.]. Future Oncology, 2017, vol. 13, no. 18, pp. 1593-1605.

10. Djaoud Z., Riou R., Gavlovsky P.J., Mehlal S., Bressollette C., Gérard N. [et al.]. Cytomegalovirus-infected primary endothelial cells trigger $\mathrm{NKG}_{2} \mathrm{C}^{+}$natural killer cells. Journal of Innate Immunity, 2016, vol. 8, no. 4, pp. 374-385.

11. Djaoud Z., Guethlein L.A., Horowitz A., Azzi T., Nemat-Gorgani N., Olive D., Nadal D. [et al.]. Two alternate strategies for innate immunity to Epstein-Barr virus: One using NK cells and the other NK cells and gamma-delta T cells. The Journal of Experimental Medicine, 2017, vol. 214, no. 6, pp. 1827-1841.

12. Dukovska D., Fernández-Soto D., Valés-Gómez M., Reyburn H.T. NKG2H-expressing T cells negatively regulate immune responses. Frontiers in Immunology, 2018, vol. 9, no. 390. DOI: 10.3389/fimmu.2018.00390

13. Espinoza J.L., Nguyen V.H., Ichimura H., Pham T.T., Nguyen C.H., Pham T.V. [et al.]. A functional polymorphism in the NKG2D gene modulates NK-cell cytotoxicity and is associated with susceptibility to Human Papilloma Virus-related cancers. Scientific Reports, 2016, vol. 6, no. 39231. DOI: 10.1038/srep39231

14. Espinoza J.L., Minami M. Sensing bacterial-induced DNA damaging effects via natural killer group 2 member D immune receptor: From dysbiosis to autoimmunity and carcinogenesis. Frontiers in Immunology, 2018, vol. 9, no. 52. DOI: 10.3389/fimmu.2018.00052

15. Fehniger T.A., Cooper M.A. Harnessing NK cell memory for cancer immunotherapy. Trends in Immunology, 2016, vol. 37, no. 12, pp. 877-888.

16. Fernandez L., Metais J.-Y., Escudero A., Vela M., Valentín J., Vallcorba I. [et al.]. Memory T Cells Expressing an NKG2D-CAR Efficiently Target Osteosarcoma Cells. Clinical Cancer Research, 2017, vol. 23, no. 19, pp. 5824-5835. DOI: 10.1158/1078-0432.CCR-17-0075

17. Georgountzou A., Papadopoulos N.G. Postnatal innate immune development: From birth to adulthood. Frontiers in Immunology, 2017, vol. 8, no. 957. DOI: 10.3389/fimmu.2017.00957

18. Grandi N., Cadeddu M., Pisano M.P., Esposito F., Blomberg J., Tramontano E. Identification of a novel HERV-K(HML10): Comprehensive characterization and comparative analysis in non-human primates provide insights about HML10 proviruses structure and diffusion. Mobile DNA, 2017, vol. 8, no. 15. DOI: 10.1186/s13100-017-0099-7

19. Hatfield S.D., Daniels K.A., O'Donnell C.L., Waggoner S.N., Welsh R.M.Weak vaccinia virus-induced NK cell regulation of CD4 $\mathrm{T}$ cells is associated with reduced NK cell differentiation and cytolytic activity. Virology, 2018, vol. 519, pp. 131-144.

20. Heiberg I.L., Pallett L.J., Winther T.N., Høgh B., Maini M.K., Peppa D. Defective natural killer cell anti-viral capacity in paediatric HBV infection. Clinical \& Experimental Immunology, 2015, vol. 179, no. 3, pp. 466-476.

21. Janelle V., Langlois M.P., Tarrab E., Lapierre P., Poliquin L., Lamarre A. Transient complement inhibition promotes a tumor-specific immune response through the implication of natural killer cells. Cancer Immunology Research, 2014, vol. 2, no. 3, pp. 200-206.

22. Jud A., Kotur M., Berger C., Gysin C., Nadal D., Lünemann A. Tonsillar CD56 ${ }^{\text {bright }}$ $\mathrm{NKG}_{2} \mathrm{~A}^{+} \mathrm{NK}$ cells restrict primary Epstein-Barr virus infection in B cells via IFN-gamma. Oncotarget, 2017, vol. 8, no. 4, pp. 6130-6141. 
23. Koltan S., Debski R., Koltan A., Grzesk E., Tejza B., Eljaszewicz A. [et al.]. Phenotype of NK cells determined on the basis of selected immunological parameters in children treated due to acute lymphoblastic leukemia. Medicine (Baltimore), 2015, vol. 94, no. 52, 2369 p. DOI: 10.1097/MD.0000000000002369

24. Mahapatra S., Mace E.M., Minard C.G., Forbes L.R., Vargas-Hernandez A., Duryea T.K. [et al.]. High-resolution phenotyping identifies NK cell subsets that distinguish healthy children from adults. Public Library of Science, 2017, vol. 12, no. 8, pp. e0181134. DOI: 10.1371/journal.pone.0181134

25. Malone D.F.G., Lunemann S., Hengst J., Ljunggren H.G., Manns M.P., Sandberg J.K. [et al.]. Cytomegalovirus-driven adaptive-like natural killer cell expansions are unaffected by concurrent chronic hepatitis virus infections. Frontiers in Immunology, 2017, vol. 8, no. 525. DOI: 10.3389/fimmu.2017.00525

26. Martinez D.R., Permar S.R., Fouda G.G. Contrasting adult and infant immune responses to HIV infection and vaccination. Clinical and Vaccine Immunology, 2015, vol. 23, no. 2, pp. 84-94.

27. Muntasell A., Vilches C., Angulo A., López-Botet M. Adaptive reconfiguration of the human NK-cell compartment in response to cytomegalovirus: A different perspective of the hostpathogen interaction. European Journal of Immunology, 2013, vol. 43, no. 5, pp. 1133-1141.

28. Münz C. Epstein-Barr virus-specific immune control by innate lymphocytes. Frontiers in Immunology, 2017, vol. 8, no. 1658. DOI: 10.3389/fimmu.2017.01658

29. Muta T., Yoshihiro T., Jinnouchi F., Aoki K., Kochi Y., Shima T. [et al.]. Expansion of NKG2C-expressing natural killer cells after umbilical cord blood transplantation in a patient with peripheral T-cell lymphoma with cytotoxic molecules. Internal Medicine, 2018, vol. 57, no. 6, pp. 861-866.

30. Peled J.U., Jenq R.R. Not just leukemia: CMV may protect against lymphoma recurrence after allogeneic transplant. Leukemia \& Lymphoma, 2017, vol. 58, no. 4, pp. 759-761.

31. Peppa D. Natural killer cells in human immunodeficiency virus-1 infection: spotlight on the impact of human cytomegalovirus. Frontiers in Immunology, 2017, vol. 8, no. 1322. DOI: 10.3389/fimmu.2017.01322

32. Phan M.T., Chun S., Kim S.H., Ali A.K., Lee S.H., Kim S. [et al.]. Natural killer cell subsets and receptor expression in peripheral blood mononuclear cells of a healthy Korean population: Reference range, influence of age and sex, and correlation between NK cell receptors and cytotoxicity. Human Immunology, 2017, vol. 78, no. 2, pp. 103-112.

33. Pupuleku A., Costa-García M., Farré D., Hengel H., Angulo A., Muntasell A. [et al.]. Elusive role of the CD94/NKG2C NK cell receptor in the response to cytomegalovirus: Novel experimental observations in a reporter cell system. Frontiers in Immunology, 2017, vol. 8, no. 1317. DOI: 10.3389/fimmu.2017.01317

34. Sehrawat S., Kumar D., Rouse B.T. Herpesviruses: Harmonious Pathogens but Relevant Cofactors in Other Diseases? Frontiers in Cellular and Infection Microbiology, 2018, vol. 8, no. 177. DOI: $10.3389 /$ fcimb.2018.00177

35. Sundström Y., Nilsson C., Lilja G., Kärre K., Troye-Blomberg M., Berg L. The expression of human natural killer cell receptors in early life. Scandinavian Journal of Immunology, 2007, vol. 66 , no. 2-3, pp. 335-344.

36. Stojanovic A., Correia M.P., Cerwenka A. The NKG2D/NKG2DL axis in the crosstalk between lymphoid and myeloid cells in health and disease. Frontiers in Immunology, 2018, vol. 9, no. 827 . DOI: $10.3389 /$ fimmu.2018.00827

37. Thompson T.W., Jackson B.T., Li P.J., Wang J., Kim A.B., Huang K.T.H. [et al.]. Tumor-derived CSF-1 induces the NKG2D ligand RAE-1-delta on tumor-infiltrating macrophages. Elife, 2018, vol. 7, no. e32919. DOI: 10.7554/eLife.32919

38. Uppendahl L.D., Dahl C.M., Miller J.S., Felices M., Geller M.A. Natural killer cell-based immunotherapy in gynecologic malignancy: A review. Frontiers in Immunology, 2018, vol. 8, № 1825. DOI: 10.3389/fimmu.2017.01825

39. Walter L., Petersen B. Diversification of both KIR and NKG2 natural killer cell receptor genes in macaques - implications for highly complex MHC-dependent regulation of natural killer cells. Immunology, 2017, vol. 150, № 2, pp. 139-145. 
40. Wang Z., Guo L., Song Y., Zhang Y., Lin D., Hu B. [et al.]. Augmented anti-tumor activity of NK-92 cells expressing chimeric receptors of TGF-beta-R II and NKG2D. Cancer Immunology, Immunotherapy, 2017, vol. 66, no. 4, pp. 537-548.

41. Zingoni A., Molfetta R., Fionda C., Soriani A., Paolini R., Cippitelli M. [et al.]. NKG2D and its ligands: "One for all, all for one". Frontiers in Immunology, 2018, vol. 9, no. 476. DOI: 10.3389/fimmu.2018.00476

Lakhtin M.V., Lakhtin V.M., Aleshkin V.A., Afanasiev S.S. NK-cells that identify glycopatterns and their anti-tumor potential against a background of epidemically significant viral infections. Health Risk Analysis, 2019, no. 1, pp. 144-153. DOI: 10.21668/health.risk/2019.1.16.eng

Received: 18.10 .2018

Accepted: 26.01.2019

Published: 30.03.2019 
UDC 613.2

DOI: 10.21668/health.risk/2019.1.17.eng

\title{
TECHNIQUES FOR DETERMINING PHTHALATES IN FOOD PRODUCTS AIMEd FOR INFANTS' NUTRITION: An OVERVIEW
}

\author{
T.S. Ulanova, T.D. Karnazhitskaya, A.S. Zorina \\ Federal Scientific Center for Medical and Preventive Health Risk Management Technologies, 82 Monastyrskaya Str., \\ Perm, 614045, Russian Federation
}

Phthalates (esters of phthalic acid) are widely used as plasticizers in polymer materials production and it has resulted in substantial contamination with phthalates as they occur in environmental objects, food products, drinking waters, and human biological media. Toxic effects produced by phthalates lead to functional disorders in the endocrine system and synthesis of insulin, phthalates have reproductive toxicity, they cause allergenic reactions and bronchial asthma in children as well as some other diseases. Food products are a primary source of influences exerted by phthalates on population health, first of all, children. To assess risks related to adverse effects by phthalates on children, it is necessary to obtain data on concentrations of these substances in food products aimed for children nutrition. In order to work out a highly sensitive and selective technique for determining phthalates in children nutrition, the authors performed an overview of scientific and technical literature that focused on techniques for determining phthalates in products for infant nutrition (milk mixtures, milk cereals, and canned meat). It was detected that gas and liquid chromatography together with mass spectrometry were widely applied to analyze phthalates in children nutrition; several techniques were applied for samples preparations to exert direct influence on measurements sensitivity and precision. It is still vital to determine how to efficiently extract phthalates with conventional and up-to-date extraction techniques and how to purify them from complicated food matrixes, first of all, milk and vegetable fats that can be found in products aimed for children nutrition. There is a still a problem related to secondary contamination of samples with phthalates due to their occurrence in the air inside laboratories, reagents, solvents, etc., and it needs to be solved. Basing on the analysis of all the reviewed data, we can conclude that it is necessary to work out highly sensitive, selective, and highly precise techniques for determining phthalates in products aimed for children nutrition with new methodical tools for samples preparation taking into account a matrix effect which is specific for certain products as well as risks related to secondary contamination of samples in the process of their preparation and analysis.

Key words: phthalates, food products, milk mixtures, canned meat, gas and liquid chromatography, massspectrometry, samples preparation.

Phthalates (esters derived from o-phthalic acid) are widely spread contaminants; they are identified as endocrine-disrupting chemicals. Phthalates are applied as plasticizers for polymer materials based on polyvinyl chloride (PVC), polystyrene, and rubbers; they products with mass fracture of polymers in their structure being equal to $15-40 \%$ more flexible and durable. There are no any chemical bonds between phthalates and polymers and the former are washed out of plastic products during their use. People, especially younger children, are exposed to phthalates primarily due to their occurrence in food products $[1,2,3]$.

Exposure to phthalates results in hormonal and metabolic disorders, development defects, deviations in the reproductive system functioning, and other diseases [4, 5]. Bis(2-ethylhexyl phthalate) is considered to be "a possible human carcinogen" by the International Agency for Research on Cancer [5].

Over the last decades there has been extensive research on assessing health risks caused by exposure to phthalates; fixing permissible daily consumption of individual

(C) Ulanova T.S., Karnazhitskaya T.D., Zorina A.S., 2019

Tat'yana S. Ulanova - Doctor of Biological Sciences, Professor, head of Chemical and Analytical Research Department (e-mail: ulanova@fcrisk.ru; tel.: +7 (342) 233-10-37).

Tatyana D. Karnazhitskaya - Candidate of Biological Sciences, Head of the Laboratory for Liquid Chromatography Techniques (e-mail: tdkarn@fcrisk.ru; tel.: +7 (342) 233-10-37; ORCID: https://orcid.org/0000-0001-6768-0045).

Anastasia S. Zorina - chemist at the Laboratory for the Liquid Chromatography Techniques (e-mail: root@fcrisk.ru; ORCID: https://orcid.org/0000-0002-4276-9921). 
phthalates; determining phthalates concentrations in food products, drinking water, the atmospheric air and air inside buildings, and other media. Speaking about impacts exerted by phthalates on children's health, especially infants and children younger than 3 , we should mention one of the most vital lines of research, namely monitoring over contamination of milk and milk products (powder-like and liquid milk mixtures and milk cereals) as they are the only nutrition suitable for infant children and children younger than 3 .

The paper dwells on surveying various techniques for determining phthalates in food products for younger children's nutrition (milk mixtures, milk cereals, and canned meat). Primarily our attention is paid to techniques applied to prepare samples for instrumental analysis and to reduce risks of secondary contamination with phthalates which can happen to analyzed samples.

Phthalates were first determined in food products more than 50 years ago $[6,7]$. As it was not the case with other chemical contaminants, data on phthalates concentrations in food products were rather limited due to problems related to methodical support and high phthalates concentrations in field blanks; the latter was caused by laboratory environment, reagents, and materials being contaminated with these chemicals.

According to the Sanitary-epidemiologic rules 2.3.2.1940-05 food products made for younger children's nutrition are food products that can be consumed by children from their birth to 3 years as their structure and properties correspond to physiological peculiarities that children have at this age [8]. Food products for younger children are substitutes for breast milk made from animal milk or vegetable raw materials (cow's milk, soya proteins, etc.) as well as food products introduced into children's daily ration during their first year of life in addition to breast milk or its substitutes; such products are made of animal and/or vegetable raw materials and they can be either purees or dried mixtures.

In spite of multiple works focusing on methodical approaches to determining phtha- lates in food products from various categories, there are very few data on how to analyze them in food products for younger children; basically any data we could find concern phthalates occurrence in various food products made for common nutrition. Thus, scientific and technical information that can be found on SciensDirect web-site reveals that only 356 works out of total 7,343 containing such key words as "determination of phthalates" and published over the last 5 years dealt with analyzing phthalates in children nutrition [9].

Over the last years such techniques as liquid and gas chromatography together with mass spectrometry have been applied to quantitatively determine phthalates mixture in food products, including those aimed for children's nutrition; they allow to successfully resolve issues related to measuring techniques being sensitive and selective. Apart from mass spectrometric detectors, gas chromatography is accomplished with flame ionizing detectors and electronic capture [10]; highperformance liquid chromatography is applied to analyze phthalates with ultrasound and fluorimetric detectors [10].

Capillary gas chromatography (GC) with subsequent mass spectrometric detection (MS) of analytes (GC-MS) is most frequently applied to perform instrumental analysis of phthalates [11]. A most widely applied technique in gas chromatography analysis of phthalates in food products is derivatization (primarily etherification); it is done in order to make analyzed compounds more volatile as phthalates boil at rather high temperature (from $284{ }^{\circ} \mathrm{C}$ to $490.6{ }^{\circ} \mathrm{C}$ ), and chromatographic separation on capillary columns is limited to $280{ }^{\circ} \mathrm{C}-300{ }^{\circ} \mathrm{C}[12,13]$. As a result, sample preparation becomes more complicated and, consequently, there are higher risks of secondary contamination and a decrease in determination sensitivity.

Ion traps (IT), single quadruple (Q), and triple quadruple (QQQ) are used as mass analyzers in gas chromatography. Phthalates molecules are fragmented with electronic ionization (EI) and as a result a fragmented ion is 
formed with its mass-to-charge being equal to $149 \mathrm{~m} / \mathrm{z}$, and this ion is common for most phthalates. It imposes certain limits on applying GC-MS for analyzing mixtures that contain phthalates and their isomers, first of all, due to joint elution of analytes with the same mass but different molecule structure $[14,15]$.

Liquid chromatography/mass spectrometry (LC-MS) is an alternative for GC-MS. Tandem quadruple mass spectrometer provides high selectivity, especially when separating phthalates isomers, and sensitivity of determination [3, 14, 16-18]. Electrospray ionization (ESI) is most frequently applied to ionize phthalates; in few cases chemical ionization is applied for the purpose [16]. Positive ionization mode is usually applied to analyze phthalates diethers while negative ionization one provides better sensitivity for detecting monophthalates [19]. A basic issue which arises in analyzing phthalates in food products for children with LC-MS with electrospray ionization is how to achieve ion signals inhibition related to use of buffers in analysis with interfering influences exerted by components of sample matrix and poor chromatographic separation. To resolve it, various strategies can be applied, for example, improved procedures for samples treatment and/or higher resolution of chromatographic separation [3]. High performance LC-MS and LC-MS-MS are rarely used as liquid chromatographers are more prone to contamination than gas ones due to greater number of potential contamination sources such as solvents applied for extraction and chromatographic separation, chemical reagents, filters, tubes, etc. [20, 21].

To analyze 27 phthalates in milk and dairy products, experts applied a relatively innovative analytic procedure, high-performance liquid chromatography with quick resolution together with a mass-spectrometric detector with an Orbitrap (UHPLC-Q-Orbitrap) in electrospray ionization mode. The authors pointed out that if an orbit ion trap was applied, accompanying matrix compounds could be easily excluded out of analysis and it facilitated phthalates identification and quantitative determination [22].
Mass-spectrometric detectors applied in gas and liquid chromatography to quantitatively determine phthalates in food products for children are mostly calibrated with internal standard and more rarely with absolute calibration; it is due to complex sample preparation that includes multi-stage procedures for extracting and purifying an obtained extract from matrix components. There are several compounds which are most frequently used as internal standards; they are deuterated compounds such as $\mathrm{d}^{10}$-phenanthrene, $\mathrm{d}^{4}$-di(2ethylhexyl) phthalate or $\mathrm{d}^{4}$-dibutyl phthalate, as well as non-deuterated ones, for example, benzyl butyl phthalate (BBP), anthracene, pyrene, or dibutyl adipate (DBA) [16]. In some research individual deuterated internal standards are applied for each analyzed phthalate which proves that various phthalates behave differently during extraction and further treatment of an obtained extract [16].

Sample preparation that includes analytes extraction out of matrix and extract purification from interfering influences exerted by accompanying components is a significant stage in analyzing phthalates in food products for children as sensitivity and precision of determining phthalates concentrations depends on efficient selective extraction of analytes. Methodical and scientific-technical literature describes a great variety of techniques for phthalates extraction and it proves that the task is truly complicated and far from being solved completely. Most techniques are aimed at phthalates determination in breast milk [23-26], milk mixtures for children [27-30], and natural milk [22]. There are very few works on analysis of phthalates in milk cereals and canned meat, and we can say there are one or two papers that dwell on determining phthalates in food products for children which are consumed by them during their first year of life in addition to breast milk [29, 13]. Practically every published research work confirms that food products for children are contaminated with phthalates.

At present, to extract phthalates out of food products which are a complex multicomponent biological sample, the following 
techniques can be applied: liquid-liquid extraction (LLE) [25, 31-34], headspace-solid phase micro-extraction (HS-SPME) [35], diffusion solid phase extraction QuEChERS [22], solid phase extraction (SPE) [23], automated online solid phase extraction $[23,36]$. Some of them have certain limits, for example, high variability of results due to unstable quantity of components in composure of samples from one matrix; necessity to purify extracts thoroughly in order to prevent contamination of analytical equipment and it takes a lot of time to do it; complexity related to separating an extract and a product matrix after extraction; application of complex sample preparation which is not quite relevant for a routine analysis procedure.

Liquid extraction accompanied with extracts being purified from milk fats is the most widely used procedure for extracting phthalates out of milk and milk mixtures. Most authors prefer to use acetonitrite as a solventextractant among polar and non-polar organic solvents applied in extraction procedures for organic compounds [13, 22]. In some cases extraction is then followed by a sample being dried and then repeatedly dissolved in a solvent suitable for a research procedure; there can also be re-extraction in order to further purify an extract. Due to some additional procedures, concentrations of certain phthalates go up, for example, there is an increase in dibutyl phthalate (DBP) and bis(2-ethylhexyl) phthalate (BEHP) in field blanks, and it results in a procedure being less sensitive.

Direct extraction of phthalates out of food products for children via solid phase extraction with automated systems usually involves secondary contamination of analyzed samples and field blanks in the same way as with other sample preparation techniques [26, 33].

Liquid extraction is applied to purify extracts from fats, proteins, and other matrix components. When analyzing phthalates in milk and milk products, including milk mixtures and milk cereals, researchers successfully purify an acetonitrite extract with hexane; the procedure is based on better solubility of phthalates in acetonitrite, and milk fats, in hexane. Depending on how contaminated extracts are with animal and vegetable fats, the authors recommend to perform re-extraction twice or three times [37].

Size-exclusion chromatography (SEC) is frequently applied as a purification procedure after liquid extraction of milk samples [24] and milk mixtures [29]. When samples are purified with it, phthalates concentration in field blanks is determined within a range from $0.1 \mu \mathrm{g} / \mathrm{kg}$ to several $\mu \mathrm{g} / \mathrm{kg}$.

Size-exclusion chromatography (gel chromatography) based on separating molecules from various compounds as per their size means that big molecules can't penetrate sorbent pores and elute earlier than smaller molecules which can penetrate pores and remain on a sorbent. This technique is more and more frequently seen as an efficient sample preparation procedure for determining organic contaminants in lipid matrices. Phthalates with molecular masses within 200 to 4000 Daltons range are separated from lipids with molecular mass about 800 Daltons on GPC columns. classic GPC separation is performed on big columns being $400 \mathrm{~mm}$ long and having an internal diameter equal to $25 \mathrm{~mm}$ under low pressure and operating speed being $5 \mathrm{ml} / \mathrm{min}$ [38, 39]. An example when size-exclusion chromatography was successfully applied for analyzing phthalates is a procedure for purifying an extract from milk fat with gelpenetration chromatography (GPC). An extract that contained phthalates and milk fat was fractioned on S-X3 zeolite under eluting with a mixture of cyclohexane and ethyl acetate, the volume ration of solvents being 9:1. Two fractions F1 and F2 (Figure1) that contained substances being analyzed were collected separately; F1: 43-50 minutes, and F2: 50-82 minutes; concentrated to a volume equal to $1 \mathrm{~cm}^{3}$ in nitrogen flow and directly analyzed with gas chromatography with mass spectrometry (GC-MS).

Size-exclusion chromatography can be miniaturized and it significantly reduces consumption of solvents. When equipment for HPLC is applied (isocratic pump, auto-sampler able to introduce a sample with its volume 


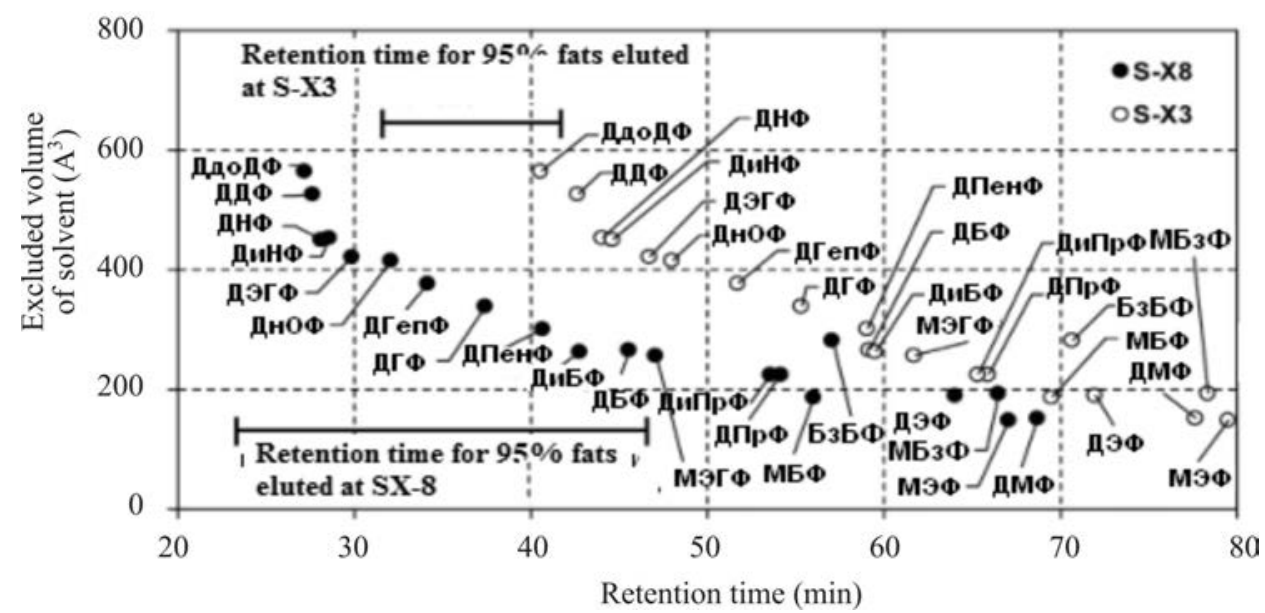

Figure 1. Retention time (min) for di-ethers and mono-ethers of o-phthalic acid on S-X8 and S-X3 zeolites under eluting with a mixture of cyclohexane and ethyl acetate, the volume ration of solvents being 9:1 at a speed equal to $4.5 \mathrm{~cm}^{3} / \mathrm{min}$ : МЭФ is mono-ethyl phthalate, МБзФ is mono-benzyl phthalate, МБФ is mono-butyl phthalate, МЭГФ is mono-(2-ethylhexyl) phthalate, ДМФ is di-methyl phthalate, ДЭФ is di-ethyl phthalate, ДПрФ is di-propyl phthalate, ДиПрФ is di-isopropyl phthalate, БзБФ is benzyl butyl phthalate, ДБФ is di-butyl phthalate, ДиБФ is di-isobutyl phthalate, ДПенФ is dipentyl phthalate, ДГекс $\Phi$ is di-hexyl phthalate, ДГеп $\Phi$ is di-heptyl phthalate, ДнОФ is di-n-octyl phthalate, ДЭГФ is bis-(2-ethylhexyl) phthalate, ДиНФ is di-isononyl phthalate, ДНФ is di-nonyl phthalate, ДДФ is di-decyl phthalate, ДдоДФ is di-dodecyl phthalate

being up to $500 \mu 1$, column thermostat, UV-detector with variable wave length, and a device to collect fractions), separation is performed at a speed equal to $1 \mathrm{ml} / \mathrm{min}$ with dichloromethane on a column which is $300 \mathrm{~mm}$ long and has an internal diameter equal to $7.5 \mathrm{~mm}$, with sorbent particles sized $5 \mu \mathrm{m}$ and pores size being equal to 5 nanometers. Pores size equal to 5 nanometers matters a lot as it allows to separate organic compounds with their masses within 100-1000 range. Better resolution is achieved when two columns are used.

Feng Y., Zhu J., Sensenstein R. examined how to apply headspace solid phase microextraction (HS-SPME) in order to exclude milk fat out of samples before GC-MS when analyzing phthalates in milk. The procedure is based on creating a vapor phase above a milk sample when it is being heated in a hermetic vessel, absorption of analyzed phthalates extracted into a vapor phase on poly-dimethylsiloxane fiber and thermodesorption of analytes directly into a chromatographic column of a gas chromatographer for analysis. The researchers reported that extraction took a long time (the shortest extraction period lasted for
60 minutes at $90{ }^{\circ} \mathrm{C}$ ). Detection limits for phthalates varied from $0.1 \mu \mathrm{g} / \mathrm{kg}$ to $100 \mu \mathrm{g} / \mathrm{kg}$ depending on how fat milk samples were. When extraction on SPME fiver was performed, milk fats were absorbed together with phthalates, and there were a lot of interfering peaks detected on a chromatograph in analysis of a sample with gas chromatography [35].

QuEChERS technique applied for extracting and purifying when phthalates are detected in cow's milk allows to achieve smaller secondary contamination at a level lower than $1 \mu \mathrm{g} / \mathrm{kg}$ [22].

We analyzed methodical and scientific literature that focused on techniques for phthalates determination in food products consumed by children in addition to breast milk during the first year of life and revealed that there were very few works that dwelled on phthalates determination in canned meat and milk cereals for children. Phthalates are usually determined in canned meat for children nutrition with gas and liquid chromatography; the procedure involves chemical analysis of a mixture that includes three biological matrices, a meat one (protein compo- 
nent of food), fat-containing one (fats in a product), and cereal-fruit-vegetable one (carbohydrates); each matrix, on one hand, has a complicated multi-component structure, but on the other hand, it has its specific peculiarities related to a chemical structure of a product.

According to the State Standard R 546282011 "Food products for children nutrition. Canned meat. Puree for younger children. Technical conditions", the following raw materials can be used to manufacture canned meat:

- meat (beef, veal, pork, rabbit meat, and others);

- oil (sunflower, soya, or corn oil; butter), lard;

- starch (potato, corn, or rice one);

- salt and water.

$100 \mathrm{~g}$ of canned meat that can be given to children starting from the 4th month of life contain 2.5-3.0 g of proteins, 2.6-3.0 g of fats, and 6.7-9.3 $\mathrm{g}$ of carbohydrates recalculated as per dry weight; $100 \mathrm{~g}$ of canned meat mixed with cereals and vegetables and aimed for children aged from 6 months to 1 year contain 2.5-9.8 g of proteins, 3.0-9.5 $\mathrm{g}$ of fats, and 2.9-8.0 g of carbohydrates recalculated as per dry weight. Component structure that analyzed products have exerts its influence on a sample preparation procedure, background contamination level, and, consequently, on sensitivity and precision of measurement procedures aimed at determining phthalates concentrations in food products for younger children's nutrition.

M. Russo et al. applied GC-MS procedure to determine 6 phthalates (DMP, DEP, DBP, DiBP, BBP, and DEHP) in food products for children (canned puree for children made of chicken and rabbit meat as well as freeze-dried samples of chicken, turkey, sea bream, and flatfish); they applied liquid-liquid extraction to extract target components with heptane with a sample being treated with ultrasound. The authors describe a problem related to preparing puree samples: intense mixing led to formation of a jelly-like emulsion, and it was next to impossible to extract an organic phase out of it thus blocking any further extraction. Developers of the procedure explain it through occur- rence of surfactants which are usually added to stabilize a product. To solve the problem, it was suggested to freeze-dry children nutrition before extraction and purification. Each sample was dried out for 4 hours at $-52{ }^{\circ} \mathrm{C}$ and pressure being equal to $0.08 \mathrm{mbar}$ in a device aimed for freeze-drying. The authors recommend to add $\mathrm{NaCl}$ solution into samples and treat them with ultrasound as it can help to destruct the emulsion. When conditions were optimized, phthalates extraction amounted to $96.2-109.2 \%$ with extraction inaccuracy being equal to $\leq 10,5 \%$, and the bottom detection limit being $20 \mu \mathrm{g} / \mathrm{kg}$ [13].

Petersen J. and Breindahl T. focus on phthalates determination with GC-MS in 11 various products for younger children (fruit, cereals, rice mixed with fruit, or meat mixed with vegetables). To prepare samples, the authors applied liquid-liquid extraction with pentane and then purified an obtained extract with a mixture of ethyl acetate/cyclohexane (1:1); a supernatant (pentane extract) was further purified with gelpenetration chromatography (GPC), dried, and re-dissolved for being analyzed with chromatomass-spectrometry. Detection limits for DBP, BBP, and DEHP amounted to 0.35, 0.015 and $0.25 \mu \mathrm{g} / \mathrm{kg}$ respectively, extraction degree varied from 76 to $128 \%$ [29].

So, it is rather difficult to prepare samples of children nutrition for analyzing phthalates concentrations in them with chromato-massspectrometry (both GS-MS and LC-MS); in addition to that, an issue related to secondary contamination of samples with analyzed compounds during their preparation and analysis hasn't been resolved yet. Phthalates are widely spread in the environment and they can be detected practically in any piece of laboratory equipment and in the air inside any laboratory. Given that, practically all the researchers who deal with phthalates pay their special attention to this issue and try out to develop and recommend various measures aimed at reducing background contamination with phthalates in laboratories, air inside them, equipment, reagents, solvents, laboratory vessels and materials.

Thus, Bubba M., Ancillotti C., Checchini L. suggest to analyze phthalates in a clean room 
equipped with high-performance filters that purify air with absorbed carbon. Excess pressure should be maintained within the room in order to avoid any air contamination from outside. Special attention is paid to purification of reagents which is performed as follows: first, sodium chloride is heated for 12 hours at $450{ }^{\circ} \mathrm{C}$ in a muffler and kept in a glass bottle until it is used. Anhydrous sodium sulfate and fiberglass filters are also treated and kept at $150{ }^{\circ} \mathrm{C}$ before application. Aluminum oxide is purified under $450{ }^{\circ} \mathrm{C}$ for a night and then applied immediately. Distilled water of HPLC range is purified with hexane for three times. Cyclohexane is treated with purified aluminum oxide ( $30 \mathrm{~g}$ of $\mathrm{Al}_{2} \mathrm{O}_{3}$ per a liter of solvent) via manual shaking during $30 \mathrm{sec}$ and then it passes through a purified fiberglass filter. Glass vessels are washed before application with hot potassium hydroxide solution in methanol, hot chrome mixture, and purified water, and then they are dried completely under $300{ }^{\circ} \mathrm{C}$ for an hour. Glass vessels for taking and preparing milk samples are washed with isopropyl alcohol before application. As a result, when breast milk samples and milk mixtures were analyzed, DiBP concentration in field blanks (samples without milk or milk products which underwent the complete sample preparation procedure) amounted to 0.79-1.08 $\mu \mathrm{g} / \mathrm{kg}$; DBP one, $0.27-0.36 \mu \mathrm{g} / \mathrm{kg}$; and DEHP one, $0.88-1.14 \mu \mathrm{g} / \mathrm{kg}$; against $18-25$ $\mu \mathrm{g} / \mathrm{kg}$ for DiBP, $6.2-11 \mu \mathrm{g} / \mathrm{kg}$ for DBP, and 18 $75 \mu \mathrm{g} / \mathrm{kg}$ DEHP in the analyzed samples [12].

Ren $R$. notes that there is a potential risk of secondary contamination at any stage in an analytical procedure including sampling, preparing a food product sample for analysis, and chromatographic analysis itself. In order to reduce contamination of materials with phthalates, various purification procedures are suggested. In most cases it is recommended to treat all glass units (sampling containers, pipettes, volumetric flasks, centrifuge vials, and other laboratory vessels) which are applied during analysis; they should be thoroughly washed in strong oxidizers and rinsed with organic solvents before application. The authors of the paper usually keep clean vessels under $400{ }^{\circ} \mathrm{C}$ for 8 hours, wash them in hexane for
12 hours and then dry at $120^{\circ} \mathrm{C}$ before application. Field blanks are analyzed with gas chromatography-mass spectrometry techniques simultaneously with samples of artificial milk mixtures so that probable secondary contamination of samples that occurs when samples are being prepared for analysis is taken into account. DEHP was the single phthalate out of 17 which was detected in field blanks in a concentration equal to $3.2 \mu \mathrm{g} / \mathrm{kg}$ [33].

As a rule, thorough treatment of laboratory equipment, vessels, auxiliary materials, reagents and solvents reduces phthalates concentration in field blanks which are usually samples prepared for analysis but without any contents of examined products in them, but it can't completely resolve an issue related to secondary contamination of analyzed samples. It is obligatory to analyze field blanks for each series of analyzed samples in order to take into account background contents when calculating ultimate phthalates concentrations in food products.

A lot of researchers note that background contamination can probably be decreased via reducing a number of procedures applied to prepare samples for analysis [10, 20, 33].

So, all the accomplished research on examining and analyzing methodical approaches to phthalates determination in food products for younger children indicate that it is vital to develop highly sensitive, selective, and highprecision determination procedures taking into account interfering influences exerted by component structure of matrices which are specific for a specific food product. To achieve as complete extraction of analyzed compounds as possible, it is necessary to apply new sample preparation procedures which should be simplified as regards extraction and purification of complicated matrices such as milk, milk mixtures, or canned meat; it is also advisable to apply reliable techniques aimed at reducing background influences exerted by phthalates which are present everywhere in the environment.

Funding. The research was not granted any sponsor support.

Conflict of interests. The authors state there is no any conflict of interests. 


\section{References}

1. Yen T., Lin-Tan D.-T., Lin J.-L. Food safety involving ingestion of foods and beverages prepared with phthalate-plasticizer-containing clouding agents. Journal of the Formosan Medical Association, 2011, no. 110, pp. 671-684.

2. Fasano E., Bono-Blay F., Cirillo T., Montuori P., Lacorte S. Migration of phthalates, alkylphenols, bisphenol A and di(2-ethylhexyl)adipate from food packaging. Food Control, 2012, no. 27, pp. $132-138$.

3. Gallart-Ayala H., Nunez O., Lucci P. Recent advances in LC-MS analysis of food-packaging contaminants. Trends in Analytical Chemistry, 2013, no. 27, pp. 99-124.

4. Gupta R. Reproductive and developmental toxicology editor, second edition. - KY, Breathitt Veterinary Center, Murray State University, Hopkinsville Publ., 2017.

5. Eveillard A., Mselli-Lakhal L., Mogha A., Lasserre F., Polizzi A., Pascussi J. Di-(2-ethylhexyl)-phthalate (DEHP) activates the constitutive androstane receptor (CAR): A novel signaling pathway sensitive to phthalates. Biochemical Pharmacology, 2009, no. 77, pp. 1735-1746.

6. Cerbulis J., Ard J. Method for isolation and detection of dioctyl phthalate from milk lipids // Association of Official Analytical Chemists, 1967, no. 50, pp. 646-650.

7. Williams D. Gas chromatographic determination of low levels of di-(2-ethylhexyl)phthalate in soy oil. Association of Official Analytical Chemists, 1973, vol. 56, no. 1, pp. 181-183.

8. Sanitarno-epidemiologicheskie pravila i normativy SanPiN 2.3.2.1940-05. Prodovol'stvennoe syr'e i pishchevye produkty. Organizatsiya detskogo pitaniya (s izmeneniyami na 27 iyunya 2008 goda). Available at: https://base.garant.ru/12138699 (10.11.2018).

9. ScienceDirect. Available at: https://www.sciencedirect.com (17.08.2018).

10. Leo M. Analysis of Endocrine Disrupting Compounds in Food. Iowa: Blackwell Publ., 2011, $491 \mathrm{p}$.

11. Wei T. Analysis of phthalates in foods by using gas chromatography mass-spectrometry (GC-MS). Researhc report submitted in fulfillment of the requirements for the degree of master of science. Department of chemistry, Faculty science Universiti of Malaya Publ., Kuala Lumpur, 2014, p. 53.

12. Bubba M., Ancillotti C., Checchini L, Fibbi D., Rossini D., Ciofi L., Rivoira L., Profeti C., Orlandini S., Furlanetto S. Determination of phthalate diesters and monoesters in human milk and infant formula by fat extraction, size-exclusion chromatography clean-up and gas chromatographymass spectrometry detection. Journal of Pharmaceutical and Biomedical Analysis, 2018, no. 148, pp. 6-16.

13. Russo M., Avino P., Notardonato I. Fast analysis of phthalates in freeze-dried baby foods by ultrasound-vortex-assisted liquid-liquid microextraction coupled with gas chromatography-ion trap/mass spectrometry. Journal of Chromatography A, 2016, no. 1474, pp. 1-7.

14. Hu J., Feng T., Li W., Zhai H., Liu Y., Wang L., Hu C., Xie M. Surface molecularly imprinted polymers with synthetic dummy template for simultaneously selective recognition of nine phthalate esters. Journal of Chromatography A, 2014, no. 1330, pp. 6-13.

15. Llompart M., Celeiro M., Lamas J., Sanchez-Prado L., Lores M., Garcia Jares C. Analysis of plasticizers and synthetic musks in cosmetic and personal care products by matrix solid-phase dispersion gas chromatography-mass spectrometry. Journal of Chromatography A, 2013, no. 1293, pp. 10-19.

16. Gonzalez-Salamo J., Socas-Rodriguez B., Hernandez-Borges J. Analytical methods for the determination of phthalates in food. Current Opinion in Food Science, 2018, no. 22, pp. 122-136.

17. Masia A., Moliner-Martinez Y., Munoz-Ortuno M., Pico Y., Campíns-Falco P., Multiresidue analysis of organic pollutants by in-tube solid phase microextraction coupled to ultra-high performance liquid chromatography-electrospray-tandem mass spectrometry. Journal of Chromatography A, 2013, no. 1306, pp. 1-11.

18. Xu D., Deng X., Fang E., Zheng X., Zhou Y., Lin L., Chen L., Wua M., Huang Z. Determination of 23 phthalic acid esters in food by liquid chromatography tandem mass spectrometry. Journal of Chromatography A, 2014, no. 1324, pp. 49-56. 
19. Tranfo G., Papaleo B., Caporossi L., Capanna S., De Rosa M., Pigini D., Corsetti F., Paci E. Urinary metabolite concentrations of phthalate metabolites in Central Italy healthy volunteers determined by a validated HPLC/MS/MS analytical method. International Journal of Hygiene and Environmental Health, 2013, vol. 216, pp. 481-485.

20. Yang J., Li Y., Wang Y., Ruan J., Zhang J., Sun C. Recent advances in analysis of phthalate esters in foods. Trends in Analytical Chemistry, 2015, no. 72, pp. 10-26.

21. Hayasaka Y. Analysis of phthalates in wine using liquid chromatography tandem mass spectrometry combined with a hold-back column: Chromatographic strategy to avoid the influence of pre-existing phthalate contamination in a liquid chromatography system. Journal of Chromatography A, 2014, no. 1372, pp. 120-127.

22. Jia W., Chu X., Ling Y., Huanga J., Chang J. Analysis of phthalates in milk and milk products by liquid chromatography coupled to quadrupole Orbitrap high-resolution mass spectrometry. Journal of Chromatography A, 2014, no. 1362, p. 110-118.

23. Calafat A., Slakman A., Silva M., Herbert A., Needham L. Automated solid phase extraction and quantitative analysis of human milk for 13 phthalate metabolites. Journal of Chromatography $A, 2004$, vol. 805, no. 1, pp. 49-56.

24. Hogberg J., Hanberg A., Berglund M., Skerfving S., Remberger M., Calafat A., Filipsson A., Jansson B., Johansson N., Appelgren M., Håkansson H. Phthalate diesters and their metabolites in human Breast milk, blood or serum, and urine as biomarkers of exposure in vulnerable populations. Environmental Health Perspectives, 2008, vol. 116, no. 3, pp. 334-339.

25. Mortensen G., Main K., Andersson A., Leffers H., Skakkebæk N. Determination of phthalate monoesters in human milk, consumer milk, and infant formula by tandem mass spectrometry (LC-MS-MS). Analytical and Bioanalytical Chemistry, 2005, vol. 382, no. 4, pp. 1084-1092.

26. Zimmermann S., Gruber L., Schlummer M., Smolic S., Fromme H. Determination of phthalic acid diesters in human milk at low ppb levels. Food Additives \& Contaminants: Part A, 2012, vol. 29, no. 11 , pp. $780-1790$.

27. Bradbury J. UK panics over phthalates in baby milk formulae. Lancet, 1996, no. 347, pp. 1541.

28. Bradley E., R. Burden, Leon I., Mortimer D., Speck D., Castle L. Determination of phthalate diesters in foods. Food Additives \& Contaminants: Part A, 2013, no. 30, pp. 722-734.

29. Petersen J., Breindahl T. Abstract in total diet samples, baby food and infant formulae. Food Additives \& Contaminants: Part A, 2000, vol. 17, no. 2, pp. 133-141.

30. Tsumura Y., Ishimitsu S., Kaihara A., Yoshii K., Tonogai Y. Phthalates, adipates, citrate and some of the other plasticizers detected in Japanese retail foods: a survey. Journal of Health Sciences, 2002, no. 48, pp. 493-502.

31. Cirillo T., Latini G., Castaldi M., Dipaola L., Fasano E., Esposito F., Scognamiblio G., Francesco F., Codellis L. Exposure to Di-2-Ethylhexyl Phthalate, Di-n-Buthyl Phthalate and Bisphenol through infant formulas. Journal of Agricultural and Food Chemistry, 2015, no. 63, pp. 3303-3310.

32. Ge V., Yang X., Wu X., Wang Z., Geng W., Guo C. Phthalate residue in goat milk-based infant formulas manufactured in China. Journal of Dairy Science, 2016, vol. 99, no. 10, pp. 7776-7781.

33. Ren R., Jin Q., He H., Bian T., Wang S., Fan J. Determination of 17 phthalate esters in infant milk powder and dairy products by GC-MS with 16 internal standards. Chromatographia, 2016, no. 13-14, pp. 903-910.

34. Sorensen L. Determination of phthalates in milk and milk products by liquid chromatography/tandem mass spectrometry. Rapid Communications in Mass Spectrometry, 2006, vol. 20, no. 7, pp. 1135-1143.

35. Feng Y., Zhu J., Sensenstein R. Development of a headspace solid-phase microextraction method combined with gas chromatography mass spectrometry for the determination of phthalate esters in cow milk. Analytica Chimica Acta, 2005, vol. 538, no. 1-2, pp. 41-48.

36. Lin S., Ku H., Su P., Chen J., Huang P., Angerer J., Wang S. Phthalate exposure in pregnant women and their children in central Taiwan. Chemosphere, 2011, vol. 82, no. 7, pp. 947-955. 
37. Tienpont B. Determination of Phthalates in Environmental, Food and Biomatrices - An Analytical Challenge. Department of Organic Chemistry Ghent University, 2004. Available at: http://www.researchgate.net/publication/267703038 (17.08.2018).

38. Specht W., Tilkes M., Frezenius Z. Gas-chromatographische Bestimmung von Rückständen an Pflanzenbehandlungsmitteln nach Clean-up über Gel-Chromatographie und Mini-KieselgelSäulen-Chromatographie. Analytical Chemistry, 1980, no. 301, 300 p.

39. Thier H., Zeumer H. Manual of Pesticide residue Analysis. VCH, Weinheom, 1987, vol. 1, pp. 75.

Ulanova T.S., Karnazhitskaya T.D., Zorina A.S. Techniques for determining phthalates in food products aimed for infants' nutrition: an overview. Health Risk Analysis, 2019, no. 1, pp. 154-163. DOI: 10.21668/health.risk/2019.1.17.eng

Received: 21.01.2019

Accepted: 11.03.2019

Published: 30.03.2019 


\section{NEW LEGAL, REGULATORY AND METHODOLOGICAL DOCUMENTS ISSUED IN THE RF IN THE SPHERE OF HEALTH RISK ANALYSIS}

05.12.2018-01.03.2019

The Recommendation by The Board of the Eurasian Economic Commission (EEC) No. 28 dated December 18, 2018 "On the procedure for electronic interaction between a customs authority and authorized bodies in a EAEU member-state that are responsible for control (surveillance) at the EAEU customs border, when preliminary informing is to be accomplished"

The procedure fixes, among other things, situations in which electronic interaction should occur, list and structure of data which should be submitted to authorized bodies in the sphere of sanitaryepidemiologic welfare of the population, veterinary sphere, and quarantine for plants. It envisages application of guides and classifiers which are included as resources in the EAEU unified system of regulatory and reference information as well as guides and classifiers which are applied for customs purposes, created and meant for application in accordance with the legislation of a EAEU member-state.

The Decision by The Board of the Eurasian Economic Commission (EEC) No. 2 dated January 15, 2019 "On Approval of data concerning issued certificates on state registration of a product which can be received by customs authorities in the EAEU member states and a procedure according to which such data can be obtained"

The decision fixes the structure of data concerning certificates on state registration of products issued to confirm that a product is in compliance with the obligatory requirements fixed in the EAEU and CU technical regulations or with the Unified sanitary-epidemiologic and hygienic requirements. Such data, among other things, should include: a register number of a certificate, date of issue or registration, its status; denomination of a manufacturer, an address of a juridical person and an address where this juridical person manufactures products; denomination of an applicant or recipient, an address where a juridical person performs its activities and/or where a private entrepreneur lives; data on a product: denomination, identifiers (type, model, mark, article, etc.), registration number; denomination of an author- ized body in a EAEU member-state that issued the certificate and its address; titles and denomination of documents according to which products were manufactured; denomination of a legal document compliance with which should be confirmed by the certificate; data on documents confirming compliance of a product with obligatory requirements.

The above mentioned data are obtained by customs authorities in the EAEU member states via an enquiry to the EAEU integrated information system entitled "Application of databases containing data on documents issued by authorized bodies in the EAEU member states in the sphere of regulating foreign and mutual trade, including those submitted when customs procedures are being accomplished in order to confirm that all embargoes and limitations are observed".

The Decision by The Board of the Eurasian Economic Commission (EEC) No. 3 dated January 15, 2019 "On Approval of the list of products for which a customs declaration should be supplemented with a document on assessing conformity to the requirements fixed in the EAEU Technical Regulations "On safety of amusement rides (TR EAEU 038/2016)"

The Decision fixes a list of products for which a customs procedure requires an additional document confirming that they are in compliance with the requirements fixed in the Technical regulations "On safety of amusement rides" (TR EAEU 038/2016). The above-mentioned list includes mobile (temporary) amusements rides and stationary amusements rides (erected on foundations or without them) (EAEU CN FEA code 9508900000 ) with potential biomechanical risk degree RB-1 (certificate of conformity is to be submitted) and with potential biomechanical risk degree RB-2 and RB-3 (declaration of conformity is to be submitted).

The Decision by The Board of the Eurasian Economic Commission (EEC) No. 7 dated January 15, 2019 "On making alterations into the Decision 
by the Board of the Eurasian Economic Commission (EEC) No. 55 dated March 26, 2013 "

The Decision expands the program on developing (making alterations into or reviewing) interstate standards application of which provides voluntary compliance with the requirements fixed in the technical regulations "On safety of products for children and teenagers" (CU TR 007/2011)

The above-mentioned program now includes 16 additional items among which there are: Footwear for children. Technical specifications. Revision of the State Standard R 26165-2003; Latex nipples for children. Technical specifications. Development of a new state standard based on the State Standard R 51068-97; Cutlery and cooking appliances made of corrosion-resistant steel. Overall technical specifications. Development of a new state standard based on the State Standard R 51687-2000. Books and magazines for children and teenagers. Hygienic requirements. Development of a state standard based on the Sanitary-Epidemiologic requirements 2.4.7.960-00.

The Decision by The Board of the Eurasian Economic Commission (EEC) No. 13 dated January 29, 2019 "On the Procedure for introducing alterations into the Customs Union Technical Regulations "Food products as regards their marking" (CU TR 022/2011)"

The Decision fixes a term during which food products marked in accordance with the previously set requirements can be distributed on the market. Within 24 months since the date when alterations come into force it is allowed to produce and distribute food products on the EAEU customs territory with their marking corresponding to the $\mathrm{CU}$ Technical Regulations "Food products as regards their marking" (CU TR 022/2011) approved on December 9, 2011 by the Decision of the Customs Union Commission No.881. The above mentioned products can be distributed up to the expiration date fixed by their manufacturers.

The Federal Law No. 480-FZ dated December 25, 2018 "On making alterations into the Federal Law "On protecting rights of juridical persons and private entrepreneurs when accomplishing state control (surveillance) and municipal control" and Clause 35 of the Federal Law "On water supply and sewerage"

The Law fixes that in 2019-2020 scheduled inspections can be accomplished on objects belonging to small and medium-sized businesses only in the following cases:
- scheduled inspections are accomplished within state control (surveillance) spheres for which risk categories, and hazard classes (categories) as well as criteria for assigning activities performed by juridical persons or private entrepreneurs into a specific risk category are fixed;

- scheduled inspections accomplished at objects belonging to juridical persons or private entrepreneurs whose activities are included into lists issued by the RF Government;

- scheduled inspections accomplished at objects belonging to economic entities that were accounted to administrative responsibility for gross violation of obligatory requirements;

- scheduled inspections accomplished concerning activities for which a license is required.

The Federal Law No. 488-FZ dated December 25, 2018 "On making alterations into the Federal Law "On the basics of state regulation over trading activities in the Russian Federation" and Clauses 4.4 and 4.5 of the Federal Law "On application of POS equipment when making payments in the Russian Federation"

The Law approves creating an information system for monitoring over distribution of marked goods and automation of processes for their tracking.

The legislative base is supplemented with the following concepts: "goods marked with identification means", "goods which are to be marked with identification means", "an identification mean" (it is usually a marking code that can be read by a machine, including bar codes), "a verification code" (it is usually a sequence of symbols formed as a result of encrypting transformation of an identification code that allows to detect its probable falsification) etc.

Economic entities that deal with distribution of such goods are to provide an operator of an information system for monitoring with all the necessary data in accordance with the rules fixed by the RF Government. An operator of an information system for monitoring is not an operator who deals with revenue data. Public data will be placed by an operator in the Internet

The RF President Message to the Federal Assembly on February 20, 2019

To achieve new life quality for each generation and dynamic development of the country, the RF President set the following tasks :

- from January 1, 2020, each family member in the RF should be provided with at least two living wages; from July 1 this year a social welfare payment given to those who take care of disabled 
children and of people with the disability group 1 who have been disabled since their childhood should be equal to 10,000 rubles per month; families with many children should receive greater tax exemption as regards real estate tax; plots up to 6 hundred square meters should be completely taxfree; mortgage rates are to be reduced gradually; if a second child is born in a family it should be granted credit relaxation for the overall mortgage term; a growth in tax payment for land plots is to be limited; not less than 270 thousand new places in nurseries should be created by the end of 2021; citizens should be provided with greater opportunities to receive new knowledge and skills required for employment and stable income (a social contract); citizens who have lost sources of incomes should be granted a delay in mortgage payments; it is necessary to increase pensions and monthly social payments above a living wage for a retired person which is fixed annually etc.

In public healthcare:

- by the end of 2020 medical aid should be made available to citizens living in any settlement on the territory of Russia; 1,590 outpatient clinics and feldsher's stations are to be built or renovated; standards for economical polyclinics are to be developed and approved, their certification procedures are to be fixed, and ways to motivate medical personnel to raise quality of their work are to be introduced in regions. In 2021 all polyclinics for children are to operate according to new standards; within 3 years electronic interaction between medical organizations, chemists, doctors, and patients should be implemented and organization of medical and social examinations is to be included into the common digital network; any age limitations for participants in "Zemskiy doctor" program should be eliminated;

In other spheres:

- within the next two years 30 large dumps located within cities are to be closed and reclaimed, and over the next 6 years the same should be done to the rest of dumps. A share of wastes that are recycled is to be raised to $60 \%$; by the end of 2021 all schools in Russia should be provided with a high-speed Internet connection; starting from 2020, a program "Zemskiy teacher" should be implemented and teachers who move to work in rural settlements or small towns should be granted a lump-sum payment; regional and municipal museums, theaters, and libraries should be given a profit tax exemption; a new program for rural territories development should be created and implemented; starting from January 1, 2021 regulatory documents in control and surveillance sphere should become invalid, and the regulatory base should be updated before this date;

In economics, we should provide the following:

- priority growth in labor productivity; creation of competitive industries, growth in non-recourses exports;

- improvement of business environment and national competence, a 6-7\% growth in investments by 2020; elimination of infrastructural limitations to economic development in regions; development of highly qualified personnel with up-to-date skills and knowledge and creation of substantial scientific and technological base.

"The list of orders aimed at raising quality of drinking water supplied to population" (approved by the RF President on February 20, 2019 No. Pr-245)

The RF Government are to provide: creation of a mechanism for assessing health risks caused by chemical and biological properties of water taking into account WHO recommendations; the Government are to make sure that provision with water for population living in rural areas should reach the same level as for people living in cities. The executive bodies in the RF regions are to provide control over conformity of drinking water supplied to an end customer with quality and safety standards; complete implementation of investment and production programs by water supply and sewerage organizations. The RF Office of the Prosecutor General are to perform an inspection in order to control adherence to the legislation on water supply and sewerage when control and surveillance activities in the sphere are performed by executive bodies and local authorities

"The list of orders aimed at implementation of the RF President Message to the Federal Assembly (approved by the RF President)

The State Duma members are to consider and pass the following laws during their spring session 2019:

- a federal law that fixes introduction of a system for making quotas on emissions of pollutants into the air in large industrial cities, first of all, in Bratsk, Krasnoyarsk, Lipetsk, Magnitogorsk, Mednogorsk, Nizhniy Tagil, Novokuznetsk, Norilsk, Omsk, Chelyabinsk, Cherepovets, and Chita;

- alterations into the RF legislation eliminating all regulatory documents that fix requirements compliance with which is to be checked within state control (surveillance) from January 1, 2021, and enforcing new standards, and updated requirements 
developed within a risk-oriented approach and contemporary technological development.

"The Chart for the national project "Ecology" (approved by the Presidium of the RF President Council on strategic development and national projects, the minutes No. 16 dated December 24, 2018)

The Council approved on the Chart for the national project "Ecology" (October 01, 2018 - December 31, 2024).

The project is aimed at achieving the following targets: efficient treatment of industrial and consumer wastes including elimination of all illegal dumps within cities which were detected and are known to still exist on the January 1, 2018; reduction of atmospheric air pollution in large industrial centers; an increase in quality of drinking water supplied to population including people living in settlements which don't have up-to-date centralized water supply systems; ecological improvement of water objects including Volga and preservation of unique water systems including Lake Baikal and Lake Teletskoe; preservation of biological variety and creation of not less than 24 new strictly protected natural zones; provision of balance between deforestation and forests reproduction in a ratio equal to $100 \%$ by 2024 .

The national project includes the following federal projects: "A clean country", "A complex system for treating solid communal wastes", "Infrastructure for treating wastes belonging to the 1 st and 2nd hazard category", "Clean air", "Clean water", "Ecological improvement for Volga", "Preservation of Lake Baikal", "Preservation of unique water objects", "Preservation of biological variety and development of environmental tourism", "Preservation of forests", "Implementation of the best available technologies".

"The Chart for the national project "Demography" (approved by the Presidium of the RF President Council on strategic development and national projects, the minutes No. 16 dated December 24, 2018)

The Council approved on the Chart for the national project "Demography" (January 01, 2019 December 31, 2024)

The project is aimed at achieving the following strategic aims: an increase in expected healthy lifespan up to 67 years; an increase in overall birth-rate (up to 1.7 children per 1 women); an increase in number of people who pursue healthy lifestyle; an increase in number of people who are physically ac- tive and do sports systematically. The national project includes the following federal projects: financial support for families with newborns; assistance to women who wish to be employed via creating pre-school children facilities for children younger than 3 ; systemic support and better life quality for elderly people; creating a system that motivates people to pursue healthy life style including healthy nutrition and giving up bad habits; creating opportunities for all population groups to be physically active and do sports, infrastructure for mass sport, as well as training for future sportsmen (sport reserves).

The RF Governmental regulation dated December 28, 2018 No. 2963-r "On Approving the concept for the creation and functioning of a system for goods marking with identification means and tracking of their movement in the RF"

The system for good marking with identification means and tracking of their movement is aimed at obtaining rapid and authentic data on movement of goods and development of high-tech decisions on creating new services and business models.

Organization of marking and tracking for goods involves the following: introduction of obligatory marking of goods with identification means based on analysis of how relevant this introduction is for this or that specific product group; making those who participate in goods distribution responsible for marking of goods with identification means according to the procedures fixed by the RF Government; making expenses on introducing marking of goods as low as it's only possible; a possibility to conduct a voluntary experiment on marking of goods; identification of each unit of goods via marking; registration of each stage in goods distribution, starting form manufacturing or import on the RF customs territory up to retail trade or any other removal or withdrawal of goods from distribution; fixing a charge for creation of a marking unit (code) for goods; providing necessary conditions for development of en efficient public control in the sphere of marked goods distribution.

The Ministry of Industry and Trade of the Russian Federation is to coordinate creation and functioning of a system for goods marking with identification means and tracking of their movement.

The RF Governmental regulation dated February 13, 2019 No. 207-r "On approving the Strategy for spatial development of the Russian federation up to 2025"

The RF Government have stated that there are the following priorities in the spatial development 
of the Russian Federation for the period up to 2025: advance development of territories which are poorly developed in terms of their socioeconomic state but have a potential for economic growth as well as territories with low population density and predictable growth in their economic potential; development of centers with promising economic growth and increase in their number and maximum spread over the RF territory; social development of territories with low population density and insufficient potential for economic growth.

The RF Governmental regulation dated December 14, 2018 No. 1536 "On making alterations into the Regulations on federal state surveillance in the sphere of consumer rights protection"

Starting from January 01, 2019 owners of Internet aggregators are subject to federal state surveillance in the sphere of consumer rights protection which includes:

- organizing and conducting inspections to determine whether owners of aggregators adhere to legal requirements in the sphere of consumer rights protection and to orders given by surveillance authorities;

- systemic observation, analysis, and prediction whether they meet obligatory requirements when accomplishing their activities.

Surveillance authorities have the right to:

- enquire and obtain data and documents on issues related to consumer rights protection;

- conduct any inspection within control procedures at objects which are under surveillance; an access should be granted to officials with service certificates and a copy of an order to conduct an inspection;

- to issue prescriptions to stop violating consumer rights, to eliminate detected violations, and to make efforts aimed at preventing any hazard to consumers' life, health, and property, and to the environment;

- to take legal actions and to hand in petitions to court to protect consumer rights, legitimate interests of broad masses of consumers as well as petitions to liquidate an aggregator for repeated (2 or more times within 1 calendar year) or severe (causing death or mass incidence, mass intoxications) violation of consumer rights.

The RF Governmental regulation dated February 28, 2019 No. 224 "On Approving the Rules for marking tobacco products with identification means and peculiarities related to implementation of the state information system for monitoring over distribution of goods which are subject to obligatory marking with identification means as regards tobacco goods"

The Regulation determines that cigarettes which are not marked with identification means can be distributed up to July 01, 2020.

Producers, importers, and sellers of tobacco products, among other things, are to register themselves in the state information system for monitoring before June 30, 2019. And if they start their activities after this date, the registration should be accomplished within 7 days since the date such activities have started.

On the RF territory cigarettes can be introduced onto the market without identification means being marked on them and data on this marking and their first sale on the market being fed into the information system for monitoring till July 1, 2019.

Retail trade in above mentioned tobacco products manufactured (imported) after July 1, 2019 is allowed only if data on such sales are fed into the state information system for monitoring.

On the RF territory distribution of cigarettes (a code as per classifier 12.00.11.130, CN FEA code 2402 20; a code as per classifier 12.00.11.140, CN FEA code 240220900 0) which are not marked with identification means is allowed only till July 1 , 2020; and distribution of other tobacco products, till July 1, 2021.

The RF Governmental regulation dated January 28, 2019 No. 50 "On making alterations into the Rules for trade in specific goods"

Milk products are to be sold according to a new procedure since July 01, 2019.

According to a supplement made into the Rules for trade in specific goods approved by the RF Government regulation dated January 1998, No. 55, milk, milk products, and products that contain milk are to be placed in a shop or any other point of sale in such a way so that a buyer can visually separate them from other food products; there should be a notice "products without milk fat substitutes".

The Regulation comes into force on July 01, 2019.

The RF Governmental regulation dated February 13, 2019 No. 149 "On developing, fixing, and reviewing standards for quality of the environment as for its chemical and physical parameters as well as on approving a list of regulatory documents in the sphere of environmental protection that fix technological parameters of the best available technologies"

The Regulation determines a procedure for developing, fixing, and reviewing standards for quality 
of the environment as regards its chemical and physical parameters. Standards are to be developed for specific environmental components, such as atmospheric air, water in surface water objects, water in underground water objects, and soils.

Quality standards are fixed at maximum permissible levels obtained via laboratory research; or, in case of territories and water basins, at background levels (within permissible deviations in values) which occurred under influence exerted by environmental factors specific for a specific area or a water basin. Background levels (an interval of permissible deviation from their values) for an area or a water basin are determined on the basis of data obtained via observations over the environment, samplings and (or) measurements as per chemical and physical parameters on a relevant reference area as well as on the basis of data taken from the unified state database on the environment, its contamination, the state water register the state fund for mineral resources, the state forests fund, the unified state register of real estate, the state ecological monitoring database (the state monitoring over the environment).

A reference area is a land spot, water objects or its part, selected within an examined territory or water basin, without any signs that their natural ecological systems have started to deteriorate (changes in species or trophic structure of ecosystems, their natural productivity, morphological or metabolic properties of soils, disappearance of animals and plants, disorders in biological cycles of animals and plants).

The RF Governmental regulation dated February 28, 2019 No. 225 "On authorized bodies in the RF that can perform control (surveillance) over adhering to the requirements fixed in the EAEU Technical Regulations "On safety of bottled drinking water including natural mineral water"

The Regulation fixes that state control (surveillance) over adhering to the requirements fixed in the EAEU Technical Regulations "On safety of bottled drinking water including natural mineral water" approved by the Decision of the EEC Board Council dated June 23, 2017 No. 45 is to be performed by the following bodies:

- Rospotrebnadzor and other federal executive bodies which are authorized to perform federal sanitary-epidemiologic surveillance within their competence and within a scope of state sanitaryepidemiologic surveillance;

- Rospotrebnadzor within federal state surveillance over consumer rights protection.

Authorized bodies in the RF exchange information in order to make their control (surveillance) competences more efficient and to prevent distribution of products which are not compliant with the requirements fixed in the above mentioned technical regulations on the RF territory.

The Order by the RF Chief Sanitary Inspector dated December 20, 2018 No. 52 "Approval of Sanitary-Epidemiologic Rules SER 3.1.3542-18 "Prevention of meningococcal infection" (Registered in the RF Ministry of Justice on January 09, 2019 No. 53254)

The Order revises requirements to conducting prevention activities aimed at prophylaxis of meningococcal infection occurrence and spread.

The Rules contain overall description of meningococcal infection and its agent; characteristics of morbidity with meningococcal infection in the RF and worldwide; ways of detecting, registering, and keeping records about patients with generalized meningococcal infection and acute nasopharyngitis; laboratory diagnostics of generalized meningococcal infection; activities performed in foci where meningococcal infection is detected; rules for organizing immune prophylaxis of meningococcal infections during a period between epidemics and when there is a threat that there can be an epidemic rise in incidence; surveillance over meningococcal infection; hygienic education provided for citizens as regards meningococcal infection etc.

The Sanitary-Epidemiologic Rules SER 3.1.2.2512-09 "Prevention of meningococcal infection" approved by the Order by the RF Chief Sanitary Inspector on may 18, 2009 No. 33 are no longer valid.

Validity of the Sanitary-Epidemiologic Rules SER 3.1.3542-18 "Prevention of meningococcal infection" expires on December 15, 2028.

The Order by the RF Chief Sanitary Inspector dated December 19, 2018 No. 49 "On preventing spread of parasites that could be caught when eating meat and meat products in the Russian Federation" (Registered in the RF Ministry of Justice on January 30, 2019 No. 53632)

The RF Chief Sanitary Inspector informs that the situation in the RF is rather tense as regards incidence with parasitic diseases caught when eating meat and meat products (trichinosis, teniarinhoze, taeniasis).

Regional authorities are urged to pay special attention to efficiency of activities aimed at eliminating rats and disinvasion at animal farms and agro-industrial enterprises; to take certain measures aimed at preventing non-sanctioned trade in 
meat and meat products; to examine quality of medical aid rendered to patients with parasitic diseases including laboratory diagnostics of such diseases; to reinforce quality control performed during inspections of meat obtained via commercial and private hunting (bear, wild boar, and badger).

Juridical persons and private entrepreneurs who deal with communal infrastructure for water supply, sewage, and sewage purification, are to take measures aimed at providing stable qualitative disinfection of environmental components and guaranteeing them being completely free of any parasites.

The Order by the Rospotrebnadzor dated December 05, 2018 No. 1000 "On Approving application forms on establishing, changing, or eliminating a sanitary hygienic zone" (Registered in the RF Ministry of Justice on January 22, 2019 No. 53491)

The Order approves application forms that should be submitted when a sanitary-hygienic zone is established, changed, or eliminated. When submitting an application on establishing or changing a sanitary-hygienic zone, it is necessary to provide data on an economic entity (developer) who owns an object which is to have a sanitary-hygienic zone around it and to substantiate its establishment; data on a project designer; data on an expert's report issued as per results of a sanitary-hygienic inspection of a sanitary-hygienic zone project. Projects of sanitary-hygienic zones and expert's reports on results of a sanitary-epidemiologic inspection are to be submitted together with applications.

Any application as regards eliminating a sanitary-hygienic zone should contain data on an applicant, an expert organization, results of atmospheric air measurements, data on physical and/or biological impacts exerted on air beyond an object, and an expert's report on a performed sanitary-epidemiologic inspection that should conation results of the abovementioned examinations (measurements).

The Letter by the Rospotrebnadzor dated November 12, 2018 No. 01/14740-2018-32 "On an expert's certificate"

An expert's certificate gives its holder a right to pursue medical activities on the RF territory up to January 01, 2026; expert's certificates may be issued up to January 01, 2021 and are valid until their expiration date. Qualifying criteria for taking up posts in state civil services (item 9 in the Reference book of qualifying criteria for specialties, education, skills, and knowledge necessary to take up a post in state civil services taking into account a sphere and type of occupational civil activities performed by civil servants (approved by the RF Ministry of Labor)) include an expert's certificate valid till January 01, 2026 that confirms its holder has a medical-prevention specialty or a certificate that conforms accreditation of an expert.

The Letter by the Rospotrebnadzor dated February 12, 2018 No. 01/1840-2018-32 "On requirements to disinfection,. disinsection, and deratization"

To perform disinfection, any juridical person should hold a license on medical activity in "disinfectiology" sphere and employ experts with relevant medical education. The standpoint is confirmed by the RF Supreme Court in the Decision dated January 15, 2018 No. 309-КГ17-12073; the Decision dated January 12, 2018 No. 310-КГ17-14344; the Review on juridical practices "On certain issues occurring during arbitrations regarding administrative infractions covered by the Chapter 14 of the RF Code on Administrative Infractions" confirmed by the RF Supreme Court Presidium on December 06, 2017 as well as by the Arbitration Court of the Urals district in its Decision dated May 04, 2017 No. F09-1737/17.

Methodical Guidelines MR 2.4.5.0131-18. 2.4.5. "Hygiene for teenagers and children. Children nutrition. Practical aspects related to organizing rational nutrition for children and teenagers and organization of monitoring over nutrition" (approved by the RF Chief Sanitary Inspector on August 10, 2018)

The documents focuses on how to organize rational nutrition for children and teenagers at schools and pre-school children facilities. According to the Guidelines, a menu should be drawn for not less than 2 weeks. It should take into account physiological needs of a body in energy and nutrients as well as actual amount of energy a child tends to spend; it should be diverse, safe, and balanced; it should include products for children nutrition which are enriched with vitamins, minerals, bifid bacteria; it should include dishes cooked with sparing treatment of ingredients that ensures taste preservation; it should envisage a possibility to provide nutrition for children who require specific food as per medical indications.

The Guidelines contain example sets of products for various meals which can be applied when organizing nutrition for children at pre-school children facilities and schools. 
The Methodical Guidelines MR 3.1.014018. 3.1. "Prevention of infectious diseases. Nonspecific prophylaxis of flu and other acute respiratory infections. Methodical Guidelines" (approved by the RE Chief Sanitary Inspector on December 10, 2018)

The Guidelines are to be used by experts employed at Rospotrebnadzor bodies and institutions, medical organizations, heads and staff at all kinds of educational establishments, establishment aimed for long-term stay of people etc. The document outlines basic features of infectious agents and risk groups; principles of non-specific prophylaxis aimed for fighting against flu and acute respiratory infections; a list of actions that can make a body more resistant to infectious agents; how to apply non-specific preventive medications; disinfection means and procedures, barriers that prevent respiratory contagion with infectious agents and how to use them; etc.

Information by Rospotrebnadzor dated January 15, 2019 "On making milk-containing products with fat substitutes"

Starting from July 15,2018 , the Customs Union Technical Regulations 033/2013 "On safety of milk and milk products" are to contain a new term, "a milk-containing product with milk fat substitute". It is a product obtained via milk processing and manufactured with application of milk fat substitute in a quantity not exceeding $50 \%$. Rospotrebnadzor reminds that a 180 -day period granted to milk products manufactures to prepare for changes in marking is soon expiring.

Denomination of a product manufactured with application of milk fat substitutes should start with the following words: "milk-containing product with milk fat substitute". A consumer package should bear the following: "contains vegetable oils". The information should be given in a font which is easy to read; marking should be made on a package side which faces a consumer. Violation of the amended requirements will result in administrative responsibility. Should consumers find any products distributed on the market which are not compliant with the fixed requirements, they have the right to apply to a regional Rospotrebnadzor office so that measures could be taken as regards manufactures, suppliers, and sellers of such products.

The Order by the Russian Federal State Statistic Service Росстата dated December 29, 2018 No. 792 "On Approval of federal statistic observation forms and instructions on how to fill them for organization of a statistical observation over sanitary situation in a $R F$ region by the Federal Service for Surveillance over Consumer Rights Protection and Human Well-being"

The Order approves a new statistical form (a monthly one and an annual one); a monthly Form No. 5 "Data on preventive vaccinations" becomes valid starting from January 2019 Report, and an annual one, starting from 2019 Annual Report. The Form is to be filled in by organizations that render medical aid to children and adults, medical and obstetric centers in rural areas, infant orphanages, as well as medical organizations which are part of the Russian Railways, The Russian Ministry of Defense, The Russian Ministry for Internal Affairs, The RF Federal Security Service, The RF Federal Protective Service, The RF Federal Service for Execution of Punishments, the RF Federal Biomedical Agency, The Main Directorate of Special Programs of the President of the Russian Federation, The National Guard of Russia, the RF President Administration. The Federal Center for Hygiene and Epidemiology is to collect all the reports and submit a consolidated one as per the country as a whole to Rospotrebnadzor.

Form No. 1 and 2 which are to contain data on infectious and parasitic diseases are also renewed.

The Letter by the RF Ministry of Construction Industry, Housing and Utilities Sector dated November 29, 2018 No. 52225-OГ/08 "On issues related to performing a state inspection"

The Ministry informs that "List of environmental protection activities" in project documents submitted to an inspection is to contain the results of assessing how an object that is being designed influences the environment; it should also contain data on activities aimed at preventing and (or) eliminating adverse effects produced by future economic activities. Project decisions should be well-grounded and validated with documents which are fixed by legal acts issued in the RF

The letter highlights that, according to the Sanitary-Epidemiologic Requirements 2.2.1/2.1.1.1200-03 "Sanitary-hygienic zones and sanitary classification of enterprises, buildings, and other objects. A new edition", sanitary-hygienic zones are to be designed at all the stages in development of project documents, construction, reconstruction and operation projects for an industrial object and production and/or a group of various productions. When production is in operation, a size of its sanitary-hygienic zone can be changed as per data collected via field research and risk assessment. 
Assessment of a sanitary-hygienic zone project performed by Rospotrebnadzor bodies is not included into an inspection of project documents for construction and reconstruction of a capital construction object; it is performed only for issuing initial permissions as regards establishing sizes and boundaries of a sanitary-hygienic zone around an object.

The Letter by the RF Federal Accreditation Service dated January 25, 2019 "On documents that should be attached to a conformity declaration that confirms compliance of products with requirements fixed in technical regulations starting from February $15,2019 "$

The RF Federal Accreditation Service reminds about documents that, starting from February 15, 2019, should be submitted together with a conformity declaration to confirm that products are compliant with requirements fixed in technical regulations.

Such documents can be the following: a copy of a contract with a manufacturer stipulating that a manufacturer is to provide compliance of products supplied onto the RF customs territory to requirements fixed in relevant technical regulations and to bear full responsibility for non-compliance of products to the above-mentioned requirements; copies of documents that validate compliance, including results of examinations and measurements. The Letter informs that a service for registration of conformity declarations will be renewed starting from February 15, 2019, and it will be impossible to register any conformity declarations about products being compliant with requirements fixed in the
RF and EAEU technical regulations without scan copies of relevant documents.

The Letter by The Federal Service for Hydrometeorology and Environmental Monitoring dated August 16, 2018 No. 20-44/282 "On sending Temporary recommendations "Background concentrations of hazardous substances (pollutants) to urban and rural settlements where there are no regular observations over ambient air contamination" for 2019-2023"

For a period 2019-2023 The Federal Service for Hydrometeorology and Environmental Monitoring has developed temporary recommendations on establishing background concentrations of pollutants in atmospheric air for urban and rural settlements where observations over atmospheric air contamination are not performed regularly. The recommendations are developed basing on analysis and generalization of data collected in towns with their population size not exceeding 100 thousand people.

Following the implementation of "Methods to calculate dispersion adverse substances (pollutants) emissions in the atmosphere" since January 01, 2018 approved by the Order by the RF Ministry for Natural Resources dated June 06, 2017 No. 273, the recommendations contain a table with values of longterm average concentrations of adverse substances (pollutants) for towns with the above-mentioned population size.

The recommendations also contain a typical reference form applied to inform about background concentrations of pollutants. 